UNIVERSIDADE DE SÃO PAULO

FACULDADE DE MEDICINA DE RIBEIRÃO PRETO

DEPARTAMENTO DE BIOQUÍMICA E IMUNOLOGIA

Karoline Maria Vieira Nogueira

Identificação e caracterização de novos transportadores de açúcar potencialmente envolvidos no processo de degradação da biomassa lignocelulósica em Trichoderma reese $i$

Ribeirão Preto 
Karoline Maria Vieira Nogueira

Identificação e caracterização de novos transportadores de açúcar potencialmente envolvidos no processo de degradação da biomassa lignocelulósica em Trichoderma reesei

Dissertação apresentada à Faculdade de Medicina de Ribeirão Preto da Universidade de São Paulo para obtenção do título de Doutora em Ciências.

Área de concentração: Bioquímica

Orientador: Prof. Dr. Roberto do Nascimento Silva

Ribeirão Preto 
AUTORIZO A REPRODUÇÃO E DIVULGAÇÃO TOTAL OU PARCIAL DESTE TRABALHO, POR QUALQUER MEIO CONVENCIONAL OU ELETRÔNICO, PARA FINS DE ESTUDO E PESQUISA, DESDE QUE CITADA A FONTE.

FICHA CATALOGRÁFICA

Nogueira, Karoline Maria Vieira

Identificação e caracterização de novos transportadores de açúcar potencialmente envolvidos no processo de degradação da biomassa lignocelulósica em Trichoderma reesei.

128p. il., $30 \mathrm{~cm}$.

Tese apresentada à Faculdade de Medicina de Ribeirão Preto da Universidade de São Paulo para obtenção do título de Doutora em Ciências.

Área de concentração: Bioquímica

Orientador: Prof. Dr. Roberto do Nascimento Silva

1. Trichoderma reesei. 2. Transportadores de açúcar. 3. Biomassa lignocelulósica. 4. Saccharomyces cerevisiae. 5.Biocombustíveis. 


\section{FOLHA DE APROVAÇÃo}

Nogueira, K. M. V.

Identificação e caracterização de novos transportadores de açúcar potencialmente envolvidos no processo de degradação da biomassa lignocelulósica em Trichoderma reesei.

Tese apresentada à Faculdade de Medicina de Ribeirão Preto da Universidade de São Paulo para obtenção do título de Doutora em Ciências. Área de concentração: Bioquímica

Aprovada em:

Banca Examinadora

Prof. Dr.

Instituição:

Julgamento:

Assinatura:

Prof. Dr.

Instituição:

Julgamento:

Assinatura:

Prof. Dr.

Instituição:

Julgamento:

Assinatura:

Prof. Dr.

Instituição:

Julgamento:

Assinatura: 


\section{DEDICO}

Aos meus pais, Rose e Eloi.

Nós conseguimos concluir mais uma etapa! Nós conseguimos e foi como sempre, juntos! Sem vocês eu não conseguiria. Obrigada meus amores, eu sei o quanto trabalharam e lutaram para isso. Obrigada por seguirem comigo, sempre com tanta fé. A minha gratidão e amor por vocês não tem fim!

Ao Luiz.

À você que é meu apoio e alegria diária. Você quem esteve comigo em todos os dias do Doutorado, quem mudou de país e de vida pra me acompanhar e quem segue, sempre junto comigo, como companheiro de vida! Gratidão amor, por ter você como marido e amigo. Amo você. 


\section{AGRADECIMENTOS}

À todas as pessoas que estiveram presente durante os quatro anos do meu Doutorado e a aquelas que fizeram parte, mesmo que de forma passageira, o meu muito obrigada!

Ao Prof. Dr. Roberto, meu orientador, obrigada por tanto! Tanto aprendizado, tantos desafios, tantas conversas. Obrigada por me acolher em seu laboratório e no grupo durante os 6 anos da minha caminhada acadêmica, para enfim, concluir mais uma etapa importante da minha vida. Obrigada por me deixar fazer parte dessa família tão linda que é o LBM e por prezar pela nossa união. Unidos sempre seremos mais fortes!

À minhas irmãs, Josi, Raquel e Heloisa a ao meu sobrinho, Roger. O meu amor por vocês me alegra e me enche de forças todos os dias. Obrigada por, mesmo à distância, deixarem minha vida sempre feliz, só de saber que tenho vocês como família. Aos meus cunhados, obrigada pelo carinho e pelos momentos em família.

Aos queridos do LBM, Alinne, Mari. Z, Vanessa, David, Cláudia, Wellington, Douglas, Marcela, Zú, Silvia e Lili, obrigada pelas risadas, conversas, companhia e pelo trabalho que realizamos juntos durante esses anos. Quando trabalhamos com pessoas como vocês, a vida fica mais feliz!

À Maricota e Renato. Vocês estiveram comigo durante todos os anos de LBM, e me ajudaram sempre, em tudo. Que nossa amizade tenha vida longa, e que vocês saibam o quanto sou feliz por ter vocês por perto. Obrigada!

À Amanda e Diego, Flávia e Fabinho. Obrigada pela amizade, apoio e alegrias durante todos esses anos. Que estejamos sempre juntos, comemorando a vida e a amizade. Com vocês a vida é mais feliz!

À Andreia e Felipe. Vocês são alegria e positividade! Obrigada por me transmitir isso sempre que nos encontramos. Obrigada pela amizade e pelo companheirismo.

À Camila e Felipe. Obrigada pela companhia e pelas conversas. É sempre bom quando vocês 
estão por perto.

Ao Carlos e Gildo. Meus queridos, uma das melhores surpresas que 2017/2018 me proporcionou foi a amizade de vocês. Obrigada por terem feito parte desse ano lindo que passamos na Austrália, por terem sido nosso apoio e por ter trazido tanta alegria pra nós. Que nossa amizade tenha vida longa!

Às minhas amigas Jô, Naiara, Camila, Lili e Paula. Obrigada por toda a alegria que vocês me proporcionam e pela amizade.

À Anusha, minha querida amiga e companheira de laboratório na Macquarie University. Tive a grande oportunidade de trabalhar com ela, uma pessoa que me enriqueceu tanto, trazendo não só ensinamentos no laboratório, mas de vida. Muito obrigada!

Aos queridos que estão ou já passaram pelo Departamento de Bioquímica. Sarah, André, Ana, Pri, Deisy, Geisa e Matheus. Obrigada pelas conversas descontraídas que sempre deixam o dia melhor.

Ao Dr. Fausto Almeida, Dr. Gustavo Goldman, Dra. Thaila dos Reis, Dra. Carem Glades, Dr. Ardeshir Amirkhani, Dr. Matthew Mackey, Dra. Helena Nevalainen, Dr. Marck P Molloy e Dr. Karthik Kamath. Obrigada pela colaboração, conhecimento compartilhado e pelas sugestões no decorrer deste trabalho.

Aos funcionários do Departamento de Bioquímica e Imunologia. Obrigada por me auxiliarem sempre que necessário.

À FAPESP e CAPES pela bolsa de doutorado e auxílio financeiro na execução desse projeto (Processos FAPESP 2015/09553-8 e 2017/08446-9). O presente trabalho foi realizado com apoio da Coordenação de Aperfeiçoamento de Pessoal de Nível Superior - Brasil (CAPES) Código de Financiamento 001. 
"Na verdade, o tempo nos toma o tempo que a vida nos reserva.

Mas é no tempo que temos tempo para buscar aquilo que, em nossa mente, a vontade de conquistar algo conserva.

Toda conquista é fruto, com certeza, de muito esforço e muito estudo para se chegar a uma conclusão.

Concluir significa alcançar uma meta, mas outras surgirão.

É sempre bom concluir.

Faz bem para o nosso conhecimento, sem exceção.

Como num toque de mágica, em tudo que conquistamos, a alegria se faz presente.

E como uma anestesia, tira a dor que a luta muitas vezes pode nos proporcionar.

Estamos pois prontos, para na vida, novos desafios buscar." 


\section{RESUMO}

NOGUEIRA, K. M. V. Identificação e caracterização de novos transportadores de açúcar potencialmente envolvidos no processo de degradação da biomassa lignocelulósica em Trichoderma reesei, 2019. 128f. Tese de Doutorado - Faculdade de Medicina de Ribeirão Preto, Universidade de São Paulo.

O fungo Trichoderma reesei apresenta uma surpreendente capacidade de produzir e secretar celulases e hemicelulases, sendo o fungo industrial mais importante na produção dessas enzimas que são utilizadas, dentre outros fins, na indústria de biocombustíveis, tal como o bioetanol. Durante o processo natural de degradação da biomassa lignocelulósica, uma série de transportadores de açúcar, com diferentes afinidades frente a um substrato, são empregados pelo fungo. A identificação e caracterização destes transportadores de açúcar pode gerar uma melhor compreensão sobre a função que estes componentes exercem no sistema de transporte de açúcares e os mecanismos moleculares nos quais estas proteínas estão envolvidas na célula. Esse trabalho tem como objetivo a identificação e caracterização de novos transportadores de açúcar potencialmente envolvidos na degradação da biomassa. Para isso, diferentes ferramentas foram empregadas. No capítulo I, é descrito a caracterização de um transportador de açúcar, Tr69957, previamente identificado por nosso grupo de pesquisa através de análises in silico de dados de RNA-seq. A deleção gênica de Tr69957 em T. reesei e análises funcionais ex vivo, através da complementação gênica do transportador em uma linhagem de Saccharomyces cerevisiae (EBY. VW4000), sugere a função deste transportador no carreamento de manose, celobiose e xilose. Além disso, a deleção do transportador afetou o perfil de expressão de genes que codificam para celulases em $T$. reesei. No capítulo II, uma revisão contendo resultados de pesquisa provenientes do nosso grupo: Laboratório de Biotecnologia Molecular, apresenta os principais dados sobre o envolvimento de transportadores de açúcar durante o processo de degradação da biomassa lignocelulósica. Por fim, no capítulo III, através de análises proteômicas, 14 transportadores de açúcar foram identificados durante o cultivo de $T$. reesei em presença de celulose microcristalina e glicerol. A identificação desses transportadores de açúcar em presença de celulose demonstra potencial função biológica durante o processo de degradação.

Palavras chave: 1. Trichoderma reesei. 2. Transportadores de açúcar. 3. Biomassa Lignocelulósica, 4. Saccharomyces cerevisiae. 5.Biocombustíveis. 


\begin{abstract}
NOGUEIRA, K. M. V. Identification and characterization of novel sugar transporters potentially involved in lignocellulosic biomass degradation process in Trichoderma reesei, 2019. 128f. Tese de Doutorado - Faculdade de Medicina de Ribeirão Preto, Universidade de São Paulo.

The fungus Trichoderma reesei presents a surprising capacity to produce and secrete cellulases and hemicellulases, being the most important industrial fungus in the production of these enzymes that are used, among other purposes, in the industry of biofuels, such as bioethanol. During the natural process of degradation of lignocellulosic biomass, the fungus employs several sugar transporters with different affinities to a substrate. The identification and characterization of these sugar transporters can generate insights into the role of these components in the sugar transport system and the molecular mechanisms in which these proteins are involved in the cell. This work aims at the identification and characterization of new sugar transporters potentially involved in the degradation of biomass. For this, different tools were employed. In Chapter I, the characterization of a sugar transporter, Tr69957, previously identified by our research group through in silico RNA-seq data analysis, is described. Gene deletion of Tr69957 in T. reesei and functional ex vivo analyzes, through $S$. cerevisiae EBY.VW4000 strain complemented with candidate sugar transporter gene, suggests the role of this transporter in mannose, cellobiose and xylose uptake. In addition, transporter deletion affected the expression profile of cellulases encoding genes in T. reesei. In chapter II, a review containing research results from our group: Laboratory of Molecular Biotechnology presents the main data on the involvement of sugar transporters during the process of degradation of lignocellulosic biomass. Finally, in chapter III, through proteomic analyzes, 14 sugar transporters were identified during the growth of $T$. reesei in microcrystalline cellulose and glycerol. The identification of these sugar transporters in presence of cellulose demonstrates potential biological function during the degradation process.
\end{abstract}

Key words: 1. Trichoderma reesei. 2. Sugar transporters. 3. Lignocellulosic biomass. 4. Saccharomyces cerevisiae. 5.Biofuels. 


\section{SUMÁRIO}

1. Introdução 13

$\begin{array}{ll}\text { 1.1 Etanol de segunda geração no Brasil } & 13\end{array}$

2. Revisão bibliográfica 15

$\begin{array}{ll}2.1 \text { Biomassa lignocelulósica } & 15\end{array}$

2.2 Trichoderma reesei e a degradação da biomassa lignocelulósica 17

2.3 Importância dos transportadores de açúcar no processo de regulação da $\quad 21$ expressão de CAZymes

2.4 Relevância do estudo dos transportadores de açúcar de Trichoderma reesei 24 para a produção de etanol $2 \mathrm{G}$

2.5. Ferramentas para identificação e caracterização de transportadores de açúcar

2.5.1 Transcriptômica e proteômica

2.5.2 Ferramentas de bioinformática

2.5.3 Ancoragem molecular (ou docking molecular) 30

2.5.4 Validação funcional 31

2.5 Família de transportadores com função no transporte de açúcares: MFS 33

(Major Facilitator Superfamily) permease

3. Objetivos 36

4. Material e Métodos/Resultados 38

4.1 Capítulo I 38

4.2 Capítulo II $\quad 58$

$\begin{array}{ll}4.3 \text { Capítulo III } & 78\end{array}$

$\begin{array}{lr}\text { 5. Considerações finais } & 102\end{array}$

$\begin{array}{lr}\text { 6. Conclusão } & 106\end{array}$

$\begin{array}{lc}\text { 7. Perspectivas } & 108\end{array}$

$\begin{array}{ll}\text { 8. Referências } & 110\end{array}$

9. Apêndices 118

$\begin{array}{lr}\text { 10. Anexo de publicações } & 128\end{array}$ 
Introdução

\section{Introdução}

Nos últimos anos, muito se tem discutido a respeito de novas formas de energia que reduzam os impactos negativos ao ambiente ocasionados pela queima de combustíveis fósseis. Diante desse contexto, a produção de biocombustíveis através da utilização da biomassa renovável (etanol de secunda geração, etanol 2G) é umas das principais alternativas para se contornar esse problema (SAINI; SAINI; TEWARI, 2015; ZABED et al., 2016).

A biomassa lignocelulósica (BLC) é, basicamente, constituída por celulose, hemicelulose e lignina. Na rota bioquímica de produção de etanol $2 \mathrm{G}$, a biomassa é submetida a um pré-tratamento, com o objetivo de desorganizar a estrutura do material lignocelulósico; a processos de hidrólise, no qual polímeros de celulose e hemicelulose são convertidos em açúcares simples; e de fermentação, através do uso de leveduras que convertem os açúcares provenientes da hidrólise da biomassa em etanol (SAINI; SAINI; TEWARI, 2015).

Apesar de intensos investimentos e pesquisas na área, o processo de obtenção de etanol $2 \mathrm{G}$ apresenta diferentes gargalos que dificultam o alcance da viabilidade econômica desse combustível (PAULINO et al., 2018).

Perante este contexto, essa tese é focada na identificação e caracterização de transportadores essenciais no transporte de açúcares provenientes da BLC. Com esse estudo, pretende-se promover conhecimento necessário para o desenvolvimento de novas tecnologias que visem à otimização do processo de obtenção do bioetanol e à redução do custo desse biocombustível, tornando-o mais acessível à população.

\subsection{Etanol de segunda geração no Brasil}

A crescente demanda mundial por energia, em conjunto com a limitação dos recursos petrolíferos e o impacto ambiental causado pelo uso destes, tem impulsionado a busca por fontes de energia renovável. Nesse contexto, os biocombustíveis têm sido alvo de atenção crescente nas últimas décadas (SAINI; SAINI; TEWARI, 2015; ZABED et al., 2017).

No Brasil, no começo dos anos 70, quando a crise do óleo triplicou o valor do custo da importação desse produto, o governo brasileiro lançou o Programa Brasileiro de Combustíveis a Álcool (Proálcool), que ofereceu um plano financeiro em que se ampliava a área de plantio de cana-de-açúcar e a construção de novas usinas para o seu processamento. Esse programa incentivou a produção de etanol a partir da cana-de-açúcar e estabeleceu uma lei que exigia a mistura de $20 \%$ do teor de etanol com a gasolina no Brasil (PAULINO et al., 2018). 
Introdução

Produzido a partir da biomassa renovável, o etanol de primeira geração (1G) transformou-se em um importante adjunto moderno do petróleo e a participação das energias renováveis na matriz energética brasileira manteve-se entre as mais altas do mundo (EPEBALANÇO ENERGÉTICO NACIONAL, 2014).

Na contemporaneidade, o Brasil é o segundo maior produtor e exportador de etanol da cana-de-açúcar e grande parte do abastecimento de combustível do país é produzido através de fontes de energia renováveis (LEITE et al., 2009; PAULINO et al., 2018).

Por mais de 40 anos, o Brasil produz etanol combustível em escala industrial. É importante salientar que a produção de etanol ocorre por meio da fermentação da sacarose do suco da cana para produzir o denominado etanol de primeira geração (1G) (PAULINO et al., 2018; ZABED et al., 2017). Durante a etapa de processamento da cana-de-açúcar, uma quantidade elevada de material lignocelulósico, como o bagaço e a palha de cana-de-açúcar, é gerado. Esse material lignocelulósico acaba sendo utilizado como combustível em caldeiras para fornecer energia para o processo e/ou vender o excedente de energia gerada para a rede, enquanto que a maior parte da palha e bagaço são rejeitados ou queimados (ZABED et al., 2016).

A possibilidade de utilização da biomassa lignocelulósica - que compreende resíduos agroindustriais como o bagaço e a palha de cana-de-açúcar - potencialmente rica em substratos que poderão ser convertidos em etanol - há décadas, tem impulsionado pesquisas no desenvolvimento do etanol de segunda geração (2G). Com a comercialização de etanol de segunda geração (2G), o Brasil poderia aumentar a produção daquele em, aproximadamente, $40 \%$ (BORIN et al., 2015), atendendo assim ao interesse nacional de aumentar a produtividade desse combustível sem aumentar, nas mesmas proporções, a área cultivada (LEITE et al., 2009).

Apesar de diversas empresas no setor privado estarem investindo em produtos que visam reduzir custos e aumentar os rendimentos na produção de etanol a partir de resíduos agrícolas, em 2017 a produção de etanol 2G, no Brasil, ainda era considerada muito baixa. A demora em alcançar a viabilidade econômica tem afastado investidores, no entanto algumas empresas ainda continuam na busca. Duas usinas voltadas à produção de etanol de segunda geração - uma da Granbio, localizada em São Miguel dos Campos, em Alagoas, e a outra da Raízen, situada em Piracicaba, no interior de São Paulo - possuíam a capacidade de produção de pouco mais de 100 milhões de litros por ano. No entanto, as duas usinas produziam menos da metade dessa capacidade. Em 2018, utilizando como matéria-prima resíduos da cana-de- 
Introdução

açúcar, como bagaço, que sobram da produção de etanol $1 \mathrm{G}$ e superando obstáculos no processo de produção, ambas plantas industriais foram consideradas mais próximas de atingir um estágio de eficiência tecnológica e viabilidade econômica (MARQUES, 2018).

Nos últimos anos, o Brasil tem aumentado o desenvolvimento de novas tecnologias, favorecendo a produção de etanol no país, entretanto, a melhoria da produção de etanol $2 \mathrm{G}$ continua sendo um desafio a ser superado. $\mathrm{O}$ custo do processo de produção de etanol $2 \mathrm{G}$ ainda é alto quando comparado ao etanol 1G (MARQUES, 2018). Para ser economicamente mais viável, diferentes obstáculos durante o processo devem ser superados, o que aponta a necessidade de mais pesquisas e investimentos na área.

\section{Revisão Bibliográfica}

\subsection{Biomassa lignocelulósica}

A biomassa lignocelulósica abrange resíduos agrícolas e agroindustriais, sendo estes abundantes, renováveis e fontes de energia de baixo custo. Esses resíduos incluem uma variedade de materiais, tais como, bagaço da cana-de- açúcar, resíduos de papel, palhas, e cascas de cereais como arroz, trigo, milho, sorgo, cevada (SAINI; SAINI; TEWARI, 2015). No Brasil, o bagaço da cana-de-açúcar se destaca como substrato para produção de etanol 2G por ser considerada a fonte de biomassa lignocelulósica mais abundante dentre as atividades agroindustriais (BRIENZO, 2010).

De forma geral, os principais constituintes da biomassa lignocelulósica são celulose, hemicelulose e lignina (Figura 1). A celulose é um polímero linear constituído por repetidas unidades de celobiose (duas moléculas D-glicose conectadas por ligações glicosídicas $\beta-1 \rightarrow$ 4). O polímero de celulose apresenta duas estruturas específicas: uma região cristalina rígida e uma zona amorfa (ISIKGOR; BECER, 2015; KUMAR; GAUTAM; DUTT, 2016)

Ao contrário da celulose, a hemicelulose apresenta uma propriedade mais amorfa. A composição precisa da hemicelulose depende das espécies vegetais e tecidos. A hemicelulose é composta por heteropolímeros que incluem: xilanas (D-xilose ligadas por ligações glicosídicas $\beta-1 \rightarrow 4$ ), mananas (D-manose ligadas por ligações glicosídicas $\beta-1 \rightarrow 4$ ), xiloglucanas (D-glicose ligadas por ligações glicosídicas $\beta-1 \rightarrow 4$ ). As cadeias principais do heteropolímero podem apresentar diversos tipos de ramificações, constituindo altos níveis de complexidade (SCHELLER; ULVSKOV, 2010). 
Introdução

A lignina é um heteropolímero aromático complexo relativamente hidrofóbico e irregular. Esse heteropolímero é derivado de três precursores primários: álcool trans-p-cumarílico, trans-coniferílico e álcool trans-sinapilico. Esse componente mantém a estrutura da biomassa conectada, proporcionando-lhe rigidez e resistência a ataques externos (microbiológicos e mecânicos) (RALPH et al., 2018).

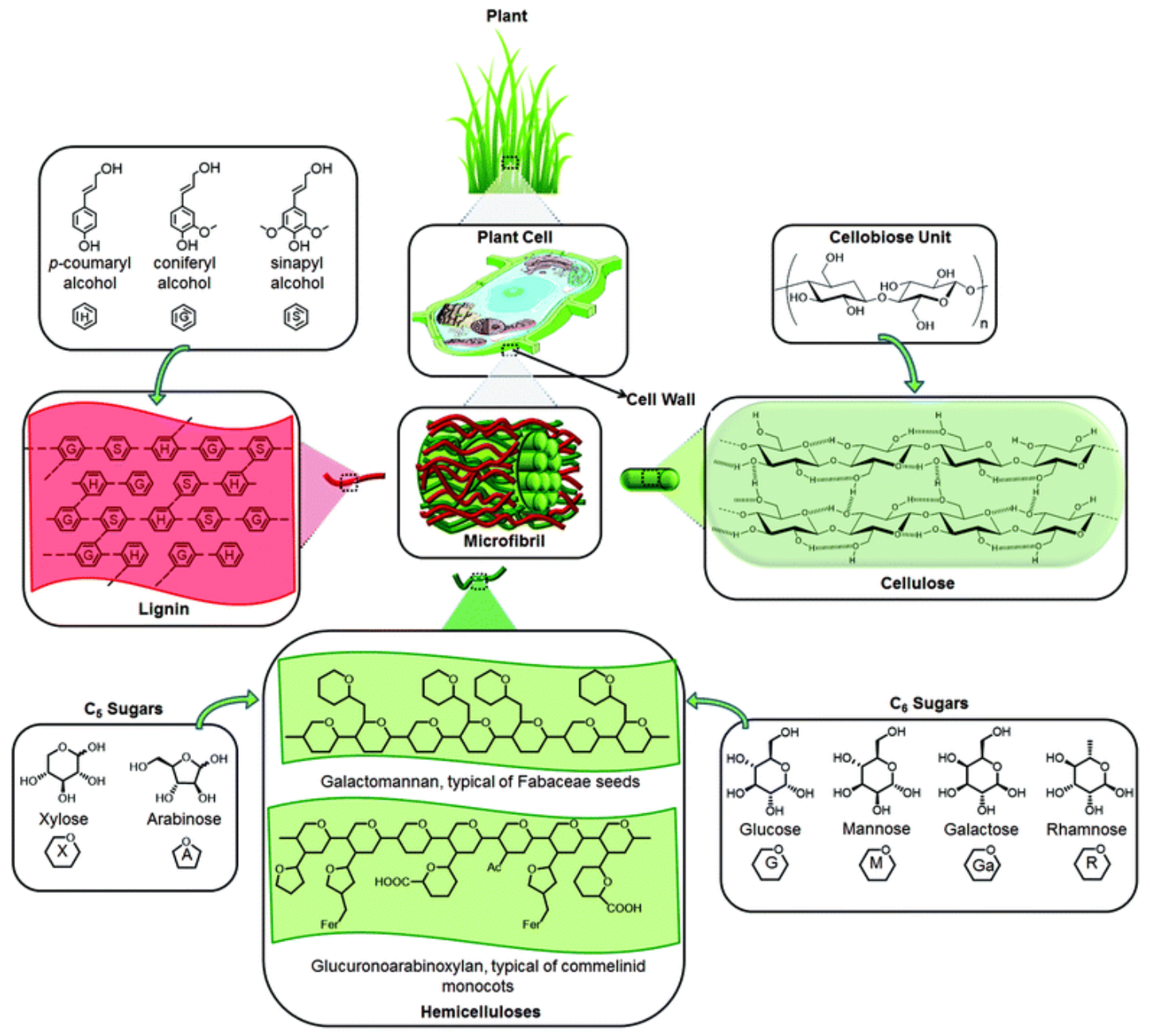

Figura 1. Os principais componentes e estrutura da lignocelulose (ISIKGOR; BECER, 2015). 
Introdução

\subsection{T. reesei e a degradação da biomassa lignocelulósica}

Fungos do gênero Trichoderma são alguns dos mais estudados dentre os fungos filamentosos devido ao seu grande potencial de aplicação do ponto de vista industrial e biotecnológico (Samuels, 1996). Fungos desse gênero podem ser encontrados em quase todos os tipos de solos e ambientes naturais, principalmente, naqueles contendo matéria orgânica (SCHMOLL; SCHUSTER, 2010).

A espécie T. reesei foi identificada pela primeira vez durante a Segunda Guerra Mundial devido à deterioração de tecidos de algodão pertencentes ao exército dos Estados Unidos nas Ilhas Salomão, onde foi isolada (PETERSON; NEVALAINEN, 2012). Conhecida como uma das produtoras mais eficientes de enzimas celulolíticas e xilanolíticas (DASHTBAN; SCHRAFT; QIN, 2009a), T. reesei está entre as cepas mais estudadas para a degradação da biomassa lignocelulósica, sendo comercialmente explorado pela eficiência na produção dessas enzima (PAULA et al., 2018)

O uso desse fungo como microrganismo de estudo representa um modelo adequado para a degradação da biomassa lignocelulósica, uma vez que elefornece enzimas ativas de carboidratos (CAZymes) através de um processo natural de degradação dessa biomassa (ZNAMEROSKI; GLASS, 2013). Esse fungo produz um conjunto de enzimas que atuam de modo sinérgico para hidrolisar a celulose cristalina a oligossacarídeos menores e, finalmente, à glicose (ILMÉN et al., 1997). As enzimas do complexo celulolítico são hidrolases que clivam as ligações glicosídicas do polímero de celulose. De acordo com o local em que atuam, é possível classificar essas enzimas em pelo menos três grandes grupos: as endoglicanases, que clivam as ligações internas da fibra de celulose; as exoglicanases, que atuam na região externa da celulose; e as $\beta$-glicosidases, que hidrolisam oligossacarídeos solúveis em moléculas de glicose (Figura 2) (JUHÁSZ et al., 2005) .

As endoglicanases (EC 3.3.1.4) clivam as ligações glicosídicas internas da celulose de modo aleatório, liberando oligossacarídeos de vários comprimentos e, consequentemente, novas cadeias finais. $\mathrm{O}$ fungo $T$. reesei produz pelo menos oito endoglicanases, que são denominadas EGI/CEL7B, EGII/CEL5A, EGIII/CEL12A, EGIV/CEL61A (reclassificada como polissacarídeo monooxigenase), EGV/CEL45A, CEL74A, CEL61B E CEL5B (DASHTBAN; SCHRAFT; QIN, 2009b; KUBICEK et al., 2009).

As exoglicanases (EC 3.2.1.91) ou celobiohidrolases $(\mathrm{CBH})$ hidrolisam preferencialmente as ligações $\beta$-1,4-glicosídicas das extremidades da cadeia de celulose, produzindo como produto principal a celobiose. Em T. reesei foram identificadas duas 
Introdução

diferentes celobiohidrolases. Uma delas, denominada CBHII/Cel6A, atua a partir da extremidade não-redutora e a outra, CBHI/Cel7A, na extremidade redutora da celulose, resultando em uma degradação celulolítica bastante eficiente. As exoglicanases geralmente sofrem inibição pelo seu produto de hidrólise, a celobiose, que atua como um inibidor competitivo, limitando a capacidade das enzimas em degradar todas as moléculas de celulose de um sistema (DASHTBAN; SCHRAFT; QIN, 2009b; PAULA et al., 2018)

As $\beta$-glicosidases (EC 3.2.1.21) hidrolisam celobiose e oligossacarídeos solúveis em glicose. Em T. reesei, são descritos pelo menos sete tipos diferentes de $\beta$-glicosidases, sendo elas CEL1A/BGL2, CEL1B, CEL3A/BGL1, CEL3B, CEL3C, CEL3D e CEL3E. Quando a atividade das $\beta$-glicosidades está em baixa, pode haver um acúmulo de celobiose, que é um inibidor da atividade das celobiohidrolases (GUO et al., 2016).

Outro grupo de proteínas relacionadas ao processo de conversão da biomassa são as glicosil hidrolases da família 61 (GH61) esoleninas. A atuação dessas proteínas tornam o polímero de celulose mais acessível à ação das celulases tradicionais (QUINLAN et al., 2011).

Por apresentar uma estrutura heterogênea, a degradação da hemicelulose requer um amplo repertório enzimático. Endo-1,4- $\beta$-D-xilanases e $\beta$-xilosidases são enzimas necessárias na hidrólise de xilana, enquanto que para hidrólise de manana, três enzimas são requeridas: $\beta$ mananase, $\beta$-glicosidase e $\beta$-manosidase. Para clivar os diferentes grupos laterais da cadeia principal do heteropolímero, são necessárias diversas enzimas, incluindo acetil-xilana esterases, acetil esterases, $\alpha$-xilosidases, $\alpha$-galactosidases, $\alpha$-L-arabinofuranosidases e $\alpha$ glucuronidases (SAHA, 2003) . É descrito que genoma de T. reesei codifica pelo menos uma $\beta$-mananase GH5 (MANI) (TV; TELEMAN, 1997)) e quatro xilanases (XYNI, XYNIII, XYNII e XYNIV) pertencentes às famílias GH30, GH11 e GH10 (HEROLD et al., 2013) 


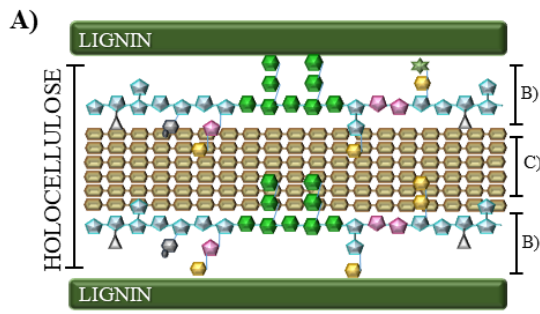

B) HEMICELLULOSE
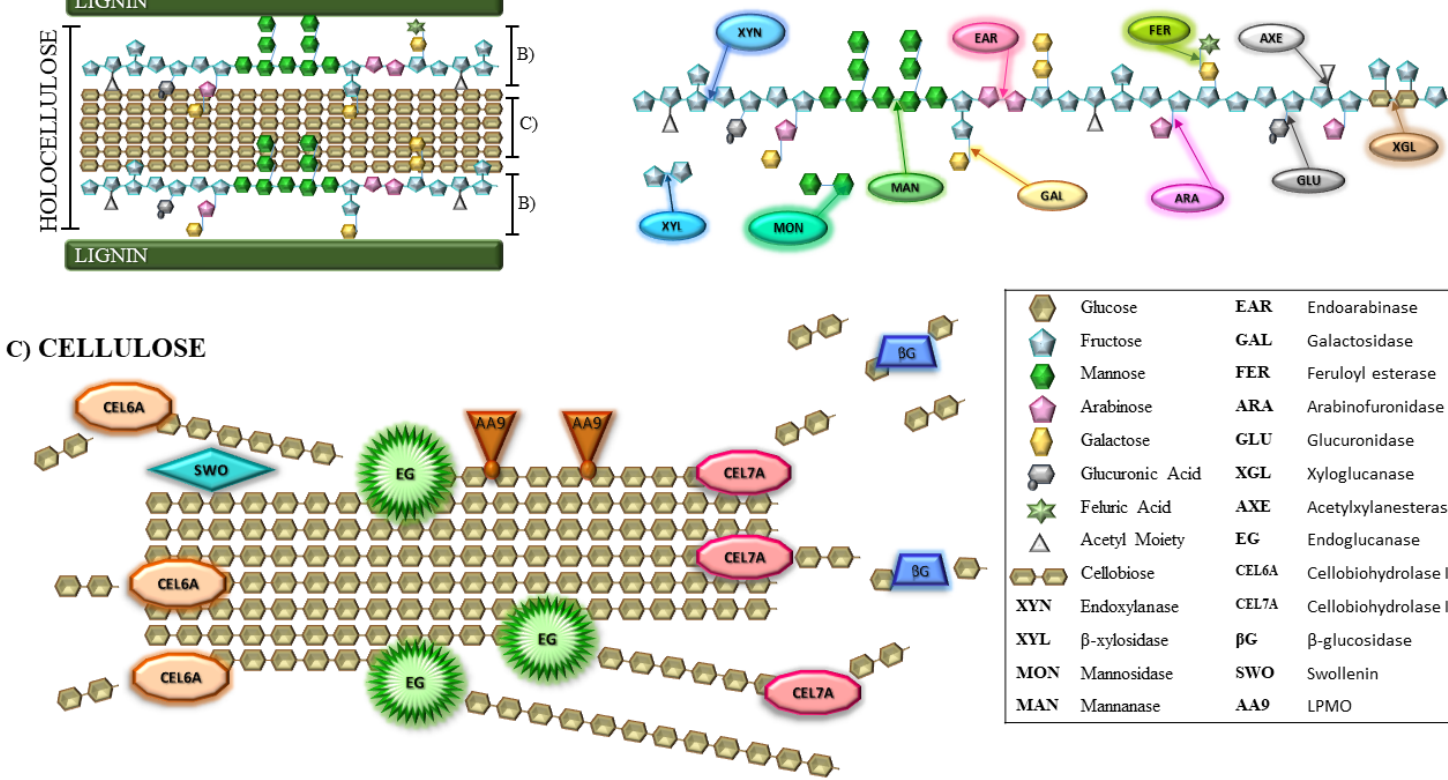

\begin{tabular}{|c|c|c|c|}
\hline 0 & Glucose & EAR & Endoarabinase \\
\hline 0 & Fructose & GAL & Galactosidase \\
\hline & Mannose & FER & Feruloyl esterase \\
\hline 0 & Arabinose & ARA & Arabinofuronidase \\
\hline 0 & Galactose & GLU & Glucuronidase \\
\hline 8 & Glucuronic Acid & XGL & Xyloglucanase \\
\hline 际 & Feluric Acid & AXE & Acetylxylanesterase \\
\hline$\triangle$ & Acetyl Moiety & EG & Endoglucanase \\
\hline घ曰 & Cellobiose & CEL6A & Cellobiohydrolase II \\
\hline XYN & Endoxylanase & CEL $7 \mathrm{~A}$ & Cellobiohydrolase I \\
\hline XYL & $\beta$-xylosidase & $\beta G$ & $\beta$-glucosidase \\
\hline MON & Mannosidase & swo & Swollenin \\
\hline MAN & Mannanase & AA9 & LPMO \\
\hline
\end{tabular}

Figura 2. Regulação global da expressão de holocelulases em T. reesei. (a) A estrutura esquemática da biomassa lignocelulósica, que é constituída por lignina e holocelulose, composta de hemicelulose e celulose. Todas as cadeias são desenhadas da extremidade redutora (esquerda) para a extremidade não redutora (direita). (b) As enzimas que atacam a hemicelulose atuam em sinergia para hidrolisá-la eficientemente e promover uma área superficial mais acessível na celulose, para aumentar a atividade de celulases. (c) A degradação enzimática da celulose: EG atua clivando em regiões amorfas da cadeia, enquanto CEL6A e CEL7A clivam o polímero nas extremidades não redutoras e redutoras, respectivamente. Os oligossacáridos resultantes desta clivagem são então quebrados em monossacáridos pela $\beta$-glicosidase, sendo então metabolizados diretamente pelo organismo. A SWO expande a cadeia celulolítica para melhorar a acessibilidade de celulases a esta, e a AA9 funciona através do metabolismo oxidativo dependente de íon metálico bivalente. Fonte: (De PAULA et al., 2018)

Toda essa maquinaria enzimática descrita é regulada por uma sofisticada rede de regulação que abrange moléculas indutoras, repressoras e fatores de transcrição. A regulação dos principais genes da celulase ocorre de forma coordenada de acordo com a fonte de carbono disponível (Figura 3).

A expressão de genes de celulases pode ser induzida por celulose e outros açúcares como celobiose e soforose (SCHMOLL; KUBICEK, 2003), enquanto que, fontes de carbono prontamente metabolizáveis como glicose e frutose reprimem a expressãodeles. Soforose é formada a partir de celobiose, através de uma reação de transglicolisilação mediada por $\beta$ glicosidase (STERNBERG; MANDELS, 1979a).

Atualmente pelo menos dez fatores transcricionais são conhecidos por estarem envolvidos durante a regulação da desconstrução da celulose em $T$. reesei; os reguladores positivos XYR1, ACEII, ACEIII, LAE1, VEL1, BglR e o complexo HAP2 / 3/5, e os repressores CRE1, RCE1 e ACE1 (HÄKKINEN et al., 2012; PAULA et al., 2018; PORTNOY et al., 2011). 
Introdução

Além de atuar durante o processo de ativação dos genes da celulase, alguns fatores de transcrição, como o XYR1, também podem regular os genes hemicelulolíticos, alguns fatores de transcrição e transportadores (CASTRO et al., 2014).

Muitos dos genes que codificam para hemicelulases são induzidos com celulose, xilana, xilobiose, L -arabinose, L-arabitol e sophorose. Baixas concentrações de D-xilose, produto de degradação de xilana, induz a expressão do gene da xilanase, enquanto que altas concentrações têm um efeito repressor (HEROLD et al., 2013).

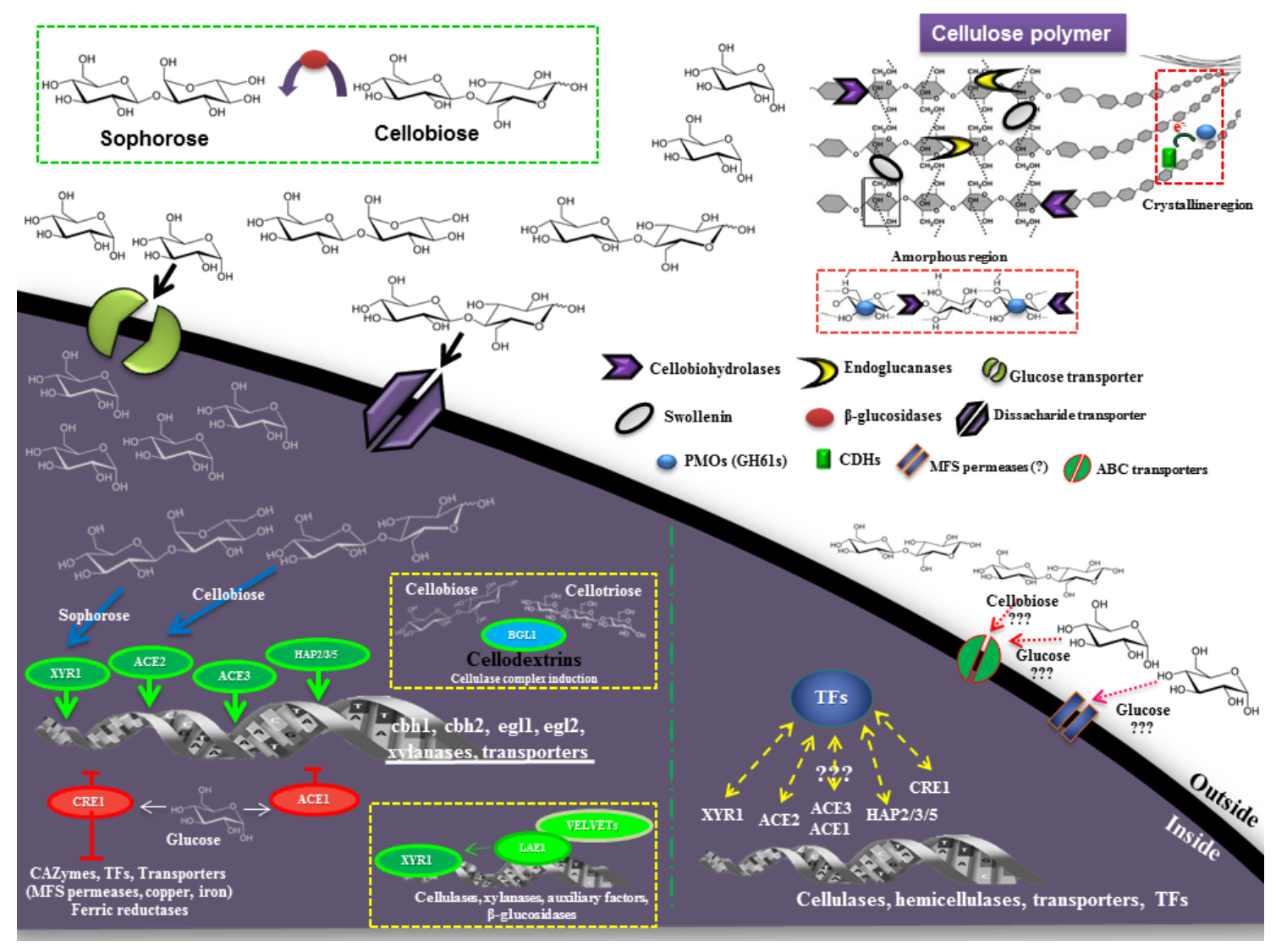

Figura 3. Visão geral do regulamento global da expressão de celulases em $T$. reesei. Esta figura mostra os processos que se espera que estejam envolvidos na regulação enzimas lignocelulósicas em T. reesei. A expressão das enzimas envolvidas na degradação do material é controlada pelos principais fatores de transcrição (TFs): XYR1, ACE1, ACE2, ACE3, CRE1 e Complexo HAP2 / 3/5. Adicionalmente, uma suposta proteína, metiltransferase LAE1 e VELVET mostrou-se importante na expressão do gene da celulase. As setas pontilhadas indicam áreas a serem melhor investigadas. Neste ponto, os TFs ainda não caracterizados podem ativar ou reprimir (diretamente ou indiretamente) os TFs principais envolvidos com a expressão da celulase. Além disso, estes FTs podem regular a expressão da MFS (do inglês Major Facilitator Superfamily) permeases e transportadores $\mathrm{ABC}$ (do inglés ATP-binding cassette) que, por sua vez, são responsáveis pela absorção de açúcar em resposta a diferentes fontes de carbono (GUPTA et al., 2016)

Apesar da regulação dos genes das celulases em T. reesei estar bem descrita na literatura, a forma como o fungo reconhece o seu substrato e ativa a transcrição de genes que 
Introdução

codificam transportadores e determinados fatores de transcrição, que culminam na produção de enzimas hidrolíticas ainda não está claramente elucidada.

\subsection{Importância dos transportadores de açúcar no processo de regulação da expressão de CAZymes}

A adequada percepção da presença do substrato pelo fungo é essencial para que toda a cascata de indução de enzimas celulolíticas seja iniciada. A celulose é considerada um indutor da expressão de genes que codificam para celulases requeridas no processo de degradação da BML por fungos filamentosos. No entanto, como esse polímero insolúvel, naturalmente indutor, não pode ser transportado para o interior da célula fúngica, presume-se que oligossacarídeos e seus derivados, liberados da hidrólise desse polímero, funcionam como as reais moléculas desencadeadoras da indução enzimática (GLASS et al., 2013).

Acredita-se que em $T$. reesei ocorra um mecanismo baseado na presença de baixos níveis de celulase no fungo. Dessa forma, essa atividade basal de celulase seria a responsável pela liberação de oligossacarídeos a partir da hidrólise da celulose que, posteriormente, poderiam entrar na célula e desencadear a expressão de celulases (CARLE-URIOSTE et al., 1997) Especificamente, tanto celobiose, o principal produto final solúvel da hidrólise da celulose, quanto seu derivado, a soforose, demonstraram induzir a expressão gênica e atividade celulolítica em T. reesei (MANDELS; REESE, 1959; STERNBERG; MANDELS, 1979b).

Além dos transportadores de açúcar serem os responsáveis por carrear, do ambiente extracelular para o interior da célula, moléculas indutoras ou repressoras provenientes do processo de degradação da biomassa lignocelulósica, eles ainda podem atuar como transceptores; quando podem exercer função na transdução de sinal na célula (CAI et al., 2014; ZHANG et al., 2013).

Na última década, diferentes estudos realizados com transportadores de açúcar de $T$. reesei, mostraram que a deleção dessas proteínas pode, de alguma forma, afetar a expressão tanto de genes de celulases quanto de xilanases.

Estudos realizados durante o cultivo de linhagens de T. reesei, em presença de lactose, mostraram que a deleção do transportador (Trire2:3405) resultou em perda da capacidade de absorção de lactose e indução de expressão de genes de celulases (IVANOVA et al., 2013). O mesmo foi relatado em estudos realizados com outros dois transportadores, Trire2: 77517 e 
Introdução

Trire2:79202, no qual a deleção destes também resultou em diminuição da absorção de lactose e expressão de genes de celulases (PORCIUNCULA et al., 2013).

Em contrapartida, estudos realizados com o transportador STP1 mostraram que o transportador estaria envolvido na resposta à repressão catabólica de carbono $(\mathrm{CCR})$ em $T$. reesei. Capaz de transportar tanto glicose quanto celobiose, a deleção do transportador STP1 resultou em um aumento na expressão de genes de celulases e xilanases em presença de celulose microcristalina. Na cepa selvagem, esse transportador poderia carrear glicose proveniente da hidrólise da celulose para o ambiente intracelular da célula fúngica e resultar na repressão dos genes de celulase. Com a deleçãodele, a diminuição no transporte de glicose causou uma menor repressão de genes de celulase (ZHANG et al., 2013).

Diminuindo o transporte de glicose, através da deleção do transportador, foi possível observar o aumento tanto na expressão quanto atividade celulolítica na cepa mutante em relação à parental. Embora o transportador seja capaz de transportar tanto glicose quanto celobiose, a cepa mutante $(\Delta s t p l)$ apresentou uma severa diminuição do crescimento em presença de glicose quando comparado o crescimento em presença de celobiose, indicando que STP1 pode ter maior influência na assimilação de glicose pelo fungo (ZHANG et al., 2013).

Adicionalmente, análises realizadas entre as cepas selvagem e mutante revelaram que a deleção do transportador STP1 resultou em aumento da expressão do fator de transcrição XYR1 que atua como regulador positivo do processo de indução de genes de celulases e hemicelulases (CASTRO et al., 2014). A deleção desse transportador também promoveu o aumento da expressão de outro transportador de açúcar: o Ctr1(ZHANG et al., 2013).

Ctr1, além de estar envolvido com o transporte de lactose, apresenta uma função no processo de sinalização em presença de celulose. A deleção do gene que codifica para esse transportador resultou na completa perda da expressão e secreção de celulases na cepa mutante em presença de celulose e soforose. No entanto, em presença de xilana, tanto o crescimento do fungo quanto a expressão de hemicelulases não apresentaram diferença quando comparadas à cepa parental. Além disso, a deleção do transportador não resultou em diferença no transporte de açúcares, como celobiose e soforose, pelo fungo. Os dados sugeriram que, apesar de não apresentar função no transporte dos açúcares analisados, esse transportador de açúcar, de alguma forma, exerce uma função essencial na sinalização celular em presença de celulose (ZHANG et al., 2013). 
Introdução

Já em presença de xilana, o transportador de açúcar denominado TrSTR1 foi essencial para utilização de pentoses (tanto xilose e arabinose, quanto seus derivados, xilitol e arabinol) por T. reesei. A deleção desse transportador resultou em uma diminuição na expressão de genes de xilanases, além de minimizar a atividade enzimática de xilanases (HEROLD et al., 2013; HUANG et al., 2015).

Em Neurospora crassa, um fungo celulolítico modelo no estudo de degradação da celulose, foi relatado que a presença de pelo menos um dos transportadores de açúcar CDT-1 ou CDT-2 é necessária para o processo de sinalização para indução de celulases em presença de celulose microcristalina. A deleção dos genes $c d t 1$ e $c d t 2$, que codificam para tais transportadores em $N$. crassa, teve como consequência o bloqueio da capacidade de celulose induzir a expressão de genes de celulase na cepa deletada (CAI et al., 2014).

A expressão dos genes $c d t 1$ e $c d t 2$ de $N$. crassa em $S$. cerevisiae mostrou que ambos possuem a capacidade de transportar celodextrina. Em N. crassa, uma cepa resultante da deleção de três genes de $\beta$-glicosidases $(\Delta 3 \beta G)$ e de ambos transportadores (CTD-1 e CTD2), não foi capaz de induzir a expressão de genes de celulases em presença celobiose. Os dados sugerem que esses transportadores podem atuar como transceptores, com uma dupla função: atuar no transporte de celobiose e como um receptor de sinal que posteriormente causaria a ativação da expressão de genes de celulases (CAI et al., 2014; ZNAMEROSKI et al., 2014).

Também em $N$. crassa, foi constatado que uma proteína putativa transportadora de celodextrina, CLP (cellodextrin transporter-like protein), denominada CLP1, é um componente essencial da via de indução de celulases. Apesar dessa proteína não ser capaz de transportar celodextrinas, CLP1 reprime a indução de genes de celulase tanto em presença de celobiose quanto em presença de celulose microcristalina. A co-deleção dos genes $c l p 1$ e $c d t$ 2 na linhagem $\triangle 3 \beta G$ (resultando a linhagem CLP7), revelou um aumento de quase 7 vezes na expressão de genes de celulases. Foi relatado que a repressão da expressão de celulases por CLP1 ocorreu em consequência da repressão da expressão de transportadores de celodextrina, particularmente a expressão de $c d t 1$. A análise do transcriptoma da cepa CPL7, super produtora de celulases, mostrou que toda a maquinaria responsável pela expressão celulolítica; genes de celulases, transportadores de açúcares indutores e os principais fatores de transcrição, foram drasticamente estimulados (CAI et al., 2015).

Como descrito, o transporte de oligossacarídeos solúveis provenientes da hidrólise da holocelulose representa um potencial ponto de controle de toda a cascata de indução de 
Introdução

CAZymes. Dada a importante função dos transportares de açúcar, essas proteínas se tornam essenciais na utilização da biomassa lignocelulósica pelo fungo. Através do transporte de moléculas e da participação em processos de sinalização na célula do fungo, os transportadores, consequentemente, influenciam a expressão de genes CAZymes.

\subsection{Relevância do estudo dos transportadores de açúcar de $T$. reesei para a produção de etanol 2G}

O processo de obtenção de etanol a partir da biomassa lignocelulósica apresenta diferentes gargalos. Para melhor demonstrar a relevância do estudo dos transportadores de açúcar para a produção de etanol 2G, aqui, algumas das limitações encontradas em duas etapas; hidrólise e fermentação, serão expostas.

A rota mais desenvolvida e utilizada na maior parte do mundo para a produção de etanol de segunda geração é a bioquímica (HAMELINCK; VAN HOOIJDONK; FAAIJ, 2005). Para se obter o etanol de segunda geração nessa rota, é necessário - após um prétratamento (que pode ser físico, químico ou biológico) - hidrolisar o bagaço, com a utilização de ácidos ou enzimas, para liberação de açúcares simples que, posteriormente, na etapa de fermentação, serão convertidos em etanol (ZABED et al., 2016).

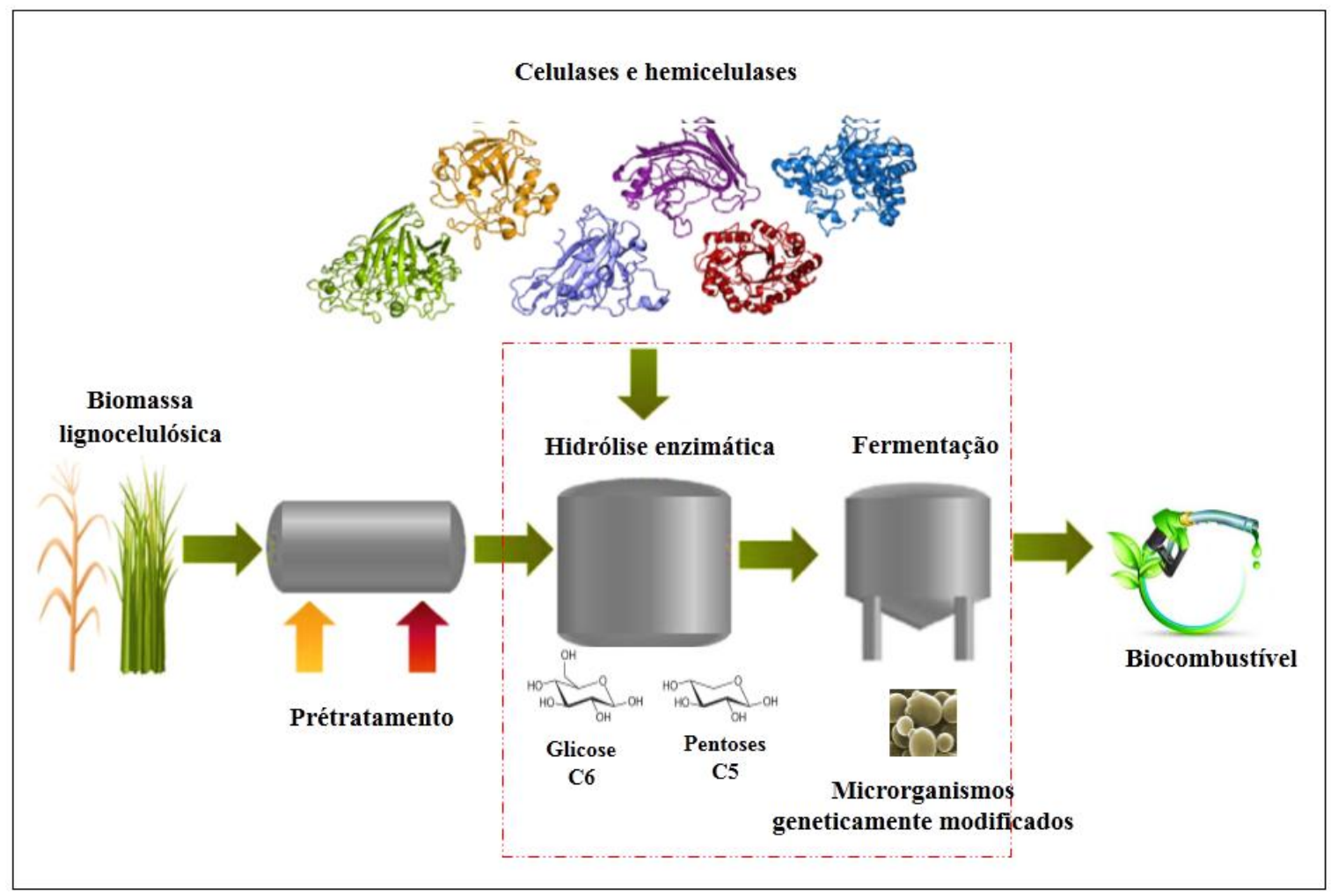

Figura 4. Esquema das etapas de produção de etanol a partir da biomassa lignocelulósica. Em destaque (vermelho) se encontram as duas etapas nas quais o estudo de transportadores de açúcar pode ser aplicado com o objetivo de contribuir para o melhoramento da produção de etanol 2G. Adaptado de PAYNE et al., 2015. 
No processo de hidrólise, as vantagens na utilização de enzimas se sobressaem em relação ao uso de ácidos. No entanto, o alto custo comercial das enzimas utilizadas no processo torna-se uma limitação.

As grandes responsáveis pela hidrólise enzimática da celulose e hemicelulose durante processo de obtenção do bioetanol são as celulases e hemicelulases. O custo elevado dessas enzimas tem aumentado a busca por fontes mais acessíveis, e é neste ponto que entram os microrganismos lignocelulolíticos (MARTINEZ et al., 2008).

O fungo $T$. reesei é um dos principais produtores de enzimas celulolíticas e xilanolíticas (GUPTA et al., 2016). O melhoramento da capacidade do fungo de produzir essas enzimas necessárias para a degradação da biomassa da maneira mais eficiente possível e, posteriormente, atingir essa mesma eficiência em escala industrial poderia causar um impacto no preço das enzimas e, consequentemente, no valor comercial de etanol 2G.

Estudos sobre a influência dos transportadores de açúcar durante o processo de regulação de celulases e hemicelulases abrem portas para, no futuro, se obter cepas modificadas com maior produção enzimática.

Considerando que transportadores de açúcar podem, em condições específicas, interferir na ação de enzimas hidrolíticas que atuam diretamente no polímero de celulose. Fatores que interfiram na produção de celulases e hemicelulases podem contribuir grandemente para o aumento da produção industrial do bioetanol, uma vez que, quando estão ativos, a síntese de tais enzimas é aumentada e a disponibilização dos açúcares para a produção do bioetanol torna-se mais eficiente.

Em contrapartida, fatores que reprimam a produção de celulases e hemicelulases em presença de fontes de carbono prontamente metabolizáveis representam um grande desafio para indústria biotecnológica, já que a capacidade de produção destas enzimas torna-se prejudicada.

Nesse contexto, através da superexpressão e/ou deleção de transportadores de açúcar no hospedeiro endógeno - já caracterizados por apresentarem um papel essencial na indução ou repressão de genes de celulases e/ou xilanases, seria possível burlar a regulação negativa de genes de CAZymes e, ainda, beneficiar processos de sinalização envolvidos na regulação positiva dessas enzimas.

Além disso, o estudo de transportadores de açúcar apresenta uma importante aplicação biotecnológica na etapa de fermentação. A hidrólise das frações celulósica e hemicelulósica 
Introdução

geram, principalmente, os açúcares glicose e xilose, respectivamente (FUJITA et al., 2002). Na etapa de fermentação, a utilização de glicose por meio da levedura Saccharomyces cerevisiae, utilizada industrialmente para produção em larga escala, é um processo bem consolidado. No entanto, o mesmo não ocorre com pentoses, visto que esta levedura não é capaz de metabolizar esse açúcar (MOHD AZHAR et al., 2017).

Para que ocorra o processo de fermentação, os açúcares monoméricos provenientes do hidrolisado são transportados para o ambiente intracelular na levedura, onde serão metabolizados e convertidos em um produto (etanol), que normalmente será transportado ativamente por outros transportadores para o exterior da célula (MUSSATTO; TEIXEIRA, 2010).

Cada transportador tem uma especificidade e taxa de absorção intrínseca frente a um açúcar. Em organismos que naturalmente utilizam açúcares como fonte de energia, os sistemas reguladores endógenos controlam a indução de transportadores de maneira a otimizar esse processo frente a diversas condições in vivo. Por exemplo, a levedura S. cerevisiae, amplamente utilizada industrialmente, possui pelo menos 20 transportadores de açúcar capazes de transportar glicose. Em condições industriais e in vitro, mesmo que a levedura não seja capaz de metabolizar diretamente vários açúcares, alguns desses transportadores também são capazes de transportar xilose, arabinose ou galactose, cada uma com diferentes afinidades e taxa de absorção (APEL et al., 2016; WIECZORKE et al., 1999).

S. cerevisiae não possui os genes que codificam transportadores específicos de xilose e celobiose em seu genoma. Para pentoses, apesar de serem transportadas por alguns transportadores de glicose, este sistema funciona de forma ineficiente, apresentando uma eficiência até 200 vezes menor. Além disso, a absorção de xilose é fortemente suprimida pela glicose devido à competição pelo mesmo transportador (SEDLAK; HO, 2004; UNCOUPLES; SENSING, 2017).

Os transportadores têm uma afinidade diferente para diferentes açúcares e serão seletivos para um substrato específico quando uma mistura de açúcares estiver disponível. Isso se torna um problema para a produção industrial de etanol 2G (DIALLINAS, 2014; ROMANÍ et al., 2015; SLOOTHAAK et al., 2016a). A fermentação da glicose, por meio da levedura Saccharomyces cerevisiae, utilizada industrialmente para produção em larga escala, é um processo bem consolidado. No entanto, o mesmo não ocorre com pentoses, visto que esta levedura não é capaz de produzir etanol a partir de xilose (MOHD AZHAR et al., 2017)

S. cerevisiae é capaz de metabolizar naturalmente apenas frutose e glicose, tendo 
Introdução

transportadores que são otimizados particularmente para o transporte desses açúcares (MOHD AZHAR et al., 2017). Entretanto, fungos filamentosos como o Trichoderma reesei são capazes de metabolizar uma ampla variedade de açúcares a partir de biomassa lignocelulósica, como xilose e celobiose e possuem transportadores otimizados para o transporte desses açúcares (DOS REIS et al., 2016; SLOOTHAAK et al., 2016a).

Foi relatado que, com a reconstituição do sistema de transporte de celodextrina capaz de transportar celobiose de Neurospora crassa para S. cerevisiae durante um processo simultâneo de hidrólise e fermentação, o processo usando estirpes modificadas converteu mais rapidamente celulose em etanol quando comparado com o processo usando levedura selvagem (YAMAMOTO et al., 2010).

A inserção, em S. cerevisiae, de genes que codificam transportadores otimizados para o transporte de diferentes açúcares provenientes na hidrólise da biomassa lignocelulósica, em adição de genes que codificam enzimas responsáveis pela metabolização destes açúcares, torna-se uma importante estratégia na busca por linhagens de leveduras mais eficientes para aplicação na etapa de fermentação.

Durante vários anos, a busca por avanços tecnológicos para superar os gargalos da produção brasileira de bioetanol foi principalmente focada nos aspectos agronômicos e de engenharia associada à produção, enquanto que processos microbiológicos associados à etapa de fermentação não se desenvolveu no mesmo grau (PAULINO et al., 2018). Apenas nas últimas duas décadas, vários estudos começaram a se concentrar no isolamento e engenheiramento de cepas de leveduras que podem melhorar o processo de fermentação, contribuindo para produção de etanol (GALAZKA et al., 2010; ROMANÍ et al., 2015).

A utilização de linhagens de leveduras mais adaptadas ao processo de produção de etanol brasileiro e capazes de fermentar não somente glicose, mas outros açúcares provenientes da biomassa lignocelulósica, como pentoses, torna-se essencial na busca por avanços tecnológicos que contribuam para que o etanol de segunda geração se torne mais barato que o de primeira.

Neste contexto, estudos que envolvem transportadores de açúcar em $T$. reesei compreendem pesquisas preliminares com possível aplicação biotecnológica em dois estágios da produção de etanol 2G; hidrólise e fermentação. Com a identificação e caracterização de transportadores de açúcar em $T$. reesei poderemos adquirir os dados necessários para, futuramente, promover e facilitar a engenharia de cepas com eficiente absorção de açúcares derivados da hidrólise da BML. 


\subsection{Ferramentas para identificação e caracterização de transportadores de açúcar}

Nas últimas décadas, diferentes ferramentas têm sido utilizadas com o objetivo de identificar e caracterizar transportadores de açúcar em fungos filamentosos. Após a identificação desses transportadores, a validação funcional é parte essencial em estudos que visam analisar o papel daquele na célula.

\subsubsection{Transcriptômica e proteômica}

T. reesei, em resposta à diferentes condições - como presença de diferentes fontes de carbono - exibe um perfil de expressão e secreção de uma variedade de proteínas. A análise de dados como esses, que permitem uma visão do conjunto de genes transcritos e proteínas envolvidos em processos celulares frente à uma condição fisiológica/tratamento em específico, representam uma importante ferramenta na identificação de transportadores de açúcar.

A célula, em presença de determinada fonte de carbono, irá expressar genes que codificam para transportadores de açúcar potencialmente envolvidos no transporte e/ou sinalização da fonte de carbono em específico. Através da utilização de técnicas como RNAseq (RNA sequencing), que fornecem o perfil completo da expressão de transcritos (RNAs), transcriptoma, na célula em resposta à condição de estudo, é possível a identificação e quantificação da expressão de genes que codificam para proteínas potencialmente envolvidas no processo (ATANASOVA et al., 2013; BISCHOF et al., 2013; BORIN et al., 2017). No capítulo I dessa tese, o transportador de açúcar caracterizado, Tr69957, foi previamente identificado por nosso grupo de pesquisa através de análises do transcriptoma de T. reesei cultivado em presença de celulose microcristalina e bagaço de cana-de-açúcar.

Além de análises de transcriptoma, uma variedade de transportadores de açúcar têm sido identificados através de metodologias que utilizam proteômica como ferramenta (SLOOTHAAK et al., 2015, 2016b). Como os transportadores são um grupo de proteínas de membrana, podem ser utilizadas metodologias que realizam extração e/ou isolamento de proteínas de membrana para posterior análise. A composição do conjunto de proteínas extraídas a partir do cultivo do fungo na condição de interesse, pode ser analisada usando uma combinação de cromatografia líquida (LC) e espectrometria de massas (MS). Esta abordagem inclui a separação, por cromatografia líquida, dos peptídeos obtidos após digestão tríptica de 
Introdução

extrato proteico, seguida por análise por espectrometria de massas (CHURCHWELL et al., 2005). No capítulo III dessa tese, diversos transportadores de açúcar foram identificados utilizando tal ferramenta.

A utilização dessas ferramentas permite a identificação de proteínas ou transcritos expressos, analisar níveis de expressão, respostas das células à diferentes condições e ainda diferenças nos perfis de expressão entre diferentes linhagens.

Os dados provenientes de ambas análises, tanto transcriptoma quanto proteoma, requerem posterior processamento utilizando ferramentas de bioinformática para identificar transcritos ou proteínas de interesse.

\subsubsection{Ferramentas de bioinformática}

Análises de proteômica e transcriptômica geram uma ampla quantidade de informação, sendo necessária a utilização de ferramentas que permitam a interpretação e integração desses dados. Atualmente uma variedade de microrganismos possuem disponível bancos de dados contendo informações provenientes do sequenciamento completo do genoma. Através desse banco de dados e utilizando ferramentas de bioinformática, é possível identificar e quantificar uma ampla variedade de genes e proteínas.

Em estudo de proteômica, diferentes softwares, como Maxquant e Proteome Discoverer, realizam a identificação de peptídeos e proteínas baseando-se em proteínas presentes em bancos de dados para a interpretação e integração de dados (ENG; MCCORMACK; YATES, 1994; TYANOVA; TEMU; COX, 2016). Além disso, através da utilização de softwares, como Perseus, é possível realizar tanto análises qualitativas quanto quantitativas dos dados obtidos (TYANOVA et al., 2016).

Proteínas com função de transporte possuem domínios hidrofóbicos que os permitem permear a membrana celular. Utilizando softwares, como TMHMM server e TMRPres $2 D$, é possível realizar a busca por domínios transmembrana através da análise da sequência de aminoácidos das proteínas identificadas (Figura 5). Utilizando um algoritmo baseado em um Modelo oculto de Markov, o software TMHMM consegue predizer a localização de uma possível região transmembrana (SONNHAMMER; VON HEIJNE; KROGH, 1998).

A utilização desses softwares, para predição de estruturas proteicas secundárias em conjunto a análises de alinhamento de sequências de proteínas, representa importante ferramenta na análise de dados provenientes de experimentos que abrangem transcriptômica e proteômica. 
A

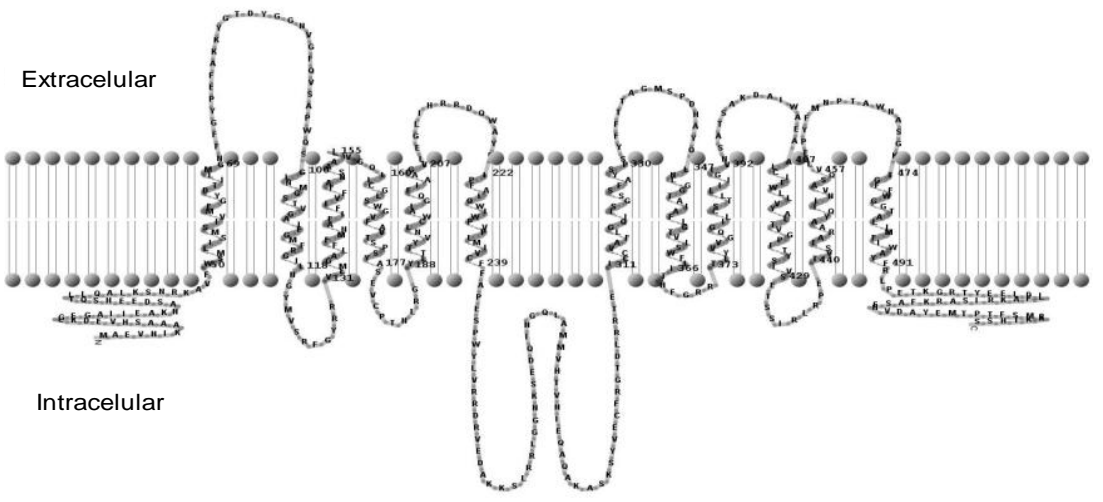

B

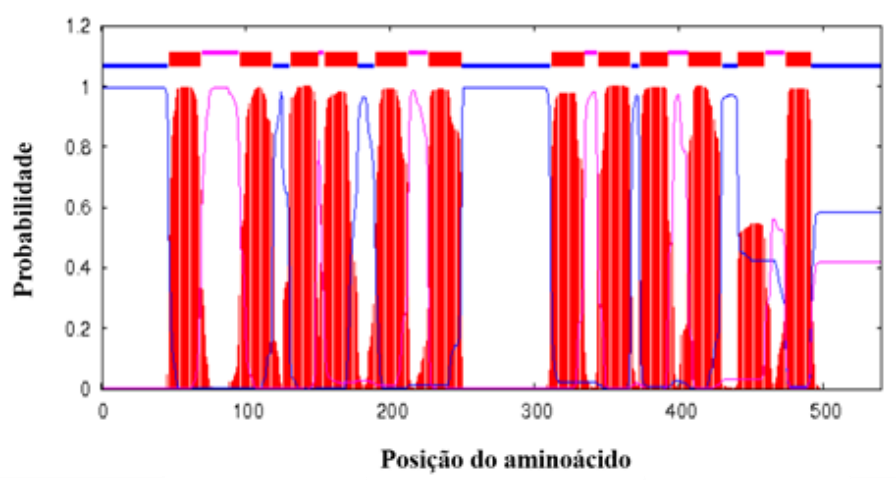

Figura 5. (A) Representação esquemática da possível topologia predita de um transportador de açúcar de $T$. reesei de acordo com o programa TMRPres2D. (B) Predição de hélices transmembranares do transportador (predito via: http://www.cbs.dtu.dk/services/TMHMM/).

\subsubsection{Ancoragem molecular (ou docking molecular)}

Ancoragem molecular é uma ferramenta que pode ser usada para predizer a melhor interação de ajuste entre uma pequena molécula (ligante) e uma proteína à nível atômico. Com isso, a utilização dessa ferramenta permite tanto caracterizar o comportamento de pequenas moléculas no sítio de ligação de proteínas alvo, quanto elucidar interações moleculares. O processo de ancoragem molecular envolve duas etapas básicas: predição da conformação do ligante, bem como sua posição e orientação dentro do sítio de ligação e avaliação da afinidade de ligação (YANG, 2004).

Utilizando essa ferramenta é possível obter informações sobre a afinidade do transportador de interesse frente à diferentes açúcares. Prever quão bem o açúcar pode ligar-se ao transportador, onde ele pode ligar-se, e que tipos de interações poderia formar no local de ligação. Variados softwares, como iGEMDOCK, podem ser empregados para realização desse estudo (YANG; CHEN, 2004). 


\subsubsection{Validação funcional}

Para o estudo de transportadores, a validação funcional deve prosseguir análises de identificação dessas proteínas. Diferentes métodos podem ser utilizados para validação funcional de candidatos ao transporte de açúcares, entre eles podemos citar: a deleção genética do transportador no seu hospedeiro, que apresenta um sistema de transporte funcional, e ainda, a expressão do transportador de interesse em uma célula hospedeira que, naturalmente ou através de engenharia genética, não apresente um sistema de transporte funcional (COLABARDINI et al., 2014; DOS REIS et al., 2016; HUANG et al., 2015; SLOOTHAAK et al., 2016a).

O transportador de interesse pode ser deletado da célula endógena e a perda de função pode ser determinada através da quantificação do fenótipo resultante. Fenótipos como diminuição de crescimento do fungo em determinadas fontes de carbono e diminuição da taxa de absorção de determinados açúcares podem fornecer importantes informações sobre o tipo de açúcar transportado. Além disso, a deleção do transportador pode promover estudos da influência deste em processos celulares. Comparações, utilizando análises de expressão genética diferencial, entre a cepa parental e deletada, podem fornecer um melhor conhecimento à respeito da função e como a deleção do transportador pode influenciar a expressão de outros genes envolvidos em diversas vias celulares (FEKETE et al., 2012; PORCIUNCULA et al., 2013; SLOOTHAAK et al., 2016a).

O método de deleção (Figura 6) desenvolvido por pesquisadores da Universidade Tecnológica de Viena, Áustria, tem sido amplamente utilizado como ferramenta para estudos em T. reesei (SCHUSTER et al., 2012). Nesse método, um vetor de deleção é construído por recombinação homóloga em levedura. Para isto, o gene que codifica para o gene orotidine-5'-phospahte descarboxylase (pyr4) de T. reesei (Tr74020) é utilizado como marcador de seleção. Iniciadores para amplificação da região promotora ( $5 \mathrm{~F}$ e $5 \mathrm{R})$ e terminadora (3F e $3 \mathrm{R})$ do gene de interesse são construídos contendo sequências de homologia - que são adicionadas aos oligonucleotídeos iniciadores - com o marcador de seleção pyr4 e com o vetor de transformação em levedura pRS426, de forma a permitir a recombinação homóloga mediada por levedura. Após amplificação, as sequências e o vetor são inseridos na levedura são inseridas na levedura através de técnicas de transformação genética.

Em seguida, o DNA total da levedura é extraído e o cassete de deleção é amplificado através da técnica de PCR (Reação em Cadeia de Polimerase), utilizando 
Introdução

iniciadores específicos. O produto final dessa amplificação é inserido, utilizando técnicas de transformação celular, em uma linhagem de T. reesei que possui auxotrofia para uridina. Com a posterior seleção de cepas que apresentam a deleção do gene de interesse, análises funcionais podem ser realizadas.

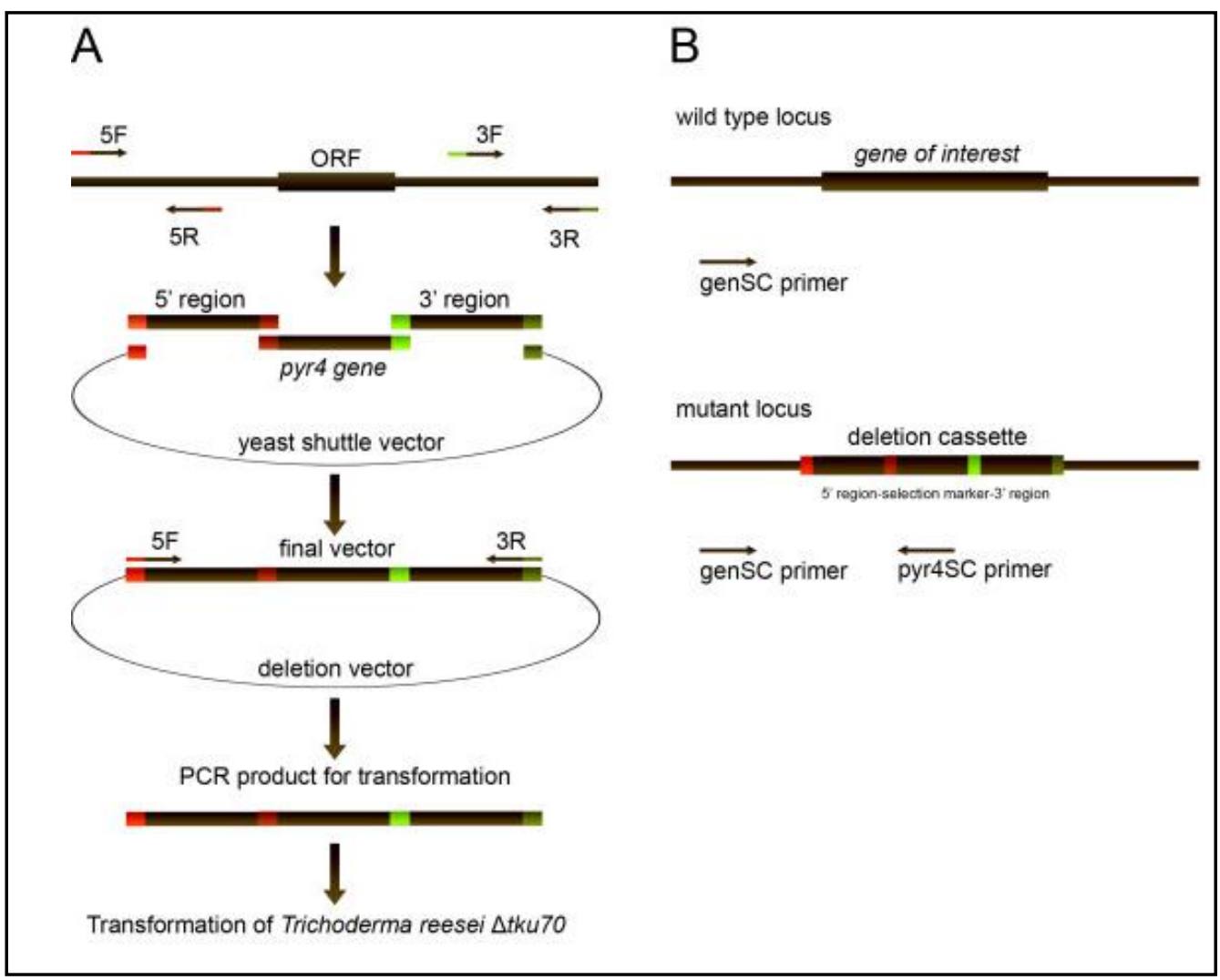

Figura 6. Estratégia de deleção genética em Trichoderma reesei(SCHUSTER et al., 2012).

Análises ex vivo também representam uma importante ferramenta para a validação funcional de transportadores de açúcar. Para isso, uma linhagem de levedura engenheirada $S$. cerevisiae (S. cerevisiae EBY.VW4000), vem sendo amplamente utilizada.

S. cerevisiae EBY.VW4000 possui mais de vinte transportadores de açúcares e sensores deletados, sendo capaz de utilizar somente maltose como fonte de carbono (WIECZORKE et al., 1999). Por não apresentar um sistema de transporte funcional, a inserção do transportador de estudo e o crescimento da levedura na fonte de carbono candidata ao transporte, já pode indicar a funcionalidade do transportador. Utilizando esse sistema, diferentes parâmetros de transporte podem ser analisados, incluindo a especificidade do transportador para diferentes açúcares (POLIDORI et al., 2007; REIS et al., 2013; SLOOTHAAK et al., 2016b).

Além disso, a localização intracelular dos transportadores em S. cerevisiae pode ser 
Introdução

conferida por meio da construção de cassetes contendo o gene específico fusionado à GFP (Proteína verde fluorescente). Nessa estratégia, a ORF (fase de leitura aberta, do inglês open reading frame) do transportador de $T$. reesei selecionado poderá ser amplificada a partir do cDNA, utilizando iniciadores específicos para cada gene. Iniciadores utilizados para amplificar a ORF do transportador devem conter sequências de homologia com o vetor e ao gene que codifica para GFP. Enquanto que os utilizados para amplificação do gene que codifica para GFP, deverão apresentar sequências de homologia com o vetor e a ORF. Estas sequências de homologia são cruciais para promover o processo de recombinação homóloga. Um vetor aberto, contendo uma marca de seleção, e as sequências correspondentes à ORF do transportador e a GFP são inseridas na levedura através de técnicas de transformação genética.

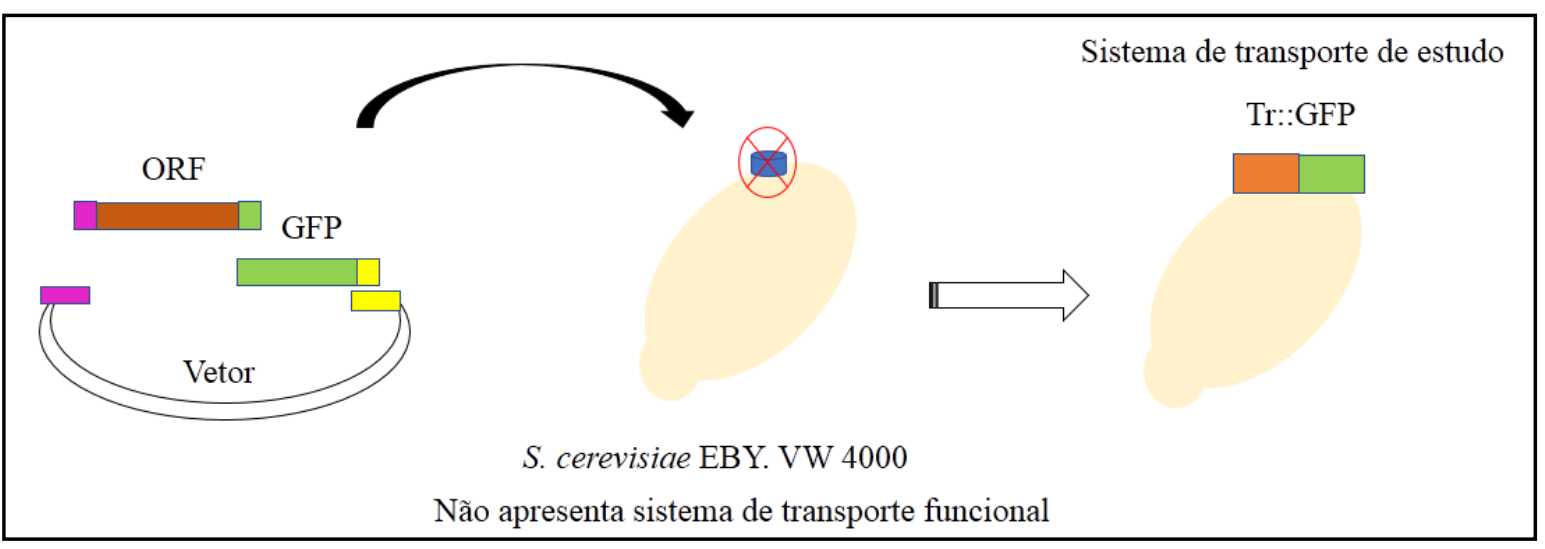

Figura 7. Estratégia de recombinação homóloga em uma linhagem de levedura que não apresenta um sistema de transporte funcional para caracterização de transportadores de açúcar.

Geralmente, análises ex vivo do transportador são suficientes para estudos de funcionalidade (SLOOTHAAK et al., 2015, 2016b), no entanto, estratégias de deleção do transportador na célula endógena pode fornecer uma visão mais ampla da função que eles desempenham na célula. A combinação das duas estratégias é essencial para melhor compreensão de mecanismos moleculares nos quais esses transportadores podem estar envolvidos.

\section{Família de transportadores com função no transporte de açúcares: MFS (major facilitator superfamily) permease}

MFS (Major Facilitator Superfamily) permease é o maior e mais diverso grupo de transportadores presente em todos os tipos de células (QUISTGAARD et al., 2016). Os 
Introdução

membros dessa superfamília são capazes de transportar por meio da membrana uma diversidade de substratos, incluindo: açúcares simples, oligossacarídeos, nucleosídeos, drogas, aminoácidos, cátions e ânions orgânicos e inorgânicos. (KASHO; SMIRNOVA; KABACK, 2006).

MFS têm sido definida como uma família de transportadores que apresentam, em geral, uma característica estrutural semelhante; duas unidades estruturais formadas por 6 segmentos transmembrana em $\alpha$-hélice, conectados por uma cavidade hidrofílica central, apresentando regiões amino e carboxila-terminal longas voltados para o citoplasma da célula. Essa estrutura é resultado de proteínas compostas por 500 a 600 aminoácidos que codificam um total de 12 segmentos transmembrana. MFS apresentam duas sequências conservadas; um entre as hélices 2 e 3, e outro entre as hélices 8 e 9 (LAW; MALONEY; WANG, 2008; PAO; PAULSEN; SAIER, 1998; QUISTGAARD et al., 2016).

Em se tratando de transportadores de açúcar, em fungos filamentosos, a família de proteínas MFS permeases, é considerada o mais relevante grupo de proteínas destinadas a este fim. Grande parte dos transportadores de açúcar em fungos, realizam o transporte do substrato através da membrana por difusão facilitada ou transporte ativo (COLABARDINI et al., 2014; DOS REIS et al., 2016; SLOOTHAAK et al., 2016a).

O genoma de fungos filamentosos codificam um grande número de transportadores de MFS, sendo predito que os genomas de T. reesei e A. nidulans codifiquem 164 e 357 proteínas, respectivamente, pertencentes à MFS (DOS REIS et al., 2016; RIES et al., 2013a). No entanto, não se sabe exatamente quantas delas estão envolvidas no transporte de açúcar.

Em fungos filamentos, MFS permeases, com função no transporte de açúcar, possuem a característica de um mesmo transportador ser capaz de translocar diferentes açúcares através da membrana (NOGUEIRA et al., 2018; ZHANG et al., 2015). Por exemplo, o transportador XtrD de A. nidulans mostrou ser capaz de transportar diferentes monossacarídeos, como xilose e glicose, já em T. reesei, o transportador STP1 mostrou estar envolvido no transporte de glicose e celobiose (COLABARDINI et al., 2014; ZHANG et al., 2013). No entanto, somente um pequeno número de transportadores de açúcar foram funcionalmente caracterizados em fungos filamentosos. 


\section{Objetivos}

O objetivo geral desse trabalho foi contribuir para o entendimento dos mecanismos moleculares envolvidos no processo de desconstrução da biomassa em $T$. reesei através da caracterização de transportadores de açúcar associados a esse processo.

Dentre os objetivos específicos, pode-se citar:

- Deletar o gene do transportador identificado e selecionado pela análise in silico;

- Analisar o fenótipo da linhagem mutante - 1) Cultivar a linhagem T. reesei parental e mutante em diversas fontes de carbono, a fim de se verificar o perfil de expressão gênica por PCR em tempo real; 2) realizar análise do crescimento do fungo em presença de diversas fontes de carbono; 3) analisar absorção de açúcares por cromatografia líquida de alta eficiência (HPLC, do inglês High performance liquid chromatography);

- Demonstrar a funcionalidade do gene codificador para o transportador de açúcar de $T$. ressei selecionado, avaliando a complementação funcional de cada transportador na linhagem de S. cerevisiae EBY.VW4000.

- Identificar novos transportadores de açúcar potencialmente envolvidos no processo de degradação de celulose, através de análise proteômica. 
MATERIAL E MÉTODOS/RESULTADOS 


\section{Material e métodos/Resultados}

\subsection{Capítulo I}

Diz respeito a artigo publicado com as especificações que se seguem.

Título: Characterization of a novel sugar transporter involved in sugarcane bagasse degradation in Trichoderma reesei

Autores: Karoline M. V. Nogueira, Renato Graciano de Paula, Amanda Cristina Campos Antoniêto, Thaila F. dos Reis, Cláudia Batista Carraro, Alinne Costa Silva, Fausto Almeida, Carem Gledes Vargas Rechia, Gustavo H. Goldman and Roberto N. Silva.

Periódico: Biotechnology for Biofuels (2018) 11:84.

DOI: https://doi.org/10.1186/s13068-018-1084-1 
Capítulo I

\title{
Characterization of a novel sugar transporter involved in sugarcane bagasse degradation in Trichoderma reesei
}

Karoline M. V. Nogueira', Renato Graciano de Paula ${ }^{1}$, Amanda Cristina Campos Antoniêto' ${ }^{1}$, Thaila F. dos Reis², Cláudia Batista Carraro', Alinne Costa Silva', Fausto Almeida', Carem Gledes Vargas Rechia²,

Gustavo H. Goldman ${ }^{2}$ and Roberto N. Silva ${ }^{1 *}$ ()

\begin{abstract}
Background: Trichoderma reesei is a saprophytic fungus implicated in the degradation of polysaccharides present in the cell wall of plants. T. reesei has been recognized as the most important industrial fungus that secretes and produces cellulase enzymes that are employed in the production of second generation bioethanol. A few of the molecular mechanisms involved in the process of biomass deconstruction by T. reesei; in particular, the effect of sugar transporters and induction of xylanases and cellulases expression are yet to be known.

Results: In our study, we characterized a novel sugar transporter, which was previously identified by our group through in silico analysis of RNA-seq data. The novel T. reesei 69957-sugar transport system (Tr69957) is capable of transporting xylose, mannose, and cellobiose using a T. reesei 69957-sugar transport system in Saccharomyces cerevisiae. The deletion of Tr69957 in T. reesei affected the fungal growth and biomass accumulation, and the sugar uptake in the presence of mannose, cellobiose, and xylose. Molecular docking studies revealed that Tr69957 shows reduced protein-ligand binding energy for interactions towards disaccharides in comparison with monosaccharides. Furthermore the deletion of Tr69957 affected the gene expression of cellobiohydrolases (cel7a and cel6a), $\beta$-glucosidases (cel3a and cel1a), and xylanases (xyn1 and xyn2) in the cultures of parental and mutant strains in the presence of cellobiose and sugarcane bagasse (SCB).

Conclusion: The transporter Tr69957 of T. reesei can transport cellobiose, xylose, and mannose, and can affect the expression of a few genes encoding enzymes, such as cellulases and xylanases, in the presence of SCB. We showed for the first time that a filamentous fungus ( $T$. reesei) contains a potential mannose transporter that may be involved in the degradation of cellulose.
\end{abstract}

Keywords: Trichoderma reesei, Sugarcane bagasse, Cellulase, Sugar transporter, Docking, Saccharomyces cerevisiae, Biofuel

\section{Introduction}

The fungus Trichoderma reesei is one of the most studied microorganisms and is known for its ability to degrade lignocellulose [1]. T. reesei has an efficient degradation system for major polysaccharides

\footnotetext{
"Correspondence: rsilva@fmrp.usp.br

Department of Biochemistry and Immunology, Ribeirăo Preto Medica School, University of São Paulo, Ribeirão Preto, SP, Brazil
}

Full list of author information is available at the end of the article present in the plant cell wall, and thus, it is commercially exploited for its effective production and secretion of a wide range of cellulases, hemicellulases, and other Carbohydrate-Active Enzymes (CAZymes) $[1,2]$. The expression of CAZymes-encoding genes occurs in a carbon-source-dependent manner and may be regulated by several transcription factors and small molecules that mediate the control of gene expression [3] Moreover, a wide diversity of mono- and disaccharides is naturally found during biomass hydrolysis, being
BioMed Central

(- The Author(s) 2018. This article is distributed under the terms of the Creative Commons Attribution 4.0 International License (http//creativecommons.org/licenses/by/4.0/), which permits unrestricted use, distribution, and reproduction in any medium, provided you give appropriate credit to the original author(s) and the source, provide a link to the Creative Commons license, and indicate if changes were made. The Creative Commons Public Domain Dedication waiver (http://creativecommons.org/ publicdomain/zero/1.0/) applies to the data made available in this article, unless otherwise stated. 
able to act as regulatory molecules $[1,4]$. Accordingly, a complex carbon source such as sugarcane bagasse (SCB), which is the major residue form the Brazilian agroindustry and constituted by cellulose (40-50\%), hemicellulose $(25-35 \%)$, and lignin $(15-20 \%)$, can be efficiently degraded by fungal enzymes to release key regulatory molecules that might in turn activate the expression of genes to improve the sensing of different carbon sources and secretion of cellulolytic enzymes [5, 6].

The access to sugars released from the complex polysaccharides is dependent on the ability of this fungus to secrete high amounts of a complex mix of hydrolytic enzymes, and also the presence of a large array of sugar transporters that are capable of effectively transporting the constituent sugars into the cell [7]. Therefore, the transporters are essential in the utilization of lignocellulose by the fungus, promoting the transport of molecules that signal environmental changes to the cell and, consequently, controlling the CAZymes-encoding gene expression [1]. One of the most relevant sugar transporters families in filamentous fungi is the Major Facilitator Superfamily (MFS) [8]. In the T. reesei genome, approximately 164 predicted MFS transporters have been annotated [9]. However, the involvement of these transporters in sugar uptake is still unclear, and only a few sugar transporters have been functionally characterized in filamentous fungi. Interestingly, the available data show that MFS transporters can recognize and transport more than one type of sugar such as xylose and cellobiose into the cell [10]. For instance, T. reesei STP1 is involved in glucose and cellobiose uptake [8]. Moreover, the $A$. nidulans transporter XtrD was shown to be able to transport several other monosaccharides, in addition to xylose and glucose [11]. After the uptake, these sugars have been shown to play an important role in metabolic signaling in the presence of cellulose [12]. Despite the progress made in studies related to cellulases production, the influence of these transporters on cellulose degradation from various carbon sources remains unknown.

Our group has demonstrated new components involved in cellulose degradation including some transporters. A few of them that were identified in the transcriptome analysis were specifically induced by cellulose, sophorose, and glucose, whereas the MFS family was overrepresented in our analysis in the presence of different carbon sources [3]. Therefore, the aim of this study was to characterize one of the $T$. reese $i$ transporters that was initially identified by RNA-seq and in silico analysis, and to understand its involvement in SCB degradation. We have characterized a $T$. reesei transporter with potential role in the transport of monosaccharides and disaccharides. The characterization of MFS Tr69957 showed that this transporter can better enhance the efficiency of cellobiose, xylose, and mannose transport as compared to that by $T$. reesei mutant strain. In addition, with respect to the cellulases production, it was observed that the deletion of MFS Tr69957 leads to decreased expression of cellulase and xylanase genes as compared to that in the parental strain when both the strains were grown on SCB. Furthermore, for the first time, our results showed that $T$. reesei possesses a potential mannose transporter, which may be involved in the degradation of cellulose.

\section{Materials and methods}

\section{Fungal strains, media, and culture methods}

The fungal strains used in this study are listed in Additional file 1 . The $S$. cerevisiae strain EBY.VW4000 [13] is a hexose-null mutant and it was used for the initial functional analysis of the Tr69957 transporter. The EBY. VW4000 and its mutants (EBY.VW4000 + pRH195m +pRH274 and Tr69957::GFP EBY.VW4000) were grown at $30{ }^{\circ} \mathrm{C}$ in broth or on solid yeast nitrogen base (YNB) medium (which contained $20 \mathrm{~g} / \mathrm{L}$ agar, $7 \mathrm{~g} / \mathrm{L}$ YNB without amino acids and supplemented with $0.05 \mathrm{~g} / \mathrm{L}$ histidine, $0.1 \mathrm{~g} / \mathrm{L}$ leucine, $0.1 \mathrm{~g} / \mathrm{L}$ tryptophan, and $0.1 \mathrm{~g} / \mathrm{L}$ uracil). Selection of transformants was done on the YNB medium lacking tryptophan and uracil. All the reagents were obtained from Sigma Aldrich (St. Louis, MO, USA). The yeast S. cerevisiae SC9721 strain (MATd his3- $\$ 200$

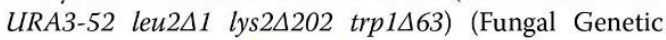
Stock Center-www.fgsc.net) was used to generate the deletion cassette by homologous recombination. This strain was grown at $30{ }^{\circ} \mathrm{C}$ in broth or on solid YNB medium (which contains $20 \mathrm{~g} / \mathrm{L}$ agar, $7 \mathrm{~g} / \mathrm{L}$ YNB without amino acids and supplemented with $0.05 \mathrm{~g} / \mathrm{L}$ histidine, $0.1 \mathrm{~g} / \mathrm{L}$ lysine, $0.1 \mathrm{~g} / \mathrm{L}$ leucine, $0.1 \mathrm{~g} / \mathrm{L}$ tryptophan, $0.1 \mathrm{~g} / \mathrm{L}$ uridine, and $0.1 \mathrm{~g} / \mathrm{L}$ uracil), along with $2 \%(\mathrm{w} / \mathrm{v})$ glucose. The strain QM6a $\Delta$ tmus $53 \Delta P y r 4$ [14] was used as a parental strain to construct the $\Delta 69957$ T. reesei mutant strain. This strain was obtained from the Institute of Chemical Engineering \& Technical Biosciences of Vienna University of Technology, TU Vienna, Austria. The strain was maintained at $4{ }^{\circ} \mathrm{C}$ on MEX medium [ $3 \%(\mathrm{w} / \mathrm{v})$ malt extract and $2 \%(\mathrm{w} / \mathrm{v})$ agar-agar], which was supplemented with $5 \mathrm{mM}$ uridine in the case of the pyr4 deletion strain. To perform gene expression assays, $10^{6}$ cells/ $\mathrm{mL}$ of each specific strain was inoculated into $25 \mathrm{~mL}$ of Mandels-Andreotti medium [15] (MAM) or Minimal Medium (MM) which contains $1 \%(w / v)$ of the selected sugar as the sole carbon source.

\section{Conditions for maintenance of cultures}

Trichoderma reesei strains QM6a $\Delta$ tmus $53 \Delta$ Pyr4 [14] and $\triangle 69957$ were grown in MEX medium at $28{ }^{\circ} \mathrm{C}$ for a period of 7 days. In all the experiments with SCB, the 
parental and $\Delta 69957$ mutant strains were initially grown in $1 \%(\mathrm{w} / \mathrm{v})$ glycerol for 24 and $48 \mathrm{~h}$, respectively, and then transferred to a medium containing SCB. For this purpose, $10^{6}$ cells $/ \mathrm{mL}$ of each specific strain was inoculated into $25 \mathrm{~mL}$ of MAM [15] containing $1 \%$ glycerol, and after $24 \mathrm{~h}$ (parental strain), the mycelium was transferred into $25 \mathrm{~mL}$ of MAM containing $1 \%$ of exploded sugarcane bagasse (ESB). Concerning the $\Delta 69957$ mutant strain, the mycelium was initially grown in $1 \%(\mathrm{w} / \mathrm{v})$ glycerol for $48 \mathrm{~h}$ to achieve an initial mycelial biomass similar to the parental strain, and then, the mycelium was transferred into $25 \mathrm{~mL}$ of MAM containing $1 \%$ ESB. The ESB was prepared as described previously in the corresponding Ref. [16]. Briefly, SCB in natura was treated with $14 \mathrm{~kg} / \mathrm{cm}^{2}$ water steam, thoroughly washed with distilled water until the reducing sugars were not detected by dinitrosalicylic acid (DNS) [17], and dried at $40{ }^{\circ} \mathrm{C}$ for several days. SCB was kindly donated by Nardini Agroindustrial Ltd, Vista Alegre do Alto, São Paulo, Brazil.

The fungal cultures were incubated at $28{ }^{\circ} \mathrm{C}$ for 6,24 , and $48 \mathrm{~h}$ in an orbital shaker (200 rpm) for all the SCB experiments. All experiments were performed in three biological replicates. The resultant mycelia were collected by filtration, frozen in liquid nitrogen, and stored at $-80^{\circ} \mathrm{C}$ for RNA extraction.

\section{Construction of the $\Delta 69957$ mutant strain}

The deletion of Tr69957 gene in T. reesei was performed as described previously by Schuster et al. [18]. To construct the deletion cassette, the orotidine- $5^{\prime}$-phosphate decarboxylase gene of Aspergillus niger ( $p y r G$ ) was used as a selection marker. The flanking sequences of $\operatorname{Tr} 69957$ were obtained from the T. reesei genome database (http://genome.jgi.doe.gov/Trire2/Trire2.home.html). The marker gene and its respective $5^{\prime}$ and $3^{\prime}$ flanking sequences were amplified using the primers as described in Additional file 2. The primers were designed and analyzed with the help of OligoAnalyzer tool (https:// eu.idtdna.com/calc/analyzer). To enable yeast-mediated recombination of the deletion cassette, we used the external 5'-UTR forward and $3^{\prime}$-UTR reverse primers containing cohesive ends with the vector pRS426 $[19,20]$ and the internal $5^{\prime}$-UTR reverse and $3^{\prime}$-UTR forward primers containing cohesive ends with the $5^{\prime}$ and $3^{\prime}$ sequence of the pyrG gene (Additional file 2). The $50-\mu \mathrm{L}$ reaction mixture contained $1 \mathrm{U}$ Platinum Taq DNA Polymerase High Fidelity (Thermo Scientific), $1 \times$ High Fidelity PCR Buffer, $0.2 \mathrm{mM}$ dNTPs, $0.3 \mu \mathrm{M}$ forward and reverse primers, $1 \mu \mathrm{L}$ T. reesei $\mathrm{QM} 9414$ and $A$. niger genomic DNA $(150 \mathrm{ng} / \mu \mathrm{L})$ as a template, and nuclease-free water. The PCR fragments were purified using a QIAquick PCR Purification Kit (Qiagen).
To perform yeast-mediated recombination, we used the yeast shuttle vector pRS426 ( $a m p^{\mathrm{R}}$ lacZ URA3) [19, 20], which was digested with EcoRI and XhoI (Thermo Scientific), and purified with the QIAquick PCR Purification Kit (Qiagen). Yeast transformation was performed as described previously in the corresponding Ref. [21-23]. We prepared an overnight culture $\left(200 \mathrm{rpm}, 30{ }^{\circ} \mathrm{C}\right)$ of the yeast S. cerevisiae SC9721 strain (MATa his3- 4200 URA3-52 leu2 $\Delta 1$ lys $2 \Delta 202$ trp1 $\Delta 63$ ) obtained from Fungal Genetic Stock Center. Then, $1 \mathrm{~mL}$ of this overnight culture was added to $50 \mathrm{~mL}$ of fresh YPD medium (1\% yeast extract, $2 \%$ peptone, $1 \%$ glucose: all of them were obtained from Sigma Aldrich) and incubated at $30{ }^{\circ} \mathrm{C}$ until the attainment of $\mathrm{OD}_{600}=1$. Thereafter, the cells were centrifuged and re-suspended in $100 \mathrm{mM}$ lithium acetate for transformation. To this purpose, equimolar quantities of $5^{\prime}$ and $3^{\prime}$ flanking regions of pyrG gene and the digested pRS426 product were mixed and used for yeast transformation by the lithium acetate method [24]. S. cerevisiae SC9721 transformants were selected for their ability to grow on YPD medium supplemented with lysine, histidine, leucine, and tryptophan, without uracil. S. cerevisiae genomic DNA was extracted using a previously described protocol $[25,26]$. The deletion cassette of Tr69957 was PCR amplified using TaKaRa Ex Taq DNA Polymerase (Clontech) using Tr69957_pRS426_5 forward and Tr69957_pRS426_3 reverse primer (Additional file 2).

\section{Southern blotting}

The selected transformants were analyzed by Southern hybridization using a previously described method [27], to demonstrate that the transformation cassettes had homologously integrated at the targeted T. reesei

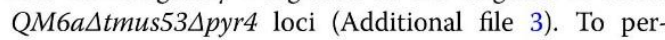
form this analysis, $25 \mu \mathrm{g}$ of total genomic DNA from the parental and mutant strains were digested with EcoRV (Fermentas) overnight, and then, this digested DNA was transferred onto GE Healthcare Amersham Hybond$\mathrm{N}+$ membranes (GE). The probe was generated from the PCR-amplified fragment using Tr69957_pRS426_5fw and Tr69957_pyrG_5rv (Additional file 2) and labeled using a digoxigenin (DIG) DNA labeling kit (Roche, Mannheim, Germany) by following the manufacturer's instructions. Labeling, hybridization, and immunological detection were performed using a non-radioactive labeling and immunological detection kit with CDP-Star as the chemiluminescent substrate (Roche, Mannheim, Germany), by following the methods that were previously described [28]. 


\section{Measurement of dry weight}

A total of $10^{6}$ cells $/ \mathrm{mL}$ of $T$. reesei parental or $\Delta 69957$ mutant strains were inoculated into $25 \mathrm{~mL}$ of MAM supplemented with $1 \%(\mathrm{w} / \mathrm{v})$ glycerol. After $24 \mathrm{~h}$, the parental strain mycelium was transferred into $25 \mathrm{~mL}$ of MAM containing $1 \%(\mathrm{w} / \mathrm{v})$ xylose, cellobiose, or mannose. The mutant strain was grown for $48 \mathrm{~h}$ in MAM containing $1 \%$ $(w / v)$ glycerol to achieve an initial mycelial biomass similar to the parental strain. After 6, 24, and $48 \mathrm{~h}$, mycelia were harvested by filtration, dried by incubation at $70{ }^{\circ} \mathrm{C}$ for $3 \mathrm{~h}$ and subsequently weighed. The experiments were conducted in triplicates for each sample.

Determination of the extracellular sugar concentrations

The uptake of sugars was measured by HPLC analyses. A total of $10^{6}$ cells $/ \mathrm{mL}$ T. reesei parental and $\Delta 69957$ mutant strains were inoculated into $25 \mathrm{~mL}$ of MAM supplemented with $1 \%(\mathrm{w} / \mathrm{v})$ glycerol. After $24 \mathrm{~h}$, the parental strain mycelium was transferred into $25 \mathrm{~mL}$ of MAM containing $1 \%(\mathrm{w} / \mathrm{v})$ or $30 \mathrm{mM}$ of xylose, cellobiose, or mannose in the same culture, at $30{ }^{\circ} \mathrm{C} 200 \mathrm{rpm}$ for 6,24 , and $48 \mathrm{~h}$. The mutant strain was grown for $48 \mathrm{~h}$ in MAM containing $1 \%(\mathrm{w} / \mathrm{v})$ glycerol to achieve an initial mycelial mass similar to that of the parental strain. S. cerevisiae Tr69957::GFP EBY.VW400 strain and EBY.VW4000 + p RH195m + pRH274+pGH1 (control) were inoculated in $100 \mathrm{~mL}$ of YNB medium supplemented with $2 \%(\mathrm{w} / \mathrm{v})$ maltose until they reached the exponential growth phase. Yeast cells were pelleted by centrifugation at $4000 \mathrm{rpm}$ for $5 \mathrm{~min}$, washed three times with $50-\mathrm{mL}$ water, and re-suspended in water. Next, this cell suspension was inoculated (initial $\mathrm{OD}_{600}=0.5$ ) in 50-mL YNB-Trp-UraLeu medium without carbon source and then incubated at $30^{\circ} \mathrm{C}$ for $3 \mathrm{~h}$. Finally, this medium was supplemented with $1 \%(\mathrm{w} / \mathrm{v})$ xylose, cellobiose, or mannose at $30{ }^{\circ} \mathrm{C}$, $150 \mathrm{rpm}$ for $144 \mathrm{~h}$. At each timepoint, $2 \mathrm{~mL}$ of the culture were collected, centrifuged, and the supernatants were stored at $-80^{\circ} \mathrm{C}$. The amount of sugar in the supernatant at each timepoint was determined by ion chromatography (HPLC-Thermo Fisher-U3000), coupled with refractive index detector) Suplecogel C611 column (eluted with $5 \mathrm{mM} \mathrm{H}_{2} \mathrm{SO}_{4}$, at flow rate $0.5 \mathrm{~mL} / \mathrm{min}$ and column temperature $60{ }^{\circ} \mathrm{C}$ ) and Aminex HPX-87P column (eluted with $\mathrm{H}_{2} \mathrm{O}$, at flow rate $0.5 \mathrm{~mL} / \mathrm{min}$ and column temperature $\left.85^{\circ} \mathrm{C}\right)$.

\section{Analysis of the effect of Tr69957 deletion on T. reese} growth in various carbon sources

To analyze the effect of the Tr69957 deletion on the growth of $T$. reesei in various carbon sources, phenotypic assays for the parental and mutant strains were performed by inoculating of $10^{6}$ cells $/ \mathrm{mL}$ on minimal media (MM) and potato dextrose agar (PDA) plates containing
$1 \%$ of one of the following carbon sources: mannose, xylose, glucose, galactose, arabinose, raffinose, cellobiose sophorose, lactose, xylitol, glycerol, fructose, or maltose [29]. The experiment was performed in triplicates for each carbon source. The diameters of colonies were measured after 6 days.

\section{Quantitative real-time PCR analysis}

Trichoderma reesei mycelia were macerated and total RNA was extracted from each sample using TRIzol ${ }^{\circledR}$ RNA kit (Invitrogen Life Technologies, Carlsbad, CA, USA), according to the manufacturer's instructions. RNA concentration was determined using a spectrophotometer at an optical density ratio of $260 / 280 \mathrm{~nm}$, and RNA integrity was verified by electrophoresis in $1 \%$ agarose gels. To perform the expression analysis, initially, the total RNA $(1 \mu \mathrm{g})$ from each sample was digested with DNase I (Fermentas) to remove genomic DNA. Then, cDNA synthesis was carried out using the RevertAid H Minus First Strand cDNA Synthesis kit (Waltham, Massachusetts, USA) according to the manufacturer's instructions. Synthesized cDNA was diluted at 1:50 and used as a template for real-time PCR. Reactions were performed in the Bio-Rad CFX96 ${ }^{\mathrm{TM}}$ using SsoFast ${ }^{\mathrm{TM}}$ EvaGreen ${ }^{\circledR}$ Supermix (Bio-Rad) for detection according to the manufacturer's instructions. Each reaction mixture $(10 \mu \mathrm{L})$ contained $5 \mu \mathrm{L} \mathrm{SsoFast}{ }^{\mathrm{TM}}$ EvaGreen ${ }^{\circledR}$ Supermix (Bio-Rad), forward and reverse primers (500 $\mathrm{nm}$ each; Additional file 4), cDNA template, and nuclease-free water. PCR cycling conditions: $10 \mathrm{~min}$ at $95{ }^{\circ} \mathrm{C}(1 \mathrm{cycle}), 10 \mathrm{~s}$ at $95{ }^{\circ} \mathrm{C}$ followed by $30 \mathrm{~s}$ at $60{ }^{\circ} \mathrm{C}$ ( 40 cycles), and a melting curve of $60-95{ }^{\circ} \mathrm{C}$ with an increment of $0.5{ }^{\circ} \mathrm{C} / 10 \mathrm{~s}$ to check for primer dimers and nonspecific amplification. The transcript of the sar gene (encodes Sar1 GTPase from T. reesei) was used as an internal reference to normalize the amount of total RNA present in each reaction [30]. To perform gene expression analysis in strains grown on SCB, cellobiose, mannose, and xylose, the expression levels of genes were calculated from the threshold cycle according to the $2^{-\Delta C T}$ method [31] relative to transcription levels of sar. The experiment was repeated three times for each sample. The results were analyzed using $\mathrm{MeV}$ v.4.6.1. Software and heat maps were constructed to assess the variety in the expression of genes among the strains under each indicated condition.

\section{Construction of S. cerevisiae strain expressing T. reesei Tr69957}

The construction of $S$. cerevisiae strain that expresses $T$. reesei Tr69957 was performed as described by dos Reis et al. [44] using the EBY.VW4000 yeast strain (Additional file 1). Briefly, the T. reesei Tr69957 ORF was PCRamplified using cDNA obtained from the wild-type (WT) 
strain QM6A (Additional file 1) using specific primers $69957-\mathrm{F}$ and $69957-\mathrm{R}$. To perform in vivo recombination, the plasmid pRH195 was linearized by double digestion with SpeI and SalI, originating the pRH195m (pRH195 without XKS1 gene). The GFP gene was PCR amplified from pCMC17apx plasmid using primers pRH195 GFP_CS_F-yeast and spacerGFP 5'R_pRH195-yeast. Furthermore, the linearized plasmid was co-transformed with the PCR-amplified sugar transporter and GFP fragments into the S. cerevisiae EBY.VW4000 strain, which already contained the pRH27412 and pGH1x plasmids. The pRH274 plasmid contains the xylulose kinase $(X K)$, xylose reductase $(X R)$, and xylose dehydrogenase $(X D H)$ genes which encode enzymes of the xylose metabolic pathway while the pGH1 plasmid contains the $\beta$-glucosidase-encoding gene (gh1-1) from Neurospora crassa [32]. The yeast transformation was performed using the lithium acetate method [33]. Transformants were selected for tryptophan, leucine, and uridine prototrophy, and the yeast candidates were confirmed by PCR using the primers 69957-F and 69957-R. A list of all the primers used in this study can be accessed in Additional file 5.

Growth of S. cerevisiae strain on solid medium

Saccharomyces cerevisiae strains were inoculated in $50 \mathrm{~mL}$ YNB medium supplemented with $2 \%(\mathrm{w} / \mathrm{v})$ maltose for $48 \mathrm{~h}$ at $30^{\circ} \mathrm{C}, 200 \mathrm{rpm}$. Yeast cells were centrifuged at $4000 \mathrm{rpm}$ for $5 \mathrm{~min}$, washed three times with water, and re-suspended in water to a final concentration of 1.0 at $\mathrm{OD}_{600 \mathrm{~nm}}$. A serial dilution of 1:10 of the yeast cells was done, and $5 \mu \mathrm{L}$ of the cell suspensions were spotted on plates containing $1 \%(\mathrm{w} / \mathrm{v})$ of specific carbon source. Plates were incubated at $30^{\circ} \mathrm{C}$ for $120 \mathrm{~h}$.

\section{Microscopy}

Saccharomyces cerevisiae EBY.VW400 strain containing the Tr69957 gene tagged with GFP was grown for $48 \mathrm{~h}$ in $0.5 \mathrm{~mL}$ of liquid YNB-Trp-Ura-Leu medium supplemented with $2 \%(\mathrm{w} / \mathrm{v})$ maltose for $24 \mathrm{~h}$ at $30{ }^{\circ} \mathrm{C}$ in a well of 24-wells plate. Cells were washed with PBS and observed under a Carl Zeiss (Jena, Germany) microscope using the $100 \times$ magnification oil immersion objective lens (EC Plan-Neofluar, NA 1.3) equipped with a 100-W HBO mercury lamp epifluorescence module. Phase contrast bright-field and fluorescent images were acquired with an AxioCam camera (Carl Zeiss), and images were processed using the AxioVision software version 3.1 and saved as TIFF files.

3-D structure prediction and molecular docking

The 3D model for Tr69957 was built using the I-TASSER online platform from the Yang Zhang's Research Group
(https://zhanglab.ccmb.med.umich.edu/I-TASSER/). To this purpose, an FASTA file containing the amino-acid sequence for the referred protein was obtained from the UniProt database (gene: TRIREDRAFT_69957) and submitted to the I-TASSER online server. The structure modeling approach used by this software is based on the sequence alignment to a protein template, which is identified by LOMETS, a method that selects the top ten alignments in a PDB library. The unaligned regions of the sequence are built through ab initio folding, by considering the lowest free energy states and minimized sterical clashes that are identified by SPICKER and TM-align, respectively, and the final models are built at an atomic level by REMO which optimizes the hydrogen-bonding profile. In addition, the I-TASSER online software also allows the prediction of protein biological functions, as it compares the designed models to different libraries of proteins with previously identified functions $[34,35]$.

The docking analysis was performed using the software iGEMDOCK v. 2.1, a Generic Evolutionary Method for molecular DOCKing, developed by Jinn-Moon Yang (http://gemdock.life.nctu.edu.tw/dock/igemdock.php). It computes the interaction between one or more ligands with the active site of the target protein through empirical scoring function and an evolutionary approach algorithm. It also provides post-analysis tools by k-means and hierarchical clustering methods from the docked poses and the protein-ligand properties, such as atom composition and energy function [36-38].

To perform the docking analysis, structure of all the ligands was downloaded from the PubChem database (https://www.ncbi.nlm.nih.gov/pccompound) in MOL2 format. [lactose (CID 6134), maltose (CID 6255), mannose (CID 18950), xylose (CID 644160), cellobiose (CID 10712), and fructose (CID 5984)]. The PDB file for the model was uploaded to the iGEMDOCK software along with all the ligands, and the docking was performed using standard settings, with a population size of 200 and a total of 70 generations. The post-docking parameters were analyzed and the best docked pose for each ligand was visualized by The PyMOL Molecular Graphics System, Version 1.8.6.0 Schrödinger, LLC (https://pymol $. \operatorname{org} / 2 /)$.

\section{Results}

\section{Structural characterization of the transporter Tr69957}

The protein encoded by $\operatorname{Tr} 69957$ is described as a maltose permease according to the genome database of $T$. reesei, available in the JGI Genome Portal (http://genom e.jgi-psf.org/Trire2/Trire2.home.html). Considering all the parameters provided by the I-TASSER platform, the chosen model for the $\operatorname{Tr} 69957$ (Fig. 1a) was predicted based on the template 4ZWB.A [human glucose 
Capítulo I

transporter GLUT3 (N45T mutant) with bound D-glucose, outward-occluded conformation], which was determined by Deng et al. [39]. The predicted structure was considered to be adequate, as it presented a C-score of -0.80 and a TM-score of $0.61 \pm 0.14$. It also presented a root mean square deviation (RMSD) of $9.3 \pm 4.3$, and the cluster density was of 0.0938 for 1483 decoys (Additional file 6). The local accuracy results for the selected model (normalized B-factor) can be found in the Additional file 7. The structural motif described for $\operatorname{Tr} 69957$ (in red) (Fig. 1b) was conserved in several sugar transporters and may be involved with the specificity of the protein. The prediction of the Tr69957 structure by the TMRPres2D tool suggests that this transporter has 12 transmembrane domains, with a large extracellular loop and a relatively long central loop that is shared by many sugar transporters (data not shown). Phylogenetic analysis of Tr69957 with other fungal transporters indicated that $\operatorname{Tr} 69957$ shows high homology with disaccharide transporters, including the maltose permeases of $T$. harzianum, $T$. gamsii, Penicillium roqueforti, and S. cerevisiae (Fig. 1c).

\section{Tr69957 allows the growth of S. cerevisiae on various} carbon sources

To characterize the transporter $\operatorname{Tr} 69957$, we performed an analysis in which an S. cerevisiae strain EBY.VW4000, which lacks 20 distinct sugar transporters (but expresses $\mathrm{XK}, \mathrm{XR}, \mathrm{XDH}$, and $\beta$-glucosidase genes [32]), was $\mathrm{CO}^{-}$ transformed with the Tr69957 fused to the GFP. Fluorescence was predominantly observed on the yeast cell surface, suggesting that $\operatorname{Tr} 69957$ is located on the yeast plasma membrane (Fig. 2a). To verify the functionality of the Tr69957 in the S. cerevisiae strain EBY.VW4000, the complementary strain carrying the $\operatorname{Tr} 69957$ fused to the GFP was grown in the presence of maltose (positive control), cellobiose, xylose, and mannose. The drop-out

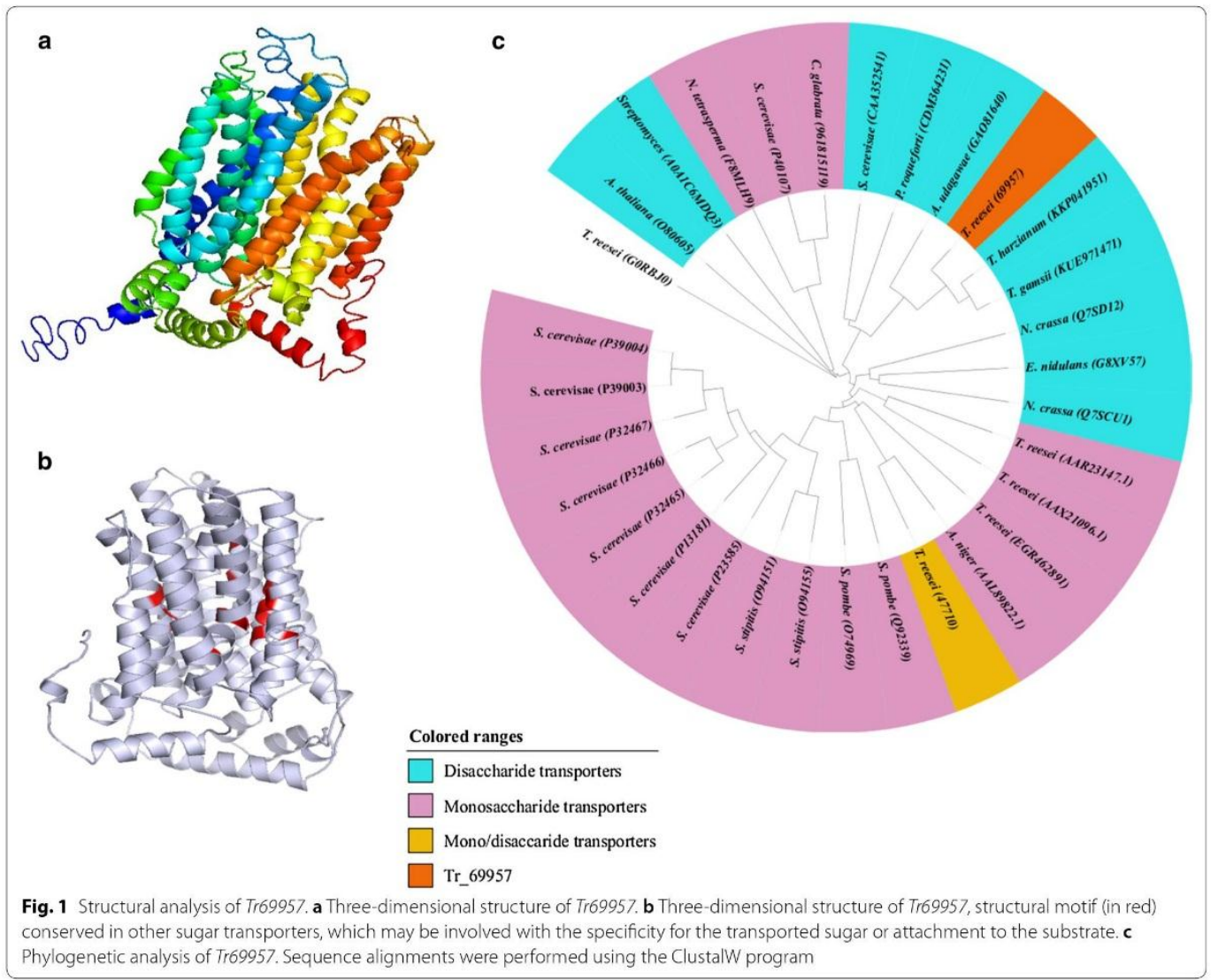


assay clearly showed that the expression of $\operatorname{Tr} 69957$ was able to restore the growth of EBY.VW 4000 on cellobiose, mannose, and xylose, suggesting that $\operatorname{Tr} 69957$ is able to transport these three different sugars (Fig. 2b). However, $\operatorname{Tr} 69957$ was not able to transport sophorose as expected (data not shown). The consumption of cellobiose, mannose, and xylose by the S. cerevisiae EBY.VW4000 and complemented strain expressing the $\operatorname{Tr} 69957$ fused to the GFP was also evaluated. Under the three analyzed conditions, the yeast that does not contain the $\operatorname{Tr} 69957$ was unable to transport the three carbon sources after 5 days of growth.

In contrast, the expression of Tr69957 completely restored the consumption of cellobiose, xylose, and mannose after $24 \mathrm{~h}$ (mannose) and $36 \mathrm{~h}$ (cellobiose and xylose) of growth (Fig. 2c-e). Altogether, these results suggest that $\operatorname{Tr} 69957 \mathrm{can}$ act as a monosaccharide as well as a disaccharide transporter in the yeast $S$. cerevisiae. a
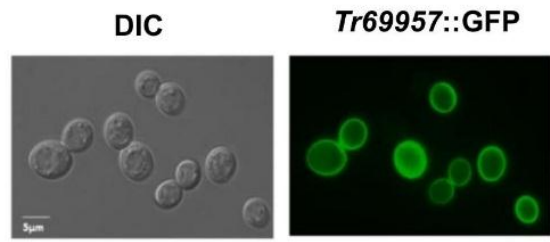

b

$\begin{array}{lllll}10^{7} & 10^{6} & 10^{5} & 10^{4} & 10^{3}\end{array}$

Tr69957::GFP

Control

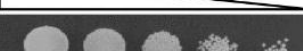

(1)
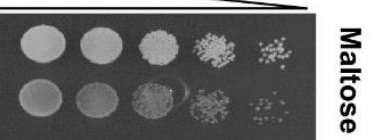

Tr69957::GFP

Control
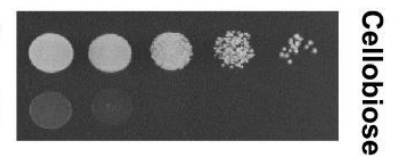

Tr69957::GFP

Control
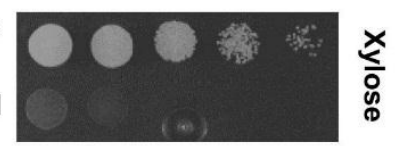

Tr69957::GFP

Control

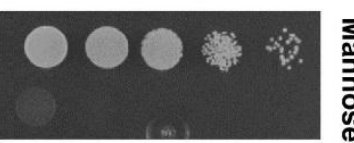

C

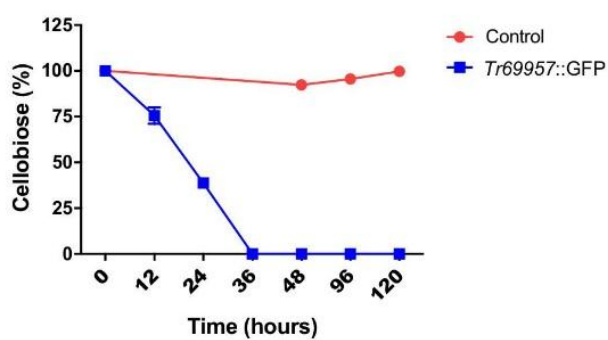

d

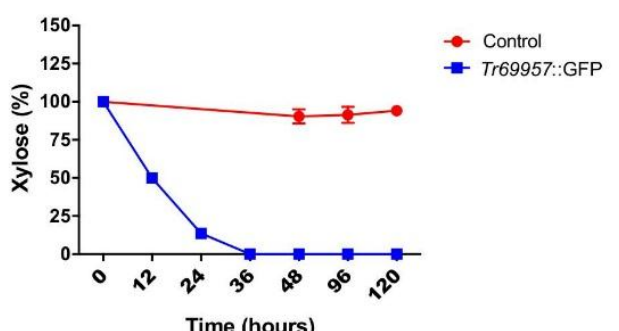

e

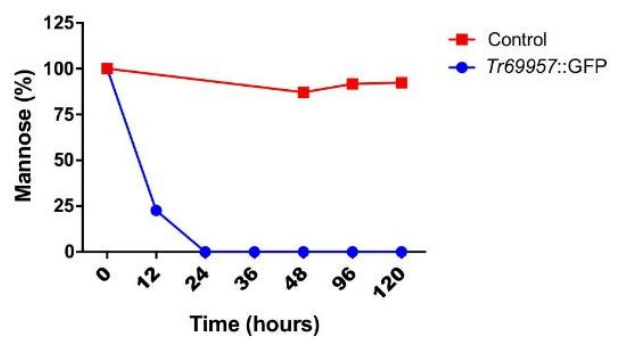

Fig. 2 Effect of Tr69957 transporter on growth of S. cerevisiae in the presence of cellobiose, mannose, and xylose. a Tr69957:GFP is localized in the plasma membrane in S. cerevisiae when grown in maltose-rich medium. Microscopy images were acquired in DIC and GFP fluorescence. $\mathbf{b}$ Growth of S. cerevisiae strain EBYVW4000 transformed with (Tr69957) and without (control) the transporter Tr69957 gene in the presence of $1 \%$ cellobiose, xylose, or mannose. Both the control and Tr69957 strains contained the genes encoding enzymes for xylose and cellobiose metabolic pathways. Yeast strains were initially grown in maltose-rich medium before a serial dilution was done (1:10 dilution, initial optical density $\left.\mathrm{OD}_{6000 \mathrm{~nm}}=1.0\right)$ and cells were incubated on plates containing the different carbon sources at $30^{\circ} \mathrm{C}$ for $96 \mathrm{~h} ; \mathbf{c}$ cellobiose, $\mathbf{d}$ xylose, and e mannose transport as determined by HPLC in the S. cerevisiae Tr69957 strain in the presence of $1 \%$ of the specific carbon source. S. cerevisiae strain which did not contain the Tr69957 transporter was used as the control strain. Standard deviations were obtained from triplicate assays 
Disruption of Tr69957 impairs the growth of T. reesei in the presence of monosaccharides and disaccharides Trichoderma reesei $\Delta 69957$ strain was constructed by homologous recombination using QM6a $\Delta$ tmus $53 \Delta$ pyr4 as the parental strain, whose non-homologous end joining pathway was disrupted [14]. Southern blot analysis of EcoRV-digested chromosomal DNA (Additional file 3) using the terminator region of $\operatorname{Tr} 69957$ gene as a probe resulted in expected results in parental (3391 bp) as well as $\Delta 69957$ (6698 bp) mutant strains, respectively (Additional file 3$)$.

After the disruption of $\operatorname{Tr} 69957$ transporter, we evaluated the ability of the $\Delta 69957$ mutant strain to grow in the presence of various carbon sources (Fig. 3). For this purpose, the parental and mutant strains were grown on MM plates in presence of D-glucose, D-fructose, D-mannose, D- $(+)$ cellobiose, lactose, PDA, D- $(+)$-raffinose, L-arabinose, raffinose, glycerol, D-xylose, or xylitol as the sole carbon-source. The $\Delta 69957$ mutant strain exhibited a decreasing radial growth in the presence of mannose, xylose, cellobiose, lactose, and fructose (Fig. 3a, b). Our results suggest that the transporter 69957 has a key role in the metabolism of monosaccharides such as mannose, xylose, and fructose, and disaccharides such as cellobiose and lactose, suggesting a promiscuous mechanism involved in the transport of sugar into the cell.

\section{Tr69957 presents lower protein-ligand free energy} in interactions involving disaccharides than that in the monosaccharides

To understand the preference of sugars transported by Tr69957, we performed a docking analysis. The selection of the most adequate model relies on the confidence scores: $\mathrm{C}$-score and TM-score. The $\mathrm{C}$-score estimates the quality of the prediction, for which the higher the value, the higher is the confidence. The TM-score latter measures the structural similarity between the predicted model and the template used for its construction. The values $>0.5$ demonstrate a correct topology, whereas values $<0.17$ demonstrate a random similarity. RMSD also represents the similarity of the predicted structure to the template, although it may show a very high value due to local errors, even if the model is adequate. The three scores are highly correlated to one another.

Considering all the parameters provided by the I-TASSER platform, the chosen model for the Tr69957 was predicted based on the template 4ZWB.A [human glucose transporter GLUT3 (N45T mutant) with bound D-glucose, outward-occluded conformation], determined by Deng et al. [39]. The predicted structure was considered adequate, since it presented a C-score of -0.80 , TM-score of $0.61 \pm 0.14$, and an RMSD of $9.3 \pm 4.3$.
The PDB file obtained for the $\operatorname{Tr} 69957$ was used for the docking analysis and the results were post-analyzed based on the total free energy, as well as the Van der Waals, hydrogen, and electrostatic interactions (Table 1) for each ligand. Lactose is the carbohydrate with the most favorable binding (Fig. 4c) and xylose (Fig. 4f) with the most unfavorable binding (Fig. 4) when the rigid structure of the protein, but with the adequate ligand flexibility was considered. The complete interaction profiles can be found in the Additional file 8 .

These results show that the $\operatorname{Tr} 69957$ sugar transporter is able to transport several types of carbohydrates, preferentially disaccharides, such as lactose, cellobiose, and maltose in which the molecules showed the lowest free energies, and thus, the highest binding affinity to the protein (Table 1). With respect to the monosaccharides, fructose (Fig. 4b), mannose (Fig. 4e), and xylose (Fig. 4f), even though these exhibited higher free energy than the disaccharides, they still possess adequate binding affinity, suggesting that the conformational changes the protein may suffer are adaptive to the distinct carbon sources in the environment (Table 1).

\section{Disruption of Tr69957 Impairs the Fungal Biomass}

\section{Accumulation and the Sugar Uptake}

The early gene expression experiments performed to characterize the Tr69957 sugar transporter were done using SCB, a complex lignocellulosic biomass. Similar to other plant cell walls, SCB is mainly formed by two carbohydrate fractions (cellulose and hemicellulose) embedded in a lignin matrix. The hydrolysis of SCB releases a range of sugars, such as mannose, xylose, cellobiose, and fructose that can be used by the fungus for energy production. As demonstrated in Fig. 3a, b, the $\Delta 69957$ mutant strain showed an impaired growth in the presence of all these sugars released from SCB hydrolysis. In this way, for the next set of experiments for characterization of $\operatorname{Tr} 69957$, we selected three out of the four sugars that presented significant variations during the growth conditions of the mutant strain.

The deletion of the sugar transporter-encoding $\operatorname{Tr} 69957$ resulted in reduced fungal biomass accumulation in the presence of mannose (Fig. 5a) and cellobiose (Fig. 5b), which does not occur in the presence of xylose (Fig. 5c). Interestingly, our results showed that the deletion of sugar transporter $\operatorname{Tr} 69957$ altered the uptake kinetics of mannose, cellobiose, and xylose in T. reesei in comparison with that of $S$. cerevisiae. In regards to mannose, we identified that this sugar is completely consumed by the parental strain after $24 \mathrm{~h}$ of cultivation (Fig. 5d). Conversely, in the $\Delta 69957$, this monosaccharide was only partially consumed after $48 \mathrm{~h}$ of cultivation (Fig. 5d). The same profile was observed for the uptake 


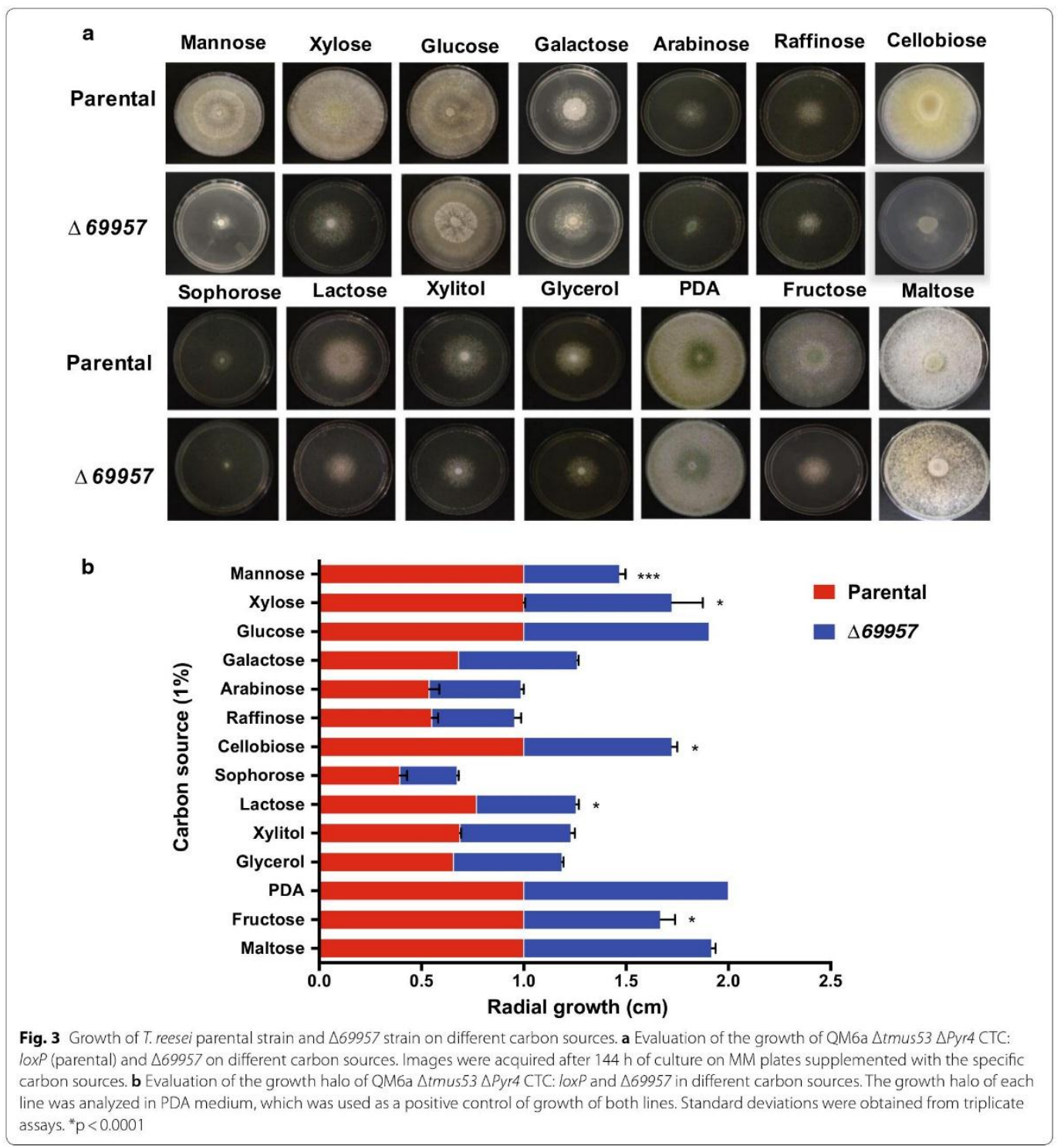

kinetics of cellobiose (Fig. 5e). However, we observed that xylose uptake showed a slight difference in the mutant strain as compared to the parental strain. Our results showed that the xylose content was completely exhausted in parental and mutant strain only after $48 \mathrm{~h}$ of cultivation (Fig. 5f). In addition, we also observed that uptake kinetics for all the sugars was faster in the parental strain as compared to that in the $\Delta 69957$ mutant strain, which showed a delay in the sugar consumption (Fig. $5 \mathrm{c}, \mathrm{d}, \mathrm{f}$ ). Together, these results suggest that there is a delay in the attainment of mannose, cellobiose, and xylose in the mutant strain. In addition, our results showed that $\operatorname{Tr} 69957$ is important for the recognition and transport of mannose, cellobiose, and xylose, and probably, different 
Table 1 Tr_69957 interactions with different sugars analyzed by docking based on the total free energy, the Van der Waals, hydrogen, and electrostatic interaction for each ligand

\begin{tabular}{llll}
\hline Interaction & Energy $(\mathrm{KJ} / \mathrm{mol})$ & VDW & H bonds \\
\hline Tr69957::cellobiose & -108.48 & -66.3 & -44.8 \\
Tr69957::fructose & -81.47 & -52.9 & -28.5 \\
Tr69957::maltose & -101.8 & -59.3 & -42.5 \\
Tr69957::mannose & -80.34 & -37.18 & -43.15 \\
Tr69957::xylose & -77.12 & -27.8 & -49.3 \\
Tr69957::lactose & -114.71 & -83.05 & -31.6 \\
\hline
\end{tabular}

mechanisms could control the uptake of these sugars in T. reesei.

To test this hypothesis, we evaluated the consumption of these sugars during the cultivation by the addition of the three sugars in the same culture (Fig. 6). The results demonstrated that mannose is the first sugar to be consumed in the parental strain, followed by xylose and cellobiose. In the $\Delta 69957$ mutant strain, we observed a distinct profile of sugar consumption, mannose being the first sugar consumed after $48 \mathrm{~h}$ of cultivation followed by cellobiose and xylose. In this way, our results showed a delay in the consumption of xylose in the mutant strain as compared to the parental strain Furthermore, we also observed that at $6 \mathrm{~h}$, the mutant strain cannot consume mannose in a similar manner to that by the parental strain. After $24 \mathrm{~h}$, approximately $60 \%$ of the sugars were consumed by the mutant strain, while in the parental strain, all the sugars present in the medium had already been consumed (Fig. 6). However, the profile of the cellobiose consumption appeared to be different with respect to the parental and mutant strains when compared to the other carbon sources that were analyzed. The mutant strain 69957 presented a cellobiose consumption about 1.3 times higher than the parental strain after $24 \mathrm{~h}$ of culture, whereas this rate persisted until $48 \mathrm{~h}$ (Fig. 6), suggesting that the more rapid consumption of cellobiose may well result from the increased hydrolysis by $\beta$-glucosidases in the absence of $\operatorname{Tr} 69957$.

\section{Tr69957 affects cellulolytic and hemicellulolytic gene} expression in T. reesei

Since the deletion of Tr69957 affected the fungal growth and sugar consumption, we evaluated the gene expression profile of six cellulases and hemicellulases in the presence of SCB, cellobiose, mannose, and xylose during 6,24 , and 48 h of incubation of the parental and mutant

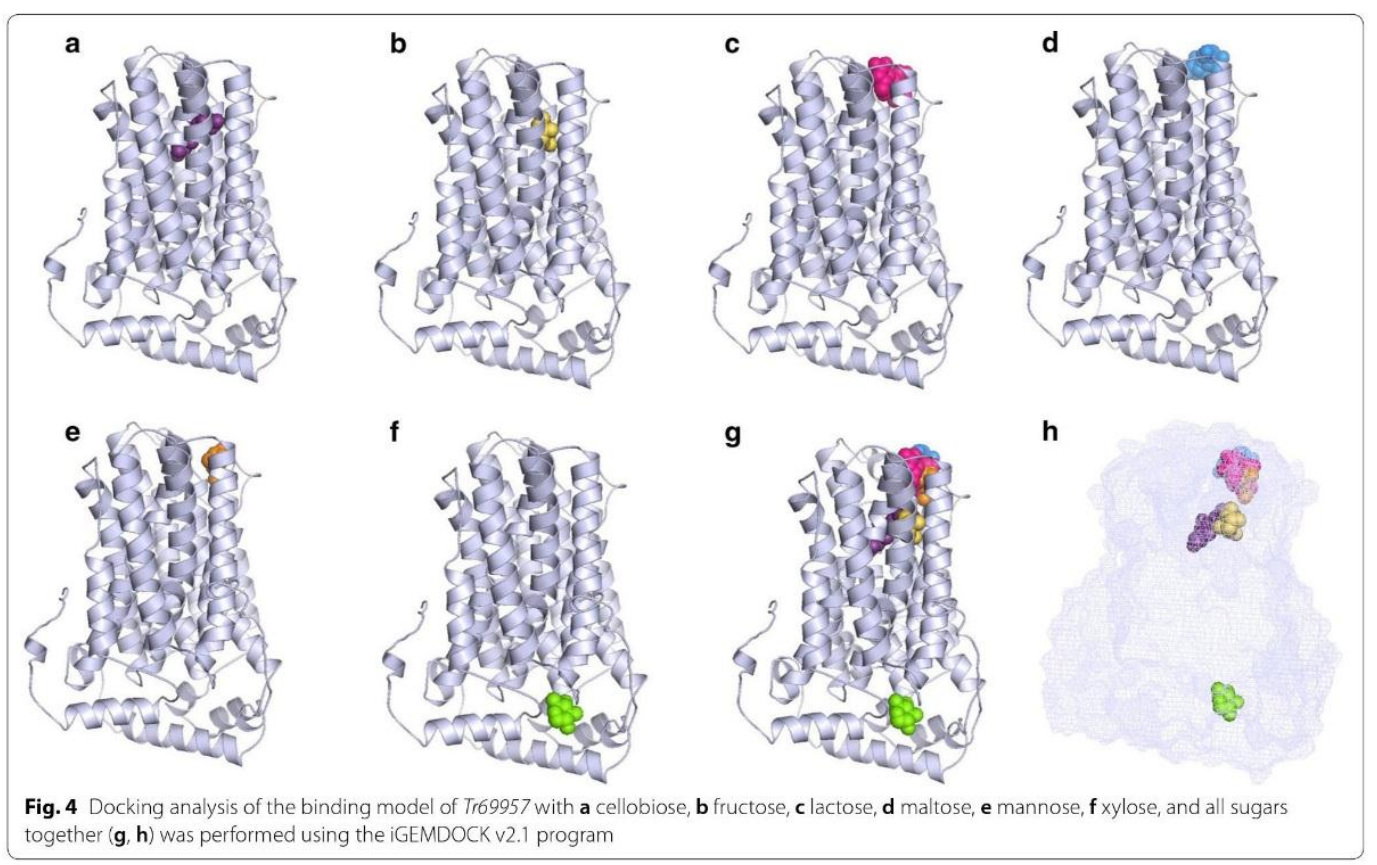




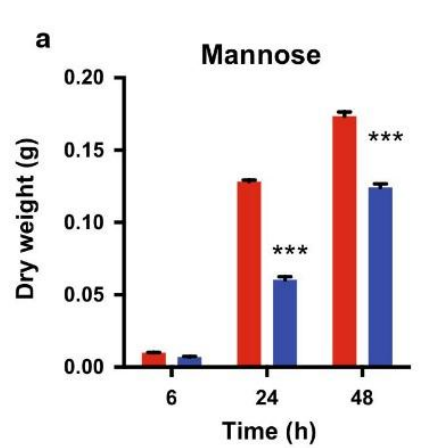

b
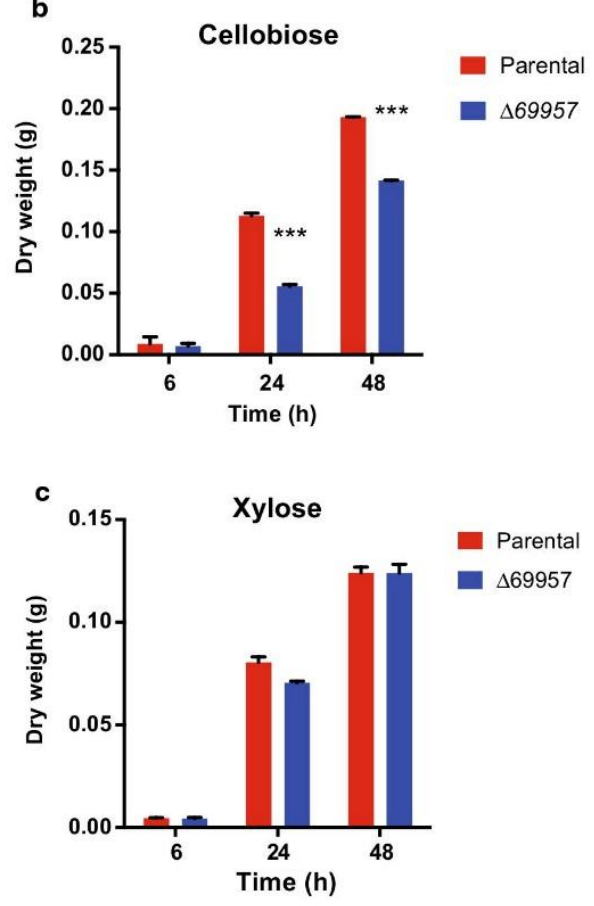

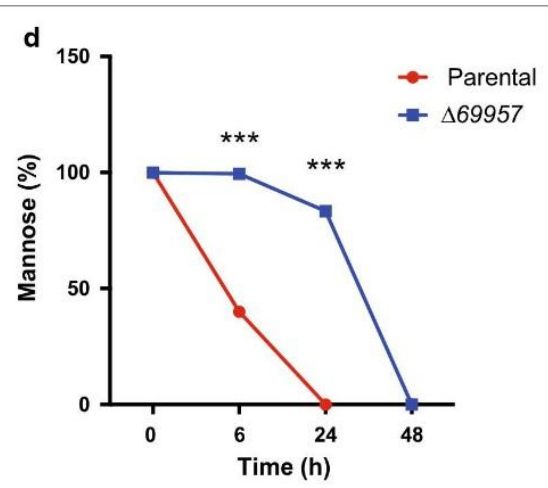

e
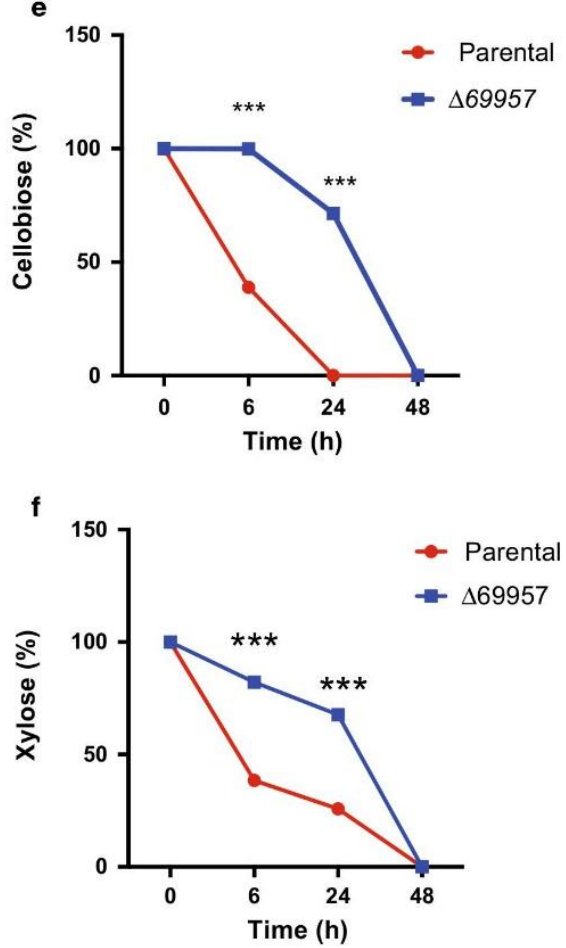

Fig. 5 Tr69957 disruption decreases the growth and consumption of mannose, cellobiose and xylose in T. reesei strain. Analysis of the biomass and sugar consumption of parental and mutant strains under culture in MAM supplemented with mannose (a, d), cellobiose (b,e), and xylose (c, $\mathbf{f})$, during growth for $0,6,24$, and $48 \mathrm{~h}$ in the presence of $1 \%$ mannose, cellobiose, or xylose. Standard deviations were obtained from triplicate assays. ${ }^{*} \mathrm{p}<0.0001$ 


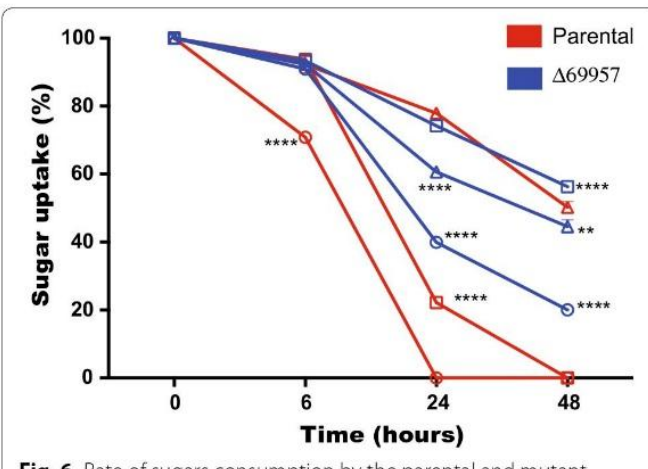

Fig. 6 Rate of sugars consumption by the parental and mutant strains during culture in MAM supplemented with mannose (white circle), xylose (white square), and cellobiose (white triangle), for 0 , 6,24 , and $48 \mathrm{~h}$ growth in the presence of $30 \mathrm{mM}$ of each sugar. Standard deviations were obtained from triplicate assays. ${ }^{*} p<0.0001$

strains. In addition, the expression of $\operatorname{Tr} 69957$ was also evaluated (Fig. 7).

After $48 \mathrm{~h}$ of growth, the highest expression of $\operatorname{Tr} 69957$ was achieved in the presence of cellobiose. Under similar conditions, deletion of $\operatorname{Tr} 69957$ resulted in a drastic decrease in the expression of cel7a, cel6a, and cel3a in the mutant strain, whereas cella and xyn 2 were less expressed in the parental QM6a (Fig. 7). In the presence of mannose and xylose, the transporter Tr69957 was less expressed in comparison with that in the other conditions. In both carbon sources, the cella was the most affected gene with the $\operatorname{Tr} 69957$ deletion, being more expressed in the parental QM6a when compared to the mutant strain after $24 \mathrm{~h}$ of cultivation (Fig. 7).
The growth in SCB showed the highest expression of Tr69957 among all the tested conditions, with maximum expression at $6 \mathrm{~h}$ of growth. In SCB, the expression of cel7a and cel6a was decreased in the mutant $\Delta 69957$ in comparison with the parental strain in the first few hours of growth. Interestingly, after $48 \mathrm{~h}$, the deletion of $\operatorname{Tr} 69957$ resulted in increased expression of all the cellulolytic and hemicellulolytic genes analyzed in the mutant strain (Fig. 7). Figure 7 shows that cella and cel3a were significantly induced in $\Delta 69957$ in the presence of sugarcane bagasse after 24 and $48 \mathrm{~h}$ when compared to the WT strain in the same conditions. This result is in accordance with the assumption that the absence of $\operatorname{Tr} 69957$ promotes faster consumption of cellobiose due to the increased hydrolysis by $\beta$-glucosidases in the presence of mixture of carbon sources like mannose, cellobiose, and xylose, which also compose the sugarcane bagasse.

\section{Discussion}

The fungus $T$. reese $i$, in the absence of simple sugars as carbon sources, secretes extracellular lignocellulolytic enzymes, which can degrade biomass through a natural process [1, 40]. Thereafter, the degraded simple sugars can be assimilated for cell metabolism. In this process transporters are the key role players in T. reesei to sense and utilize sugars [7, 29]. Most transporters encoded by filamentous fungi have not yet been characterized. Therefore, studying the function of transporters will provide new insights to understand the sensing mechanism in T. reesei. This study will enable us to better understand the gene expression pattern of cellulolytic enzymes produced by this fungus, which can contribute to the performance of it in the bioethanol industry. In this study, we

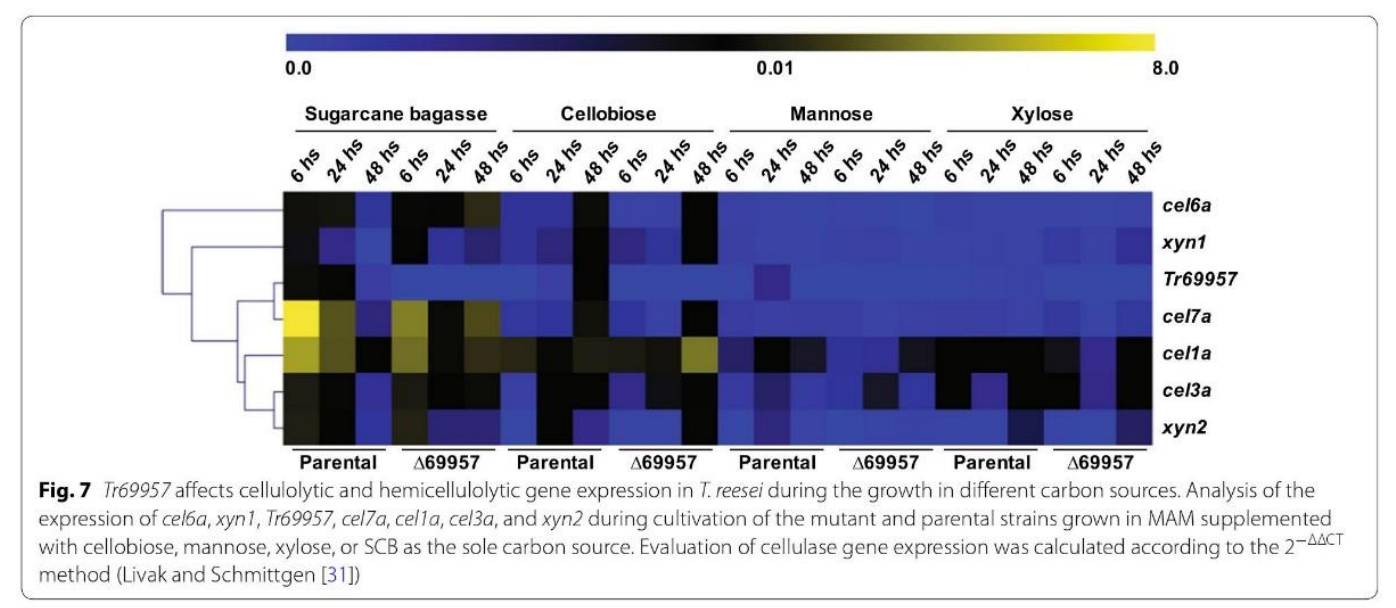


characterized a putative sugar transporter $\operatorname{Tr} 69957$ that was previously identified by our group using RNA-seq data, which is important for xylose, cellobiose, and mannose utilization in T. reesei. To the best of our knowledge, this is the first report of a potential mannose transporter and its involvement in the degradation process of cellulose in the filamentous fungus $T$. reesei.

For better demonstration of the phenomenon that Tr69957 is able to transport specific sugars, the S. cerevisiae strain EBY.VW4000 [13] was used. The S. cerevisiae strain (EBY.VW4000) lacks the hexose transport activity due to the deletion of 20 hexose transporter genes and is unable to grow on glucose, fructose, mannose, or galactose as the sole carbon source. The hexose transport-deficient $S$. cerevisiae strain (EBY.VW4000) has been an important tool for characterizing new hexose transporters of other fungi, such as HXTB [41] and RhtA [42] from A. niger, and the TBHXT1 [43] transporter from the ascomycete Tuber borchii. Using this $S$. cerevisiae strain, we can prevent interference from other sugar transporters that were already described in $T$. reesei. The yeast experiments suggest that $\operatorname{Tr} 69957$ has the capability of transporting a few sugars, including cellobiose, mannose, and xylose. Therefore, Tr69957 can transport more than one sugar, which is not surprising because the filamentous fungi are able to internalize a wide variety of mono- and oligosaccharides and it has already been shown that transporters expressed by them can often transport more than one type of sugar [8].

Our data showed that $\operatorname{Tr} 69957$ probably participated in the transport of cellobiose, mannose, xylose, lactose, galactose, and fructose in T. reesei, as $\Delta \operatorname{Tr} 69957$ strain displayed growth defects on these carbon sources. However, the docking results showed that $\operatorname{Tr} 69957$ exhibits lower protein-binding energy in interactions involving disaccharides compared to the monosaccharides, suggesting a better orientation and affinity between these molecules.

The absence of transporter specificity can be explained by the similarity in the structures of some of the sugar molecules. Furthermore, some of these proteins can act as transporters as well as nutrient sensors [44]. Substrate transport requires binding and subsequent conformational change. After binding of the substrate, MFS transporters go through a series of conformational changes [45]. Many residues in MFS transport structures are involved in substrate uptake [46]. Besides substrate binding and specific conformational changes, the transporter domains function as gates that influence the substrate specificity [47]. Structurally, similar substrates can bind to the transporter; however, they cannot induce the conformational change, leading to inhibition of transport; for example, D-glucose can competitively inhibit D-xylose transporters as they share similarity in their structures
[48]. However, interesting exceptions have been discovered in few $A$. niger sugar transporters, which sugges that if the binding occurs without subsequent conformational change, then the alternative substrate will be transported across the membrane [49].

Conversely, the absence of specificity can be advantageous when fungi encounters complex lignocellulosic material, which contains multiple hexoses and pentoses [11]. The fungi can exhibit differences and similarities in response to different lignocellulosic substrates $[1,50,51]$.

In Fig. 6, we observed that when a mixture of mannose, cellobiose, and xylose is present, the parental strain consumes in the order of mannose, xylose, and cellobiose. Despite the molecular docking results showing that Tr69957 exhibits more affinity towards cellobiose than towards mannose and xylose, the presence of these sugars can cause reduction of cellobiose uptake. Similar results were observed in MstG and MstH A. niger sugar transporters. Both transporters showed high specificity for glucose. However, some sugars like galactose, fructose, and xylose were able to inhibit MstG glucose transport by 39 , 29 , and $25 \%$, respectively; in the MstH transformants, the presence of mannose and fructose reduced the uptake of labeled glucose by 70 and $50 \%$, respectively [52]. Moreover, in $A$. niger, substrate specificity of hexose transporters $\mathrm{HxtB}$ and $\mathrm{HxtC}$ showed a reduction in glucose uptake by $70-80 \%$ in presence of galactose, fructose, and mannose [48]. In the mutant strain, we can observe a different pattern of sugar consumption, where mannose is consumed first, then cellobiose and xylose at last, in addition to having higher cellobiose consumption than the parental strain under the similar conditions. Similar results were found in case of STP1, a T. reesei cellobiose transporter mutant strain. In comparison with the WT, cellobiose in the culture supernatant of STP1 mutant was consumed at a much faster rate [8]. However, the same does not occur when we culture the $\Delta 69957$ mutant strain containing only cellobiose as the sole source of carbon (Fig. 4d). We believe that in the presence of these three sugars or in complex carbon sources, for example, lignocellulosic material, a specific response occurs in the absence of $\Delta 69957$, although the exact mechanism awaits further elucidation. We suppose that, in the presence of $\operatorname{Tr} 69957$, mannose and xylose, which are present in the hemicellulosic portion, somehow signal the presence of cellulose in the environment when transported at first. This transporter could be dependent on an early and late signaling mechanism in response to lignocellulosic biomass. The hemicellulose polymer includes xylan, glucuronoxylan, arabinoxylan, glucomannan, and xyloglucan. In addition, these polysaccharides contain many different sugar monomers such as xylose, arabinose, mannose, glucose, galactose, and rhamnose, being xylose the most abundant one 
Capítulo I

in most of the cases, although sometimes, mannose can be the most abundant sugar $[53,54]$ (Fig. 8). The polysaccharides found in the hemicellulose structure can be hydrolyzed by xylanases and mannanases releasing xylose and mannose, respectively, that in turn could be transported into the cell. In our model, we believe that $\operatorname{Tr} 69957$ may sense the presence of mannose in the extracellular compartment and the transport of mannose into intracellular milieu would in turn activate the cellulases expression in an early signaling involving this sugar transport (Fig. 8black arrows). Here, we consider that $\operatorname{Tr} 69957$ can act as a potential mannose transporter, which could be involved in the degradation process of cellulose in T. reesei.
Concomitantly, in a second instance, in response to early signaling, Tr69957-mediated cellulase expression and secretion of CAZymes could act by cleaving cellulose to release disaccharides, such as cellobiose, that in turn might get internalized promoting a late signaling response, increasing the expression of cellulases in the presence of cellulose (Fig. 8-red arrows). Furthermore, as observed in Fig. 7, in the presence of mannose, the expression of $\beta$-glucosidase is higher than that of other cellulases, indicating that mannose present in the environment might signal the expression of these enzymes, which act in the conversion of cellobiose to sophorose [55], thereby increasing the cellulase expression during the late signaling of $\operatorname{Tr} 69957$.

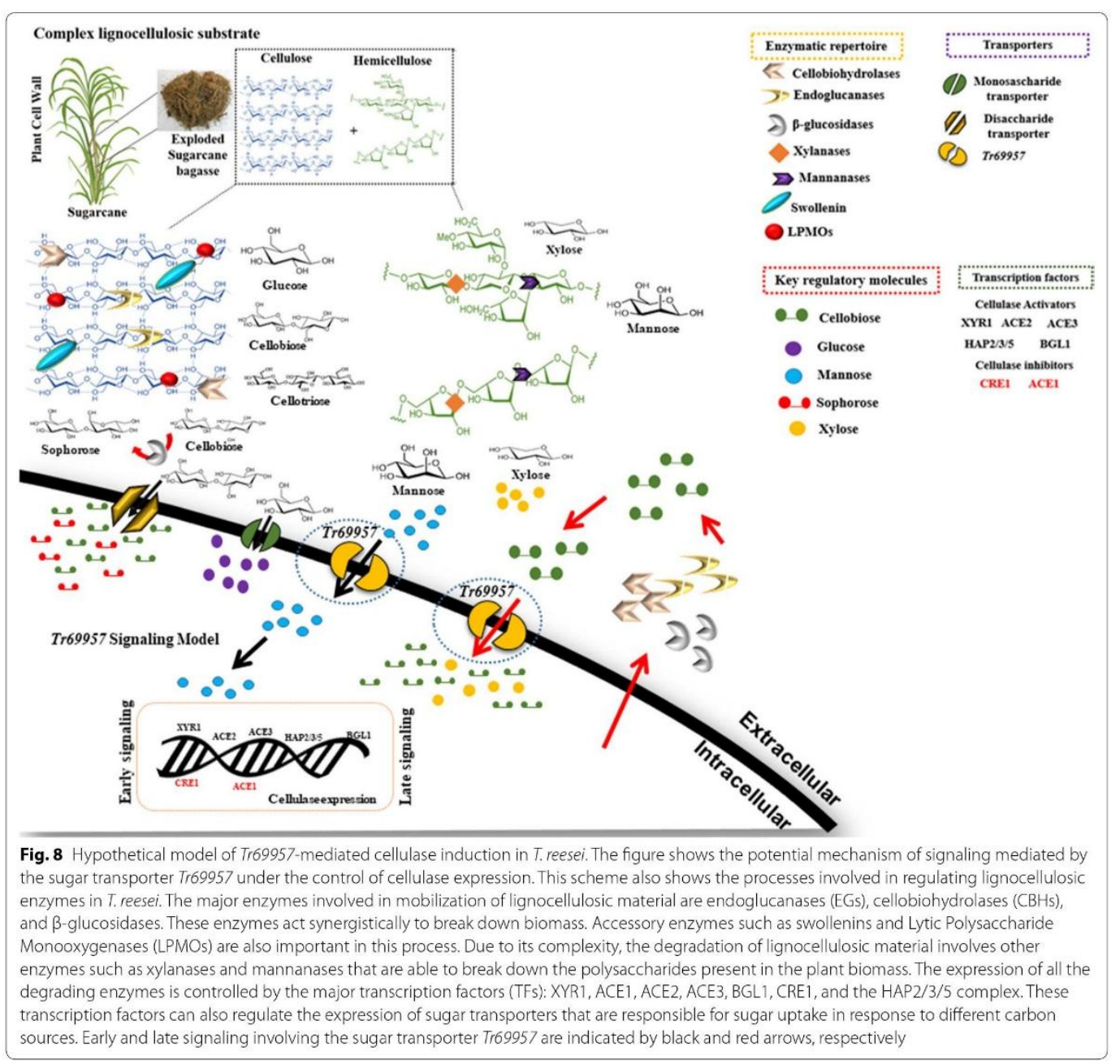


Capítulo I

In this study, we characterized a cellobiose, mannose, and xylose transporter involved in SCB degradation in T. reesei. The study also suggests that the transporter is associated with early and late signaling in the presence of lignocellulosic biomass. Taken together, these data contribute to the studies addressing the mechanism of action by which T. reesei senses the cellulose signal. The present study explores the mechanism of sensing and transportation of sugars in $T$. reesei, which are important and relevant during the application of this fungus in bioethanol production.

\section{Conclusion}

The present study aimed to improve our understanding of the sugar transport systems, through characterization of a novel sugar transporter involved in the degradation of lignocellulosic biomass in T. reesei. In addition, this study will aid in understanding the influence of this transporter on metabolic signaling and induction of the cellulase genes, which will subsequently have effect on lignocellulose degradation.

Our results showed that the transporter $\operatorname{Tr} 69957$ of $T$. reesei can transport cellobiose, xylose, and mannose, and can affect the expression of a few genes encoding enzymes, such as cellulases and xylanases, in the presence of SCB. Moreover, our study is the first report that shows a potential role for a mannose transporter in the regulation of cellulase genes in $T$. reesei in the presence of SCB. These results suggest that $\operatorname{Tr} 69957$ can be important during the signaling of cellulase gene expression. These findings contribute to the understanding of the molecular mechanisms involved in the regulation of the processes of cellulolytic enzyme synthesis and signaling.

\section{Additional files}

Additional file 1. Strains and plasmids used in this work.

Additional file 2. Oligonucleotides used for pyrG amplification, promoter region and terminator region of 69957.

Additional file 3. Southern blot analyse to confirm deletion of Tr69957 in T. reesei. (A) Strategy used to confirm deletion of Tr69957 by Southern in Tri (A) Stragy blot. The figure shows the promer purple) of the gene, with the substitution of the ORF by the pyrG selection marker. A specific DNA probe was created to bind the portion of the gene (in blue), confirming its presence in the analyzed genetic content. (B) Southern blot showing the parental fungus (QM6a $\Delta t$ tmus $53 \Delta p y r 4$ ) used as control and four deleted candidates that did not present detection of the gene portion equivalent to $3391 \mathrm{bp}$ as in the parental and presented the region corresponding to $6698 \mathrm{bp}$, confirming the deletion

Additional file 4. Oligonucleotides used for evaluation of gene expression.

Additional file 5. Oligonucleotides used for complementation in S. cerevisiae.

Additional file 6. SCORING FUNCTIONS: the global accuracy for the five designed candidates. The chosen structure was the Model 1, which was predicted based on the 4ZWB.A (human GLUT3 glucose transporter (N45T mutant) with bound D-glucose, outward-occluded conformation) determined by Deng et al. [39], since it presents not only the highest valu for C-score, but also satisfactory values for the TM-score and the RMSD, also being the largest cluster. C-score: the confidence of the construction essentially based on the template alignments and the parameters for assembling the structure, whereas the higher the value, the higher the confidence and quality. TM-Score and RMSD: the similarity between the designed model and the template used, being less and more sensitive to local error, respectively. TM-score $>0.5$ indicates a correct topology. Number of decoys: the amount of conformations generated by the software. Cluster density: the size of the clusters formed for each model, whereas the larger the cluster, the lowest the free energy of the model.

Additional file 7. LOCAL ACCURACY: the divergence of the modeling represented by the distance $(\mathcal{A})$ between the protein designed and the template used for the construction of it. RES: residue number; SS: predicted secondary structure (C: random coil, $\mathrm{H}$ : alpha-helix, S: beta-strand; SA: predicted solvent accessibility at 25\% cutoff (E: exposed, B: buried); COV: alignment coverage; BFP: predicted normalized B-factor; RSQ_1: COV: alignment coverage; BFP: predicted normalized B-factor; RSQ_1:
Residue-Specific Quality of the template (the estimated deviation of the residue on the template from the built protein)).

Additional file 8. INTERACTION PROFILE: the detailed amount of energy required for each atom in the protein to interact with each one of the ligands, through hydrogen bonding $(H)$ and Van der Waals contact $(V)$.

\section{Authors' contribution}

KMVN performed the experimental design, laboratory experiments, and drafted the manuscript. RGP, ACCA, and TF dos Reis performed laboratory experiments and drafted the manuscript. CBC performed 3D structure prediction and molecular docking, and drafted the manuscript. ACS and MSB performed laboratory experiments. FBRA performed 3D structure prediction. CGVR performed the experimental design with HPLC experiments. GHG performed the experimental design. RNS designed the project, supervised the research study, prepared/drafted the manuscript, and approved the final version to be published. All authors have read and approved the final manuscript.

\section{Author details}

${ }^{1}$ Department of Biochemistry and Immunology, Ribeirāo Preto Medical School, University of São Paulo, Ribeirăo Preto, SP, Brazil. ${ }^{2}$ Department of Pharmaceutical Sciences, Faculty of Pharmaceutical Sciences of Ribeirão Preto, University of São Paulo, Ribeirão Preto, SP, Brazil.

\section{Acknowledgements}

We would like to thank the Fundação de Amparo à Pesquisa do Estado de São Paulo (FAPESP) (Processes FAPESP 2015/09553-8) for supported this work. Dr. Eckardt Boles for providing the EBY.VW4000 yeast strain. We are grateful to the laboratory techniques Luciana Angolo Faria Rocha, Zuleica Aparecida Soares de Moraes and Silvia Helena Castrechini Brito.

Competing interests

The authors declare that they have no competing interests.

\section{Availability of data and materials}

All data generated or analyzed during this study are included in this published article and its Additional files 1, 2, 3, 4, 5, 6,7 and 8 .

Ethics approval and consent to participate

This study needed no ethical approval and had no experimental research on humans.

Funding

This work was supported by the Fundação de Amparo à Pesquisa do Estado de São Paulo (FAPESP) (Processes FAPESP 2015/09553-8).

\section{Publisher's Note}

Springer Nature remains neutral with regard to jurisdictional claims in published maps and institutional affiliations. 
Capítulo I

Received: 15 January 2018 Accepted: 17 March 2018

Published online: 02 April 2018

References

1. Daly P, van Munster JM, Raulo R, Archer DB. Transcriptional regulation and responses in filamentous fungi exposed to lignocellulose. In: Silva RN, editor. Fungal biotechnology for biofuel production. Sharjah: Bentham editor. Fungal biotechno

2. Martinez D, Berka RM, Henrissat B, Saloheimo M, Arvas M, Baker SE, et al. Genome sequencing and analysis of the biomass-degrading fungus Trichoderma reesei (syn. Hypocrea jecorina). Nat Biotechnol. 2008:26:553-60.

3. Castro LDS, Antoniêto ACC, Pedersoli WR, Silva-Rocha R, Persinoti GF, Silva RN. Expression pattern of cellulolytic and xylanolytic genes regulated by transcriptional factors XYR1 and CRE1 are affected by carbon source in Trichoderma reesei Gene Expr Patterns. 2014:14:88-95.

4. Häkkinen M, Arvas M, Oja M, Aro N, Penttilä M, Saloheimo M, et al. Reannotation of the CAZy genes of Trichoderma reesei and transcription in the presence of lignocellulosic substrates. Microb Cell Fact. 2012;11:134

5. Gusakov AV. Alternatives to Trichoderma reesei in biofuel production. Trends Biotechnol. 2011;29:419-25.

6. Ragauskas AJ, Williams CK, Davison BH, Britovsek G, Caimey J, Eckert $\mathrm{CA}$, et al. The path forward for biofuels and biomaterials. Science. 2006;311:484-9.

7. Sloothaak J, Antonio J, Ramos T, Odoni DI, Laothanachareon T, Dernt C et al. Biotechnology for Biofuels Identification and functional characterization of novel xylose transporters from the cell factories Aspergillus niger and Trichoderma reesei. Biotechnol Biofuels. 2016;9:148

8. Zhang W, Kou Y, Xu J, Cao Y, Zhao G, Shao J, et al. Two major facilitator superfamily sugar transporters from Trichoderma reesei and their roles in induction of cellulase biosynthesis. J Biol Chem. 2013;288:32861-72.

9. Ries L, Pullan ST, Delmas S, Malla S, Blythe MJ, Archer DB. Genome-wide transcriptional response of Trichoderma reesei to lignocellulose using RNA sequencing and comparison with Aspergillus niger. BMC Genom. 2013;14:141.

10. Fernanda T, Borborema P, De Lima A, Parachin NS, Mingossi FB, Velasco $\mathrm{J}$, et al. Biotechnology for biofuels identification and characterization of putative xylose and cellobiose transporters in Aspergillus nidulans. Biotechnol Biofuels. 2016;9:204

11. Colabardini AC, Nicolas L, Ries A, Brown NA, Fernanda T, Savoldi M, et al. Functional characterization of a xylose transporter in Aspergillus nidulans. Biotechnol Biofuels. 2014;7:46.

12. Zhang W, Kou Y, Xu J, Zhao G, Shao J, Wang H, et al. Microbiology: two major facilitator superfamily sugar transporters from Trichoderme reesei and their roles in induction of cellulase biosynthesis. J Biol Chem. 2013:288:32861-72.

13. Wieczorke R, Krampe S, Weierstall T, Freidel K, Hollenberg CP, Boles E. Concurrent knock-out of at least 20 transporter genes is required to block uptake of hexoses in Saccharomyces cerevisiae. FEBS Lett. 1999;464:123-8.

14. Derntl C, Kiesenhofer DP, Mach RL, Mach-Aigner AR. Novel strategies for genomic manipulation of Trichoderma reesei with the purpose of strain engineering. Appl Environ Microbiol. 2015;81:6314-23.

15. Schmoll M, Schuster A, Silva RDN, Kubicek CP. The G-alpha protein GNA3 of Hypocrea jecorina (anamorph Trichoderma reesei) regulates cellulase gene expression in the presence of light. Eukaryot Cell. 2009:8:410-20.

16. Souza D, De Souza WR, De Gouvea PF, Savoldi M, Bernardes LADS. Transcriptome analysis of Aspergillus niger grown on sugarcane bagasse. Biotechnol Biofuels. 2011;4:40.

17. Miller GL. Use of dinitrosaiicyiic acid reagent for determination of reduc ing sugar. Anal Chem. 1959:31:426-8.

18. Schuster A, Bruno KS, Collett JR, Baker SE, Seiboth B, Kubicek CP, et al. A versatile toolkit for high throughput functional genomics with Trichoderma reesei. Biotechnol Biofuels. 2012:5:1.

19. Christianson TW, Sikorski RS, Dante M, Shero JH, Hieter P. Multifunctional yeast high-copy-number shuttle vectors. Gene. 1992;1 10:119-22.

20. Loprete D. The protein kinase C orthologue PkcA plays a role in cell wal integrity and polarized growth in Aspergillus nidulans The protein kinase C orthologue PkcA plays a role in cell wall integrity and polarized growth in Aspergillus nidulans. Fungal Genet Biol. 2007;44:554-62.
21. Colot HV, Park G, Turner GE, Ringelberg C, Crew CM, Litvinkova L, et al. A high-throughput gene knockout procedure for Neurospora reveals functions for multiple transcription factors. PNAS. 2006;103:10352-7.

22. Construction H, Deletion G, Collopy PD, Colot HV, Park G, Ringelberg $\mathrm{C}$, et al. High-throughput construction of gene deletion cassettes for generation of Neurospora crassa knockout strains. Methods Mol Biol. 2010;638:33-40.

23. Gietz RD, Schiestl RH. High-efficiency yeast transformation using the LiAC/SS carrier DNA/PEG method. Nat Protoc. 2008:2:31-5.

24. Gietz RD, Schiestl RH. Applications of high efficiency lithium acetate transformation of intact yeast cells using single-stranded nucleic acids as carrier. Yeast. 1991;7:253-63.

25. Goldman GH, Marques R, Luciano A, Bernardes DS, Quiapin C, Vitorelli PM et al. Expressed sequence tag analysis of the human pathogen Paracoccidioides brasiliensis yeast phase: identification of putative homologues of Candida albicans virulence and pathogenicity genes. Eukaryot Cell. 2003;2:34-48.

26. Sambrook J, Russell DW. Preparation of cDNA libraries and gene identification. In: Sambrook J, David W, editors. Molecular cloning a laboratory manual. Cold Spring Harbor: Cold Spring Harbor Laboratory Press; 2001 , p. $10-1$

27. Cardoza RE, Malmierca MG, Hermosa MR, Alexander NJ, Mccormick SP, Proctor RH, et al. Identification of loci and functional characterization of Trichothecene biosynthesis genes in filamentous fungi of the genus Trichoderma. Appl Environ Microbiol. 2011;77:4867-77.

28. Vizcas JA, Gonza F, Elena R, Llobell A, Monte E, Gutie S. Partial silencing of a hydroxy-methylglutaryl-CoA reductase-encoding gene in Trichoderma horzianum CECT 2413 results in a lower level of resistance to lovastatin and lower antifungal activity. Fungal Genet Biol. 2007:44:269-83.

29. Huang Z, Chen X, Qin L, Wu H, Su X. A novel major facilitator transporter TrSTR1 is essential for pentose utilization and involved in xylanase induction in Trichoderma reesei. Biochem Biophys Res Commun. 2015:3045:663-9.

30. Verbeke J, Coutinho P, Mathis H, Quenot A, Record E, Asther M, et al. Transcriptional profiling of cellulase and expansin-related genes in a hypercellulolytic Trichoderma reesei. Biotechnol Lett. 2009;31:1399-405.

31. Livak KJ, Schmittgen TD. Analysis of relative gene expression data using real-time quantitative $P C R$ and the $2-\triangle \triangle C T$ method. Methods. 2001:25:402-8.

32. Galazka JM, Tian C, Beeson WT, Martinez B, Glass NL, Cate JHD. Cellodextrin transport in yeast for improved biofuel production. Science. 2010:330:84-6.

33. Schiestl RH, Gietz RD. High efficiency transformation of intact yeast cells using single stranded nucleic acids as a carrier. Curr Genet. 1989:16:339-46.

34. Yang J, et al. The I-TASSER Suite: protein structure and function prediction. Nat Methods. 2014:12:7-8

35. Zhang Y. I-TASSER server for protein 3D structure prediction. BMC Bioinform. 2008:9:40

36. Yang JM, Chen CC. GEMDOCK: a Generic Evolutionary Method for Molecular Docking. Proteins Struct Funct Genet. 2004;55:288-304

37. Yang JM, Frank Hsu D. Consensus scoring criteria in structure-based virtual screening. Emerg Inf Technol Conf. 2005;2005:165-7.

38. Yang JM. Development and evaluation of a generic evolutionary method for protein-ligand docking. J Comput Chem. 2004;25:843-57.

39. Deng D, Sun $P$, Yan C, Ke M, Jiang X, Xiong L, et al. Molecular basis of ligand recognition and transport by glucose transporters. Nature 2015:526:391-6.

40. Znameroski EA, Glass NL. Using a model filamentous fungus to unrave mechanisms of lignocellulose deconstruction. Biotechnol Biofuels. 2013;6:6.

41. Dos Reis TF, Menino JF, Bom VLP, Brown NA, Colabardini AC, Savoldi M, et al. Identification of glucose transporters in Aspergillus nidulans. PLoS ONE. 2013:8:11.

42. Sloothaak J, Odoni DI, Martins dos Santos VAP, Schaap PJ, Tamayo-Ramos JA. Identification of a novel L-rhamnose uptake transporter in the filamentous fungus Aspergillus niger. PLoS Genet. 2016;12:12

43. Polidori E, Ceccaroli P, Saltarelli R, Guescini M, Menotta M, Agostini D, et al Hexose uptake in the plant symbiotic ascomycete Tuber borchii Vittadini: biochemical features and expression pattern of the transporter TBHXT1. Fungal Genet Biol. 2007;44(3):187-98 
Capítulo I

44. dos Reis TF, de Lima PBA, Parachin NS, Mingossi FB, de Castro Oliveira JV, Ries LNA, et al. Identification and characterization of putative xylose and cellobiose transporters in Aspergillus nidulans. Biotechnol Biofuels. 2016:9:204

45. Quistgaard EM, Löw C, Guettou F, Nordlund P. Understanding transport by the major facilitator superfamily (MFS): structures pave the way. Nat Rev Mol Cell Biol. 2016;17:123-32.

46. Zhang W, Cao Y, Gong J, Bao X, Chen G, Liu W. Identification of residues important for substrate uptake in a glucose transporter from the filamentous fungus Trichoderma reesei. Sci Rep. 2015:5:13829.

47. Diallinas G. Understanding transporter specificity and the discrete appearance of channel-like gating domains in transporters. Front Pharmacol. 2014:5:207.

48. Farwick A, Bruder S, Schadeweg V, Oreb M, Boles E. Engineering of yeast hexose transporters to transport D-xylose without inhibition by D-glucose. Proc Natl Acad Sci. 2014;111:5159-64.

49. Sloothaak J. Chapter 7: general discussion. In: the uptake of carbon sources by Aspergillus niger. 2017. http://library.wur.n/WebQuery/wurpu bs/fulltext/414746. Accessed 27 Sept 2017.

50. Tian C, Beeson WT, lavarone AT, Sun J, Marletta MA, Cate JHD, et al Systems analysis of plant cell wall degradation by the model filamentous fungus Neurospora crassa. Proc Natl Acad Sci. 2009;106:22157-62.
51. Pribowo A, Arantes V, Saddler JN. The adsorption and enzyme activity profiles of specific Trichoderma reesei cellulase/xylanase components when hydrolyzing steam pretreated corn stover. Enzyme Microb Technol. 2012;50:195-203.

52. Sloothaak J, Odoni DI, de Graaff LH, Dos Santos VM, Schaap PJ, Tamayo Ramos JA. Aspergillus niger membrane-associated proteome analysis for the identification of glucose transporters. Biotechnol Biofuels. 2015;8(1):150

53. Gibson $\perp$. The hierarchical structure and mechanics of plant materials.J $\mathrm{R}$ Soc Interface. 2015;9:2749-66

54. Scheller HV, Ulvskov P. Hemicelluloses. Annu Rev Plant Biol. 2010;61:263-89.

55. Dos Santos Castro L, Pedersoli WR, Antoniêto ACC, Steindorff AS, SilvaRocha R, Martinez-Rossi NM, et al. Comparative metabolism of cellulose, sophorose and glucose in Trichoderma reesei using high-throughput genomic and proteomic analyses. Biotechnol Biofuels. 2014:7:41.

Submit your next manuscript to BioMed Central and we will help you at every step:

- We accept pre-submission inquiries

- Our selector tool helps you to find the most relevant journal

- We provide round the clock customer support

- Convenient online submission

- Thorough peer review

- Inclusion in PubMed and all major indexing services

- Maximum visibility for your research

Submit your manuscript at

www.biomedcentral.com/submit

( ) Biomed Central 


\section{Considerações sobre o capítulo I}

No capítulo I, descrevemos a caracterização do transportador de açúcar Tr69957, previamente identificado por nosso grupo de pesquisa por análises in silico de dados de RNAseq. A validação funcional do transportador foi realizada por meio de deleção gênica em $T$. reesei e complementação genômica em uma linhagem de S. cerevisiae EBY.VW4000 que não apresenta um sistema de transporte funcional.

Os dados descreveram, pela primeira vez em fungos filamentosos, a atuação de um transportador no carreamento de manose. Além disso, Tr69957 está também envolvido tanto no transporte de xilose quanto celobiose.

O transportador demonstrou ser capaz de carrear açúcares que estão naturalmente presentes durante o processo de degradação do bagaço de cana-de-açúcar, provenientes das porções celulósica e hemicelulósica da biomassa. Em adição, a deleção desse transportador afetou a expressão gênica de celulases e xilanases avaliadas durante o cultivo das linhagens parental e mutante em presença celobiose e bagaço de cana.

Os dados obtidos no capítulo I sugerem que Tr69957 exerce uma importante função no transporte de açúcares durante a degradação de bagaço de cana. Esses açúcares, quando carreados para o interior celular, atuarão na rede regulatória da expressão de genes que codificam para celulases e xilanases, influenciando todo o processo de degradação da biomassa. 


\subsection{Capítulo II}

Diz respeito a artigo publicado com as especificações que se seguem.

Título: New Genomic Approaches to Enhance Biomass Degradation by the Industrial Fungus Trichoderma reesei

Autores: Renato Graciano de Paula, Amanda Cristina Campos Antoniêto, Liliane Fraga Costa Ribeiro, Cláudia Batista Carraro, Karoline Maria Vieira Nogueira, Douglas Christian Borges Lopes, Alinne Costa Silva, Mariana Taíse Zerbini, Wellington Ramos Pedersoli, Mariana do Nascimento Costa, and Roberto Nascimento Silva.

Periódico: International Journal of Genomics. Volume 2018, Article ID 1974151, 17 pages

DOI: https://doi.org/10.1155/2018/1974151 


\section{Capítulo II}

\section{Considerações iniciais}

Esse capítulo apresentará um artigo de revisão contendo resultados de pesquisas proveniente do nosso grupo: Laboratório de Biotecnologia Molecular. No tópico "Involvement of Transporters during the Lignocellulosic Biomass Degradation Process in Trichoderma reesei", encontram-se todos os dados os quais retratam o envolvimento de transportadores de açúcar na degradação da biomassa lignocelulósica. 
Review Article

\title{
New Genomic Approaches to Enhance Biomass Degradation by the Industrial Fungus Trichoderma reesei
}

\author{
Renato Graciano de Paula ${ }^{\circ}$, Amanda Cristina Campos Antoniêto, \\ Liliane Fraga Costa Ribeiro, Cláudia Batista Carraro, Karoline Maria Vieira Nogueira, \\ Douglas Christian Borges Lopes $(\mathbb{D}$, Alinne Costa Silva, Mariana Taíse Zerbini, \\ Wellington Ramos Pedersoli, Mariana do Nascimento Costa, and Roberto Nascimento Silva
}

Molecular Biotechnology Laboratory, Department of Biochemistry and Immunology, Ribeirao Preto Medical School (FMRP), University of Sao Paulo, Ribeirao Preto, SP, Brazil

Correspondence should be addressed to Renato Graciano de Paula; renatogpaula@usp.br

Received 21 March 2018; Revised 20 June 2018; Accepted 29 July 2018; Published 24 September 2018

Academic Editor: Raul A. Platero

Copyright (c) 2018 Renato Graciano de Paula et al. This is an open access article distributed under the Creative Commons Attribution License, which permits unrestricted use, distribution, and reproduction in any medium, provided the original work is properly cited.

The filamentous fungi Trichoderma reesei is one of the most well-studied cellulolytic microorganisms. It is the most important fungus for the industrial production of enzymes to biomass deconstruction being widely used in the biotechnology industry, mainly in the production of biofuels. Here, we performed an analytic review of the holocellulolytic system presented by $T$. reese as well as the transcriptional and signaling mechanisms involved with holocellulase expression in this fungus. We also discuss new perspectives about control of secretion and cellulase expression based on RNA-seq and functional characterization data of T. reesei growth in different carbon sources, which comprise glucose, cellulose, sophorose, and sugarcane bagasse.

\section{Trichoderma reesei: Environmental and Lignocellulosic Biomass Degrader}

Trichoderma species are ubiquitous and cosmopolitan. They are very efficient colonizers of a variety of habitats and can be found from the tundra to the tropics [1], especially in lignocellulosic material and plant rhizospheres, and this effectiveness is translated by the ability of competently degrading the available substrate and of secreting different enzymes and metabolites used in the process [2-5]. The capability of growing in such a variety of carbon sources is also due to the high and fast capacity of responding to diverse environmental signals, being able to adapt according to that current background and regulate its growth, conidiation, and the production of enzymes and secondary metabolites. These signals may vary from different nutrients found in the milieu to the absence and presence of light, and adjusting to them is crucial for the survival of the microorganism $[2,4,6-8]$.
As a result of this versatility, Trichoderma species are very useful in many aspects that range from plant biocontrol [9] to various sorts of industries [10-13], especially for the cellulolytic enzymes produced by them. Among all species from this genus and which are industrially used, Trichoderma reesei is the most studied one regarding lignocellulosic biomass degradation, since it is the main producer of cellulolytic and xylanolytic enzymes [14-17]. The ability of growing in a wide range of carbon sources allows great variability in the production of cellulases, since the gene expression and secretion of enzymes are directly dependent on the different chemical signals produced from the diverse substrates. Considering that the plant biomass, one of the most important and complex substrates used by Trichoderma, is composed of mono-, di-, and polysaccharides, the different sugars may have different levels of induction or repression of cellulase genes. Some of the cellulase inducers are cellulose, $\beta$-glucan, xylan, lactose, cellobiose, and sophorose, while glucose is the main repressor carbon source [18]. When T. reesei degrades 
Capítulo II

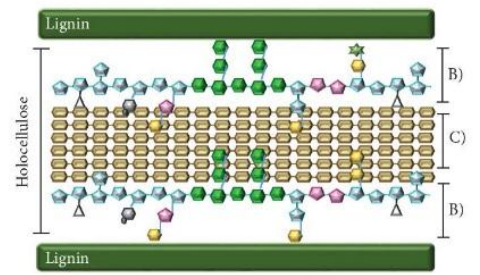

(a)

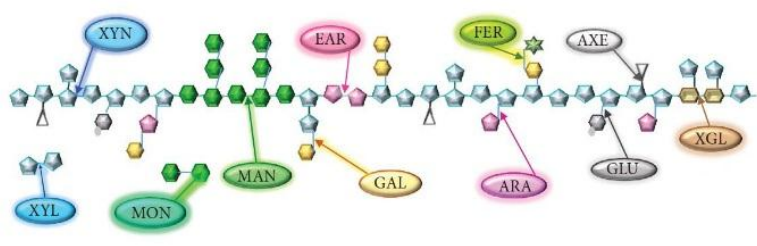

(b) Hemicellulose
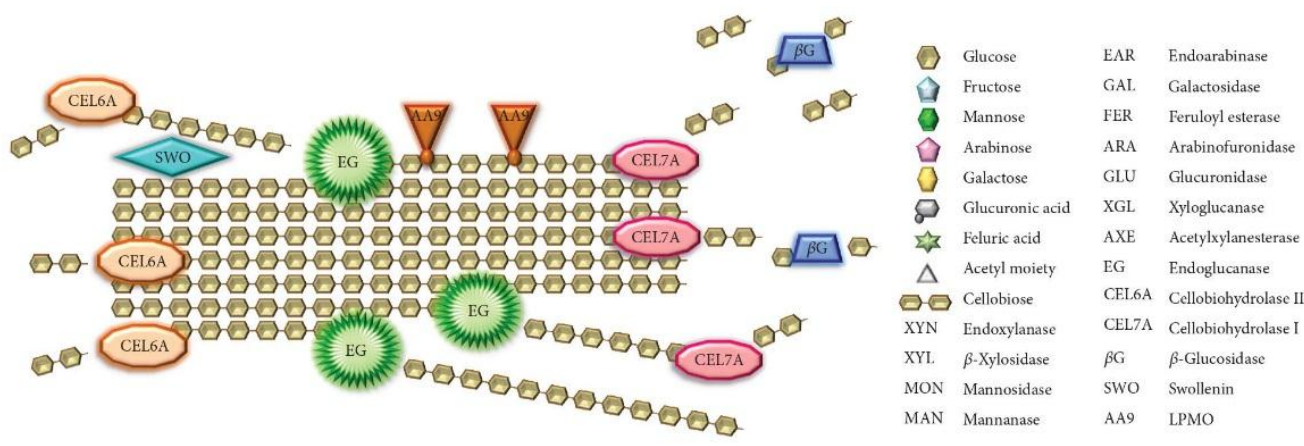

(c) Cellulose

FIGURE 1: Global regulation of holocellulase expression in T. reesei. (a) The schematic structure of the lignocellulosic biomass, which is constituted by lignin and holocellulose, composed of hemicellulose and cellulose. All chains are drawn from the reducing (left) to the nonreducing end (right). (b) Enzymes that attack hemicellulose act in synergy in order to efficiently hydrolyze it and promote a more accessible surface area on cellulose, to enhance cellulase activities. (c) The enzymatic degradation of cellulose: EG acts by cleaving in amorphous regions of the chain, while CEL6A and CEL7A cleave at the nonreducing and reducing ends, respectively. The resulting oligosaccharides from this cleavage are then broken into monosaccharides by $\beta$-glucosidase, so they become capable of being directly metabolized by the organism. SWO expands the cellulolytic chain to improve cellulase accessibility to it, and AA9 works through bivalentmetallic-ion-dependent oxidative metabolism (based, among others, on [39, 144-146]).

the lignocellulosic biomass, cellobiose may be converted into sophorose by a transglycosylation activity of a $\beta$-glucosidase $[19,20]$. The comparison of the genomes of Trichoderma species, including T. reesei, suggests they have a mycoparasitic common ancestral, probably from fungi that degrade lignocellulosic material. Considering this, T. reesei may have maintained the mycoparasitic characteristic, which allows it to have advantages over other species when competing for substrate, through the conversion of cellobiose into sophorose by transglycosylation to be metabolized $[21,22]$. Differently from other fungi, in T. reesei, sophorose acts as a very potent cellulase inducer in very low concentrations, being able to induce the expression of some xylanases as well $[23,24]$.

With the increasing concern about the environmental disadvantages that fossil fuels and nuclear energy represent nowadays, there has been considerable pursuit for new ways of generating large-scale renewable green energy. One of the currently most promising possibilities is the usage of lignocellulosic material from agricultural and industrial waste $[25,26]$. This material is mainly composed of cellulose and hemicellulose, which suffer enzymatic hydrolysis and are converted into simple carbohydrate monomers and finally into second-generation bioethanol $[13,27,28]$. However, considering that the plant biomass is highly recalcitrant, large amounts of enzymes are needed during the hydrolysis process, which make the biofuel production economically unfeasible [29-31]. In this context, Trichoderma reesei may play an important role in decreasing costs for bioethanol production, whereas it is the filamentous fungus with the greatest capacity of degrading the lignocellulosic biomass $[2,15,32]$.

\section{The Global Analysis of the Enzymatic Repertoire of Trichoderma reesei}

The filamentous fungus $T$. reesei obtains energy through the degradation of the lignocellulosic biomass, composed specially of the cellulose polymer $[2,33,34]$. The cellulolytic enzymes synergistically act to degrade the cellulose polymer Regarding the site of action, these enzymes are classified in at least three large groups: the endoglucanases, which cleave the internal bonds of the cellulose fiber; the exoglucanases, which act in the external region of the cellulose chain; and $\beta$-glucosidases, which hydrolyze soluble oligosaccharides into glucose molecules [2,35] (Figure 1). Recently, LPMOs (lytic 
polysaccharide monooxygenases) have been suggested to make the cellulose polymer more accessible to the action of traditional cellulases through an oxidative mechanism [36]. In addition to the LPMOs, a protein known as swollenin also participates in the deconstruction of the plant cell wall by breaking the hydrogen bonds between the cellulose microfibrils without hydrolyzing them, thus increasing the biomass degradation efficiency [37] (Figure 1).

In 2012, Häkkinen and coworkers performed a reannotation of all genes encoding enzymes belonging to CAZy (Carbohydrate-Active Enzymes-http://www.cazy.org) in T. reesei and identified 201 genes of glycosyl hydrolases, 22 carbohydrate esterases, and 5 genes of polysaccharide lyases [38]. The cellulases produced by $T$. reesei belong to six GH families: endo- $\beta-1,4-\mathrm{D}$-glucanases are found in the GH5, GH7, GH12, and GH45 families, the exoglucanases in the GH6 and GH7 families, and the $\beta$-glucosidases in the family GH3 [39]. The Cel7a is the dominant enzyme of the cellulolytic complex, comprising about $60 \%$ of the total proteins secreted by $T$. reesei, followed by Cel6a (20\%), and then the endoglucanases, mostly Cel7b (10\%). In fewer amounts, the $\beta$-glucosidases represent only $1 \%$ of the total proteins secreted by this species [40-42].

In 2014, dos Santos Castro and coworkers showed that when T. reese is grown in cellulase inducing carbon sources, such as cellulose and sophorose, CAZyme-encoding genes are highly transcriptionally induced. An opposite profile is observed during growth in glucose, in which most of the genes encoding GH families had low expression. In this study, 61 genes encoding CAZymes were highly expressed in the presence of cellulose in comparison to glucose [21]. Among these, the main gene upregulated was a copperdependent polysaccharide monooxygenase cel61b (ID 120961), almost 3 thousand-fold more expressed in cellulose than in glucose. The endoglucanase cel12a (ID 123232) was the second most upregulated gene in this condition, followed by a $\beta$-mannanase. In sophorose, 58 genes were transcriptionally induced when compared to glucose. The most expressed gene in this condition was the endoglucanase cel12a (ID 123232, as well as observed in cellulose). The two cellobiohydrolases of $T$, reesei cel7a (ID 123989) and cel6a (ID 72567) ranked the second and third among the most expressed genes in sophorose [21] (Figure 2). In a study by de Paula [43], 98 CAZyme-encoding genes were upregulated during growth in sugarcane bagasse compared to glycerol in the T. reesei QM6a strain. The endoglucanase cell $2 a$ was the third most expressed gene in this condition, similar to that found by dos Santos Castro and coworkers [21] in the presence of cellulose. The two CAZyme genes most expressed in sugarcane bagasse encode a mannanase from the GH76 family (ID 122495) and the hemicellulase xyn3 (ID 120229). Similar to that found by dos Santos Castro and coworkers in sophorose [21], the cellobiohydrolase cel7a was also highly expressed in sugarcane bagasse, achieving 326-fold higher expression in sugarcane bagasse than in glycerol (ID 122495) (Figure 2).

CAZyme gene expression is regulated at the transcriptional level by transcription factors such as XYR1 and CRE1 (for more details, see Transcriptional Regulation of

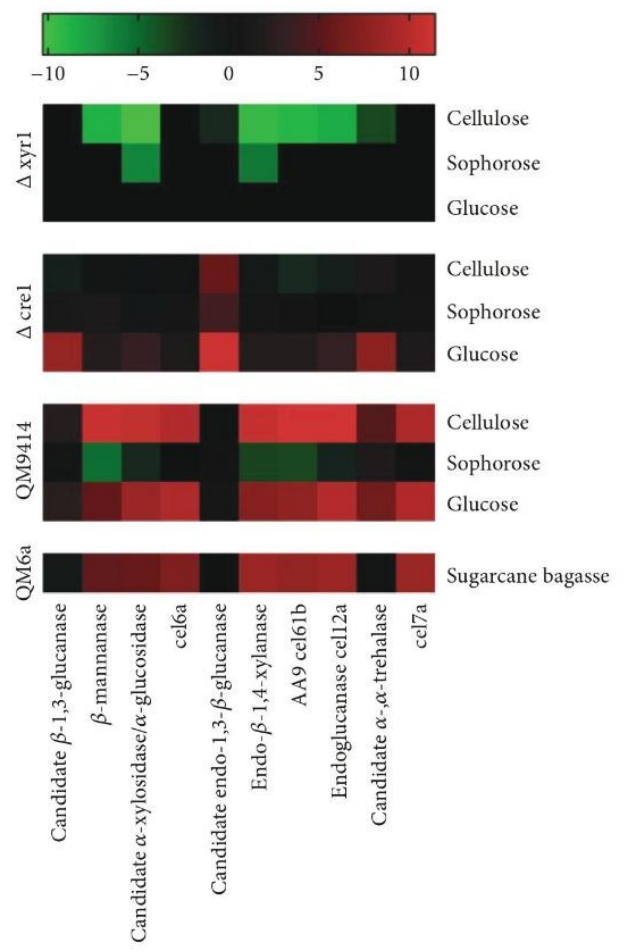

FIgURE 2: Heatmap expression of Top CAZy-encoding genes differentially expressed in $T$. reesei strains grown in cellulose, sophorose, glucose, and sugarcane bagasse. The results of gene expressions were transformed in Log2FoldChange values and employed to heat map construction using the GraphPad Prism version 7 program (https://www.graphpad.com/).

Biomass Degradation). In 2016, dos Santos Castro and coworkers showed that the XYR1 regulator positively regulates expression of at least 61 CAZyme genes in cellulose and 46 genes in sophorose [35]. The genes encoding a candidate $\alpha$-xylosidase/ $\alpha$-glucosidase (ID 69944), endo- $\beta$ 1,4-xylanase (ID 120229), and a copper-dependent monooxygenase polysaccharide candidate AA9 (ID 120961) were the major XYR1 target in the presence of cellulose. All of them were more than 500 -fold less expressed in the $\Delta x y r 1$ mutant compared to the parental QM9414, and the first two genes were also modulated by XYR1 in the presence of sophorose. However, none of these genes are under CRE1-mediated carbon catabolic repression (CCR) [44, 45] (Figure 2). CRE1-mediated CCR was also evaluated regarding the CAZymes of T. reesei by Antoniêto and coworkers [44, 45]. In these studies, the most evident CCR occurred during growth of $T$. reesei in glucose [45]. In this condition, several genes encoding CAZymes were repressed by CRE1. A gene encoding a candidate endo-1,3- $\beta$-glucanase (ID 73256) was the most repressed by CRE1, being more than 2 thousandfold more expressed in the mutant $\Delta$ crel compared to the QM9414, followed by another candidate $\beta$-1,3-glucanase 
(ID 56418) and a candidate $\alpha, \alpha$-trehalase (ID 123456) (Figure 2). The trehalase gene was also under positive regulation of XYR1 [35]. Modulation of the trehalase gene by the XYR1 and CRE1 regulators may be a strategy adopted by $T$. reesei to avoid the unnecessary use of the energy stock when a readily available carbon source is in the culture medium, since this disaccharide acts as an energetic reserve in fungi [44]. Taken together, these results showed that, although the cellulase gene expression profile is similar during $T$. reesei growth in inducing carbon sources such as cellulose, sophorose, and sugarcane bagasse, the mechanisms employed by XYR1 and CRE1 to control the expression of specific genes are dependent on the carbon source available in the environment (Figure 2).

\section{Involvement of Transporters during the Lignocellulosic Biomass Degradation Process in Trichoderma reesei}

The process of lignocellulosic biomass utilization involves the capacity of $T$. reesei to sense the insoluble cellulose in the environment and initiates the rapid production of the enzymatic machinery required to breakdown cellulose and offer the nutrients to its growth [46-48]. Appropriated sense of the extracellular insoluble cellulose is key to initiating the rapid synthesis of cellulases by this fungus, and the uptake of soluble sugars released from biomass hydrolysis denote a potential point of control in the induced cascade [48]. In this context, transporter proteins have an important role during the biomass degradation process. Transport systems act in the sensing and uptaking of essential nutrients and ions, allowing excretion of end products of metabolism and toxic substances. Also, these transporters are involved in communication between cells and the environment $[49,50]$. It is possible that organisms sense cellulose through recognition of sugars by a transporter in the membrane. In fact, two MFS sugar transporters, Stp1 and Crt1, were implicated in cellulose sensing and cellulase induction in T. reesei [48]. Transporter proteins can carry different small molecule inducers from the extracellular environment into the fungus influencing the expression of CAZyme-encoding genes [51-53]. Approximately, 5\% (459 genes) of the T. reesei genome comprises genes that encode proteins involved in transport [21]. Among these, the largest group of identified transporters belongs to the major facilitator superfamily (MFS), class of sugar transporters, followed by ABC (ATP binding cassette) transporters. These two families of transporter proteins have been most intensively studied among the fungal transporters $[34,54]$.

The genomes of the filamentous fungus encode large numbers of MFS transporters [55, 56]. These proteins can transport a broad variety of substrates and are divided into 17 distinct families among which three families (1, 5, and 7) are involved in sugar transport into the cell. These transporters carried out the transport of carbon sources, including hexose and pentose sugars, and small soluble molecules in response to ion gradients $[50,57,58]$. In the filamentous fungus, sugar transporters, which belong to the MFS permease family, have a characteristic to recognize and carry more than one type of sugar into the fungal cell. For example, the $T$. reesei STP1 transporter is involved in glucose and cellobiose uptake [48], as well as Aspergillus nidulans transporter XtrD was shown to be able to transport xylose, glucose, and several other monosaccharides [59].

Despite advances in studies about the involvement of MFS sugar transporters during biomass degradation, a very few sugar transporters have been functionally characterized in $T$. reesei $[48,60,61]$. A deep transcriptomic and proteomic study investigating the molecular basis for lignocellulosedegrading enzyme production in $T$. reesei during growth in cellulose, sophorose, and glucose revealed new components involved in cellulose degradation, including transporters, while the MFS permeases family was the most present in the different carbon sources evaluated [21]. In this study, MFS permeases differentially expressed in the three carbon sources were analyzed. The gene encoding MFS permease (ID 69957) and MFS permease (ID 76800), targets of light signaling in Trichoderma, were highly expressed in cellulose when compared to glucose and sophorose. In sophorose, a gene encoding MFS maltose permease (ID 48444) was highly induced by this carbon source, while the MFS permease ID 76641 was expressed at a higher level in glucose than in sophorose or cellulose [21]. Conversely, cultures with cellulose or sophorose promoted the expression of MFS permeases at similar expression levels, including crt1 (ID 3405), required for cellulase induction by cellulose and lactose, besides mediating the cellulose sensing process in $T$. reesei [48]; Hxt1, a glucose permease [60]; Str1 (ID 50894), a xylose transporter [61]; and MFS ID 79202, which is critical for cellulase production in lactose cultures, although it is related to a sucrose transporter. In addition, the stp1 exhibited a higher level of expression in sophorose than in cellulose, although it is involved in cellobiose and glucose transport [21].

In addition, in $T$. reesei, the global induction of genes in response to exposure to wheat straw showed that MFS transporters were highly transcribed in straw and repressed in glucose-rich conditions. The genes encoding MFS ID 3405 (crt1), ID 50894 (str1), and ID 69957 were upregulated in the presence of straw and downregulated in the presence of glucose [62]. Besides, during cultivation of T. reesei RUT C30 strain in sugarcane bagasse, the genes encoding the MFS permeases ctr1 and str1 were strongly induced by this carbon source at all the time points analyzed $(6,12$, and 24 hours) [63]. The induction of MFS transporters may be controlled by endogenous regulatory systems over a range of in vivo conditions. In $T$. reesei, the modulation of transporter expression was shown to be carbon sourcedependent [21, 35, 44]. A global transcriptome analysis of the $\Delta x y r 1 T$. reesei mutant strain and the parental strain QM9414 grown in the presence of cellulose, sophorose, and glucose as sole carbon sources showed that genes encoding to proteins belonging to MFS permease superfamily are the most modulated genes by XYR1 (Figure 3 ). The genes that encode a MFS permease ID 69957, ID 44175, ID 54632, ID 79202, ID 50894, and the ctrl showed to be strongly repressed by XYR1 in the presence of cellulose [35]. 
Capítulo II

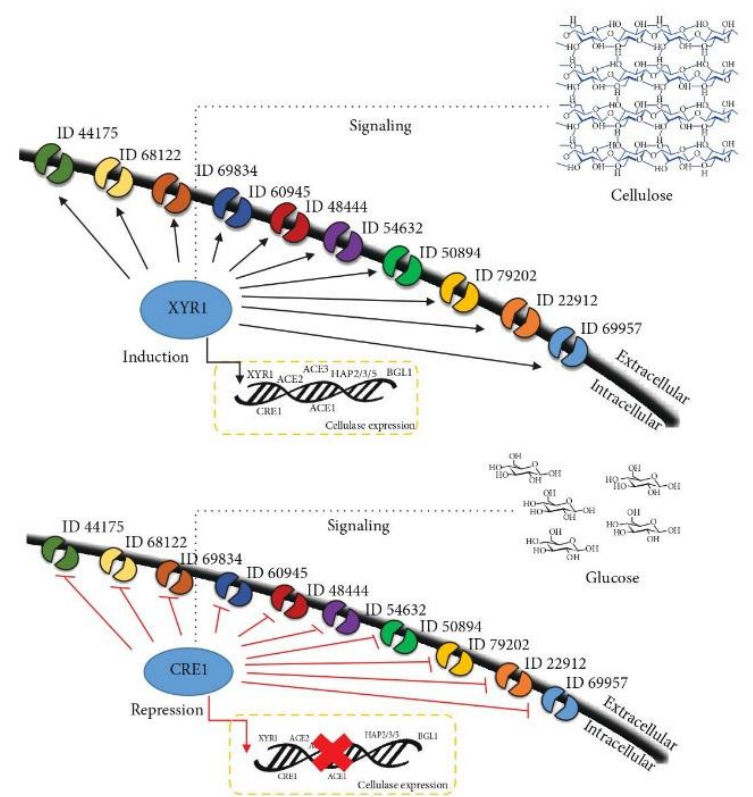

(a)

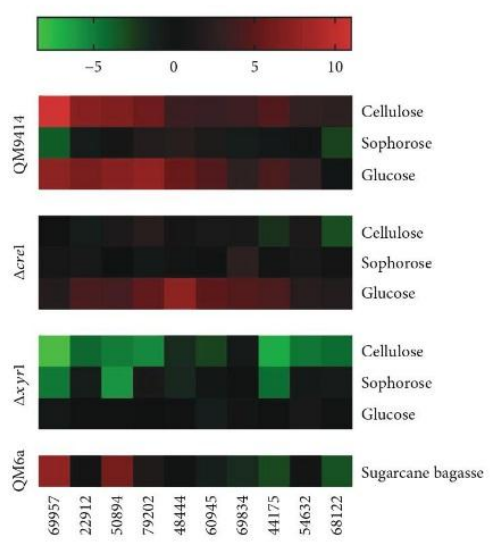

(b)

FIGURE 3: Sugar transporters potentially associated with the degradation of biomass in T. reesei. (a) The predicted model of XYR1 and CRE1mediated MFS permease regulation in T. reesei under cellulose inducing condition and glucose repressed condition. (b) Heatmap expression of Top MFS transporter-encoding genes differentially expressed in T. reesei strains grown in cellulose, sophorose, glucose, and sugarcane bagasse. The results of gene expressions were transformed in Log2FoldChange values and employed to heat map construction using the GraphPad Prism version 7 program (https://www.graphpad.com/).

Furthermore, it is possible that the protein transporters are involved in carbon catabolic repression (CCR) in T. reesei. During analysis between $\Delta c r e 1 T$. reesei mutant strain and parental strain QM9414, grown in cellulose, glucose, and sophorose, the main genes marked by CRE1-mediated CCR encode to proteins belonging to MFS permeases superfamily. Most genes of MFS permeases were upregulated by CRE1 in the presence of glucose. Among these, the expression of the maltose permease gene (ID 48444) and three other MFS permease genes (ID 60945, ID 79202, and ID 44174) was higher in the $\Delta$ cre 1 mutant than in the parental strain [45] (Figure 3). In sophorose, the gene encoding a xylose transporter gene (ID 104072) was highly repressed by CRE1. During the transcriptional analysis of $T$. reesei grown in wheat straw and glucose, this gene was strongly transcribed in wheat straw and repressed in glucose [62].

Furthermore, a large number of $\mathrm{ABC}$ transporters are encoded in T. reesei [34]. Generally, $\mathrm{ABC}$ proteins are integral to the membrane, acting as ATP-driven transporters for several substrates, including lipids, sugar, drugs, heavy metals, and auxin [64]. In fungi, $A B C$ transporters are involved with the secretion of secondary metabolites, resistance to toxic compounds, and cell signaling [63]. Although the $\mathrm{ABC}$ transporters have been shown to be important for different processes in fungi, the role of the transporters belonging to the $\mathrm{ABC}$ family is still unclear in $T$. reesei. In this fungus, the $\mathrm{ABC}$ transporters showed carbon source-dependent transcriptional regulation, which were upregulated in cellulose and sophorose [35]. In cellulose, the $\mathrm{ABC}$ transporter ID 76682 was highly upregulated, while the gene encoding the ABC transporter ID 80028 was upregulated in sophorose [21]. Additionally, in T. reesei, it was demonstrated that the transport of molecules by $\mathrm{ABC}$ transporters is highly induced by wheat straw and lactose than glucose $[53,65]$.

The ABC transporters showed to be modulated by transcription factors such as XYR1 and CRE1. In $\triangle x y r 1$ $T$. reesei mutant strain, the genes encoding $\mathrm{ABC}$ transporters ID 55814, ID 60116 (MRP-type ABC transporter), and ID 120114 were downregulated in the presence of cellulose, sophorose, and glucose, respectively. Oppositely, the gene encoding ABC transporter ID 58899 (MDR-type $\mathrm{ABC}$ transporter) was upregulated in the presence of cellulose [35]. In $\Delta$ cre 1 mutant strain, the gene encoding $\mathrm{ABC}$ transporter ID 76682 (PDR-type $\mathrm{ABC}$ transporter) was upregulated in the presence of cellulose [45] while in sophorose, the major CRE1 repressed gene was ID 76682. However, four other $\mathrm{ABC}$ transporter genes (ID 82105, 123293,73924 , and 58899) were repressed by CRE1 in the presence of this carbon source [44]. Among the identified $\mathrm{ABC}$ transporters, most of them are correlated with multidrug resistance (MDR), pleiotropic drug resistance (PDR), and multidrug resistance-related protein (MRP) $A B C$ protein subfamilies [66]. Although the ABC transporters 
contribute to multidrug resistance in microbial pathogens and tumor cells, in fungi, these transporters have been scarcely studied [34]. In other fungi, the ABC transporters are also related with mycoparasitic interaction and antifungal resistance $[67,68]$, and interestingly, several studies have shown the involvement of $\mathrm{ABC}$ transporters with the sugar transport [69]. For example, Sulfolobus solfataricus (extreme thermoacidophilic archaeon) uses several sugars as the sole carbon and energy source. This sugar transport is mediated by two families of protein binding dependent $A B C$ transporters that may transport different sugars such as arabinose, cellobiose, maltose, and trehalose [70]. In Clorynebacterium glutamicum, Watanabe et al. [71] described a functional characterization of a xyloside $A B C$ transporter and an enhanced uptake of xylooligosaccharides in the presence of a functional xylEFG-encoded xyloside $\mathrm{ABC}$ transporter. In Pyrococcus furiosus, cellobiose uptake involves an inducible $\mathrm{ABC}$ transporter system that not only binds cellobiose but also binds cellotriose, cellotetraose, cellopentaose, laminaribiose, laminaritriose, and sophorose [72].

As exposed here, both MFS transporters and $A B C$ transporters are suggested to be involved during the process of biomass degradation in $T$. reesei. The novel transporters identified offer new perspectives for studies about the involvement of protein transporters in the expression and secretion of cellulase for degradation of lignocellulosic biomass. With this, new proteins might be revealed as involved in the process to sense and transduce signals related to biomass deconstruction, providing future strain improvement for cellulase production. The characterization of these transporters may allow the construction of more efficient strains in the degradation of plant biomass and contribute to the implementation of $T$. reese $i$ in the bioethanol industry.

\section{Transcriptional Regulation of Biomass Degradation}

The regulation of holocellulose degradation by the fungus T. reesei is a highly coordinated phenomenon dependent on the carbon sources available in the medium. In the presence of readily metabolizable carbon sources, such as glucose, the fungus represses the genes accountable for the expression of cellulolytic enzymes as a way of saving energy, while in the presence of inductive carbon sources, such as cellobiose and sophorose, the fungus activates the cellulase production. At the transcriptional level, transcription factors are the key proteins for regulating the expression of genes that act on the hydrolysis of the cellulose polymer [32, 73-75]. In T. reesei, ten transcription factors involved in the regulation of this process have been identified so far. They are the positive regulators XYR1, ACEII, ACEIII, LAE1, VEL1, BglR, and the HAP2/3/5 complex, as well the repressors ACEI, RCE1, and CRE1 (Figure 4).

In $T$. reesei, the XYR1 is the master positive regulator of cellulase production, and deletion of this transcription factor totally eliminates the cellulase gene expression and also impairs the induction of hemicellulolytic genes involved with the degradation of xylans and arabinans [73, 76-78]. In 2016, dos Santos Castro and coworkers showed that XYR1 mainly regulates genes belonging to the CAZymes family, in a carbon source-dependent manner [35]. In this work, two xylosidases were the main downregulated genes in the $\Delta x y r 1$ mutant in the presence of cellulose (ID 69944; 1260 -fold) and sophorose (ID 121127; 209-fold). In addition to CAZymes, transcription factors and transporters were also regulated by XYR1. Besides XYR1, the deletion of the aceII transcription factor causes a decrease in the transcription levels of most cellulases and significantly reduces the cellulolytic activity when the fungus is grown in a cellulosecontaining medium [79]. Furthermore, the ACEIII transcription factor was more recently discovered, and its deletion was detrimental to the production of cellulases and xylanases in T. reesei [80]. It is believed that the HAP2/3/5 complex promotes the formation of an open chromatin structure, necessary for the activation of the transcription process [81]. In addition, the BglR transcription factor acts as a positive regulator of $\beta$-glycosidases-specific genes [82]. Deletion of the lae1 reduces the production of cellulases, xylanases, and the auxiliary factors CIP1 and swollenin [83]. Finally, deletion of vell completely decreases the expression of cellulases, xylanases, and xyrl genes in the presence of lactose. Interestingly, studies have shown that a combined action occurs between the LAE1/VEL1 complex for regulation of genes involved in biomass degradation $[83,84]$.

Among the negative regulators of cellulase gene transcription, the main transcription factor is the CRE1 catabolic repressor [75]. In 2014, Antoniêto et al. showed that, in addition to traditional cellulases, CRE1 deletion affects the expression of genes involved in nutrient transport, other transcription factors, and oxidative metabolism. In the presence of cellulose, this regulator represses genes encoding copper transporters and ferric reductase enzymes and, consequently, inhibits the access of the traditional cellulases to the cellulose polymer. In the presence of glucose, CRE1 acts suppressing the expression of genes related to the entry of the inducers into the cell [45]. It was also shown that the transcription factor xyr1 (ID 122208) is the main target regulator of CRE1 in the presence of glucose, being almost 40 times more expressed in the mutant $\Delta c r e 1$ when compared to the parental QM9414 [45]. In sophorose, CRE1 mainly modulates CAZYmes and membrane permeases, including maltose permeases that possibly act transporting the disaccharide sophorose [44]. Regarding the other negative regulators of cellulose degradation, studies have shown that ACEI represses the expression of the major cellulolytic genes (cbh1, cbh2, egl1, and egl2) and xylanases (xyn1 and xyn2), under the cellulose- and sophorose-inducing conditions [85]. In 2017, Cao and coworkers identified a new transcription factor, Rcel, which acts as a repressor of cellulase gene expression, antagonizing XYR1 by binding to the $c b h 1$ promoter [86].

Despite the numerous studies about the transcription factors already identified in $T$. reesei, several regulatory proteins involved in the regulation of the lignocellulosic biomass deconstruction have not been characterized yet (Figure 4). In a study of dos Santos Castro and coworkers [21], the expression of 7 genes encoding transcription factors was affected during growth in cellulose. Likewise, 18 genes 
Capítulo II

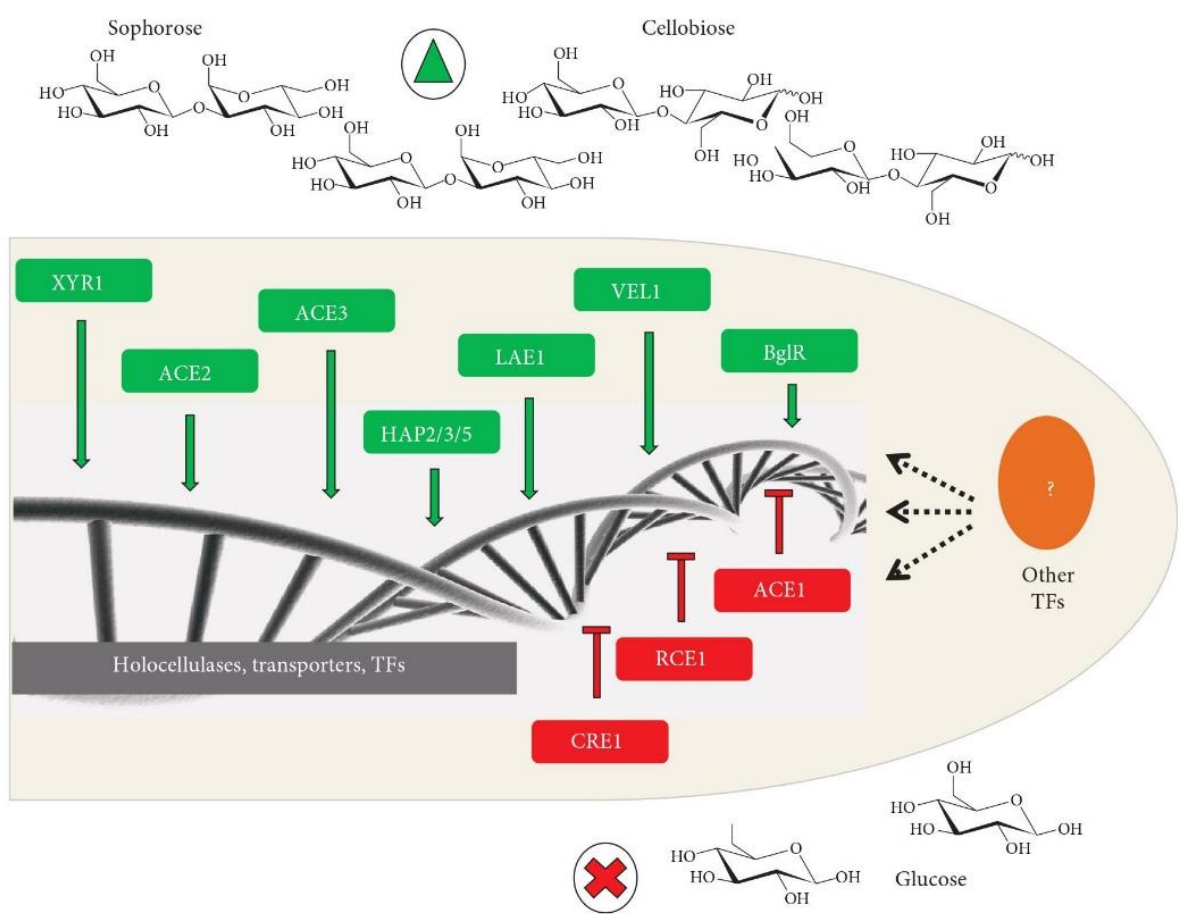

FIGURE 4: Overview of the transcriptional regulation of biomass degradation. The regulation of cellulose deconstruction involves at least 10 transcription factors: the positive regulators XYR1, ACEII, ACEIII, LAE1, VEL1, BglR, and the HAP2/3/5 complex, as well the repressors ACEI, RCE1, and CRE1. However, several transcription factors still not identified are potentially involved in this mechanism.

were also modulated in the presence of sophorose and glucose. In sugarcane bagasse, 88 transcription factors were modulated in the QM6a strain compared to the growth in glycerol [43]. Expression of several genes encoding transcription factors was also under regulation of XYR1 and CRE1. During cultivation in cellulose and glucose, 14 transcription factors were targeted by the CRE1-mediated mechanism of carbon catabolic repression (CCR) [45]. In sophorose, 8 regulators were also regulated by CRE1 [44]. The main positive regulator of cellulase production, XYR1, regulates the expression of other 31 transcription factors in the presence of cellulose, 17 in sophorose, and 7 in glucose [35]. In all these studies, most of the transcription factors modulated have not been characterized yet, which highlights the importance of exploring more about the regulatory proteins involved in the degradation of biomass.

\section{Epigenetic Regulation of \\ Holocellulase Expression}

Another important mechanism of gene transcriptional regulation involves the chromatin modification, a phenomenon that includes the modification of the histones which are the proteins responsible for the DNA packaging. In T. reesei, the evidence of nucleosome rearrangement in the promoter region of cel6a and cel7a suggests that chromatin remodeling is necessary to promote cellulolytic enzyme expression [81, 87]. Interestingly, deleting the methyltransferase LAE1 impairs cellulase expression, while overexpressing this protein increases cellulase expression and changes in the $\mathrm{H} 3 \mathrm{~K} 4$ methylation pattern in the promoter region of cel5b [83]. This mechanism of regulation was also demonstrated in $M$. oryzae, in which deleting the methyltransferase MoSET1 decreased cellulase induction [88]. Likewise, acetyltransferases are important enzymes involved with chromatin remodeling. In $T$. reesei, acetyltransferases belonging to the GCN5 family are crucial for cellulase expression [89]. During growth of the T. reesei QM6a in sugarcane bagasse, de Paula [43] showed that at least 9 genes related to chromatin remodeling were upregulated and 8 downregulated in comparison to glycerol. Of these genes, the acetyltransferase SidF (ID 82628) was almost 40 times more expressed in sugarcane bagasse, reaching the top of the list of genes modulated by this carbon source [43]. Also, dos Santos Castro and coworkers showed that two genes encoding a SWI-SNF chromatin-remodeling complex protein (ID 123327 and ID 122943) were also highly expressed in the presence of cellulose and sophorose [21]. This last gene was a target of CCR by CRE1 under cellulose condition [45]. All these findings reinforce the evidence of the involvement of the chromatin modifications in the mechanism of biomass degradation by the filamentous fungus $T$. reesei. 
The genetic engineering has become an important way for improving the production of holocellulolytic enzymes. The modification of gene promoters has also been extensively studied. Recently, Hirasawa and coworkers modified the promoter region of $x y n 3$ by using the $x y n 1$ cis-acting region and obtained improved enzyme expression [90]. A study of Zou and coworkers also showed that the CRE1 binding motifs in the promoter region of $c b h 1$ were replaced by the binding motifs of the positive regulators ACEII and the HAP2/3/5 complex, thus improving the promoter efficiency [91]. In addition, Uzbas and coworkers obtained a $\Delta x y r 1$ strain able to secrete the cellulases $c e l 7 a$, cell $b$, and cell $a$ under control of the promoter regions of two highly expressed genes tef 1 and $c d n a 1$ in a glucose-containing medium [92]. Similarly, the CCR in the presence of glucose was also eliminated by the deletion of CRE1 binding sites and insertion of multiple copies of positive regulator-binding sites in the promoter region of $c b h 1$, also increasing the heterologous gene expression in T. reesei [93]. These reports highlight the importance of investigating the transcription factors involved in the regulation of biomass degradation and the mechanisms through which these regulators interact with the architectural framework of the DNA in order to improve the holocellulase production.

\section{Signaling Pathways Involved in Cellulose, Sophorose, Glucose, and Sugarcane Bagasse Recognition}

The sensing of the changing environment is an important event for both survival and fungi competition. The fungi have appreciated mechanisms involved in sending signals and reacting to them $[34,94,95]$. Right after the perception of environmental signals, a complex network can be initiated, which is responsible for integrating all signals and promoting a suitable gene response to desirably react to the environment conditions [34]. In $T$. reesei, different signaling pathways have been described to be involved with fungal development and environment sensing. Among these, the signaling pathways dependent on G protein, cAMP, Ras-GTPases, protein kinases, phosphatases, calcium, and MAPK are the mostly characterized intracellular pathways although some aspects remain unclear [95-104]. Several studies showed the involvement of $\mathrm{G} \alpha$ proteins in the regulation of cellulase gene transcription by light $[105,106]$. A functional characterization of a GPCR-encoding gene of Trichoderma atrovoviride showed its role in vegetative growth and conidiation [107] and expression of chitinase-encoding genes [108]. Recently, it was demonstrated that two $G$ proteins $G \beta$ and $G \gamma$ s act along with a class I phosducin protein controlling the expression of glycoside hydrolase genes [109]. The cAMP pathway is a highly conserved signaling cascade in which cAMP acts as secondary messenger promoting the integration of different pathways [99]. In T. reesei, cAMP levels control cellulase gene expression [110] and according to Nogueira et al. [111], this regulation is in a carbon source-dependent manner.

The cellulase gene expression can also be regulated by the dynamics of protein phosphorylation and dephosphorylation involving protein kinases and phosphatases [34], respectively. Schuster et al. [112] demonstrated the role of protein kinase $\mathrm{A}$ (PKA) in the regulation of cellulase expression in the presence of light. Additionally, the deletion of a T. reese casein kinase II promotes the decrease of chitinase expression and repression of sporulation and glucose metabolism [113]. Similarly, $\mathrm{He}$ et al. [114] showed that the deletion of protein kinase EKil increases the chitinase-encoding gene expression, radial growth, conidiation, and ethanolamine accumulation in the cell wall. The MAPK-mediated phosphorylation can regulate important processes in $T$. reesei. The deletion of the MAPK gene $t m k 3$ induced a decrease in transcription and cellulase production [115]. Furthermore, it was also demonstrated that $t m k 2$ is involved in processes regulating cell wall integrity, sporulation and, cellulase production [116]. Recently, it was shown that MAPK IME2 represses the expression of the three main cellulase genes (cbh1, cbh2, and egl1) in T. reesei as well as activates the XYR1 and CRE1 expressions [117].

Finally, another interesting signaling cascade involved with the regulation of important processes in fungi is the intracellular calcium-dependent signaling pathway. The calcium homeostasis is essential for organisms, and its intracellular level reflects the environmental changes $[118,119]$. In $T$. reesei, calcium-modulated protein (calmodulin) has an important role in xylanase expression [120]. Equally, it was demonstrated that NCS (neuronal calcium sensor-like) interacts with calcineurin and phosphodiesterase, regulating the light-dependent signaling pathway involved with the control of cellulase expression [121]. Recent reports have shown the differential expression of genes encoding calcium transporters and other calcium signaling pathway members during cultivation of $T$. reesei QM9414, $\Delta x y r 1$ $\Delta c r e 1$ strains in the presence of cellulose, sophorose, and glucose $[21,35,44,45]$. Similarly, the cultivation of T. reese QM6a strain in sugarcane bagasse, glucose, and glycerol induced the expression of genes encoding $\mathrm{Ca}^{2+}$-ATPases and other calcium signaling transporters [43]. These results suggest the involvement of different signaling pathways controlling cellulase expression in the filamentous fungus $T$. reesei.

A deep analysis of gene expression in two functional mutant strains of main transcription factors (XYR1 and CRE1) $[35,44,45]$ and two MAPK-encoding genes showed that different signaling pathways and regulatory mechanisms are involved with the regulation of cellulase expression [43]. The main finding of these studies was that the enzyme regulation is carbon source-dependent. The growth of the QM9414 parental strain in the presence of cellulose and sophorose revealed a distinct expression pattern of genes encoding proteins involved with intracellular signaling. Additionally, 50 and 28 genes related to signal transduction were differentially expressed in the presence of cellulose and sophorose, respectively [35]. In cellulose, the main upregulated gene encoded to a conidiospore surface protein cmp1 (ID 72379), which was 21-fold more expressed in the parental strain. Oppositely, the most upregulated gene in sophorose encoded to an unknown protein (ID 73119), which was 8-fold more in the parental strain. Regarding 
Capítulo II

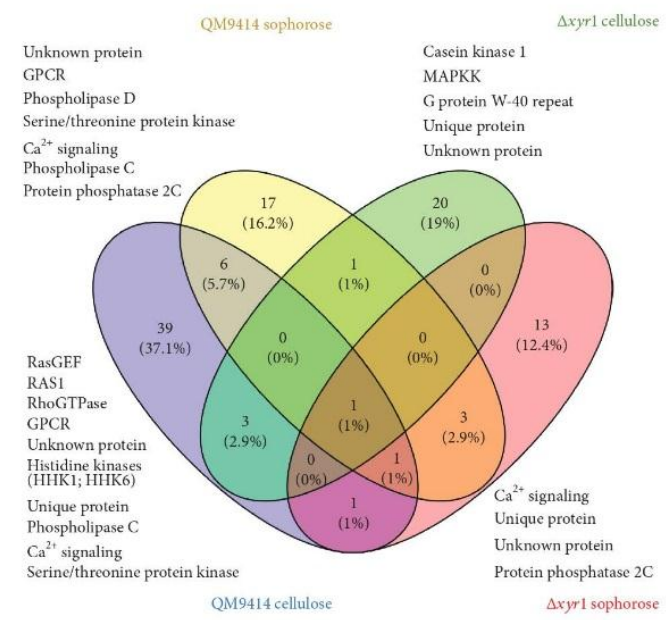

(a)

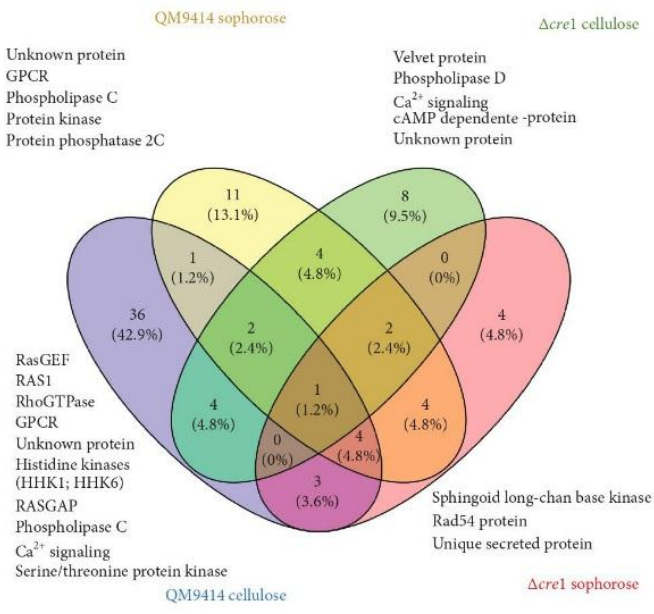

(b)

FIGURE 5: Expression pattern of differentially expressed signaling pathway genes in T. reesei during cultivation in cellulose and sophorose. (a) Comparative Venn diagram of expressed genes between the QM9414 and Axyr1 mutant strains in the presence of cellulose and sophorose. Venn diagram clustering was designed using Venny 2.1 tools. (b) Comparative Venn diagram of expressed genes between the QM9414 and $\Delta$ cre 1 mutant strains in the presence of cellulose and sophorose. Venn diagram clustering was designed using Venny 2.1.

downregulated genes, an unknown protein (ID 65522, $12-$ fold) was the most repressed in the presence of cellulose. Moreover, the most repressed gene in the presence of sophorose encoded the conidiospore surface protein $\mathrm{cmp} 1$ (ID 72379) being 69-fold less expressed in this condition [35]. Curiously, this gene was the most upregulated one when the QM9414 mutant strain was grown in the presence of cellulose. This result suggests that this protein may have an important role in cellulose recognition although the aspects about the regulatory mechanisms involved with the signal transduction remain unclear.

Here, we compared the expression patterns of signaling pathway-encoding genes in two functional mutant strains of the XYR1 positive and CRE1 negative regulators of cellulase expression in $T$. reesei. The reported studies have shown there is a specific pattern of signaling pathways for the recognition of different carbon sources (Figure 5). In the QM9414 parental strain, the RAS-GTPAses (RAS-EGF, RAS1, and RhoGTPase) and histidine kinases (HHK1 and HHK6) are the main activated proteins (Figure 5(a)). Moreover, ras1 gene (ID 67275) and hhk6 gene (ID 62751) were 8 -fold and 2-fold more expressed in the presence of cellulose, respectively [35]. Zhang et al. [97] showed that ras1 plays important roles in some cellular processes such as polarized apical growth, hyphal branch formation, sporulation, and cAMP level adjustment. Additionally, the deletion of GTPase ras 2 modulates the expression of major cellulase genes and transcription factors in cellulose. The growth and protein secretion of $T$. reesei in cellulose cultures were decreased in $\Delta r h o 3$ GTPase mutant strain, suggesting rho3 is involved with secretion processes in this fungus [100].
In the presence of sophorose, we observe distinct expression patterns, being GPCR, phospholipases D and C, and $\mathrm{Ca}^{2+}$ - signaling the main pathways involved with carbon source recognition (Figure 5(a)). The $\Delta x y r 1$ mutant strain demonstrated a distinct pattern of regulation, and, in the presence of cellulose, we observed the activation of casein kinase 1 and MAPKK signaling pathways (Figure 5(a)). The gene encoding to casein kinase 1 (ID 55049) was 2.5-fold more expressed in this condition, and the MAPKK (ID 57513) was increased about 2-fold in cellulose as the carbon source [35]. Wang et al. [113] showed that the casein kinase pathway governs chitinase expression, and beyond that, casein kinase-dependent phosphorylation has been suggested to be an important mechanism of regulation of DNA-binding zinc finger proteins, such as CRE1 [122]. These results suggest that XYR1 is a negative regulator of some genes encoding components of intracellular signaling pathways, such as MAPK and casein kinase cascades, involved with cellulose recognition being this regulation an additional mechanism of transcriptional regulation of cellulase expression.

The functional $\Delta c r e 1$ mutant strain exhibited a specific expression pattern related to signaling pathways. In the presence of cellulose, the main signaling pathways involved with cellulose sensing were $\mathrm{Ca}^{2+}$, phospholipase, cAMP, and velvet-dependent signaling pathways (Figure $5(\mathrm{~b})$ ). The $\mathrm{Ca}^{2+}$-dependent protein kinase (ID 62181, 5.7-fold) was the most upregulated gene in this condition. Moreover, a cAMP-dependent protein (ID 119614) was 2-fold more expressed in $\Delta c r e 1$ grown in cellulose [45]. The phospholipase D gene (ID 22331) was 3.8-fold more expressed in $\Delta c r e 1$ in the presence of cellulose [45]. Finally, the deletion of cre1 promoted a decrease of 2.3-fold in the expression 
Capítulo II

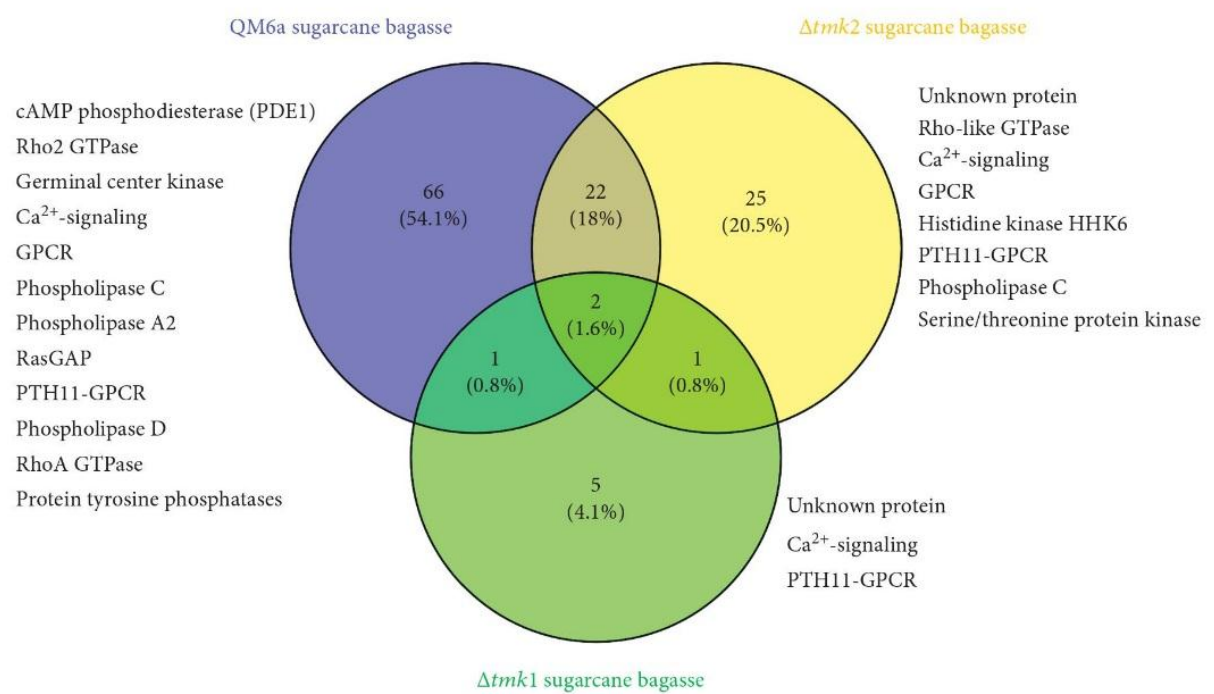

FIGURE 6: Expression pattern of differentially expressed signaling pathway genes in QM6a parental and two functional MAPK-mutant genes in the presence of sugarcane bagasse. (a) Comparative Venn diagram of expressed genes between the QM6a, $\Delta t m k 1$, and $\Delta t m k 2$ mutant strains in the presence of sugarcane bagasse. Venn diagram clustering was designed using Venny 2.1.

of regulatory protein velvet 1 (ID 122284). KarimiAghcheh et al. [84] showed the deletion of vel1 completely blocked the expression of xylanases, cellulases, and the regulator XYR1 in the presence of lactose. Since vel1 was downregulated with cre1 deletion, this result suggests that CRE1 might indirectly regulate the XYR1 expression in a vel1-dependent mechanism, and this may be an unclear mechanism of CCR regulation in $T$. reesei.

The growth of $T$. reesei QM6a in sugarcane bagasse demonstrated a specific expression profile of signalingencoding genes. In this condition, the expression of genes belonging to CAMP, GTPase, germinal center kinase, calcium, phospholipases, GPCR, protein phosphatases, and PTH11 signaling pathways was observed (Figure 6). Among these, PTH11-encoding genes were an overrepresented category, where eight genes were differentially expressed in this condition. The most upregulated PTH11 (ID 69500) was 14.5-fold more expressed in the presence of sugarcane bagasse [43]. In the filamentous fungus Neurospora crassa, PTH11 GPCR seems to be a yet-unclear key role in cellulose recognition and in the control of holocellulytic enzyme expression [123]. De Paula [43] showed in a global transcriptional analysis of two functional mutants for the MAPK signaling pathway that there is a cross talk among different signaling pathways in the presence of sugarcane bagasse. In the $\Delta t m k 2$ mutant strain, the main signaling pathways involved with the sugarcane recognition are Rho GTPase, GPCR, histidine kinase, and PTH11 GPCR (Figure 6). Interestingly, PTH11-encoding genes were also overrepresented in the $t m k 2$ deletion when compared to the parental strain [43]. The deletion of $t m k 1$ alters the expression of few genes belonging to signaling pathways. Only $4.1 \%$ of all genes related with intracellular signaling were involved with sugarcane bagasse recognition in $\Delta t m k 1$ mutant strain. Curiously, Vercoe et al. [124] demonstrated in Ruminococcus flavefaciens, a cellulolytic bacterium, that the phosphorylation and dephosphorylation dynamics are important for carbon source recognition and regulation of carbon metabolism. Together, our results suggest that in $T$. reesei, there may be a mechanism for carbon source recognition involving PTH11 GPCR, and that this process might be regulated by posttranslational events.

The understanding of how signal transduction pathways modulate cellulase gene expression has acquired attention, such as tools for strain improvement in T. reesei [125] The adequate environmental perception is a crucial step for regulation of gene expression. Thereby, changing transmission of signals aiming at the adjustment of enzyme secretion in response to environmental conditions is an advantageous alternative to enhance the activity efficiency of genes of interest [18]. Different approaches can be employed to improve the production of enzymes by $T$. reesei. One of them is the manipulation of the expression of holocellulolytic-encoding genes by increasing gene expression of activators and/or decreasing expression of repressors that control the expression of the cellulose- and hemicellulose-degrading enzymes. Thus, to carry out this task, a deeper knowledge of holocellulase regulation is crucial $[23,35,45,76,126-128]$.

In order to accomplish improvement in cellulase expression, different signal transduction mechanisms can be exploited. The holocellulytic gene expression may be regulated by different factors such as light, carbon and nitrogen sources, $\mathrm{pH}$, temperature, inorganic compounds, 
transcription factors, and epigenetic events $[21,35,44,45,81$, $87,126,129-133]$. These factors and their effects in regulating intracellular signaling pathways have been well studied in Trichoderma. As an example, in T. reesei, light and photoreceptors BLR1 and BLR2, which belong to light signaling, are known to regulate expression of cellulase genes [134, 135]. Regarding $c b h 1$ and $c b h 2$, the two main cellobiohydrolases, it has been demonstrated that growth of $T$. reesei in the presence of light promotes an increase of 2 -fold in gene expression in the presence of cellulose [134, 135]. The signal integration of light and nutrient signaling was an important discovery in the understanding of cellulase gene expression $[105,106]$. The G-protein alpha subunits GNA1 and GNA3 were described to be involved in light-dependent regulation of cellulase gene expression. Additionally, transcriptional analysis of the effect of deletion of GNB1 and GNG1 as well as the phosducin-like protein PHLP1 showed that glycosyl hydrolases are the major targets of light-dependent signaling by heterotrimeric G-proteins [109]. The intracellular level of cAMP directly affects cellulase expression [110, 136]. Nogueira et al. [111] showed that intracellular levels of cAMP were 4 -fold in the presence of sophorose, and cAMP may regulate secretion of cellulolytic enzymes in $T$. reesei in the presence of this sugar. Interestingly, de Paula [43] showed that deletion of MAPK gene tmkl promoted the downregulation of the main holocellulolytic genes of $T$. reesei. These results suggest that TMK1 is a positive regulator of cellulase gene expression and point this gene as a potential target for improvement engineering approaches to enhance cellulase expression in this fungus. Finally, all the knowledge about intracellular signaling pathways and its effects in the cellulase expression in T. reesei will provide important insights for metabolic engineering for strain improvement to be used in biotechnological industries.

\section{The New Players Potentially Involved in $T$, reesei Lignocellulosic Biomass Degradation}

In order to survive in different environments, filamentous fungi must be able to sense the surroundings and respond to it accordingly. Once the fungus senses the carbon source (whether it is sugarcane bagasse, cellulose, or sophorosecellulase inducers), a signaling cascade is activated, and it ends with increasing/decreasing the transcription level of certain genes involved in the degradation of each carbon source. However, all this sensing and responding processes are still not completely characterized. Attempts to solve this puzzle have been made by analyzing transcriptome results, and several studies have shown that $T$. reesei presents genes that code for proteins of unknown function [137].

A differential analysis of expressed genes when $T$. reesei was cultivated in cellulose versus glucose, in sophorose versus cellulose, and in sophorose versus glucose revealed that about 35 to $46 \%$ of the genes presented unknown function [21]. Also, when analyzing the top 10 upregulated genes in cellulose, five of them corresponded to protein of unknown function [21]. Among the top 10 upregulated genes in sophorose, there were three of unknown function. These results suggested these genes (were upregulated in inducing conditions) play an important and so far a neglected role in biomass degradation.

Some transporters have been reported to be involved with sensing external carbon sources and thus with the induction of CAZymes $[48,61]$. Although the importance of these proteins has been known, specially sugar transporters, for the cellular response to the environment, there are putative transporters that have been differentially expressed [21, 35, 44, 45] and have not yet been characterized. Figure 7 (a) summarizes a few genes that have been expressed in very different levels depending upon the carbon source. Among them, four copper transporters (ID 52315, ID 62716, ID 71029, and ID 108749) had transcriptional levels decreased in the presence of sophorose [21]. Supporting this result, Bak showed in 2015 that a copper transporter was downregulated in Phanerochaete chrysosporium cultivated in rice straw compared to no carbon source [138]. In 2016, dos Santos Castro showed that the deletion of $x y r 1$ caused the transcriptional levels of these genes to be upregulated in the knockout strain compared to the wild type in sophorose [35]. Deletion of the major transcription factor involved in CCR, cre1, did not result in changes in these four genes $[44,45]$. Therefore, these copper transporters may be involved in biomass degradation since copper is a cofactor required for LPMO activity [139], and the results obtained so far suggest they are regulated (directly or indirectly) by XYR1 but not by CRE1.

Another class of proteins related to biomass degradation regulation and that is still poorly characterized is transcription factor (TF). A lot of effort have been put into discovering new TF that would be important for the regulation of expression of genes that is important for an efficient biomass degradation [73, 80, 82, 140]. Antoniêto et al. [44, 45] and dos Santos Castro et al. [21,35] studied differential expression in T. reesei cultivated in different carbon sources. Also, they have studied two transcription factors, CRE1 and XYR1, and how they affect the transcriptional level of genes related to biomass degradation. Among the transcription factors that showed differences in expression, a few unknown TF presented particularly high differences of expression Figure 7(b). The high expression of these TFs in sugarcane bagasse, cellulose, and sophorose suggests that they can play a role on the regulation of biomass degradation and should be considered targets for further studies [137]. Particularly, gene 107641, classified as a transcription factor by KOG, was repressed in sugarcane bagasse and induced in sophorose. Also, the deletion of $x y r 1$ caused this gene (ID 107641) to be highly expressed when $T$. reesei was cultivated in sophorose, a cellulase inductor. Moreover, this TF (ID 107641) was also highly expressed in the knockout of cre 1 when cultivated in cellulose Figure $7(\mathrm{~b})$. All these results combined suggest that this TF (ID 107641) is involved in the regulation of transcription of enzymes related to biomass degradation and that XYR1 and CRE1 supposedly act as repressors for the expression of this TF. Several studies have identified genes encoding putative fungal C6 zinc fingertype transcription factors enriched among the differential 
Capítulo II

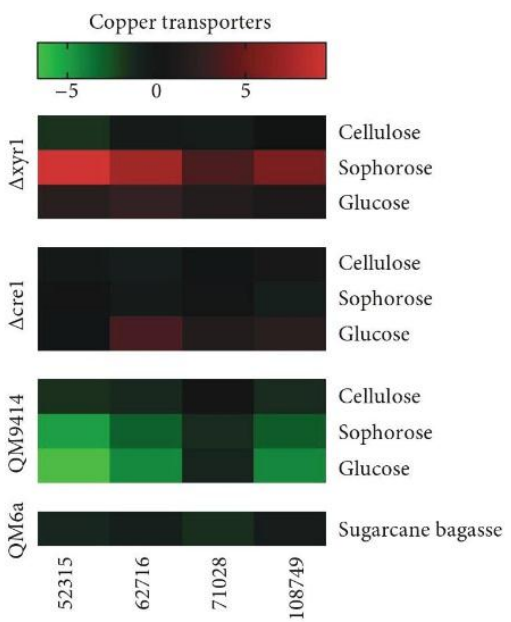

(a)

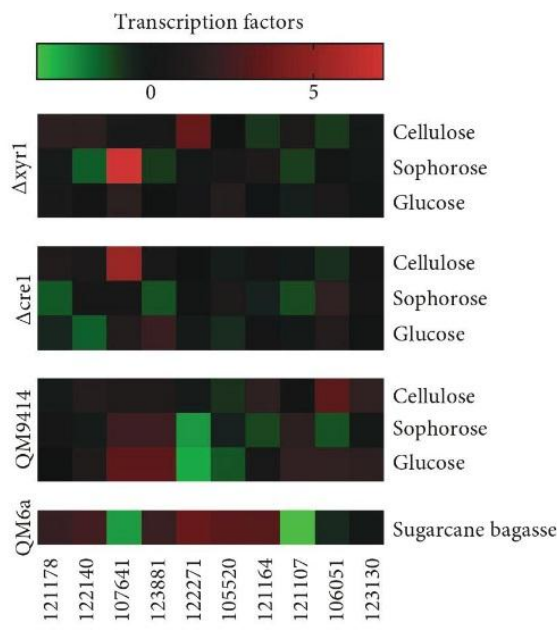

(b)

Figure 7: Heatmap expression of new players potentially involved with T. reesei biomass degradation. (a) Expression profile of copper transporter-encoding gene differentially expressed in $T$. reesei strains grown in cellulose, sophorose, glucose, and sugarcane bagasse. (b) Expression profile of transcription factor-encoding gene differentially expressed in T. reesei strains grown in cellulose, sophorose, glucose, and sugarcane bagasse. The results of gene expressions were transformed in Log2FoldChange values and employed to heat map construction using the GraphPad Prism version 7 program (https://www.graphpad.com/).

analysis [80, 141-143]. However, characterizing them according to the binding site and which gene expression it regulates is still necessary in order to have a greater knowledge of biomass degradation regulation. Therefore, the identification of novel transcription factors which transcription levels are affected by different carbon sources may be the first step for understanding more deeply how the regulation of transcription occurs. Therefore, these new findings could be used for engineering $T$. reesei in order to have a new hyperproducer strain for the industry to use in biomass degradation with higher efficiency.

\section{Conclusions}

The adoption of the filamentous fungus T. reesei as the most important holocellulase producer in biotechnology industries has been stabilized over the years. However, some aspects about holocellulase expression remain unclear. Thus, global transcriptional analyses are an excellent approach to understanding gene expression and promoting the selection of candidate genes for construction of strains producing high levels of holocellulases for plant cell wall degradation. This way, knowledge about the mechanisms involved in the recognition of environmental signals, sugar transport, and transcriptional regulatory events involved with fungal adaptation for different conditions consists in an extremely important step in the fungal biology comprehension. The integration of all these data might contribute to a better understanding of the regulatory mechanisms during lignocellulosic biomass degradation by $T$. reesei facilitating its application in fungal biotechnology.

\section{Conflicts of Interest}

The authors declare that there is no conflict of interest regarding the publication of this paper.

\section{Authors' Contributions}

Renato Graciano de Paula and Amanda Cristina Campos Antoniêto contributed equally to this work.

\section{Acknowledgments}

This work was supported by The State of São Paulo Research Foundation (FAPESP) (Processes 2016/20358-5, 2016/23233-9, and 2017/04206-3).

\section{References}

[1] G. J. Samuels, "Trichoderma: a review of biology and systematics of the genus," Mycological Research, vol. 100, no. 8, pp. 923-935, 1996 .

[2] V. K. Gupta, A. S. Steindorff, R. G. de Paula et al., "The post-genomic era of Trichoderma reesei: what's next?," Trends in Biotechnology, vol. 34, no. 12, pp. 970-982, 2016.

[3] G. E. Harman, A. H. Herrera-Estrella, B. A. Horwitz, and M. Lorito, "Special issue: Trichoderma-from basic biology to biotechnology," Microbiology, vol. 158, no. 1, pp. 1-2, 2012.

[4] A. Schuster and M. Schmoll, "Biology and biotechnology of Trichoderma," Applied Microbiology and Biotechnology, vol. 87, no. 3, pp. 787-799, 2010. 
[5] C. P. Kubicek, M. Komon-Zelazowska, and I. S. Druzhinina, "Fungal genus Hypocrea/Trichoderma: from barcodes to biodiversity," Journal of Zhejiang University Science B, vol. 9, no. 10, pp. 753-763, 2008.

[6] D. Tisch and M. Schmoll, "Targets of light signalling in Trichoderma reesei," BMC Genomics, vol. 14, no. 1, p. 657, 2013.

[7] A. Schuster, C. P. Kubicek, M. A. Friedl, I. S. Druzhinina, and M. Schmoll, "Impact of light on Hypocrea jecorina and the multiple cellular roles of ENVOY in this process," $B M C$ Genomics, vol. 8, no. 1, p. 449, 2007.

[8] I. Druzhinina and C. P. Kubicek, "Species concepts and biodiversity in Trichoderma and Hypocrea: from aggregate species to species clusters?," Journal of Zhejiang University Science B, vol. 6, no. 2, pp. 100-112, 2005.

[9] G. E. Harman, "Overview of mechanisms and uses of Trichoderma spp," Phytopathology, vol. 96, no. 2, pp. 190-194, 2006.

[10] Y. Galante, A. De Conti, and R. Monteverdi, Application of Trichoderma Enzymes in the Food and Feed Industries, G. E. Harman and C. P. Kubicek, Eds., Taylor and Francis, London, 1998.

[11] Y. Galante, A. De Conti, and R. Monteverdi, Application of Trichoderma Enzymes in the Textile Industry, G. E. Harman and C. P. Kubicek, Eds., Taylor and Francis, London, 1998.

[12] J. Buchert, T. Oksanen, J. Pere, M. Siika-Aho, A. Suurnäkki, and L. Viikari, Applications of Trichoderma reesei Enzymes in the Pulp and Paper Industry, G. E. Harman and C. P. Kubicek, Eds., Taylor and Francis, London, 1998.

[13] S. Pereira, L. Maehara, C. Machado, and C. Farinas, "2G ethanol from the whole sugarcane lignocellulosic biomass," Biotechnology for Biofuels, vol. 8, no. 1, p. 44, 2015.

[14] R. H. Bischof, J. Ramoni, and B. Seiboth, "Cellulases and beyond: the first 70 years of the enzyme producer Trichoderma reesei," Microbial Cell Factories, vol. 15, no. 1, p. 106, 2016.

[15] Y. Li, C. Liu, F. Bai, and X. Zhao, "Overproduction of cellulase by Trichoderma reesei RUT C30 through batch-feeding of synthesized low-cost sugar mixture," Bioresource Technology, vol. 216, pp. 503-510, 2016.

[16] J. Huang, D. Chen, Y. Wei et al., "Direct ethanol production from lignocellulosic sugars and sugarcane bagasse by a recombinant Trichoderma reesei strain HJ48," The Scientific World Journal, vol. 2014, Article ID 798683, 8 pages, 2014.

[17] S. S. Adav and S. K. Sze, "Trichoderma secretome: an overview," in Biotechnology and Biology of Trichoderma, V. K. Gupta, M. Schmoll, A. Herrera-Estrella, R. S. Upadhyay, I. Druzhinina, and M. G. Tuohy, Eds., pp. 103-114, Elsevier, Waltham, 1st edition, 2014.

[18] H. Bazafkan, D. Tisch, and M. Schmoll, "Regulation of glycoside hydrolase expression in Trichoderma," in Biotechnology and Biology of Trichoderma, V. K. Gupta, M. Schmoll, A. Herrera-Estrella, R. Upadhyay, I. Druzhinina, and M. G. Tuohy, Eds., p. 527, Elsevier, 2014.

[19] J. Gao, Y. Qian, Y. Wang, Y. Qu, and Y. Zhong, "Production of the versatile cellulase for cellulose bioconversion and cellulase inducer synthesis by genetic improvement of Trichoderma reesei," Biotechnology for Biofuels, vol. 10, no. 1, p. 272, 2017.

[20] Q. Zhou, J. Xu, Y. Kou et al., "Differential involvement of $\beta$-glucosidases from Hypocrea jecorina in rapid induction of cellulase genes by cellulose and cellobiose," Eukaryotic Cell, vol. 11, no. 11, pp. 1371-1381, 2012.
[21] L. dos Santos Castro, W. Pedersoli, A. C. Antoniêto et al., "Comparative metabolism of cellulose, sophorose and glucose in Trichoderma reesei using high-throughput genomic and proteomic analyses," Biotechnology for Biofuels, vol. 7, no. 1, p. 41, 2014.

[22] C. P. Kubicek, A. Herrera-Estrella, V. Seidl-Seiboth et al., "Comparative genome sequence analysis underscores mycoparasitism as the ancestral life style of Trichoderma," Genome Biology, vol. 12, no. 4, article R40, 2011.

[23] L. dos Santos Castro, A. C. C. Antoniêto, W. R. Pedersoli, R. Silva-Rocha, G. F. Persinoti, and R. N. Silva, "Expression pattern of cellulolytic and xylanolytic genes regulated by transcriptional factors XYR1 and CRE1 are affected by carbon source in Trichoderma reesei," Gene Expression Patterns, vol. 14, no. 2, pp. 88-95, 2014.

[24] E. A. Znameroski, S. T. Coradetti, C. M. Roche et al., "Induction of lignocellulose-degrading enzymes in Neurospora crassa by cellodextrins," Proceedings of the National Academy of Sciences of the United States of America, vol. 109, no. 16, pp. 6012-6017, 2012.

[25] Z. Anwar, M. Gulfraz, and M. Irshad, "Agro-industrial lignocellulosic biomass a key to unlock the future bio-energy: a brief review," Journal of Radiation Research and Applied Sciences, vol. 7, no. 2, pp. 163-173, 2014.

[26] V. Vandenbossche, J. Brault, G. Vilarem et al., "A new lignocellulosic biomass deconstruction process combining thermo-mechano chemical action and bio-catalytic enzymatic hydrolysis in a twin-screw extruder," Industrial Crops and Products, vol. 55, pp. 258-266, 2014.

[27] J. K. Saini, R. Saini, and L. Tewari, "Lignocellulosic agriculture wastes as biomass feedstocks for second-generation bioethanol production: concepts and recent developments," 3 Biotech, vol. 5, no. 4, pp. 337-353, 2015.

[28] C. A. Cardona, J. A. Quintero, and I. C. Paz, "Production of bioethanol from sugarcane bagasse: status and perspectives," Bioresource Technology, vol. 101, no. 13, pp. 4754-4766, 2010.

[29] A. V. Gusakov, "Alternatives to Trichoderma reesei in biofuel production," Trends in Biotechnology, vol. 29, no. 9, pp. 419-425, 2011.

[30] L. R. Lynd, W. H. van Zyl, J. E. Mcbride, and M. Laser, "Consolidated bioprocessing of cellulosic biomass: an update," Current Opinion in Biotechnology, vol. 16, no. 5, pp. 577-583, 2005.

[31] L. R. Lynd, P. J. Weimer, W. H. van Zyl, and I. S. Pretorius, "Microbial cellulose utilization: fundamentals and biotechnology," Microbiology and Molecular Biology Reviews, vol. 66, no. 3, pp. 506-577, 2002.

[32] Y. Shida, T. Furukawa, and W. Ogasawara, "Deciphering the molecular mechanisms behind cellulase production in Trichoderma reesei, the hyper-cellulolytic filamentous fungus," Bioscience, Biotechnology, and Biochemistry, vol. 80, no. 9, pp. 1712-1729, 2016.

[33] D. Martinez, R. M. Berka, B. Henrissat et al., "Genome sequencing and analysis of the biomass-degrading fungus Trichoderma reesei (syn. Hypocrea jecorina)," Nature Biotechnology, vol. 26, no. 5, pp. 553-560, 2008.

[34] M. Schmoll, C. Dattenböck, N. Carreras-Villaseñor et al., "The genomes of three uneven siblings: footprints of the lifestyles of three Trichoderma species," Microbiology and Molecular Biology Reviews, vol. 80, no. 1, pp. 205-327, 2016. 
[35] L. dos Santos Castro, R. G. de Paula, A. C. C. Antoniêto, G. F. Persinoti, R. Silva-Rocha, and R. N. Silva, "Understanding the role of the master regulator XYR1 in Trichoderma reesei by global transcriptional analysis," Frontiers in Microbiology, vol. 7, p. 175, 2016.

[36] R. J. Quinlan, M. D. Sweeney, L. Lo Leggio et al., "Insights into the oxidative degradation of cellulose by a copper metalloenzyme that exploits biomass components," Proceedings of the National Academy of Sciences of the United States of America, vol. 108, no. 37, pp. 15079-15084, 2011.

[37] M. Saloheimo, M. Paloheimo, S. Hakola et al., "Swollenin, a Trichoderma reesei protein with sequence similarity to the plant expansins, exhibits disruption activity on cellulosic materials," European Journal of Biochemistry, vol. 269, no. 17, pp. 4202-4211, 2002.

[38] M. Häkkinen, M. Arvas, M. Oja et al., "Re-annotation of the CAZy genes of Trichoderma reesei and transcription in the presence of lignocellulosic substrates," Microbial Cell Factories, vol. 11, no. 1, p. 134, 2012.

[39] I. S. Druzhinina and C. P. Kubicek, "Genetic engineering of Trichoderma reesei cellulases and their production," Microbial Biotechnology, vol. 10, no. 6, pp. 1485-1499, 2017.

[40] S. K. Brady, S. Sreelatha, Y. Feng, S. P. S. Chundawat, and M. J. Lang, "Cellobiohydrolase 1 from Trichoderma reesei degrades cellulose in single cellobiose steps," Nature Communications, vol. 6, no. 1, p. 10149, 2015.

[41] V. K. Gupta, Biotechnology and Biology of Trichoderma, Elsevier, 2014.

[42] J. Strakowska, L. Błaszczyk, and J. Chełkowski, "The significance of cellulolytic enzymes produced by Trichoderma in opportunistic lifestyle of this fungus," Journal of Basic Microbiology, vol. 54, no. S1, pp. S2-S13, 2014.

[43] R. G. De Paula, Characterization of the MAPK-dependent signaling pathway in the regulation of cellulase expression by the fungus Trichoderma reesei (Hypocrea jecorina), University of Sao Paulo, 2017.

[44] A. C. Campos Antoniêto, R. Graciano de Paula, L. d. Santos Castro, R. Silva-Rocha, G. Felix Persinoti, and R. Nascimento Silva, "Trichoderma reesei CRE1-mediated carbon catabolite repression in response to sophorose through RNA sequencing analysis," Current Genomics, vol. 17, no. 2, pp. 119-131, 2016.

[45] A. C. C. Antoniêto, L. dos Santos Castro, R. Silva-Rocha, G. F. Persinoti, and R. N. Silva, "Defining the genome-wide role of CRE1 during carbon catabolite repression in Trichoderma reesei using RNA-Seq analysis," Fungal Genetics and Biology, vol. 73, pp. 93-103, 2014

[46] C. P. Kubicek, R. Messner, F. Gruber, M. Mandels, and E. M. Kubicek-Pranz, "Triggering of cellulase biosynthesis by cellulose in Trichoderma reesei: involvement of a constitutive, sophorose-inducible, glucose-inhibited $\beta$-diglucoside permease," Journal of Biological Chemistry, vol. 268, no. 26, pp. 19364-19368, 1993.

[47] C. P. Kubicek, R. Messner, F. Gruber, R. L. Mach, and E. M. Kubicek-Pranz, "The Trichoderma cellulase regulatory puzzle: from the interior life of a secretory fungus," Enzyme and Microbial Technology, vol. 15, no. 2, pp. 90-99, 1993.

[48] W. Zhang, Y. Kou, J. Xu et al., "Two major facilitator superfamily sugar transporters from Trichoderma reesei and their roles in induction of cellulase biosynthesis," Journal of Biological Chemistry, vol. 288, no. 46, pp. 32861-32872, 2013.
[49] E. M. Quistgaard, C. Löw, F. Guettou, and P. Nordlund, "Understanding transport by the major facilitator superfamily (MFS): structures pave the way," Nature Reviews Molecular Cell Biology, vol. 17, no. 2, pp. 123-132, 2016.

[50] S. S. Pao, I. T. Paulsen, and M. H. Saier Jr., "Major facilitator superfamily," Microbiology and Molecular Biology Reviews, vol. 62 , no. 1, pp. 1-34, 1998.

[51] P. Cai, R. Gu, B. Wang et al., "Evidence of a critical role for cellodextrin transporte 2 (CDT-2) in both cellulose and hemicellulose degradation and utilization in Neurospora crassa," PLoS One, vol. 9, no. 2, article e89330, 2014.

[52] J. d. O. Porciuncula, T. Furukawa, Y. Shida et al., "Identification of major facilitator transporters involved in cellulase production during lactose culture of Trichoderma reese PC-3-7," Bioscience, Biotechnology, and Biochemistry, vol. 77, no. 5, pp. 1014-1022, 2014.

[53] C. Ivanova, J. A. Bååth, B. Seiboth, and C. P. Kubicek, "Systems analysis of lactose metabolism in Trichoderma reesei identifies a lactose permease that is essential for cellulase induction," PLoS One, vol. 8, no. 5, article e62631, 2013.

[54] N. Chaudhary, I. Kumari, P. Sandhu, M. Ahmed, and Y. Akhter, "Proteome scale census of major facilitator superfamily transporters in Trichoderma reesei using protein sequence and structure based classification enhanced ranking," Gene, vol. 585, no. 1, pp. 166-176, 2016.

[55] W. Vongsangnak, M. Salazar, K. Hansen, and J. Nielsen, "Genome-wide analysis of maltose utilization and regulation in aspergilli," Microbiology, vol. 155, no. 12, pp. 3893-3902 2009.

[56] J. E. Galagan, S. E. Calvo, K. A. Borkovich et al., "The genome sequence of the filamentous fungus Neurospora crassa," Nature, vol. 422, no. 6934, pp. 859-868, 2003.

[57] C. J. Law, P. C. Maloney, and D.-N. Wang, "Ins and outs of major facilitator superfamily antiporters," Annual Review of Microbiology, vol. 62, no. 1, pp. 289-305, 2008.

[58] N. Yan, "Structural advances for the major facilitator superfamily (MFS) transporters," Trends in Biochemical Sciences, vol. 38, no. 3, pp. 151-159, 2013.

[59] A. C. Colabardini, L. N. Ries, N. Brown et al., "Functional characterization of a xylose transporter in Aspergillus nidulans," Biotechnology for Biofuels, vol. 7, no. 1, p. 46, 2014.

[60] W. Zhang, Y. Cao, J. Gong, X. Bao, G. Chen, and W. Liu, "Identification of residues important for substrate uptake in a glucose transporter from the filamentous fungus Trichoderma reesei," Scientific Reports, vol. 5, no. 1, article 13829, 2015.

[61] Z. B. Huang, X. Z. Chen, L. N. Qin, H. Q. Wu, X. Y. Su, and Z. Y. Dong, "A novel major facilitator transporter TrSTR1 is essential for pentose utilization and involved in xylanase induction in Trichoderma reesei," Biochemical and Biophysical Research Communications, vol. 460, no. 3, pp. 663-669, 2015.

[62] L. Ries, S. T. Pullan, S. Delmas, S. Malla, M. J. Blythe, and D. B. Archer, "Genome-wide transcriptional response of Trichoderma reesei to lignocellulose using RNA sequencing and comparison with Aspergillus niger," BMC Genomics, vol. 14, no. 1, p. 541, 2013.

[63] L. Atanasova, S. L. Crom, S. Gruber et al., "Comparative transcriptomics reveals different strategies of Trichoderma mycoparasitism," BMC Genomics, vol. 14, no. 1, p. 121, 2013. 
[64] J. Kang, J.-U. Hwang, M. Lee et al., "PDR-type ABC transporter mediates cellular uptake of the phytohormone abscisic acid," Proceedings of the National Academy of Sciences of the United States of America, vol. 107, no. 5, pp. 2355-2360, 2010.

[65] R. Bischof, L. Fourtis, A. Limbeck, C. Gamauf, B. Seiboth, and C. P. Kubicek, "Comparative analysis of the Trichoderma reesei transcriptome during growth on the cellulase inducing substrates wheat straw and lactose," Biotechnology for Biofuels, vol. 6, no. 1, p. 127, 2013.

[66] E. Lamping, P. V. Baret, A. R. Holmes, B. C. Monk, A. Goffeau, and R. D. Cannon, "Fungal PDR transporters: phylogeny, topology, motifs and function," Fungal Genetics and Biology, vol. 47, no. 2, pp. 127-142, 2010.

[67] M. Ruocco, S. Lanzuise, F. Vinale et al., "Identification of a new biocontrol gene in Trichoderma atroviride: the role of an $\mathrm{ABC}$ transporter membrane pump in the interaction with different plant-pathogenic fungi," Molecular Plant-Microbe Interactions, vol. 22, no. 3, pp. 291-301, 2009.

[68] M. Karlsson, M. B. Durling, J. Choi et al., "Insights on the evolution of mycoparasitism from the genome of Clonostachys rosea," Genome Biology and Evolution, vol. 7, no. 2, pp. $465-480,2015$.

[69] S. Wilkens, "Structure and mechanism of ABC transporters," F1000Prime Reports, vol. 7, p. 14, 2015.

[70] M. G. L. Elferink, S. V. Albers, W. N. Konings, and A. J. M. Driessen, "Sugar transport in Sulfolobus solfataricus is mediated by two families of binding protein-dependent ABC transporters," Molecular Microbiology, vol. 39, no. 6, pp. 1494-1503, 2001.

[71] A. Watanabe, K. Hiraga, M. Suda, H. Yukawa, and M. Inui, "Functional characterization of Corynebacterium alkanolyticum $\beta$-xylosidase and xyloside $\mathrm{ABC}$ transporter in Corynebacterium glutamicum," Applied and Environmental Microbiology, vol. 81, no. 12, pp. 4173-4183, 2015.

[72] S. M. Koning, M. G. L. Elferink, W. N. Konings, and A. J. M. Driessen, "Cellobiose uptake in the hyperthermophilic archaeon Pyrococcus furiosus is mediated by an inducible, high-affinity ABC transporter," Journal of Bacteriology, vol. 183, no. 17, pp. 4979-4984, 2001.

[73] T. Furukawa, Y. Shida, N. Kitagami et al., "Identification of specific binding sites for XYR1, a transcriptional activator of cellulolytic and xylanolytic genes in Trichoderma reesei," Fungal Genetics and Biology, vol. 46, no. 8, pp. 564-574, 2009.

[74] T. Nakari-Setala, M. Paloheimo, J. Kallio, J. Vehmaanpera, M. Penttila, and M. Saloheimo, "Genetic modification of carbon catabolite repression in Trichoderma reesei for improved protein production," Applied and Environmental Microbiology, vol. 75, no. 14, pp. 4853-4860, 2009.

[75] T. Portnoy, A. Margeot, R. Linke et al., "The CRE1 carbon catabolite repressor of the fungus Trichoderma reesei: a master regulator of carbon assimilation," BMC Genomics, vol. 12, no. 1, p. 269, 2011.

[76] T. Portnoy, A. Margeot, V. Seidl-Seiboth et al., "Differential regulation of the cellulase transcription factors XYR1, ACE2, and ACE1 in Trichoderma reesei strains producing high and low levels of cellulase," Eukaryotic Cell, vol. 10, no. 2, pp. 262-271, 2011.

[77] E. Akel, B. Metz, B. Seiboth, and C. P. Kubicek, "Molecular regulation of arabinan and L-arabinose metabolism in Нypocrea jecorina (Trichoderma reesei)," Eukaryotic Cell, vol. 8, no. 12, pp. 1837-1844, 2009.
[78] A. R. Stricker, K. Grosstessner-Hain, E. Wurleitner, and R. L. Mach, "Xyr1 (xylanase regulator 1) regulates both the hydrolytic enzyme system and D-xylose metabolism in Hypocrea jecorina," Eukaryotic Cell, vol. 5, no. 12, pp. 2128-2137, 2006.

[79] N. Aro, A. Saloheimo, M. Ilmén, and M. Penttilä, "ACEII, a novel transcriptional activator involved in regulation of cellulase and xylanase genes of Trichoderma reesei," The Journal of Biological Chemistry, vol. 276, no. 26, pp. 24309-24314, 2001.

[80] M. Häkkinen, M. J. Valkonen, A. Westerholm-Parvinen et al., "Screening of candidate regulators for cellulase and hemicellulase production in Trichoderma reesei and identification of a factor essential for cellulase production," Biotechnology for Biofuels, vol. 7, no. 1, p. 14, 2014.

[81] S. Zeilinger, M. Schmoll, M. Pail, R. L. Mach, and C. P. Kubicek, "Nucleosome transactions on the Hypocrea jecorina (Trichoderma reesei) cellulase promoter $c b h 2$ associated with cellulase induction," Molecular Genetics and Genomics, vol. 270, no. 1, pp. 46-55, 2003.

[82] M. Nitta, T. Furukawa, Y. Shida et al., "A new $\mathrm{Zn}(\mathrm{II})_{2} \mathrm{Cys}_{6}{ }^{-}$ type transcription factor BglR regulates $\beta$-glucosidase expression in Trichoderma reesei," Fungal Genetics and Biology, vol. 49, no. 5, pp. 388-397, 2012.

[83] B. Seiboth, R. A. Karimi, P. A. Phatale et al., "The putative protein methyltransferase LAE1 controls cellulase gene expression in Trichoderma reesei," Molecular Microbiology, vol. 84, no. 6, pp. 1150-1164, 2012.

[84] R. Karimi Aghcheh, Z. Németh, L. Atanasova et al., "The VELVET A orthologue VEL1 of Trichoderma reesei regulates fungal development and is essential for cellulase gene expression," PLoS One, vol. 9, no. 11, article e112799, 2014.

[85] N. Aro, M. Ilmen, A. Saloheimo, and M. Penttila, "ACEI of Trichoderma reesei is a repressor of cellulase and xylanase expression," Applied and Environmental Microbiology, vol. 69 , no. 1, pp. 56-65, 2003.

[86] Y. Cao, F. Zheng, L. Wang et al., "Rce1, a novel transcriptional repressor, regulates cellulase gene expression by antagonizing the transactivator Xyr1 in Trichoderma reesei," Molecular Microbiology, vol. 105, no. 1, pp. 65-83, 2017.

[87] L. Ries, N. J. Belshaw, M. Ilmén, M. E. Penttilä, M. Alapuranen, and D. B. Archer, "The role of CRE1 in nucleosome positioning within the cbh1 promoter and coding regions of Trichoderma reesei," Applied Microbiology and Biotechnology, vol. 98, no. 2, pp. 749-762, 2014.

[88] B. Van Vu, K. T. M. Pham, and H. Nakayashiki, "Substrateinduced transcriptional activation of the MoCel7C cellulase gene is associated with methylation of histone $\mathrm{H} 3$ at lysine 4 in the rice blast fungus Magnaporthe oryzae," Applied and Environmental Microbiology, vol. 79, no. 21, pp. 6823-6832, 2013.

[89] Q. Xin, Y. Gong, X. Lv, G. Chen, and W. Liu, "Trichoderma reese $i$ histone acetyltransferase $\mathrm{Gcn} 5$ regulates fungal growth, conidiation, and cellulase gene expression," Current Microbiology, vol. 67, no. 5, pp. 580-589, 2013.

[90] H. Hirasawa, K. Shioya, T. Furukawa et al., "Engineering of the Trichoderma reesei xylanase 3 promoter for efficient enzyme expression," Applied Microbiology and Biotechnology, vol. 102, no. 6, pp. 2737-2752, 2018.

[91] G. Zou, S. Shi, Y. Jiang et al., "Construction of a cellulase hyper-expression system in Trichoderma reesei by promoter and enzyme engineering," Microbial Cell Factories, vol. 11, no. 1, p. 21, 2012. 
[92] F. Uzbas, U. Sezerman, L. Hartl, C. P. Kubicek, and B. Seiboth, "A homologous production system for Trichoderma reesei secreted proteins in a cellulase-free background," Applied Microbiology and Biotechnology, vol. 93, no. 4, pp. 1601-1608, 2012.

[93] T. Liu, T. Wang, X. Li, and X. Liu, "Improved heterologous gene expression in Trichoderma reesei by cellobiohydrolase I gene $(c b h 1)$ promoter optimization," Acta Biochimica et Biophysica Sinica, vol. 40, no. 2, pp. 158-165, 2008.

[94] Y.-S. Bahn, C. Xue, A. Idnurm, J. C. Rutherford, J. Heitman, and M. E. Cardenas, "Sensing the environment: lessons from fungi," Nature Reviews Microbiology, vol. 5, no. 1, pp. 57-69, 2007.

[95] M. Schmoll, "The information highways of a biotechnological workhorse-signal transduction in Hypocrea jecorina," BMC Genomics, vol. 9, no. 1, p. 430, 2008.

[96] M. Saloheimo and T. M. Pakula, "The cargo and the transport system: secreted proteins and protein secretion in Trichoderma reesei (Hypocrea jecorina)," Microbiology, vol. 158, no. 1, pp. 46-57, 2012.

[97] J. Zhang, Y. Zhang, Y. Zhong, Y. Qu, and T. Wang, "Ras GTPases modulate morphogenesis, sporulation and cellulase gene expression in the cellulolytic fungus Trichoderma reesei," PLoS One, vol. 7, no. 11, article e48786, 2012.

[98] S. Zeilinger, B. Reithner, V. Scala, I. Peissl, M. Lorito, and R. L. Mach, "Signal transduction by Tga3, a novel G protein alpha subunit of Trichoderma atroviride," Applied and Environmental Microbiology, vol. 71, no. 3, pp. 1591-1597, 2005.

[99] C. A. D'Souza and J. Heitman, "Conserved cAMP signaling cascades regulate fungal development and virulence," FEMS Microbiology Reviews, vol. 25, no. 3, pp. 349-364, 2001

[100] T. Vasara, M. Saloheimo, S. Keränen, and M. Penttilä, "Trichoderma reesei rho3, a homologue of yeast $\mathrm{RHO}$, suppresses the growth defect of yeast sec15-1 mutation," Current Genetics, vol. 40, no. 2, pp. 119-127, 2001.

[101] R. Morawetz, H. Mischak, J. Goodnight, T. Lendenfeld, J. F. Mushinsky, and C. P. Kubicek, "A protein kinaseencoding gene, $p k t l$, from Trichoderma reesei, homologous to the yeast YPK1 and YPK2 (YKR2) genes," Gene, vol. 146, no. 2, pp. 309-310, 1994.

[102] R. Morawetz, T. Lendenfeld, H. Mischak et al., "Cloning and characterisation of genes ( $p k c 1$ and $p k c A$ ) encoding protein kinase $\mathrm{C}$ homologues from Trichoderma reesei and Aspergillus niger," Molecular and General Genetics MGG, vol. 250, no. 1 , pp. 17-28, 1996.

[103] T. Lendenfeld and P. C. Kubicek, "Characterization and properties of protein kinase $\mathrm{C}$ from the filamentous fungus Trichoderma reesei," Biochemical Journal, vol. 330, no. 2, pp. 689-694, 1998.

[104] M. Wang, M. Zhang, L. Li et al., "Role of Trichoderma reesei mitogen-activated protein kinases (MAPKs) in cellulase formation," Biotechnology for Biofuels, vol. 10, no. 1, p. 99, 2017.

[105] C. Seibel, G. Gremel, R. do Nascimento Silva, A. Schuster, C. P. Kubicek, and M. Schmoll, "Light-dependent roles of the G-protein $\alpha$ subunit GNA1 of Hypocrea jecorina (anamorph Trichoderma reesei)," BMC Biology, vol. 7, no. 1, p. $58,2009$.

[106] M. Schmoll, A. Schuster, R. N. Silva, and C. P. Kubicek, "The G-alpha protein GNA3 of Hypocrea jecorina (Anamorph Trichoderma reesei) regulates cellulase gene expression in the presence of light," Eukaryotic Cell, vol. 8, no. 3, pp. 410420, 2009.

[107] K. Brunner, M. Omann, M. E. Pucher et al., "Trichoderma G protein-coupled receptors: functional characterisation of a cAMP receptor-like protein from Trichoderma atroviride," Current Genetics, vol. 54, no. 6, pp. 283-299, 2008.

[108] M. R. Omann, S. Lehner, C. Escobar Rodriguez, K. Brunner and S. Zeilinger, "The seven-transmembrane receptor Gpr1 governs processes relevant for the antagonistic interaction of Trichoderma atroviride with its host," Microbiology, vol. 158, no. 1, pp. 107-118, 2012.

[109] D. Tisch, C. P. Kubicek, and M. Schmoll, "The phosducin-like protein PhLP1 impacts regulation of glycoside hydrolases and light response in Trichoderma reesei," BMC Genomics, vol. 12, no. 1, p. 613, 2011.

[110] S. Sestak and V. Farkas, "Metabolic regulation of endoglucanase synthesis in Trichoderma reesei: participation of cyclic AMP and glucose-6-phosphate," Canadian Journal of Microbiology, vol. 39, no. 3, pp. 342-347, 1993.

[111] K. M. V. Nogueira, M. d. N. Costa, R. G. de Paula, F. C. Mendonça-Natividade, R. Ricci-Azevedo, and R. N. Silva, "Evidence of cAMP involvement in cellobiohydrolase expression and secretion by Trichoderma reesei in presence of the inducer sophorose," BMC Microbiology, vol. 15 no. 1, p. $195,2015$.

[112] A. Schuster, D. Tisch, V. Seidl-Seiboth, C. P. Kubicek, and M. Schmoll, "Roles of protein kinase A and adenylate cyclase in light-modulated cellulase regulation in Trichoderma reesei," Applied and Environmental Microbiology, vol. 78, no. 7, pp. 2168-2178, 2012.

[113] M. Wang, H. Yang, M. Zhang et al., "Functional analysis of Trichoderma reesei CKII $\alpha 2$, a catalytic subunit of casein kinase II," Applied Microbiology and Biotechnology, vol. 99, no. 14 , pp. 5929-5938, 2015.

[114] R. He, W. Guo, and D. Zhang, "An ethanolamine kinase Ekil affects radial growth and cell wall integrity in Trichoderma reesei," FEMS Microbiology Letters, vol. 362, no. 17, article fnv133, 2015.

[115] M. Wang, Q. Zhao, J. Yang et al., “A mitogen-activated protein kinase Tmk3 participates in high osmolarity resistance, cell wall integrity maintenance and cellulase produc tion regulation in Trichoderma reesei," PLoS One, vol. 8, no. 8, article e 72189,2013

[116] M. Wang, Y. Dong, Q. Zhao et al., "Identification of the role of a MAP kinase Tmk2 in Hypocrea jecorina (Trichoderma reesei)," Scientific Reports, vol. 4, no. 1, article 6732 , 2015.

[117] F. Chen, X. Z. Chen, X. Y. Su et al., "An Ime2-like mitogenactivated protein kinase is involved in cellulase expression in the filamentous fungus Trichoderma reesei," Biotechnology Letters, vol. 37, no. 10, pp. 2055-2062, 2015.

[118] D. E. Clapham, "Calcium signaling," Cell, vol. 131, no. 6 , pp. 1047-1058, 2007.

[119] L Navazio, B. Baldan, R. Moscatiello et al, "Calciummediated perception and defense responses activated in plant cells by metabolite mixtures secreted by the biocontrol fungus Trichoderma atroviride," BMC Plant Biology, vol. 7, no. 1, p. 41, 2007.

[120] R. L. Mach, S. Zeilinger, D. Kristufek, and C. P. Kubicek, " $\mathrm{Ca}^{2+}$-calmodulin antagonists interfere with xylanase formation and secretion in Trichoderma reesei," Biochimica et 
Biophysica Acta (BBA) - Molecular Cell Research, vol. 1403, no. 3, pp. 281-289, 1998.

[121] D. Tisch, C. P. Kubicek, and M. Schmoll, "New insights into the mechanism of light modulated signaling by heterotrimeric G-proteins: ENVOY acts on gna1 and gna3 and adjusts cAMP levels in Trichoderma reesei (Hypocrea jecorina)," Fungal Genetics and Biology, vol. 48, no. 6, pp. 631-640, 2011.

[122] A. Cziferszky, R. L. Mach, and C. P. Kubicek, "Phosphorylation positively regulates DNA binding of the carbon catabolite repressor Crel of Hypocrea jecorina (Trichoderma reesei)," The Journal of Biological Chemistry, vol. 277, no. 17, pp. 14688-14694, 2002.

[123] I. E. Cabrera, I. V. Pacentine, A. Lim et al., "Global analysis of predicted $G$ protein-coupled receptor genes in the filamentous fungus, Neurospora crassa," G3: Genes, Genomes, Genetics, vol. 5, no. 12, pp. 27292743, 2015.

[124] P. E. Vercoe, S. A. Kocherginskaya, and B. A. White, "Differential protein phosphorylation-dephosphorylation in response to carbon source in Ruminococcus flavefaciens FD-1," Journal of Applied Microbiology, vol. 94, no. 6, pp. 974-980, 2003.

[125] D. Tisch and M. Schmoll, "Novel approaches to improve cellulase biosynthesis for biofuel production-adjusting signal transduction pathways in the biotechnological workhorse Trichoderma reesei," in Biofuel Production--Recent Developments and Prospects, M. A. Santos Bernardes, Ed., pp. 199-224, Intech, Rijeka, Croatia, 2011.

[126] T. M. Mello-de-Sousa, A. Rassinger, M. E. Pucher et al., "The impact of chromatin remodelling on cellulase expression in Trichoderma reesei," BMC Genomics, vol. 16, no. 1, p. 588, 2015.

[127] G. P. Borin, C. C. Sanchez, A. P. de Souza et al., "Comparative secretome analysis of Trichoderma reesei and Aspergillus Niger during growth on sugarcane biomass," PLoS One, vol. 10, no. 6, article e0129275, 2015

[128] R. Peterson and H. Nevalainen, "Trichoderma reesei RUTC30-thirty years of strain improvement," Microbiology, vol. 158 , no. 1, pp. 58-68, 2012.

[129] R. K. Aghcheh and C. P. Kubicek, "Epigenetics as an emerging tool for improvement of fungal strains used in biotechnology," Applied Microbiology and Biotechnology, vol. 99, no. 15, pp. 6167-6181, 2015.

[130] A. B. Sanz, R. García, J. M. Rodríguez-Peña, C. Nombela, and J. Arroyo, "Cooperation between SAGA and SWI/SNF complexes is required for efficient transcriptional responses regulated by the yeast MAPK Slt2," Nucleic Acids Research, vol. 44, pp. 7159-7172, 2016.

[131] R. M. Duran, S. Gregersen, T. D. Smith et al., "The role of Aspergillus flavus veA in the production of extracellular proteins during growth on starch substrates," Applied Microbiology and Biotechnology, vol. 98, no. 11, pp. 5081-5094, 2014 .

[132] J. Schumacher, A. Simon, K. C. Cohrs et al., "The VELVET complex in the gray mold fungus Botrytis cinerea: impact of BcLAE1 on differentiation, secondary metabolism, and virulence," Molecular Plant-Microbe Interactions, vol. 28, no. 6, pp. 659-674, 2015.

[133] N. Trushina, M. Levin, P. K. Mukherjee, and B. A. Horwitz, "PacC and $\mathrm{pH}$-dependent transcriptome of the mycotrophic fungus Trichoderma virens," BMC Genomics, vol. 14, no. 1, p. $138,2013$.

[134] F. Castellanos, M. Schmoll, P. Martínez et al., "Crucial factors of the light perception machinery and their impact on growth and cellulase gene transcription in Trichoderma reesei," Fungal Genetics and Biology, vol. 47, no. 5, pp. 468 $476,2010$.

[135] M. Schmoll, L. Franchi, and C. P. Kubicek, "Envoy, a PAS LOV domain protein of Hypocrea jecorina (Anamorph Trichoderma reesei), modulates cellulase gene transcription in response to light," Eukaryotic Cell, vol. 4, no. 12, pp. 1998-2007, 2005.

[136] W. Dong, Q. Yinbo, and G. Peiji, "Regulation of cellulase synthesis in mycelial fungi: participation of ATP and cyclic AMP," Biotechnology Letters, vol. 17, no. 6, pp. 593-598, 1995.

[137] G. P. Borin, C. C. Sanchez, E. S. de Santana et al., "Comparative transcriptome analysis reveals different strategies for degradation of steam-exploded sugarcane bagasse by Aspergillus niger and Trichoderma reesei," BMC Genomics, vol. 18, no. 1, p. 501, 2017.

[138] J. S. Bak, "Lignocellulose depolymerization occurs via an environmentally adapted metabolic cascades in the wood rotting basidiomycete Phanerochaete chrysosporium," Microbiology, vol. 4, no. 1, pp. 151-166, 2015.

[139] G. R. Hemsworth, E. M. Johnston, G. J. Davies, and P. H. Walton, "Lytic polysaccharide monooxygenases in biomass conversion," Trends in Biotechnology, vol. 33, no. 12, pp. 747-761, 2015.

[140] W. C. Kim, J. Y. Kim, J. H. Ko, H. Kang, and K. H. Han, "Identification of direct targets of transcription factor MYB46 provides insights into the transcriptional regulation of secondary wall biosynthesis," Plant Molecular Biology, vol. 85 , no. 6 , pp. 589-599, 2014.

[141] Y. Xiong, V. W. Wu, A. Lubbe et al., "A fungal transcription factor essential for starch degradation affects integration of carbon and nitrogen metabolism," PLoS Genetics, vol. 13, no. 5, article e1006737, 2017.

[142] S. T. Coradetti, J. P. Craig, Y. Xiong, T. Shock, C. Tian, and N. L. Glass, "Conserved and essential transcription factors for cellulase gene expression in ascomycete fungi," Proceedings of the National Academy of Sciences, vol. 109, no. 19, pp. 7397-7402, 2012.

[143] P. K. Foreman, D. Brown, L. Dankmeyer et al., "Transcriptional regulation of biomass-degrading enzymes in the filamentous fungus Trichoderma reesei," The Journal of Biological Chemistry, vol. 278, no. 34, pp. 31988-31997, 2003.

[144] F. Segato, A. R. Damásio, R. C. de Lucas, F. M. Squina, and R. A. Prade, "Genomics review of holocellulose deconstruction by aspergilli," Microbiology and Molecular Biology Reviews, vol. 78, no. 4, pp. 588-613, 2014.

[145] C. M. Payne, B. C. Knott, H. B. Mayes et al., "Fungal cellulases," Chemical Reviews, vol. 115, no. 3, pp. 1308-1448, 2015.

[146] A. Berlin, "No barriers to cellulose breakdown," Science, vol. 342 , no. 6165 , pp. 1454-1456, 2013. 
Capítulo II

\section{Considerações sobre o capítulo II}

No capítulo II, foi descrito os principais resultados de pesquisas provenientes do nosso grupo. Através de dados de RNA-seq e proteômica, novos componentes envolvidos na degradação da celulose, como proteínas com funções não-catalíticas secretadas em diferentes fontes de carbono, fatores de transcrição, enzimas carboidratoativas (CAZymes) e transportadores foram descritos.

Alguns dos transportadores identificados foram especificamente induzidos por celulose, soforose, glicose ou bagaço de cana, sendo que as permeases da família MFS (Major Facilitator Superfamily) foram as mais presentes nas diferentes fontes de carbono avaliadas.

O fator de transcrição XYR1, que regula positivamente a expressão de genes de celulases, parece induzir a expressão de genes que codificam para MFS permeases em presença de celulose, enquanto que em presença de glicose ocorre a repressão por CRE1. Além disso, em presença de bagaço de cana e glicose, a expressão dessas permeases parece ser regulada por proteínas TMK1 e TMK2, envolvidas na via de sinalização dependente de MAP quinases.

A identificação de MFS permeases em T. reesei durante o cultivo em diferentes fontes de carbono, foi fundamental para estudos posteriores de validação funcional e estudo do envolvimento de Tr69957, descrito no capítulo I, na degradação da biomassa lignocelulósica. 


\subsection{Capítulo III}

Diz respeito a manuscrito em fase de preparação com as especificações que se seguem.

Título: Probing membrane proteome of Trichoderma reesei to identify novel sugar transporters potentially involved during cellulose degradation.

Autores: Karoline Maria Vieira Nogueira, Anusha Cheruku, Ardeshir Amirkhani, Matthew Mackey, Helena Nevalainen, Marck P Molloy, Karthik Shantharam Kamath, Roberto do Nascimento Silva.

Periódico: Manuscrito em fase de preparação. 
Probing membrane proteome of Trichoderma reesei to identify novel sugar transporters potentially involved during cellulose degradation.

$\underline{\text { Karoline Maria Vieira Nogueira }}{ }^{1}$, Anusha Cheruku $^{3}$, Ardeshir Amirkhani $^{3}$, Matthew Mackey ${ }^{3}$, Helena Nevalainen ${ }^{2}$, Marck P Molloy ${ }^{4}$, Karthik Shantharam Kamath ${ }^{2}$, Roberto do Nascimento Silva ${ }^{1}$.

${ }^{1}$ Molecular Biotechnology Laboratory, Department of Biochemistry and Immunology, Ribeirao Preto Medical School (FMRP), University of Sao Paulo, Ribeirao Preto, SP, Brazil, ${ }^{2}$ Department of Molecular Sciences, Macquarie University, Sydney, NSW, Australia.

${ }^{3}$ Australian Proteome Analysis Facility, Macquarie University, Sydney, NSW, Australia.

${ }^{4}$ Sydney Medical School, The University of Sydney, Sydney, NSW, Australia.

\begin{abstract}
One of the major challenges of biotechnology is the development of biological processes that reduce the negative impacts on the environment caused by the burning of fossil fuels. In this context, biofuels have received attention in recent decades. Trichoderma reesei is among the main producers of lignocellulolytic enzymes, which are used in the conversion of lignocellulosic raw materials to fermentable sugars. Although there are advances in research related to the activation and production of these enzymes, little is known about the transport systems for the sugar uptake and the influence of these transporters on the degradation of the biomass. For better understanding the involvement of sugar transporters during the cellulose degradation, in this work, T. reesei QM9414 was grown in two different carbon sources; cellulose and glycerol, and different time intervals; 6, 24 and 48 hours for cellulose and 24 hours for glycerol. Through the $T$. reesei membrane-associated proteome analysis, we identified 14 sugar transporters during the culture of $T$. reesei in presence of glycerol and cellulose. Among this, 12 sugar transporters identified were present in all the conditions analyzed. Ten sugar transporters were down regulated in presence of glycerol and up regulated in presence of cellulose. We identified 9 uncharacterized sugar transporters that can be potentially involved during cellulose degradation and 5 sugar transporters already characterized in $T$. reesei. With this results, a future characterization of novel sugar transporters potentially involved during the cellulose deconstruction can be performed. In
\end{abstract}


Capítulo III

addition, this work will contribute to the development of new technologies that aim to optimize the process of obtaining bioethanol trough the engineering of high yielding cellulase strains of $T$. reesei.

Key words: Trichoderma reesei, Sugar transporters, proteome, cellulose.

\section{Introduction}

Since many decades, the search for renewable and economically viable energy sources alternative to petroleum-based energy, has propelled the research on the filamentous fungus Trichoderma reesei (BISCHOF; RAMONI; SEIBOTH, 2016). T. reesei naturally possesses versatile potential to produce and secrete a wide array of enzymes including cellulases, hemicellulases and other Carbohydrate-Active Enzymes (CAZymes) (CASTRO et al., 2014), which can be sustainably utilized in the production of biofuels from renewable sources, such as lignocellulosic biomass, often obtained from agricultural or waste residues (BISCHOF; RAMONI; SEIBOTH, 2016; SAINI; SAINI; TEWARI, 2015).

The major components of lignocellulosic biomass are cellulose, hemicellulose and lignin, wherein cellulose represents the most abundant component in the plant cell wall (GLASS et al., 2013). The conversion of this biomass into ethanol in a process called $2^{\text {nd }}$ generation $(2 \mathrm{G})$ biofuel production, occurs through different steps as pre-treatment, hydrolysis, fermentation and separation/recovery processes (ZABED et al., 2017). During the hydrolysis, the pre-treated lignocellulosic biomass is deconstructed into simple sugars, using enzymes produced industrially by filamentous fungi, in a process called saccharification (SAINI; SAINI; TEWARI, 2015). In this context, Trichoderma reesei represents the most important fungus for the industrial production of these enzymes and is widely used in the biotechnology industry for biofuels production (SEIBOTH; IVANOVA; SEIDL-SEIBOTH, 2011).

Although enzymes produced by filamentous fungi being broadly used in biofuel industry, the current process of saccharification is a costly and inefficient step (PAUL DALY, JOLANDA M. VAN MUNSTER, 2016). One of the routes to obtain new technologies to improve the efficiency of already existing step involves understanding the molecular mechanisms underpinning the cellular regulation of CAZymes-encoding genes, its secretory process and also the sensing and responses of filamentous fungi to lignocellulose (CARRERAS-VILLASENOR; SANCHEZ-ARREGUIN; HERRERA-ESTRELLA，2012; PAUL DALY, JOLANDA M. VAN MUNSTER, 2016; ZHANG et al., 2013). 
During the natural process of biomass hydrolysis by the fungus, a mixture of monosaccharides and disaccharides act as regulatory molecules of CAZymes-encoding genes in a process mediated by transcription factors. The expression of these genes can be induced by cellulose and other substances (e.g., xylose, sophorose, lactose), while glucose acts as a repressing carbon source (FURUKAWA et al., 2009; NAKARI-SETÄLÄ et al., 2009).

During the degradation of biomass, the capacity of T.reesei to sense insoluble cellulose in the environment, initiating the rapid synthesis of cellulases and the uptake of soluble sugars released from biomass hydrolysis is essential for the rapid production of the enzymatic machinery required to breakdown cellulose. Over time as the lignocellulose material is degraded, fungi are exposed to a succession of changing conditions (HÄKKINEN et al., 2012; PAUL DALY, JOLANDA M. VAN MUNSTER, 2016). It is possible that $T$. reesei sense cellulose through recognition of sugars by a transporter in the membrane (ZHANG et al., 2013). Besides that, the uptake of the soluble sugars by transporter proteins is promoting the transport of various small inducer molecules from the extracellular environment into the fungus influencing the expression of CAZymes encoding genes (CAI et al., 2014; IVANOVA et al., 2013; ORCIUNCULA et al., 2013).

Hence, understanding the role of sugar transporter proteins during the process of biomass degradation may provide an opportunity to control the induced molecular cascade. Although there are advances in the research about the production and secretion of CAZymes in $T$. reesei, the influence of the sugar transporters on biomass degradation is yet to be elucidated (DOS REIS et al., 2016; REIS et al., 2013).

T. reesei developed an efficient membrane transport system capable of transporting a wide range of carbon sources and ions. Interestingly, approximately 5\% (459 genes) of the $T$. reesei genome comprise genes that encode membrane transporter proteins (DOS SANTOS CASTRO et al., 2014) . Among these, the largest group of identified transporters belongs to the Major Facilitator Superfamily (MFS), class of sugar transporters (CHAUDHARY et al., 2016; DOS SANTOS CASTRO et al., 2016).

In T. reesei, as well as other filamentous fungi, MFS sugar transporters recognize and transport more than one type of sugars into the fungal cell. For instance, Stp1 (ZHANG et al., 2013) transporter is involved in glucose and cellobiose uptake and Tr69957 transporter (NOGUEIRA et al., 2018) is involved in mannose, cellobiose and xylose uptake.

Additionally, the sugar transporters from MFS family can play an important role in signaling the presence of cellulose and cellulase induction. The Crt1 transporter mediates the 
cellulolytic signaling independent of sugar transporting activity. The uptake of cellobiose or sophorose by $T$. reese $i$ was not impaired in the absence of this gene, but the presence of this gene was essential for its growth and show an enzymatic activity on cellulose or lactose (ZHANG et al., 2013). In T. reesei, the absence of Stp1 resulted in differential cellulolytic response to Avicel versus cellobiose. Furthermore, was demonstrated that Stp1 in some way repressed induction of major cellulase and hemicellulose genes in response to Avicel (ZHANG et al., 2013).

To better understand the roles of sugar transporters during the biomass degradation, we temporally profiled quantitative membrane proteome of $T$. reesei in response to two different carbon sources; cellulose and glycerol. We intended to create mechanistic understanding of how the known and novel sugar transporters, potentially responsible for sensing and transporting hydrolysates of cellulose, interact with each other and with the cell during this process. Importantly, this research presents a preliminary basis to carry out further studies on characterizing and engineering known and novel sugar transporters, with an aim to construct high yielding cellulase strains of T. reesei, to improve the production of bioethanol $(2 \mathrm{G})$.

\section{Methodology}

\section{II.1. Fungal strain and media}

T. reesei strain QM9414, was maintained on MEX medium (Malt extract 3\%, Agar $2 \%$ ) at $28^{\circ} \mathrm{C}$. The Mandels-Andreotti medium (SCHMOLL et al., 2009) (pH 5) was composed of mineral solution $(50 \%)$, trace elements $(2 \%), 0.3 \mathrm{~g} / \mathrm{L}$ urea, $1 \mathrm{~g} / \mathrm{L}$ peptone and a determined concentration of carbon source including cellulose and glycerol, according to our experimental conditions.

\section{II.2. Induction conditions}

T. reesei strain QM9414 was grown in solid Potato Dextrose Agar medium at $28{ }^{\circ} \mathrm{C}$ for 7 days. Initially, $10^{6}$ spores $\mathrm{mL}^{-1}$ of QM9414 strain were inoculated into $200 \mathrm{~mL}$ starting culture of Mandels-Andreotti medium containing 1\% glycerol. After 24 hours, the mycelium was transferred into $200 \mathrm{~mL}$ of Mandels-Andreotti medium containing $1 \%$ of microcrystalline cellulose.

The cultures were incubated on an orbital shaker $(200 \mathrm{rpm})$ at $28{ }^{\circ} \mathrm{C}$ for 6,24 and 48 hours for $1 \%$ microcrystalline cellulose experiments. All experiments were performed in 
biological triplicates $(n=3)$. The resulting mycelia were collected by filtration, frozen in liquid nitrogen, and stored at $-80{ }^{\circ} \mathrm{C}$ for membrane protein purification and LC-MS/MS.

\section{II.3. Membrane-associated protein purification}

The Membrane-associated protein purification was accomplished according to $\mathrm{J}$. Sloothaak et al (SLOOTHAAK et al., 2015) with modifications. Briefly, mycelium samples (2-3 g, press-dried) were mechanically disrupted by maceration in liquid nitrogen, using pestle and mortar, and resuspended in the $20 \mathrm{mM}$ HEPES buffer $\mathrm{pH} 7.6$ containing $150 \mathrm{mM}$ $\mathrm{NaCl}$ and Complete ${ }^{\mathrm{TM}}$, EDTA-free Protease Inhibitor Cocktail (Roche). Next, cell-free extracts were centrifuged for $5 \mathrm{~min}$ at low speed $(500 \mathrm{~g})$ to remove unbroken cells and precipitate debris. The supernatants were collected and then centrifuged for $20 \mathrm{~min}$ at medium speed (5000g) (Eppendorf Centrifuge 5810R), to precipitate and remove remaining heavy organelles. The remaining supernatants were centrifuged for $120 \mathrm{~min}$ at high speed $(\sim 85,000 \mathrm{~g})$ (Beckman Coulter Optima XPN). The precipitate obtained was resuspended with $100 \mathrm{mM}$ triethylammonium bicarbonate (TEAB) and sodium deoxycholate detergent (SDC) $1 \%$, mixed rigorously on a vortex mixer and incubated in a thermomixer for 5 minutes at $95^{\circ} \mathrm{C}, 800 \mathrm{rpm}$. The protein content of plasma membrane-associated fraction was determined using the Pierce ${ }^{\mathrm{TM}}$ BCA Protein Assay Kit as per manufacture's instructions (Figure 1A).

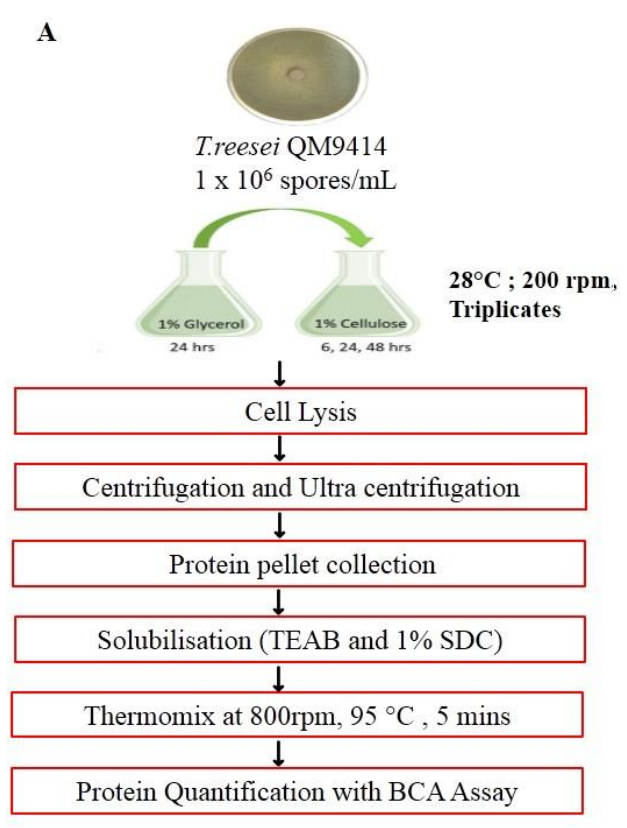

\section{B}

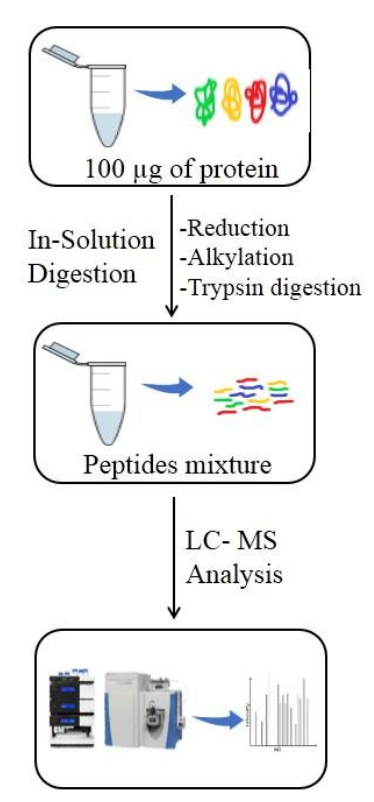

C
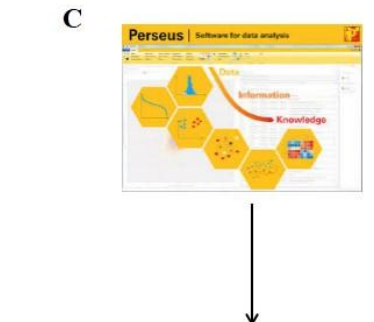

Proteins present in at least two biological replicates and $\geq 2$ peptides identified.

Protein quantities across respective conditions were compared using $t$ tests and proteins with log foldchange of \pm 1 (two folds in linier mode) and a $t$-test $p$-value of $<0.05$ were considered statistically significantly altered in abundances across the sample treatment conditions.

Figure 1. Workflow overview. A) Membrane-associated proteins extraction. B) Sample preparation for LCMS/MS and mass spectrometric measurements. C) Data analysis using Perseus software platform. 
Capítulo III

\section{II.4. Sample preparation for LC-MS/MS}

\section{In-Solution Digestion}

Equal amount $(100 \mu \mathrm{g})$ of each sample was reduced with $10 \mathrm{mM}$ DTT at $60^{\circ} \mathrm{C}$ for $30 \mathrm{~min}$, followed by alkylation with $20 \mathrm{mM}$ IAA for $30 \mathrm{~min}$ at room temperature and lastly quenched with 5mM DTT for 15 minutes at room temperature. Subsequently, proteins were proteolytically digested using trypsin ( $1 \mu \mathrm{g}$, Sigma; protein versus trypsin ratio: $50 / 1)$ and incubated at $37^{\circ} \mathrm{C}$ overnight (Figure $1 \mathrm{~B}$ ).

\section{Mass spectrometric measurements}

Nanoflow LC-MS/MS was performed by coupling a Dionex Ultimate 3000 nRSLC nanoliquid chromatography system with Q-Exactive-HF-X mass spectrometer (both from Thermo Fisher Scientific). Proteolytic peptides were separated using an in-house packed C18 reverse-phase precolumn (Halo-C18, length $3.5 \mathrm{~cm}$, inner diameter $100 \mu \mathrm{m}$, particle diameter $2.7 \mu \mathrm{m}$ ) in-line with an in-house packed C18 reverse-phase analytical column (Halo-C18, length $15 \mathrm{~cm}$, inner diameter $75 \mu \mathrm{m}$, particle diameter $2.7 \mu \mathrm{m})$. Peptides were eluted with a 130 min gradient increasing from 2 to $30 \% \mathrm{ACN}$ in $\mathrm{ddH}_{2} \mathrm{O}$ with $0.1 \%$ formic acid at flow rate of $300 \mathrm{~nL} / \mathrm{min}$ and electrosprayed into a Q-Exactive-HF-X mass spectrometer.

A $2.6 \mathrm{kV}$ electrospray voltage was applied via a liquid junction upstream of the column. Peptide precursors from 350 to $1400 \mathrm{~m} / \mathrm{z}$ were scanned at $60 \mathrm{k}$ resolution with an AGC target value of $3 \times 10^{6}$. The 20 most intense ions from the preceding survey scan were fragmented by Higher-Energy Collisional Dissociation (HCD) using normalized collision energy of 28 with an isolation width of $1.3 \mathrm{~m} / \mathrm{z}$. Only precursors with charge state of +2 to +6 were subjected to MS/MS analysis. The MS method had a minimum signal required value of $4 \times 10^{3}$ for MS2 triggering, an AGC target value of $2 \times 10^{5}$ for MS2 and a maximum injection time of $60 \mathrm{~ms}$ for MS2. MS/MS scan resolution was set at $15 \mathrm{k}$. The dynamic exclusion was set to 90 seconds. A blank injections were run following every sample injection to reduce carryover proteins.

\section{II.5 Proteomics data analysis}

The LC-MS/MS spectra obtained from the proteomics experiment was identified and quantified using SEQUEST algorithm in Proteome Discoverer v2.2 (Thermo Fisher Scientific). The peptides were mapped against the annotated T. reesei in silico proteome (download date: 13.11.2017) obtained from the JGI database 
Capítulo III

(https://genome.jgi.doe.gov/Trire2/Trire2.home.html). Prior to the main search, off-line recalibration of mass accuracy was performed by spectral recalibration node. In the database search, up to two missed cleavage were allowed and cysteine carbamidomethylation of was set static modification. Precursor and fragment mass tolerance was $10 \mathrm{ppm}$ and $0.02 \mathrm{Da}$ respectively. Oxidation $(\mathrm{M})$, deamination $(\mathrm{N}$ and $\mathrm{Q})$, Gln->pyro-Glu (Q, peptide-terminus), acetylation of $\mathrm{NH}_{2}$-terminal methionine, acetylation of $\mathrm{NH}_{2}$-terminus with methionine loss (Protein N-terminus), were selected as dynamic modifications. False discovery rate (FDR) calculated by Percolator (an FDR of $1 \%$ was used) based on reverse sequence database searches. For label free MS1 quantification, the chromatographic peaks were detected using Minora feature detector algorithm (Thermo Fisher Scientific) with default settings.

Identified MS/MS spectra were consolidated in the consensus workflow. The feature mapper node was used to map features across multiple files with 15 min maximum retention time shift, 6-ppm mass tolerance, and a minimum signal to noise threshold of 4 . Peptides with following modifications including deamination (N, Q), Gln->pyro-Glu (Q, peptide Nterminus), acetylation of NH2 -terminus with methionine loss (Protein N-terminus) were excluded from protein quantification. For further analysis, protein area values were exported into an Excel sheet.

Protein abundance values were further analyzed using Perseus software platform. Data were $\log$ transformed and normalized to the median quantitative value of the respective sample. Only proteins present in at least two biological replicates and were considered for further analysis and the missing values were imputed using function in Perseus (https://www.nature.com/articles/nmeth.3901) which uses the imputation function based on normal distribution pattern of abundances in the samples. Subsequently protein quantities across respective conditions were compared using $t$-tests and proteins with log fold-change of \pm 1 (two folds in linier mode) and a $t$-test $p$-value of $<0.05$ were considered statistically significantly altered in abundances across the sample treatment conditions.

\section{II.6 Prediction of membrane proteins}

Transmembrane domains were predicted by TMHMM (KROGH et al., 2001) using the TMHMM Server, v. 2.0, and the Gravy values (KYTE et al., 1982) were predicted using the Sequence Manipulation Suite: Protein GRAVY (http://www.bioinformatics.org/sms2/protein_gravy.html). 


\section{7 Phylogenetic tree}

The sequence of proteins of $T$. reesei and other species used for the construction of the phylogenetic tree were obtained from the JGI Genome Portal. The multiple protein sequence alignment was performed using the ClustalW and the tree neighbour-joining type (reference). After this, the phylogenetic tree was constructed using the iTOL: Interactive Tree Of Life software (https://itol.embl.de/).

\section{Results}

\section{III.1 Qualitative Analysis of Experimental Data}

Most of the protocols of membrane proteome purification involves a step of discontinuous sucrose density gradient, prepared by layering successive solutions, with decreasing sucrose concentrations. However, studies on Aspergillus niger and Trichoderma reesei membrane proteome purification revealed sucrose density gradient had no significant role in enriching plasma membrane proteome (SLOOTHAAK et al., 2015, 2016a, 2016b) . In this connection, in our study $T$. reesei mycelium were lysed and proteins were subjected to two steps of centrifugation followed by one-step of ultracentrifugation $(\sim 85,000 \mathrm{~g})$, without density gradient erichment. The final fraction obtained was employed for analysis of plasmalemma proteins that were further processed for proteomic analysis.

In this study, T. reesei QM9414 was grown in two different carbon sources; cellulose and glycerol, and different time intervals; 6, 24 and 48 hours for cellulose samples and 24 hours for glycerol samples. The results showed that the overall ratio distributions are similar for all samples, presenting a normal distribution, (Additional file 1) and a positive correlation between the samples (Additional file 2). Besides that, the Principal Component Analysis (PCA) that attributes the largest variance to the difference between the different samples illustrates that the four sample groups were perfectly separated and easily distinguished (Additional file 3).

The qualitative analysis of the results obtained showed that the samples present good reliability and the data was considered satisfactory for further analysis. 
III.2 Global profile of the number of proteins with transmembrane helices identified during culture of Trichoderma reesei in the presence of cellulose and glycerol

Understanding the transportome of T.reesei is crucial to accomplish significant advancements at strain and process design levels. Wherefore, this work pretended to probing the membrane-associated proteome of $T$. reesei during the culture of cellulose in different time intervals to investigate how changing conditions in the presence of hydrolysates of cellulose can interfere with the profile of known and novel sugar transporters in the plasmalemma.

For this purpose, T. reesei QM9414 was grown in two different carbon sources; cellulose and glycerol, and for different time intervals; 6, 24 and 48 hours for in cellulose and 24 hours in glycerol as described (see Methods). Mass spectrometry profiling of T. reesei in cellulose cultures generated 1616 proteins in 6 hours, 1362 in 24 hours and 1097 in 48 hours sample groups. Similarly, in glycerol 24 hours culture, 1778 proteins were identified (Table 1; Figure 2A).

Transporters proteins, as an integral part of the membrane, must contain at least one protein domain that is thermodynamically stable in the hydrophobic portion of the plasmalemma. In eukaryotes, these are typically $\alpha$-helical structures(QUISTGAARD et al., 2016; SLOOTHAAK et al., 2015). To identify the proteins with predicted transmembrane helices (TMHs), a bioinformatics tool THMHH was employed. In the presence of cellulose, the number of proteins identified with at least one TMHs were 475, 409, and 313 in 6 hours, 24 hours and 48 hours cultures respectively (Table 1, Figure 2A). 
Table 1. Number of proteins identified in each sample

\begin{tabular}{|c|c|c|c|}
\hline Sample & $\begin{array}{l}\text { Number of proteins with } \\
\text { Transmembrane domains }\end{array}$ & Other proteins & $\begin{array}{l}\text { Total proteins } \\
\text { identified }\end{array}$ \\
\hline $\begin{array}{l}\text { QM9414 } \\
\text { cellulose } 6 \mathrm{~h}\end{array}$ & 475 & 1141 & 1616 \\
\hline $\begin{array}{l}\text { QM9414 } \\
\text { cellulose 24h }\end{array}$ & 409 & 953 & 1362 \\
\hline $\begin{array}{c}\text { QM9414 } \\
\text { cellulose } 48 \mathrm{~h}\end{array}$ & 313 & 784 & 1097 \\
\hline $\begin{array}{l}\text { QM9414 } \\
\text { Glycerol }\end{array}$ & 528 & 1250 & 1778 \\
\hline
\end{tabular}

Among all the proteins with TMHs domains present in the four sample groups analysed, more than half of the proteins were predicted to have between one and four transmembrane segments (Figure $2 \mathrm{~B}$ ) and 218 proteins are predicted to have more than five transmembrane segments. The analysis of the TMHs also showed that 228 proteins are predicted to have only one transmembrane segment.

The grand average hydropathy (GRAVY) score was used to determine the hydrophobicity of the identified proteins. In all four sample groups analyzed, 1751 proteins had negative GRAVY values and 309 proteins had positive values; indication of greater hydrophobicity. During the analysis, the proteins with predicted TMHs and no predicted TMHs (other proteins) were separately classified and the GRAVY values scores for these two classes of proteins are shown in figures $2 \mathrm{C}$ and $2 \mathrm{D}$. 


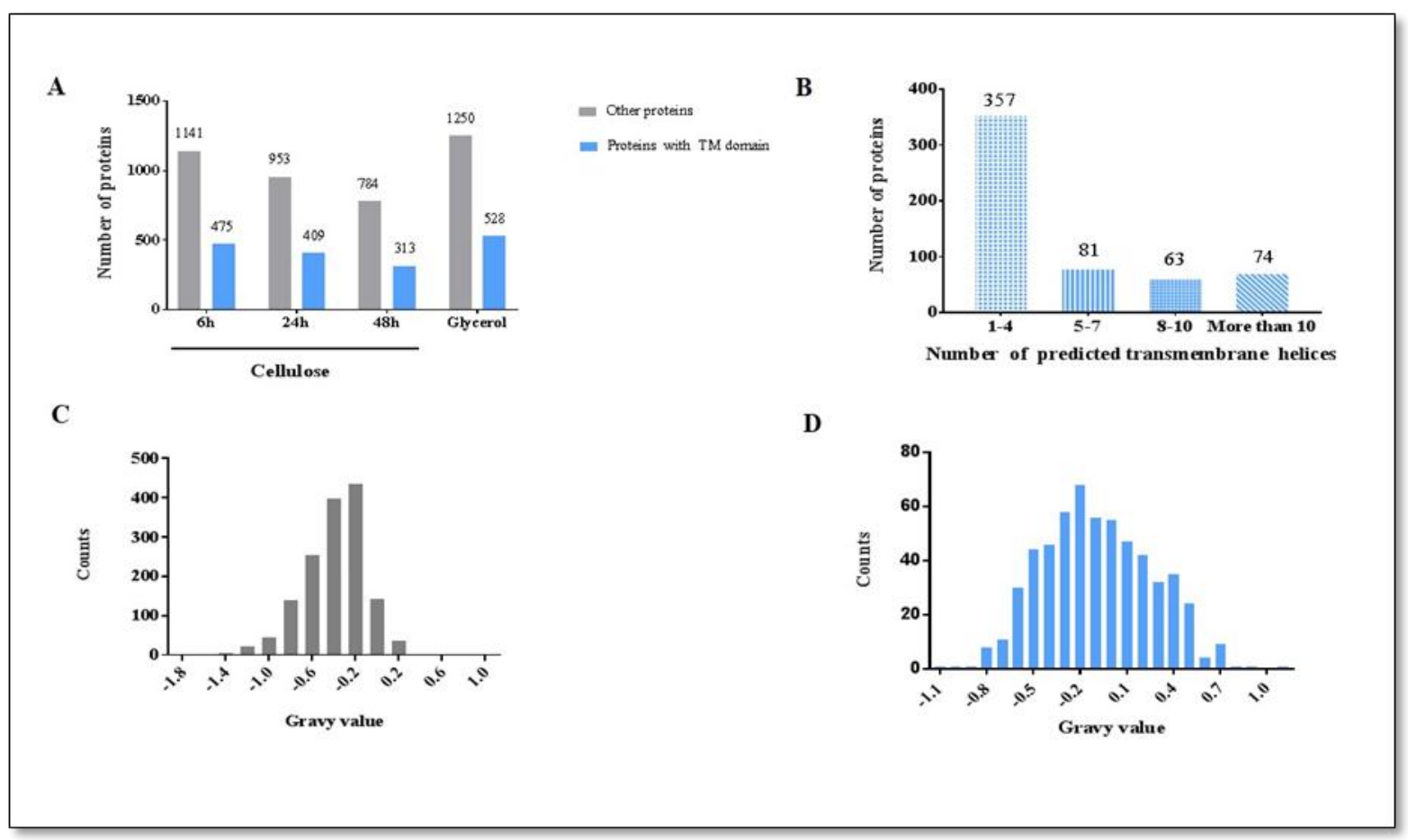

Figure 2. Global profile of the number of proteins identified in Trichoderma reesei grown in two different carbon sources and three different time intervals. A) Number of proteins identified with TM domains in blue and proteins with no TM domain (other proteins) in grey. B) Number of proteins with predicted transmembrane helices. C) Gravy value of proteins with no TM domain. D) Gravy value of proteins with TM domain.

\section{III.3 The $T$. reesei membrane-associated proteome in response to different carbon sources and time intervals}

A further analysis of the proteins with predicted TMHs during the culture of T. reesei in cellulose and glycerol showed (Figure 3A) that 454 proteins are present in both conditions, 61 proteins are exclusive to glycerol condition and 38 proteins are exclusive to cellulose condition. Among the 13 proteins exclusive to cellulose 6 hours condition, were identified glycosyl transferases, Major Facilitator Superfamily (MFS) transporters, protein required for sporulation (ID 62467) and proteins with no description (unknown proteins). In cellulose 24 hours condition, was identified a Zn2Cys6 transcriptional regulator (ID 106009) exclusive to this condition. In cellulose 48 hours, 14 proteins were exclusive to this condition, including MFS transporters, amino acid transporters and cation transporting ATPase.

As shown in Fig. 3B, gene ontology (GO) annotations suggest a different profile of number of proteins with molecular function, cellular component and biological process identified in each condition. Notably, a high number of predicted membrane proteins do not have a GO-annotation. 
The Eukaryotic Orthologous Groups (KOG) classification analysis of the proteins identified (Figure 3C) suggest that at least a third of the proteins with TMHs are involved in transport and metabolism, sensing or signaling. Within these groups are pumps and channels for diverse solutes, peptides and proteins; GPCRs and associated factors; and proteins with catalytic activity such as glycosyl transferases. Besides that, many proteins have more than one putative function, showing a general function prediction; this class also contains a number of transporters proteins.

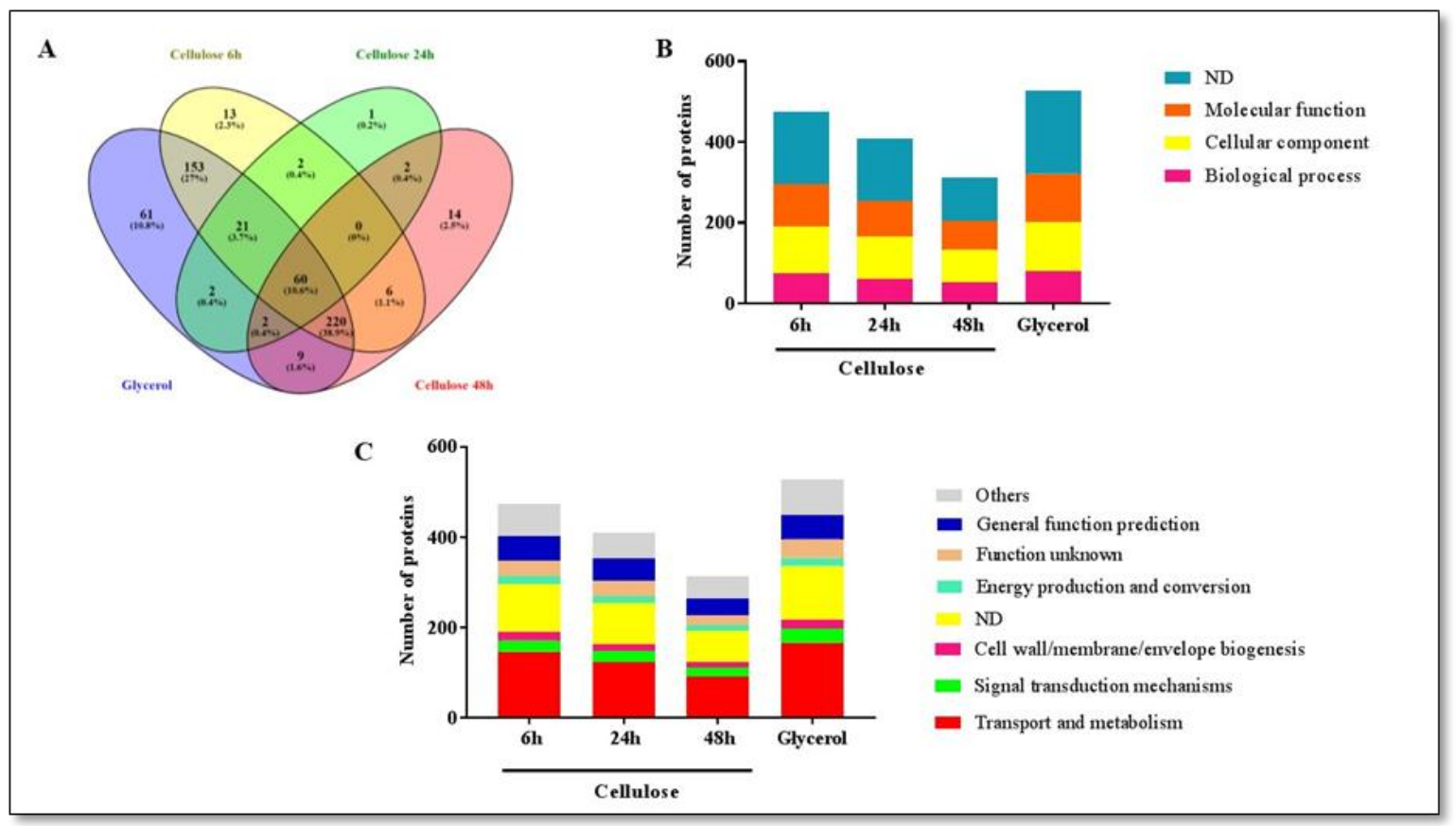

Figure 3. A) Venn diagram depicting the proteins with predicted TMHs in T. reesei during 6, 24 and 48 hours cultures in cellulose and glycerol (24 hours). B) Gene ontology (GO) annotations of the identified proteins with predicted TMHs. C) Eukaryotic Orthologous Groups (KOG) classification analysis of the identified proteins with predicted TMHs.

A deeper analysis of the proteins classified (KOG) in general function, and transport and metabolism (Figure 4), unveiled the presence of two most intensively studied families of transporter proteins; 18 proteins belonging to $\mathrm{ABC}$ (ATP binding cassette) transporters family and 22 proteins belonging to Major Facilitator Superfamily (MFS). 


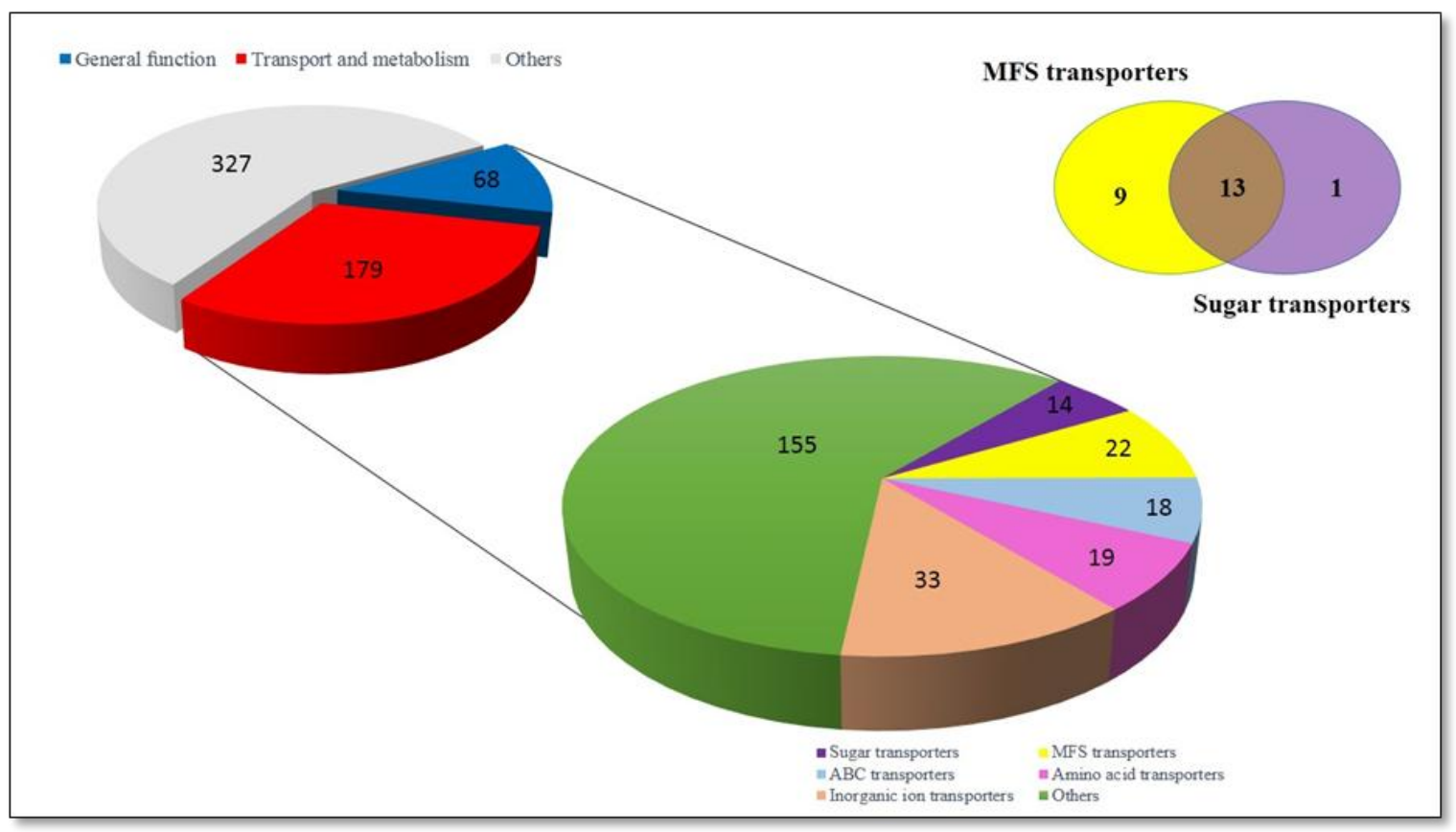

Figure 4. A deep analysis in the proteins classified (KOG) in general function, and transport and metabolism to identify transporters proteins.

The MFS is divided into 17 distinct families within which three families $(1,5$, and 7$)$ participate in sugar transport into the cell. These transporters carried out the transport of carbon sources, including hexose and pentose sugars, and small soluble molecules in response to ion gradients (QUISTGAARD et al., 2016). Among the 22 MFS proteins identified, 13 of them are classified as sugar transporters. In this study, 14 sugar transporters were identified in T. reesei during culture of cellulose and glycerol.

\section{III.4 Potential sugar transporters involved during the biomass degradation process}

In the recent years, a few studies have been contributing to identify new sugar transporters in T. reesei using transcriptome and proteomics analysis (BISCHOF et al., 2013; BORIN et al., 2017; NOGUEIRA et al., 2018; RIES et al., 2013b). However, little research has been conducted to examine the contribution of sugar transporters during the biomass degradation in T.reesei.

In this study, 14 sugar transporters proteins were identified (classified according to functional annotation in the JGI Genome Portal) in the cultures of $T$. reesei in presence of glycerol and cellulose as a single carbon source. In the table 2 we can find the IDs of the sugar transporters identified, the number of TMHs, gravy values, the total number of distinct peptide sequences identified in the protein group and the number of peptide spectrum matches 
(PSMs). The number of PSM's is the total number of identified peptide spectra matched for the protein. The PSM value for the identified proteins were higher than the number of peptides identified showing a high-scoring proteins.

Table 2. Sugar transporters identified by LC/MS analysis during culture of T. reesei in presence of cellulose and glycerol.

\begin{tabular}{|c|c|c|c|c|}
\hline ID & $\begin{array}{c}\text { NUMBER } \\
\text { OF } \\
\text { THMS }\end{array}$ & $\begin{array}{l}\text { GRAVY } \\
\text { VALUE }\end{array}$ & PEPTIDES & PSMS \\
\hline 50618 & 10 & 0.157098 & 18 & 213 \\
\hline 47710 & 12 & 0.379964 & 11 & 149 \\
\hline 68812 & 11 & 0.236731 & 12 & 222 \\
\hline 65153 & 10 & 0.388288 & 9 & 48 \\
\hline 3405 & 12 & 0.359332 & 4 & 35 \\
\hline 22912 & 11 & 0.214964 & 5 & 20 \\
\hline 53903 & 12 & 0.391257 & 2 & 5 \\
\hline 123809 & 12 & 0.704024 & 2 & 10 \\
\hline 121850 & 9 & 0.253417 & 2 & 4 \\
\hline 80875 & 12 & 0.455268 & 7 & 39 \\
\hline 50894 & 11 & 0.423633 & 5 & 30 \\
\hline 123702 & 10 & 0.420921 & 6 & 64 \\
\hline 44175 & 10 & 0.239271 & 10 & 119 \\
\hline 76800 & 12 & 0.319444 & 9 & 111 \\
\hline
\end{tabular}


Among the sugar transporters identified, four of them (ID 50894, ID 3405, ID 47710 and ID 22912) have been already characterized in $T$. reesei. The two major facilitator superfamily (MFS) sugar transporters, Stp1 (ID47710) and Crt1(ID 3405), were implicated in cellulose sensing and cellulase induction in T. reesei (ZHANG et al., 2013). The crt1 (ID $3405)$, is required for cellulase induction by cellulose and lactose, as well as mediates the cellulose sensing process in T. reesei (ZHANG et al., 2013); Hxt1, is a glucose permease (ID 22912) (ZHANG et al., 2015), and Str1 ( ID 50894), an essential transporter for pentose utilization in T. reesei (HUANG et al., 2015).

The results demonstrated that although 12 sugar transporters identified were present in all the conditions analyzed (Figure 5A), the abundance data showed a differential profile during 6, 24 and 48 hours of culture in cellulose. In presence of glycerol, 10 sugar transporters were down regulated and up regulated in presence of cellulose (Figure 5B).

Interestingly, the STP1(ID 47710) transporter is up regulated during 6 hours of culture and down regulated during the 24 hours of culture in presence of cellulose. Unlike this, the Ctr1 transporter (ID 3405) is down regulated during 6 hours of culture and up regulated during the 24 and 48 hours of culture in presence of cellulose (Figure 5B).

Five (ID 53903, ID 123809, ID 121850, ID 80875, ID 44175) other putative MFS sugar transporters were up regulated during 6 hours of culture. Among this, one (ID 121850) of them was up regulated in presence of cellulose and down regulated in presence of glycerol (Figure 5B), being an interesting transporter to be studied. This transporter may be involved with the cellulose sensing in $T$. reesei. 


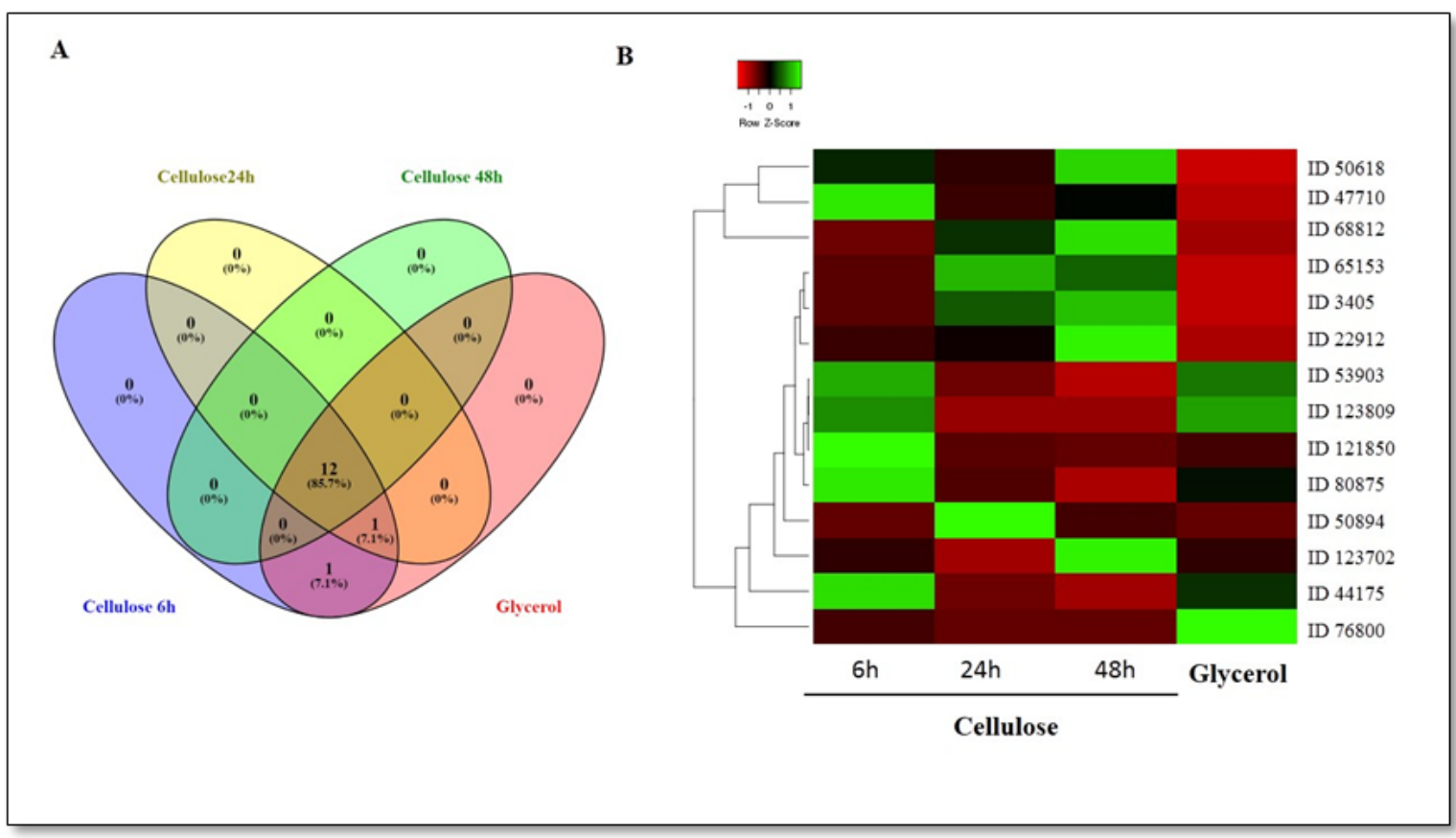

Figure 5. A) Venn diagram showing the number of sugar transporters identified and present in each sample. B) Heat map of the abundance of the sugar transporters identified.

Furthermore, the protein abundance values showed that the Str1 transporter (ID 50894 ) is up regulated only in presence of cellulose during 24 hours and down regulated in presence of glycerol. Also, the transporter ID 123702 is up regulated only in presence of cellulose during 48 hours and down regulated in presence of glycerol.

The MFS permease ID 76800 was up regulated in presence of glycerol and down regulated in presence of cellulose. In Trichoderma this permease is target of light signaling (DOS SANTOS CASTRO et al., 2014).

Phylogenetic analysis of the transporters identified with other fungal transporters indicated that these transporters show homology with disaccharide and monosaccharide transporters (Figure 6). 


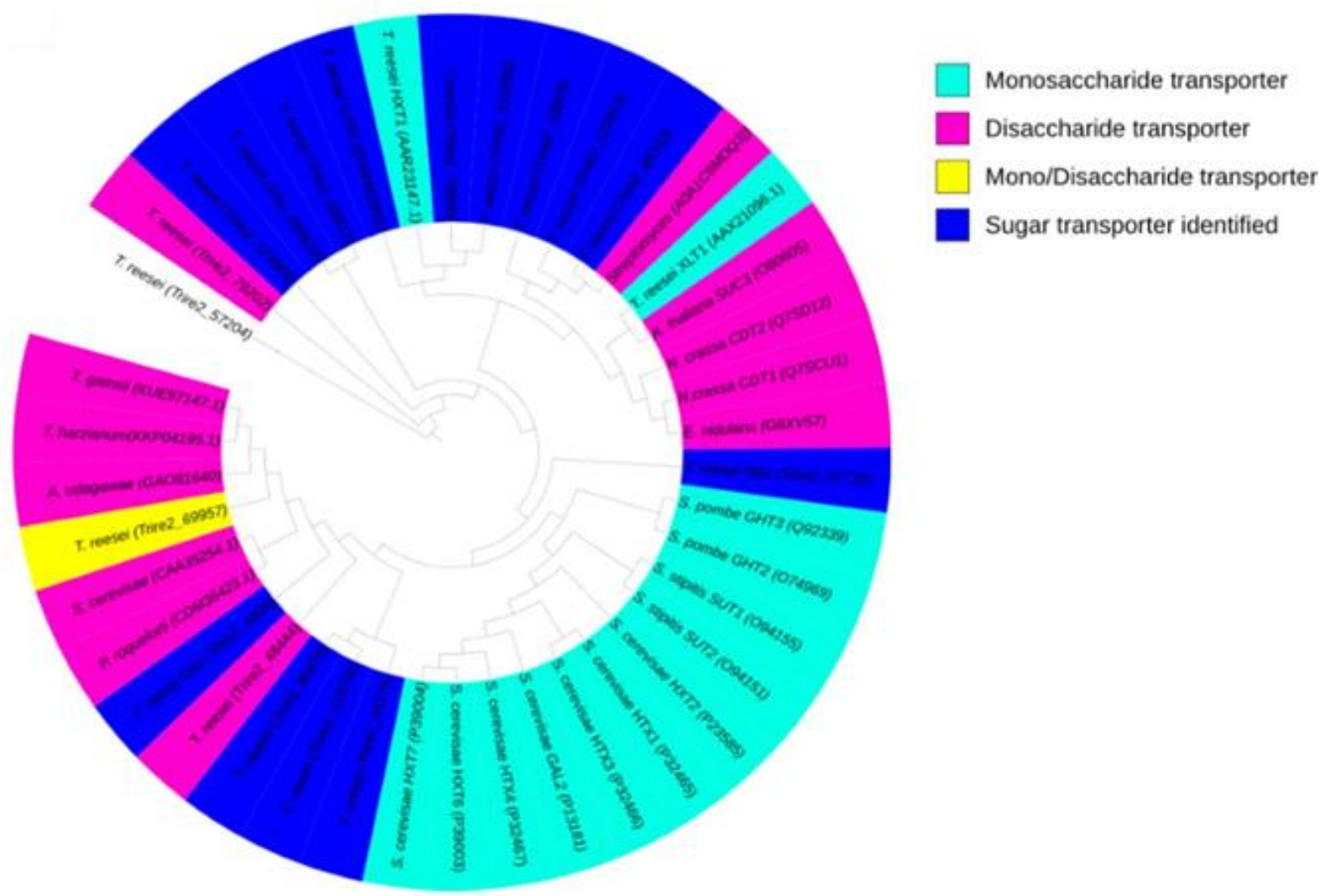

Figure 6. Phylogenetic analysis of the sugar transporters identified. The multiple alignment was performed using the ClustalW and the tree neighbour-joining type. The phylogenetic tree was constructed using the iTOL: Interactive Tree Of Life software.

In this data we found 9 (ID 50618, ID 68812, ID 65153, ID 53913, ID 123809, ID 121850, ID80875, ID123702 and ID44175) uncharacterized sugar transporters in T. reesei and up regulated in presence of cellulose. The identification of these sugar transporters is an important step to discover novel components potentially involved during the process of cellulose degradation. The functional characterization of these transporters will aid in better understanding of the influence of these transporters in the expression and secretion of CAZymes and, consequently, in the biomass degradation.

\section{Discussion}

Several studies showed evidences that the soluble oligosaccharides released from cellulose or their derivatives may well function as the actual molecules that trigger cellulase induction (MANDELS; REESE, 1959; STERNBERG; MANDELS, 1979b). With this, the uptake of soluble oligosaccharides derived from cellulose hydrolysis represents a potential point of control in the induced cascade. 
During the culturing of $T$. reesei in presence of cellulose in different conditions $(6,24$ and 48 hours), we considered that, over time, distinct sugars as mono and disaccharides (as glucose, sophorose, cellobiose and cellotriose) are present in the culture medium and diverse signaling process it's running into the fungal cell. Therefore, a temporal analyses will allow the understanding about the importance of each sugar transporter in each time interval and the influence of these in the transport system network and in cellulase induction during the cellulose degradation process.

In the figure 7 we can see all the 13 sugar transporters up regulated in presence of cellulose, nine of them being uncharacterized. The real role of these uncharacterized sugar transporters during the cellulose deconstruction process is yet to be explored.

Four sugar transporters identified in this study have been already characterized in $T$. reesei. HXT1 is described as a glucose permease. Glucose is an ending product of cellulose degradation process. Curiously, the HXT1 shown more abundance into the cell only after 24 hours of the fungi cultive in presence of cellulose. After 24 hours of culture, the entrance of this sugar into the cell, can repress the expression of cellulases encoding genes.

The T. reesei STP1 (ID 47710) transporter, also identified in this work, is involved in glucose and cellobiose uptake (ZHANG et al., 2013). The results showed that during 6 hours of fungi culture, this transporter was high regulated. During this period, the transport of cellobiose into the cell can promote the induction of cellulose enconding genes, providing the cellulolytic machinery to cellulose deconstruction .

Besides that, T. reesei Crt1 (ID3504) was up regulated in presence of cellulose during 24 and 48 hours of culture. This transporter mediates the cellulolytic signaling independent of sugar transporting activity. It is essential for fungi growth and enzymatic activity on cellulose or lactose, however the uptake of cellobiose or sophorose by T. reesei was not impaired in the absence of Ctr1 gene encoding (ZHANG et al., 2013).

Another sugar transporter identified in this work, Str1 (ID 50894), is known to be involved with pentoses uptake and is also involved in the induction of xylanase expression in T. reesei (HUANG et al., 2015). This sugar transporter was up regulated in presence of cellulose during 24 hours of culture. RNA-seq data analysis also showed that this sugar transporter was up regulated during culture of $T$. reesei in presence of cellulose, glucose or sugarcane bagasse (DOS SANTOS CASTRO et al., 2014; PAULA et al., 2018). Besides being involved with pentoses uptake, this sugar transport might be also involved during the process of cellulose degradation in $T$. reesei. 
Some sugars when transported into the cell by protein transporters act as repressor (as glucose) (CAMPOS ANTONIÊTO et al., 2016) or inductor (as cellobiose)(MANDELS; REESE, 1959) of cellulase genes. Also, some transporters act as receptors, or transceptors, to sense and respond to the $T$. reesei environments in presence of cellulose(ZHANG et al., 2013). During this process, transcription factors, positive or negative regulators, can regulate the expression of sugar transporters that are responsible for sugar uptake in response to different carbon sources, and regulate CAZymes as well (ANTONIÊTO et al., 2014; DOS SANTOS CASTRO et al., 2016).

In this work, we identified novel players in biomass degradation and further studies to verify their role during this process will be essential to understanding the transport system network in $T$. reesei, how this novel transporters identified can affect the cellulase encoding genes and consequently affect the biomassa degradadion process. With this, we can describe potential transporters for biotechnology and strain engineering.

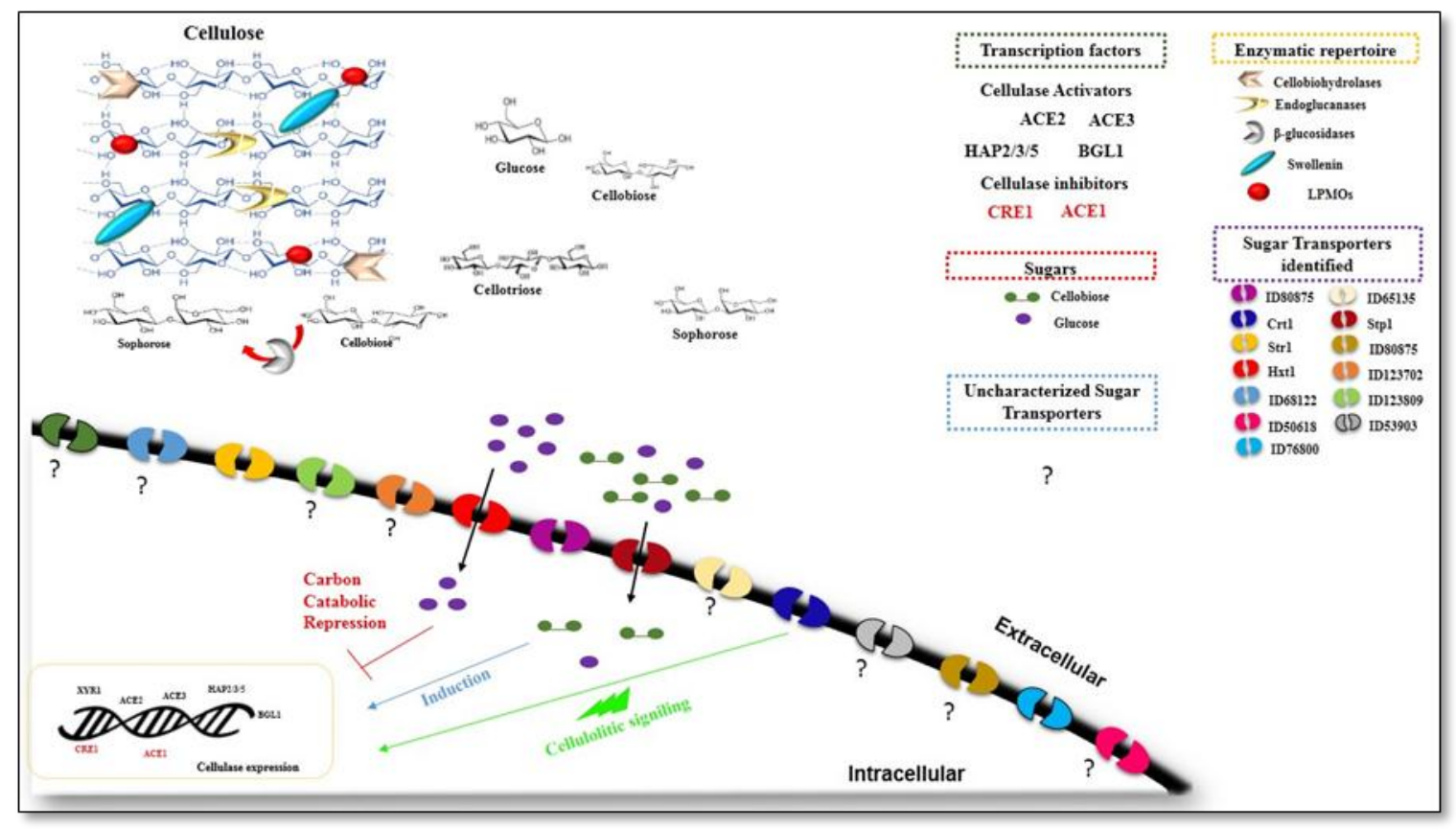

Figure 7. Model of sugar transporters-mediated cellulase induction in T. reesei. The figure shows the potential mechanism of signaling mediated by known sugar transporters under the control of cellulase expression. Besides that, this scheme shows all the sugar transporters identified in this study, including the uncharacterized one (?). This scheme also shows the processes involved in regulating lignocellulosic enzymes in T. reesei. The major enzymes involved in mobilization of lignocellulosic material are endoglucanases (EGs), cellobiohydrolases (CBHs), and $\beta$-glucosidases. These enzymes act synergistically to break down biomass. Accessory enzymes such as swollenins and Lytic Polysaccharide Monooxygenases (LPMOs) are also important in this process. The expression of all the degrading enzymes is controlled by the major transcription factors (TFs): XYR1, ACE1, ACE2, ACE3, BGL1, CRE1, and the HAP2/3/5 complex. 


\section{Conclusion}

Understanding the involvement of sugar transporters during the biomass degradation process is essential to develop new technologies that aim at optimization of bioethanol production. In this work, we identified 9 uncharacterized sugar transporters that can be an important component during the cellulose deconstruction. Further studies will be performed to better understand the role of these transporters during this process to allow a future strain engineering.

\section{References}

ANTONIÊTO, A. C. C. et al. Defining the genome-wide role of CRE1 during carbon catabolite repression in Trichoderma reesei using RNA-Seq analysis. Fungal Genetics and Biology, v. 73, p. 93-103, 2014.

BISCHOF, R. et al. Comparative analysis of the Trichoderma reesei transcriptome during growth on the cellulase inducing substrates wheat straw and lactose. Biotechnology for biofuels, v. 6, p. 127, 2013.

BISCHOF, R. H.; RAMONI, J.; SEIBOTH, B. Cellulases and beyond: The first 70 years of the enzyme producer Trichoderma reesei. Microbial Cell Factories, v. 15, n. 1, p. 1-13, 2016.

BORIN, G. P. et al. Comparative transcriptome analysis reveals different strategies for degradation of steam-exploded sugarcane bagasse by Aspergillus niger and Trichoderma reesei. BMC Genomics, v. 18, n. 1, p. 1-21, 2017.

CAI, P. et al. Evidence of a critical role for cellodextrin transporte 2 (CDT-2) in both cellulose and hemicellulose degradation and utilization in Neurospora crassa. PLoS ONE, v. 9, n. 2, 2014.

CAMPOS ANTONIÊTO, A. C. et al. Trichoderma reesei CRE1-mediated Carbon Catabolite Repression in Response to Sophorose Through RNA Sequencing Analysis. Current Genomics, v. 17, n. 2, p. 119-131, 2016.

CARRERAS-VILLASENOR, N.; SANCHEZ-ARREGUIN, J. A.; HERRERA-ESTRELLA, A. H. Trichoderma: sensing the environment for survival and dispersalMicrobiology, 2012.

CASTRO, L. D. S. et al. Expression pattern of cellulolytic and xylanolytic genes regulated by transcriptional factors XYR1 and CRE1 are affected by carbon source in Trichoderma reesei. Gene Expression Patterns, v. 14, n. 2, p. 88-95, 2014.

CHAUDHARY, N. et al. Proteome scale census of major facilitator superfamily transporters in Trichoderma reesei using protein sequence and structure based classification enhanced ranking. Gene, v. 585, n. 1, p. 166-176, 2016.

DOS REIS, T. F. et al. Identification and characterization of putative xylose and cellobiose transporters in Aspergillus nidulans. Biotechnology for Biofuels, v. 9, n. 1, p. 204, 2016.

DOS SANTOS CASTRO, L. et al. Comparative metabolism of cellulose, sophorose and 
Capítulo III

glucose in Trichoderma reesei using high-throughput genomic and proteomic analyses. Biotechnology for biofuels, v. 7, n. 1, p. 41, 2014.

DOS SANTOS CASTRO, L. et al. Understanding the Role of the Master Regulator XYR1 in Trichoderma reesei by Global Transcriptional Analysis. Frontiers in Microbiology, v. 7, n. February, p. 1-16, 2016.

FURUKAWA, T. et al. Identification of specific binding sites for XYR1, a transcriptional activator of cellulolytic and xylanolytic genes in Trichoderma reesei. Fungal Genetics and Biology, v. 46, n. 8, p. 564-574, 2009.

GLASS, N. L. et al. Plant cell wall deconstruction by ascomycete fungi. Annual review of microbiology, v. 67, p. 477-98, 2013.

HÄKKINEN, M. et al. Re-annotation of the CAZy genes of Trichoderma reesei and transcription in the presence of lignocellulosic substrates. Microbial cell factories, v. 11, p. 134, jan. 2012.

HUANG, Z. et al. A novel major facilitator transporter TrSTR1 is essential for pentose utilization and involved in xylanase induction in Trichoderma reesei. Biochemical and Biophysical Research Communications, v. 3045, p. 1-7, 2015.

IVANOVA, C. et al. Systems Analysis of Lactose Metabolism in Trichoderma reesei Identifies a Lactose Permease That Is Essential for Cellulase Induction. PLoS ONE, v. 8, 2013.

KROGH, A. et al. Predicting Transmembrane Protein Topology with a Hidden Markov Model : Application to Complete Genomes. 2001.

KYTE, J. et al. A Simple Method for Displaying the Hydropathic Character of a Protein. p. 105-132, 1982.

MANDELS, M.; REESE, E. T. INDUCTION OF CELLULASE IN FUNGI BY CELLOBIOSE. n. Cx, p. 816-826, 1959.

NAKARI-SETÄLÄ, T. et al. Genetic modification of carbon catabolite repression in Trichoderma reesei for improved protein production. Applied and Environmental Microbiology, v. 75, n. 14, p. 4853-4860, 2009.

NOGUEIRA, K. M. V et al. Biotechnology for Biofuels Characterization of a novel sugar transporter involved in sugarcane bagasse degradation in Trichoderma reesei. p. 1-17, 2018.

ORCIUNCULA, J. D. O. P. et al. Identification of Major Facilitator Transporters Involved in Cellulase Production during Lactose Culture of Trichoderma reesei PC-3-7. v. 77, n. 5, p. 1014-1022, 2013.

PAULA, R. G. DE et al. Review Article New Genomic Approaches to Enhance Biomass Degradation by the Industrial Fungus Trichoderma reesei. v. 2018, 2018.

PAUL DALY, JOLANDA M. VAN MUNSTER, R. R. AND D. B. A. No Title. In: SILVA, R. N. (Ed.). . Fungal Biothecnology for Biofuel Production. [s.l: s.n.]. p. 82-127.

QUISTGAARD, E. M. et al. Understanding transport by the major facilitator superfamily (MFS): structures pave the way. Nature Reviews Molecular Cell Biology, v. 17, n. 2, p. 123-132, 2016. 
REIS, T. F. DOS et al. Identification of glucose transporters in aspergillus nidulans. PLoS ONE, v. 8, n. 11, p. 1-15, 2013.

RIES, L. et al. Genome-wide transcriptional response of Trichoderma reesei to lignocellulose using RNA sequencing and comparison with Aspergillus niger. p. 1-12, 2013.

SAINI, J. K.; SAINI, R.; TEWARI, L. Lignocellulosic agriculture wastes as biomass feedstocks for second-generation bioethanol production: concepts and recent developments. 3 Biotech, v. 5, n. 4, p. 337-353, 2015.

SCHMOLL, M. et al. The G-alpha protein GNA3 of Hypocrea jecorina (anamorph Trichoderma reesei) regulates cellulase gene expression in the presence of light. Eukaryotic Cell, v. 8, n. 3, p. 410-420, 2009.

SEIBOTH, B.; IVANOVA, C.; SEIDL-SEIBOTH, V. Trichoderma reesei: A Fungal Enzyme Producer for Cellulosic Biofuels. Biofuel Production-Recent Developments and Prospects, 2011.

SLOOTHAAK, J. et al. Aspergillus niger membrane-associated proteome analysis for the identification of glucose transporters. Biotechnology for biofuels, v. 8, p. 150, 2015.

SLOOTHAAK, J. et al. Biotechnology for Biofuels Identification and functional characterization of novel xylose transporters from the cell factories Aspergillus niger and Trichoderma reesei. Biotechnology for biofuels, v. 9, n. 148, p. 1-15, $2016 \mathrm{a}$.

SLOOTHAAK, J. et al. Identification of a Novel L-rhamnose Uptake Transporter in the Filamentous Fungus Aspergillus niger. PLoS Genetics, v. 12, n. 12, p. 1-27, 2016b.

STERNBERG, D.; MANDELS, G. R. Induction of Cellulolytic Enzymes in Trichoderma reesei by Sophorose. v. 139, n. 3, p. 761-769, 1979.

ZABED, H. et al. Bioethanol production from renewable sources: Current perspectives and technological progress. Renewable and Sustainable Energy Reviews, v. 71, n. October 2015, p. 1-27, 2017.

ZHANG, W. et al. Two Major Facilitator Superfamily Sugar Transporters from Trichoderma reesei and Their Roles in Induction of Cellulase. v. 288, n. 46, p. 32861-32872, 2013.

ZHANG, W. et al. Identification of residues important for substrate uptake in a glucose transporter from the filamentous fungus Trichoderma reesei. Scientific Reports, v. 5, n. 27, p. 1-10, 2015. 


\section{Considerações referente ao capítulo III}

No capítulo III foi relatado a identificação de 13 transportadores de açúcar positivamente regulados em presença de celulose, sendo que 4 destes transportadores identificados já foram descritos e caracterizados em T. reesei.

Através dos dados obtidos, foi possível fazer um mapeamento do sistema de transporte de açúcar no fungo do decorrer do processo de degradação da biomassa. Cada transportador de açúcar apresentou um perfil de expressão específicos diante da análise temporal realizada, o que pode ser reflexo da presença do substrato, proveniente do hidrolisado celulósico, no meio.

Com a futura caracterização dos transportadores de açúcar identificados, os substratos específicos desses transportadores poderão ser também mapeados e uma melhor compreensão do papel de cada transportador na célula durante o processo de degradação poderá ser alcançada.

Além disso, a identificação desses transportadores abrirá portas para futuros estudos que visam o engenheiramento de microrganismos com aplicação na produção de etanol $2 \mathrm{G}$. 


\section{Considerações finais}

Trichoderma reesei apresenta um versátil sistema de degradação de polissacarídeos, celulose e hemicelulose, que compõem a parede celular de plantas. Devido a sua capacidade de secretar grande quantidade de enzimas, é um dos maiores produtores de enzimas comerciais que podem ser utilizadas no processo de conversão do material lignocelulósico em etanol (BISCHOF; RAMONI; SEIBOTH, 2016).

A maquinaria enzimática produzida pelo fungo atua de maneira sinérgica e toda a rota regulatória, que envolve fatores de transcrição e moléculas repressoras (glicose) e indutoras (celulose, celobiose, soforose), e controlam a expressão de genes que codificam para estas enzimas, são bem descritos na literatura(SCHMOLL; KUBICEK, 2003).

No entanto, toda cascata de sinalização que envolve a presença de açúcares indutores ou repressores, bem como o sistema de transporte envolvido no processo de degradação da biomassa lignocelulósica, não está bem esclarecido.

Durante o processo de degradação da biomassa lignocelulósica por $T$. reesei, uma mistura de monómeros e dissacarídeos estarão naturalmente presentes no meio extracelular. Ao longo do tempo, à medida que o material de lignocelulose é degradado, os fungos são expostos a uma sucessão de condições variáveis (PAUL DALY, JOLANDA M. VAN MUNSTER, 2016).

As análises das respostas transcriptômicas e proteômicas globais de fungos a uma variedade de condições específicas de cultura são abordagens úteis para obter conhecimento sobre os elementos estruturais e regulatórios específicos necessários para a utilização de fontes específicas de carbono. Através destas análises, nessa tese nós identificamos novos transportadores de açúcar potencialmente envolvidos na degradação do bagaço de cana-deaçúcar e de celulose.

No capítulo II, em uma revisão dos principais resultados de pesquisa do nosso grupo, transportadores de açúcar diferencialmente expressos em variadas fontes de carbono foram identificados. Foi relatado que a expressão de genes que codificam para transportadores de açúcar é dependente da fonte de carbono na qual o fungo é exposto, sendo regulados por fatores de transcrição que modulam a expressão destes genes em presença de diferentes fontes de carbono. Além disso, o fator de transcrição XYR1, modula positivamente genes que codificam para transportadores de açúcar identificados durante cultivo de $T$. reesei em presença de celulose (DOS SANTOS CASTRO et al., 2016). Em contrapartida, CRE1 reprime a expressão de genes de transportadores de açúcar identificados durante o cultivo do fungo em presença de glicose (ANTONIÊTO et al., 2014). 
Considerações finais

No capítulo I, o transportador de açúcar Tr69957 de T. reesei, identificado através de análises de dados de RNA-seq descritas no capítulo II, foi caracterizado. Análises de validação funcional revelaram uma função do transportador no carreamento de xilose, manose e celobiose em T. reesei. Além disso, este transportador parece exercer importante função durante o processo de degradação do bagaço de cana-de-açúcar pelo fungo, considerando que a deleção gênica daquele afetou tanto a expressão de genes de celulases quanto de hemicelulases.

No capítulo II, os dados mostraram que Tr69957 foi especificamente induzido tanto em presença de celulose quanto bagaço de cana, no entanto, no capítulo III vimos que este mesmo transportador não foi identificado através de dados de proteômica durante o cultivo do fungo em presença de celulose.

Estes resultados sugerem que o transportador Tr69957, por estar envolvido tanto no transporte de açúcares proveniente da fração hemicelulósica, quanto celulósica, pode ser especificamente induzido em presença de bagaço de cana. Além disso, as análises de dados de RNA-seq realizadas no capítulo II desta tese, foram provenientes de experimentos nos quais o cultivo do fungo em presença de celulose ou bagaço de cana ocorreram em intervalos de tempo diferentes dos realizados no capítulo III. Ao decorrer do processo de degradação, que equivale aos específicos intervalos de tempo analisados em cada trabalho, diferentes açúcares estarão presentes no meio, regulando a expressão dos transportadores de açúcar.

No capítulo III, análises proteômicas permitiram a identificação de 14 transportadores de açúcar durante o cultivo do fungo em presença de celulose. Nove destes transportadores, ainda não foram caracterizados e, portanto, não apresentam uma função bem esclarecida no processo de degradação de celulose em T. reesei. A identificação dos transportadores de açúcar Ctr1 e STP1 descritas neste capítulo, corroboram com os dados da literatura que descrevem uma importante função destes transportadores durante processos de sinalização e absorção de açúcares em presença de celulose. Em adição, no capítulo II é descrita a identificação, por análises de dados de RNA-seq proveniente do cultivo do fungo em presença de celulose ou soforose, de três transportadores de açúcar (Ctr1, Hxt1 e STR1), também identificados através dos dados de proteômica descritos no capítulo III.

Os dados relatados nessa tese, apontam um papel essencial de transportadores de açúcar na utilização da biomassa lignocelulósica por $T$. reesei. Estas proteínas são responsáveis pelo carreamento de açúcares provenientes da degradação da lignocelulose do ambiente extracelular para o intracelular, que, ao serem transportados para o interior da 
célula, poderão atuar como moléculas reguladoras da expressão de CAZymes. Dessa forma, os transportadores podem afetar a degradação da lignocelulose através do transporte de moléculas que sinalizam mudanças na presença de substratos específicos e, consequentemente, influenciam a expressão de codificações de genes CAZymes. 
Conclusão

\section{Conclusão}

Nesta tese, nós utilizamos diferentes ferramentas para identificar e caracterizar transportadores de açúcar em $T$. reesei. Os dados apresentados, fornecem importantes informações a respeito do complexo sistema de transporte de açúcar do fungo. Além de relatar a influência destes transportadores no processo de degradação da biomassa por T. reesei, apresenta novos candidatos com potencial atuação na absorção de açúcares e sinalização celular durante a desconstrução do material lignocelulósico.

Com os dados apresentados, novos transportadores de açúcar poderão ser futuramente caracterizados. A manipulação genética de genes que codificam para estes transportadores, poderá originar linhagens de $T$. reesei mais potentes em relação à produção de celulases, ao mesmo tempo que poderá originar linhagens de $S$. cerevisiae com capacidade de absorção de diferentes açúcares provenientes da hidrólise da biomassa lignocelulósica. Diante desse contexto, o estudo de transportadores de açúcar representa um importante passo na busca por novas tecnologias que visam aprimorar a produção do etanol de segunda geração. 


\section{Perspectivas}

1) Analisar a especificidade dos transportadores de açúcar (identificados no capítulo III) frente a diferentes substratos através de análises de ancoragem molecular;

2) Após análises de ancoragem molecular, selecionar, pelo menos, três transportadores para realização de validação funcional em S. cerevisiae;

3) Inserção dos genes que codificam para o transportador Tr_69957 de Trichoderma reesei e uma $\beta$-glicosidase intracelular de Neurospora crassa em uma linhagem de $S$. cerevisiae (MEC 1133), engenheirada para metabolização de xilose e desenvolvida a partir da cepa $S$. cerevisiae PE-2 - amplamente utilizada nas usinas brasileiras produtoras de etanol. 


\section{Referências}

ANTONIÊTO, A. C. C. et al. Defining the genome-wide role of CRE1 during carbon catabolite repression in Trichoderma reesei using RNA-Seq analysis. Fungal Genetics and Biology, v. 73, p. 93-103, 2014.

APEL, A. R. et al. Evolved hexose transporter enhances xylose uptake and glucose / xylose co-utilization in Saccharomyces cerevisiae. Nature Publishing Group, n. September 2015, p. $1-10,2016$.

ATANASOVA, L. et al. Comparative transcriptomics reveals different strategies of Trichoderma mycoparasitism. BMC genomics, v. 14, n. 1, p. 121, 2013.

BISCHOF, R. et al. Comparative analysis of the Trichoderma reesei transcriptome during growth on the cellulase inducing substrates wheat straw and lactose. Biotechnology for biofuels, v. 6, p. 127, 2013.

BISCHOF, R. H.; RAMONI, J.; SEIBOTH, B. Cellulases and beyond: The first 70 years of the enzyme producer Trichoderma reesei. Microbial Cell Factories, v. 15, n. 1, p. 1-13, 2016.

BORIN, G. P. et al. Comparative secretome analysis of Trichoderma reesei and Aspergillus niger during growth on sugarcane biomass. PLoS ONE, v. 10, n. 6, p. 1-20, 2015.

BORIN, G. P. et al. Comparative transcriptome analysis reveals different strategies for degradation of steam-exploded sugarcane bagasse by Aspergillus niger and Trichoderma reesei. BMC Genomics, v. 18, n. 1, p. 1-21, 2017.

BRIENZO, M. Extração da hemicelulose do bagaço de cana-de-açúcar para produção de. 2010.

CAI, P. et al. Evidence of a critical role for cellodextrin transporte 2 (CDT-2) in both cellulose and hemicellulose degradation and utilization in Neurospora crassa. PLoS ONE, v. 9, n. 2, 2014.

CAI, P. et al. The putative cellodextrin transporter-like protein CLP1 is involved in cellulase induction in Neurospora crassa. Journal of Biological Chemistry, v. 290, n. 2, p. 788-796, 2015.

CAMPOS ANTONIÊTO, A. C. et al. Trichoderma reesei CRE1-mediated Carbon Catabolite Repression in Response to Sophorose Through RNA Sequencing Analysis. Current Genomics, v. 17, n. 2, p. 119-131, 2016.

CARLE-URIOSTE, J. C. et al. Cellulase Induction in Trichoderma reesei by Cellulose Requires Its Own Basal Expression *. v. 272, n. 15, p. 10169-10174, 1997.

CARRERAS-VILLASENOR, N.; SANCHEZ-ARREGUIN, J. A.; HERRERA-ESTRELLA, A. H. Trichoderma: sensing the environment for survival and dispersalMicrobiology, 2012.

CASTRO, L. D. S. et al. Expression pattern of cellulolytic and xylanolytic genes regulated by transcriptional factors XYR1 and CRE1 are affected by carbon source in Trichoderma reesei. Gene Expression Patterns, v. 14, n. 2, p. 88-95, 2014. 
Referências

CHAUDHARY, N. et al. Proteome scale census of major facilitator superfamily transporters in Trichoderma reesei using protein sequence and structure based classification enhanced ranking. Gene, v. 585, n. 1, p. 166-176, 2016.

CHURCHWELL, M. I. et al. Improving LC-MS sensitivity through increases in chromatographic performance: Comparisons of UPLC-ES/MS/MS to HPLC-ES/MS/MS. Journal of Chromatography B: Analytical Technologies in the Biomedical and Life Sciences, v. 825, n. 2, p. 134-143, 2005.

COLABARDINI, A. C. et al. Functional characterization of a xylose transporter in Aspergillus nidulans. Biotechnology for biofuels, v. 7, p. 1-19, 2014.

DASHTBAN, M.; SCHRAFT, H.; QIN, W. Fungal bioconversion of lignocellulosic residues; Opportunities \& perspectivesInternational Journal of Biological Sciences, 2009a.

DASHTBAN, M.; SCHRAFT, H.; QIN, W. Fungal bioconversion of lignocellulosic residues; Opportunities \& perspectivesInternational Journal of Biological Sciences, 2009 b.

DIALLINAS, G. Understanding transporter specificity and the discrete appearance of channel-like gating domains in transporters. Frontiers in Pharmacology, v. 5 AUG, n. September, p. 1-17, 2014.

DOS REIS, T. F. et al. Identification and characterization of putative xylose and cellobiose transporters in Aspergillus nidulans. Biotechnology for Biofuels, v. 9, n. 1, p. 204, 2016.

DOS SANTOS CASTRO, L. et al. Comparative metabolism of cellulose, sophorose and glucose in Trichoderma reesei using high-throughput genomic and proteomic analyses. Biotechnology for biofuels, v. 7, n. 1, p. 41, 2014.

DOS SANTOS CASTRO, L. et al. Understanding the Role of the Master Regulator XYR1 in Trichoderma reesei by Global Transcriptional Analysis. Frontiers in Microbiology, v. 7, n. February, p. 1-16, 2016.

EMPRESA DE PESQUISA ENERGÉTICA. Balanço Energético Nacional 2014. Relatório Síntese: Ano base 2013. Empresa de Pesquisa Energética (EPE), p. 54, 2014.

ENG, J. K.; MCCORMACK, A. L.; YATES, J. R. Sequences in a Protein Database. American society for mass spectrometry, v. 5, n. 11, p. 976-989, 1994.

FEKETE, E. et al. Identification of a permease gene involved in lactose utilisation in Aspergillus nidulans. Fungal genetics and biology : FG \& B, v. 49, n. 6, p. 415-25, jun. 2012.

FUJITA, Y. et al. Direct and efficient production of ethanol from cellulosic material with a yeast strain displaying cellulolytic enzymes. Applied and Environmental Microbiology, v. 68, p. 5136-5141, 2002.

FURUKAWA, T. et al. Identification of specific binding sites for XYR1, a transcriptional activator of cellulolytic and xylanolytic genes in Trichoderma reesei. Fungal Genetics and Biology, v. 46, n. 8, p. 564-574, 2009.

GALAZKA, J. M. et al. Cellodextrin transport in yeast for improved biofuel production. 
Science (New York, N.Y.), v. 330, n. 6000, p. 84-86, 1 out. 2010.

GLASS, N. L. et al. Plant cell wall deconstruction by ascomycete fungi. Annual review of microbiology, v. 67, p. 477-98, 2013.

GUO, B. et al. Comparison of catalytic properties of multiple $\beta$-glucosidases of Trichoderma reesei Comparison of catalytic properties of multiple $\beta$-glucosidases of Trichoderma reesei. n. February, 2016.

GUPTA, V. K. et al. The Post-genomic Era of Trichoderma reesei : What $\hat{a} €^{\mathrm{TM}} \mathrm{s}$ Next? Trends in Biotechnology, v. 34, n. 12, p. 970-982, 2016.

HÄKKINEN, M. et al. Re-annotation of the CAZy genes of Trichoderma reesei and transcription in the presence of lignocellulosic substrates. Microbial cell factories, v. 11, p. 134, jan. 2012.

HAMELINCK, C. N.; VAN HOOIJDONK, G.; FAAIJ, A. P. C. Ethanol from lignocellulosic biomass: Techno-economic performance in short-, middle- and long-term. Biomass and Bioenergy, v. 28, n. 4, p. 384-410, 2005.

HEROLD, S. et al. Xylanase gene transcription in Trichoderma reesei is triggered by different inducers representing different hemicellulosic pentose polymers. Eukaryotic Cell, v. 12, n. 3, p. 390-398, 2013.

HUANG, Z. et al. A novel major facilitator transporter TrSTR1 is essential for pentose utilization and involved in xylanase induction in Trichoderma reesei. Biochemical and Biophysical Research Communications, v. 3045, p. 1-7, 2015.

ILMÉN, M. et al. Regulation of cellulase gene expression in the filamentous fungus Trichoderma reesei. Applied and environmental microbiology, v. 63, p. 1298-1306, 1997.

ISIKGOR, F. H.; BECER, C. R. Polymer Chemistry the production of bio-based chemicals and polymers. p. 4497-4559, 2015.

IVANOVA, C. et al. Systems Analysis of Lactose Metabolism in Trichoderma reesei Identifies a Lactose Permease That Is Essential for Cellulase Induction. PLoS ONE, v. 8, 2013.

JUHÁSZ, T. et al. Characterization of cellulases and hemicellulases produced by Trichoderma reesei on various carbon sources. Process Biochemistry, v. 40, p. 3519-3525, 2005 .

KASHO, V. N.; SMIRNOVA, I. N.; KABACK, H. R. Sequence Alignment and Homology Threading Reveals Prokaryotic and Eukaryotic Proteins Similar to Lactose Permease. Journal of Molecular Biology, v. 358, n. 4, p. 1060-1070, 2006.

KROGH, A. et al. Predicting Transmembrane Protein Topology with a Hidden Markov Model : Application to Complete Genomes. 2001.

KUBICEK, C. P. et al. Metabolic engineering strategies for the improvement of cellulase production by Hypocrea jecorina. Biotechnology for biofuels, v. 2, p. 19, 2009.

KUMAR, A.; GAUTAM, A.; DUTT, D. Biotechnological Transformation of Lignocellulosic Biomass in to Industrial Products : An Overview. n. March, p. 149-168, 2016. 
Referências

KYTE, J. et al. A Simple Method for Displaying the Hydropathic Character of a Protein. p. 105-132, 1982.

LAW, C. J.; MALONEY, P. C.; WANG, D.-N. Ins and outs of major facilitator superfamily antiporters. Annual review of microbiology, v. 62, p. 289-305, jan. 2008.

LEITE, D. C. et al. Can Brazil replace $5 \%$ of the 2025 gasoline world demand with ethanol ? Energy, v. 34, p. 655-661, 2009.

MANDELS, M.; REESE, E. T. INDUCTION OF CELLULASE IN FUNGI BY CELLOBIOSE. n. Cx, p. 816-826, 1959.

MARQUES, F. Obstáculos no caminho. Revista Pesquisa Fapesp, p. 58-63, 2018.

MARTINEZ, D. et al. Speaker: TzeFeng-Tian Advisor: Ruey-Shyang, Hseu , PhD Many evidences show the importance of bioethanol y Reduce dependent on imported petroleum y Lower environmental pollution y Cellulosic ethanol offers large reductions in green house gas ( GHG ) emi. p. 553-560, 2008.

MOHD AZHAR, S. H. et al. Yeasts in sustainable bioethanol production: A review. Biochemistry and Biophysics Reports, v. 10, n. November 2016, p. 52-61, 2017.

MUSSATTO, S.; TEIXEIRA, J. Lignocellulose as raw material in fermentation processes. applied Microbiology an Microbial Biotechnology, v. 2, p. 897-907, 2010.

NAKARI-SETÄLÄ, T. et al. Genetic modification of carbon catabolite repression in Trichoderma reesei for improved protein production. Applied and Environmental Microbiology, v. 75, n. 14, p. 4853-4860, 2009.

NOGUEIRA, K. M. V et al. Biotechnology for Biofuels Characterization of a novel sugar transporter involved in sugarcane bagasse degradation in Trichoderma reesei. p. 1-17, 2018.

ORCIUNCULA, J. D. O. P. et al. Identification of Major Facilitator Transporters Involved in Cellulase Production during Lactose Culture of Trichoderma reesei PC-3-7. v. 77, n. 5, p. 1014-1022, 2013.

PAO, S. S.; PAULSEN, I. T.; SAIER, M. H. Major facilitator superfamily. Microbiology and molecular biology reviews : MMBR, v. 62, n. 1, p. 1-34, 1998.

PAULA, R. G. DE et al. Review Article New Genomic Approaches to Enhance Biomass Degradation by the Industrial Fungus Trichoderma reesei. v. 2018, 2018.

PAUL DALY, JOLANDA M. VAN MUNSTER, R. R. AND D. B. A. No Title. In: SILVA, R. N. (Ed.). . Fungal Biothecnology for Biofuel Production. [s.l: s.n.]. p. 82-127.

PAULINO, J. et al. Improvement of Brazilian bioethanol production e Challenges and perspectives on the identi fi cation and genetic modi fi cation of new strains of Saccharomyces cerevisiae yeasts isolated during ethanol process. Fungal Biology, v. 122, n. 6, p. 583-591, 2018.

PETERSON, R.; NEVALAINEN, H. Trichoderma reesei RUT-C30 - Thirty years of strain improvement Review Trichoderma reesei RUT-C30 - thirty years of strain improvement. n. January, 2012.

POLIDORI, E. et al. Hexose uptake in the plant symbiotic ascomycete Tuber borchii 
Vittadini: biochemical features and expression pattern of the transporter TBHXT1. Fungal Genetics and Biology, v. 44, n. 3, p. 187-198, 2007.

PORCIUNCULA, J. DE O. et al. Identification of Major Facilitator Transporters Involved in Cellulase Production during Lactose Culture of Trichoderma reesei PC-3-7. Bioscience, Biotechnology, and Biochemistry, v. 77, n. 5, p. 1014-1022, 2013.

PORTNOY, T. et al. Differential regulation of the cellulase transcription factors XYR1, ACE2, and ACE1 in trichoderma reesei strains producing high and low levels of cellulase. Eukaryotic Cell, v. 10, p. 262-271, 2011.

QUINLAN, R. J. et al. Insights into the oxidative degradation of cellulose by a copper metalloenzyme that exploits biomass components. Proceedings of the National Academy of Sciences of the United States of America, v. 108, p. 15079-15084, 2011.

QUISTGAARD, E. M. et al. Understanding transport by the major facilitator superfamily (MFS): structures pave the way. Nature Reviews Molecular Cell Biology, v. 17, n. 2, p. 123-132, 2016.

RALPH, J. et al. Variability in Lignin Composition and Structure in Cell Walls of Di ff erent Parts of Macau' ba ( Acrocomia aculeata ) Palm Fruit'. 2018.

REIS, T. F. DOS et al. Identification of glucose transporters in aspergillus nidulans. PLoS ONE, v. 8, n. 11, p. 1-15, 2013.

RIES, L. et al. Genome-wide transcriptional response of Trichoderma reesei to lignocellulose using RNA sequencing and comparison with Aspergillus niger. BMC Genomics, v. 14, p. $541,2013 \mathrm{a}$.

RIES, L. et al. Genome-wide transcriptional response of Trichoderma reesei to lignocellulose using RNA sequencing and comparison with Aspergillus niger. p. 1-12, $2013 \mathrm{~b}$.

ROMANÍ, A. et al. Bioresource Technology Metabolic engineering of Saccharomyces cerevisiae ethanol strains PE-2 and CAT-1 for efficient lignocellulosic fermentation. v. 179, p. $150-158,2015$.

SAHA, B. C. Hemicellulose bioconversion. Journal of industrial microbiology \& biotechnology, v. 30, n. 5, p. 279-91, maio 2003.

SAINI, J. K.; SAINI, R.; TEWARI, L. Lignocellulosic agriculture wastes as biomass feedstocks for second-generation bioethanol production: concepts and recent developments. 3

Biotech, v. 5, n. 4, p. 337-353, 2015.

SCHELLER, H. V.; ULVSKOV, P. Hemicelluloses. Annual Review of Plant Biology, v. 61, n. 1, p. 263-289, 2010.

SCHMOLL, M. et al. The G-alpha protein GNA3 of Hypocrea jecorina (anamorph Trichoderma reesei) regulates cellulase gene expression in the presence of light. Eukaryotic Cell, v. 8, n. 3, p. 410-420, 2009.

SCHMOLL, M.; KUBICEK, C. P. Regulation of Trichoderma cellulase formation: lessons in molecular biology from an industrial fungus. A review. Acta microbiologica et immunologica Hungarica, v. 50, p. 125-145, 2003.

SCHMOLL, M.; SCHUSTER, A. Biology and biotechnology of TrichodermaApplied 
Microbiology and Biotechnology, 2010.

SCHUSTER, A. et al. A versatile toolkit for high throughput functional genomics with Trichoderma reesei. Biotechnology for biofuels, v. 5, p. 1-10, 2012.

SEDLAK, M.; HO, N. W. Y. Characterization of the effectiveness of hexose transporters for transporting xylose during glucose and xylose co-fermentation by a recombinant Saccharomyces yeast. p. 671-684, 2004.

SEIBOTH, B.; IVANOVA, C.; SEIDL-SEIBOTH, V. Trichoderma reesei: A Fungal Enzyme Producer for Cellulosic Biofuels. Biofuel Production-Recent Developments and Prospects, 2011.

SLOOTHAAK, J. et al. Aspergillus niger membrane-associated proteome analysis for the identification of glucose transporters. Biotechnology for biofuels, v. 8, p. 150, 2015.

SLOOTHAAK, J. et al. Biotechnology for Biofuels Identification and functional characterization of novel xylose transporters from the cell factories Aspergillus niger and Trichoderma reesei. Biotechnology for biofuels, v. 9, n. 148, p. 1-15, $2016 \mathrm{a}$.

SLOOTHAAK, J. et al. Identification of a Novel L-rhamnose Uptake Transporter in the Filamentous Fungus Aspergillus niger. PLoS Genetics, v. 12, n. 12, p. 1-27, 2016b.

SONNHAMMER, E. L. L.; VON HEIJNE, G.; KROGH, A. A hidden Markov model for predicting transmembrane helices in protein sequences. Proceedings, v. 6, p. 175-182, 1998.

STERNBERG, D.; MANDELS, G. R. Induction of cellulolytic enzymes in Trichoderma reesei by sophorose. Journal of Bacteriology, v. 139, n. 3, p. 761-769, 1979a.

STERNBERG, D.; MANDELS, G. R. Induction of Cellulolytic Enzymes in Trichoderma reesei by Sophorose. v. 139, n. 3, p. 761-769, 1979 b.

TV, M. M.; TELEMAN, A. Action of Trichoderma reesei mannanase on galactoglucomannan in pine kraft pulp. v. 57, p. 191-204, 1997.

TYANOVA, S. et al. The Perseus computational platform for comprehensive analysis of (prote)omics data. Nature Methods, v. 13, n. 9, p. 731-740, 2016.

TYANOVA, S.; TEMU, T.; COX, J. The MaxQuant computational platform for mass spectrometry-based shotgun proteomics. Nature Protocols, v. 11, n. 12, p. 2301-2319, 2016.

UNCOUPLES, C. C.; SENSING, E. G. crossm Cellobiose Consumption Uncouples Extracellular Glucose Sensing and Glucose Metabolism in Saccharomyces. v. 8, n. 4, p. 1-12, 2017.

WIECZORKE, R. et al. Concurrent knock-out of at least 20 transporter genes is required to block uptake of hexoses in Saccharomyces cerevisiae. FEBS Letters, v. 464, n. 3, p. $123-$ 128, 1999.

YAMAMOTO, T. et al. Cellodextrin Transport in Yeast for. n. October, p. 801-804, 2010.

YANG, J. M. Development and evaluation of a generic evolutionary method for proteinligand docking. Journal of Computational Chemistry, v. 25, n. 6, p. 843-857, 2004.

YANG, J. M.; CHEN, C. C. GEMDOCK: A Generic Evolutionary Method for Molecular Docking. Proteins: Structure, Function and Genetics, v. 55, n. 2, p. 288-304, 2004. 
Referências

ZABED, H. et al. Fuel ethanol production from lignocellulosic biomass: An overview on feedstocks and technological approaches. Renewable and Sustainable Energy Reviews, v. 66, p. 751-774, 2016.

ZABED, H. et al. Bioethanol production from renewable sources: Current perspectives and technological progress. Renewable and Sustainable Energy Reviews, v. 71, n. October 2015, p. 1-27, 2017.

ZHANG, W. et al. Two Major Facilitator Superfamily Sugar Transporters from Trichoderma reesei and Their Roles in Induction of Cellulase. v. 288, n. 46, p. 32861-32872, 2013.

ZHANG, W. et al. Identification of residues important for substrate uptake in a glucose transporter from the filamentous fungus Trichoderma reesei. Scientific Reports, v. 5, n. 27, p. $1-10,2015$.

ZNAMEROSKI, E. A. et al. Evidence for Transceptor Function of Cellodextrin Transporters in Neurospora crassa *. v. 289, n. 5, p. 2610-2619, 2014.

ZNAMEROSKI, E. A; GLASS, N. L. Using a model filamentous fungus to unravel mechanisms of lignocellulose deconstruction. Biotechnology for biofuels, v. 6, n. 1, p. 6, jan. 2013. 
Apêndices

\section{Apêndices}

\section{Apêndices referente ao capítulo I.}

Additional file 1. Strains and plasmids used in this work.

\begin{tabular}{|c|c|}
\hline Strains/plasmids & Genotype \\
\hline \multicolumn{2}{|l|}{ S. cerevisae } \\
\hline \multirow[t]{3}{*}{ BY.VW4000 } & CEN.PK2-1C hxt134::loxP hxt154::loxP hxt164::IoxP hxt144::IoxP hxt124::loxP \\
\hline & hxt94::loxP hxt114::IoxP hxt104::loxP hxt84::IoxP hxt5144::loxP hxt24::IoxP \\
\hline & 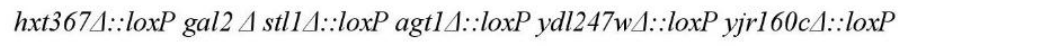 \\
\hline SC9721 & MATa his 3-D200 URA 3-52 leu2D1 lys 2D202 trp 1D63 \\
\hline EBY.VW4000 & EBYVW4000 pRH195 pRH274pGH1 \\
\hline \multicolumn{2}{|l|}{+ pRH195m } \\
\hline \multicolumn{2}{|l|}{+ pRH274+pGH1 } \\
\hline $\operatorname{Tr} 69957:: \mathrm{GFP}::$ & EBYVW4000 pRH195 hxtB pRH274 \\
\hline \multicolumn{2}{|l|}{ EBY.VW4000 } \\
\hline \multicolumn{2}{|l|}{ T. reesei } \\
\hline QM6A & $\Delta t m u s 53 \Delta P y r 4$ \\
\hline$\Delta 69957$ & $\Delta t m u s 53 \Delta P y r 4 \Delta 69957$ \\
\hline \multicolumn{2}{|l|}{ Plasmids } \\
\hline pRH195 & pBluescript II SK+, TRP1, CEN6, ARSH4+PHXT7-XKS1-THXT7 \\
\hline \multirow[t]{2}{*}{ pRH274 } & pBluescript II SK+, URA3, CEN6, ARSH4 + PPGK1-XYL1-TPGK1; PADH1-XYL2-TADH1; \\
\hline & PHXT7-XKS1-ТHXT7 \\
\hline pGH1 & pRS425 PGKlp-ghl-1-CYClt \\
\hline
\end{tabular}


Apêndices

Additional file 2. Oligonucleotides used for $\operatorname{pyr} G$ amplification, promoter region and terminator region of 69957

\begin{tabular}{ll}
\hline Oligonucleotides & Sequences \\
\hline Tr69957_pRS426_5fw & 5'GTAACGCCAGGGTTTTCCCAGTCACGACGGTGCTCAAGACATCCTAGGTATG-3' \\
Tr69957_pyrG_5rv & 5'-CAGTGCCTCCTCTCAGACAGAATAGCAGTAGCGAAGTAGAGGCTGC-3' \\
Tr69957_pyrG_3fw & 5'-GAGCATTGTTTGAGGCGAATTCAACCCACTTGACACCGTTGCCGG-3' \\
Tr69957_pRS426_3rv & 5'-GCGGTTAACAATTTCTCTCTGGAAACAGCGCATCTGGGTGGTCGAGTAACG-3' \\
pyrG_rv & 5'-GCAGCCTCTACTTCGCTACTGCTATTCTGTCTGAGAGGAGGCACTG-3' \\
pyrG_fw & 5'-GAGCATTGTTTGAGGCGAATTCAACCCACTTGACACCGTTGCCGG-3' \\
\hline
\end{tabular}


A

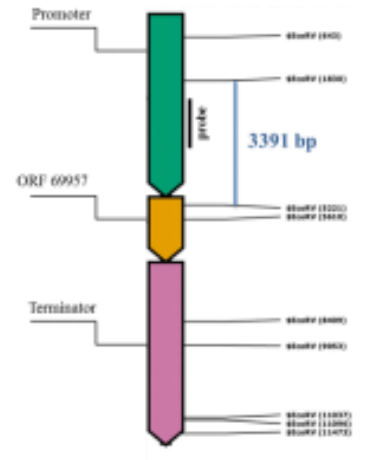

QM6A
B

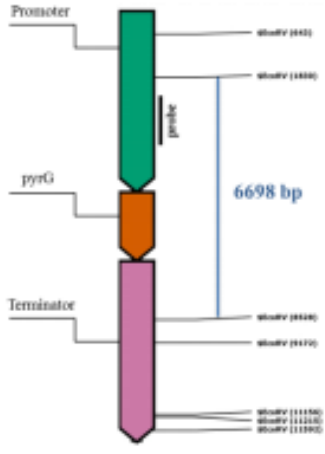

$\Delta 69957$

Additional file 3. Southern blot analyse to confirm deletion of $\operatorname{Tr} 69957$ in $T$. reesei. (A) Strategy used to confirm deletion of $\operatorname{Tr} 69957$ by Southern blot. The figure shows the promoter region (in green) and terminator (in purple) of the gene, with the substitution of the ORF by the pyrG selection marker. A specific DNA probe was created in order to bind the portion of the gene (in blue), confirming its presence in the analyzed genetic content. (B) Southern blot showing the parental fungus (QM6a $\Delta$ tmus $53 \Delta$ pyr4) used as control and four deleted candidates that did not present detection of the gene portion equivalent to $3391 \mathrm{bp}$ as in the parental and presented the region corresponding to $6698 \mathrm{bp}$, confirming the deletion. 
Apêndices

Additional file 4. Oligonucleotides used for evaluation of gene expression

\begin{tabular}{|c|c|}
\hline Oligonucleotides & Sequences \\
\hline$c e l 7 a \mathrm{~F}$ & 5' ACAAGAATGCATCGTCTCCG 3' \\
\hline$c e l 7 a \mathrm{R}$ & 5'TGTTCCACCCGTTGTAGTTG 3' \\
\hline cel6a $\mathrm{F}$ & 5' CCGAGCTTGGTAGTTACTCTG 3' \\
\hline cel6a $\mathrm{R}$ & 5' GGTAGCCTTCTTGACTGAGT 3' \\
\hline xynl F & 5'GGC CAA ATT ATC GTC AAC TGT C 3' \\
\hline xynl $R$ & 5'TCT GTC TTT TGG GCT TGG AG 3' \\
\hline cel3a F & 5' CTG TAC ATC ACC TAC CCA TC3' \\
\hline cel3a $\mathbf{R}$ & 5' TAG CTG AGA TCT CGT CGT C3' \\
\hline cella $\mathbf{F}$ & 5' TTT GCC TGG TCG CTC ATG3' \\
\hline cella $\mathbf{R}$ & 5' AAT CAG CTC GTC AAA CAG CG3' \\
\hline $69957 \mathrm{~F}$ & 5' CTC TTA CAG TTG GCC CTA TCA C 3' \\
\hline $69957 \mathrm{R}$ & 5' GGT CGG GTT CAT AAA GTA CGG $3^{\prime}$ \\
\hline xyn2 F & 5' TGT CAA CGA GCC TTC CAT C 3 ' \\
\hline xyn2 R & 5' TCT GCA CAG TAA CAG TTC CG 3' \\
\hline
\end{tabular}


Apêndices

Additional file 5. Oligonucleotides used for complementation in S. cerevisiae.

\begin{tabular}{ll}
\hline Oligonucleotides & Sequences \\
\hline pRH195_AN69957 START & 5' GTTTTTTTAA TTTTAATCAA AATGGCGGAG GTCAACATC 3' \\
ORF69957_SS_GFP & 5' AGTTCTTCTCCTTTACTCATTCCCCGTGTTCCAGAA GAGG3' \\
pRH195 GFP_CS_F- yeast & 5' GAATTAATAAAAGTGTTCGCTTAACGCCAAGCTTGCATGC 3' \\
spacerGFP 5'R_pRH195-yeast & 5'GGAACACGGG GA ATGAGTAA AGGAGAAGAA CTTTTCACTG G 3' \\
69957-5F & 5' GGGGGGATCCCTTTCGGAGGAACAAGTA 3' \\
69957 -3R & 5'GGGG ACTAGTTGTTTTCTCTCTGCCAGTTG 3' \\
\hline
\end{tabular}


13068_2018_1084_MOESM6_ESM.txt Additional file 6._SCORING FUNCTIONS: the global accuracy for the five designed candidates. The chosen structure was the Model 1, which was predicted based on the 4ZWB.A (human GLUT3 glucose transporter (N45T mutant) with bound D-glucose, outward-occluded conformation), determined by Deng et al. [39], since it presents not only the highest value for C-score, but also satisfactory values for the TM-score and the RMSD, also being the largest cluster. C-score: the confidence of the construction essentially based on the template alignments and the parameters for assembling the structure, whereas the higher the value, the higher the confidence and quality. TM-Score and RMSD: the similarity between the designed model and the template used, being less and more sensitive to local error, respectively. TM-score > 0.5 indicates a correct topology. Number of decoys: the amount of conformations generated by the software. Cluster density: the size of the clusters formed for each model, whereas the larger the cluster, the lowest the free energy of the model.

13068_2018_1084_MOESM7_ESM.txt Additional file 7._LOCAL ACCURACY: the divergence of the modeling represented by the distance $(\AA)$ between the protein designed and the template used for the construction of it. RES: residue number; SS: predicted secondary structure (C: random coil, $\mathrm{H}$ : alpha-helix, $\mathrm{S}$ : beta-strand; SA: predicted solvent accessibility at 25\% cutoff (E: exposed, B: buried); COV: alignment coverage; BFP: predicted normalized Bfactor; RSQ_1: Residue-Specific Quality of the template (the estimated deviation of the residue on the template from the built protein)).

13068_2018_1084_MOESM8_ESM.txt Additional file 8. INTERACTION PROFILE: the detailed amount of energy required for each atom in the protein to interact with each one of the ligands, through hydrogen bonding $(\mathrm{H})$ and Van der Waals contact (V). 


\section{Apêndices referente ao capítulo III}

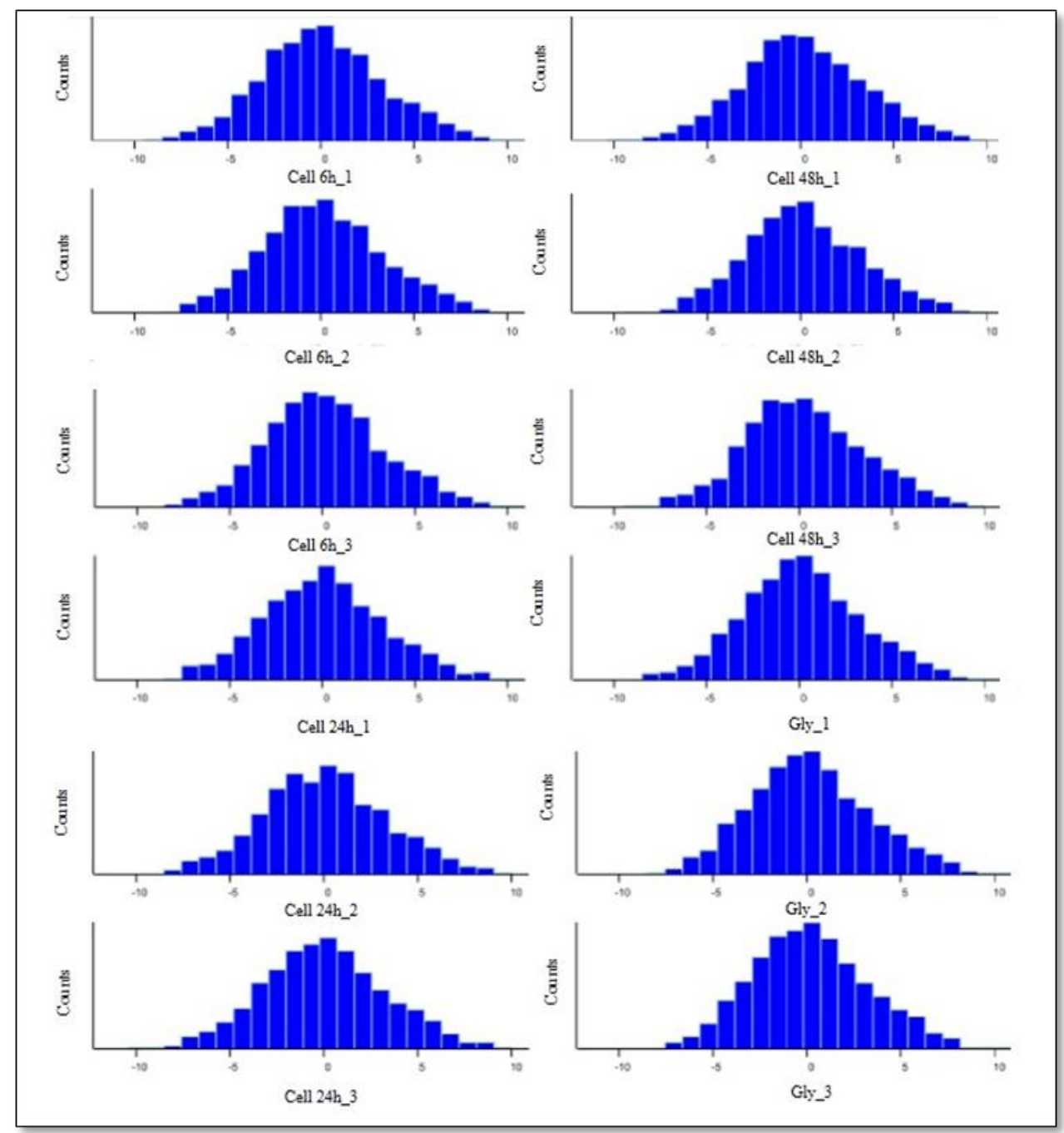

Additional file 1. The overall ratio distributions of all samples; The log ratios of each sample are separately represented as histograms. 


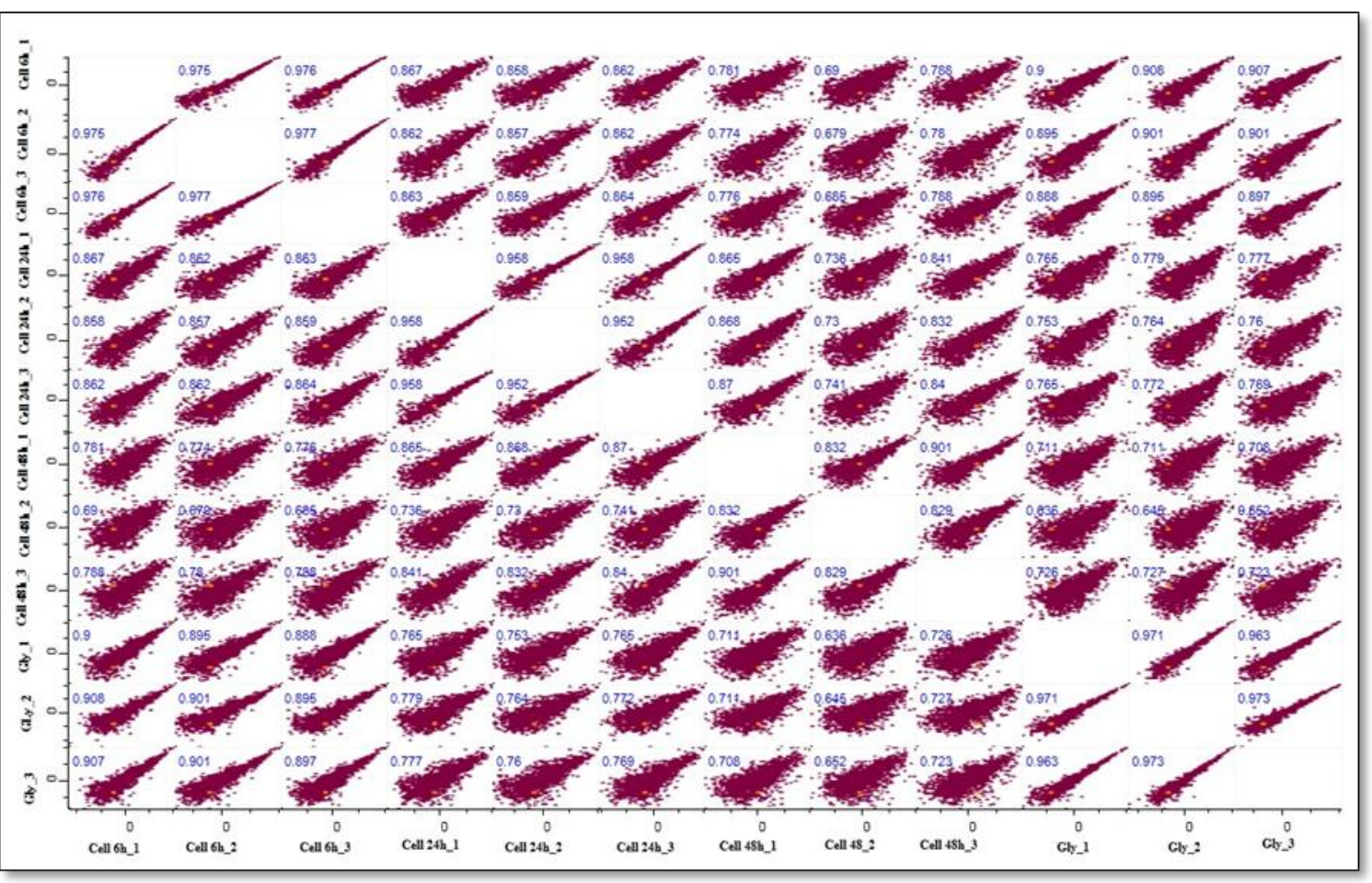

Additional file 2. Pearson correlation between the biological replicates samples corresponding to Trichoderma reesei culture in cellulose (cell) or glycerol (Gly) during 6, 24 and 48 hours. 


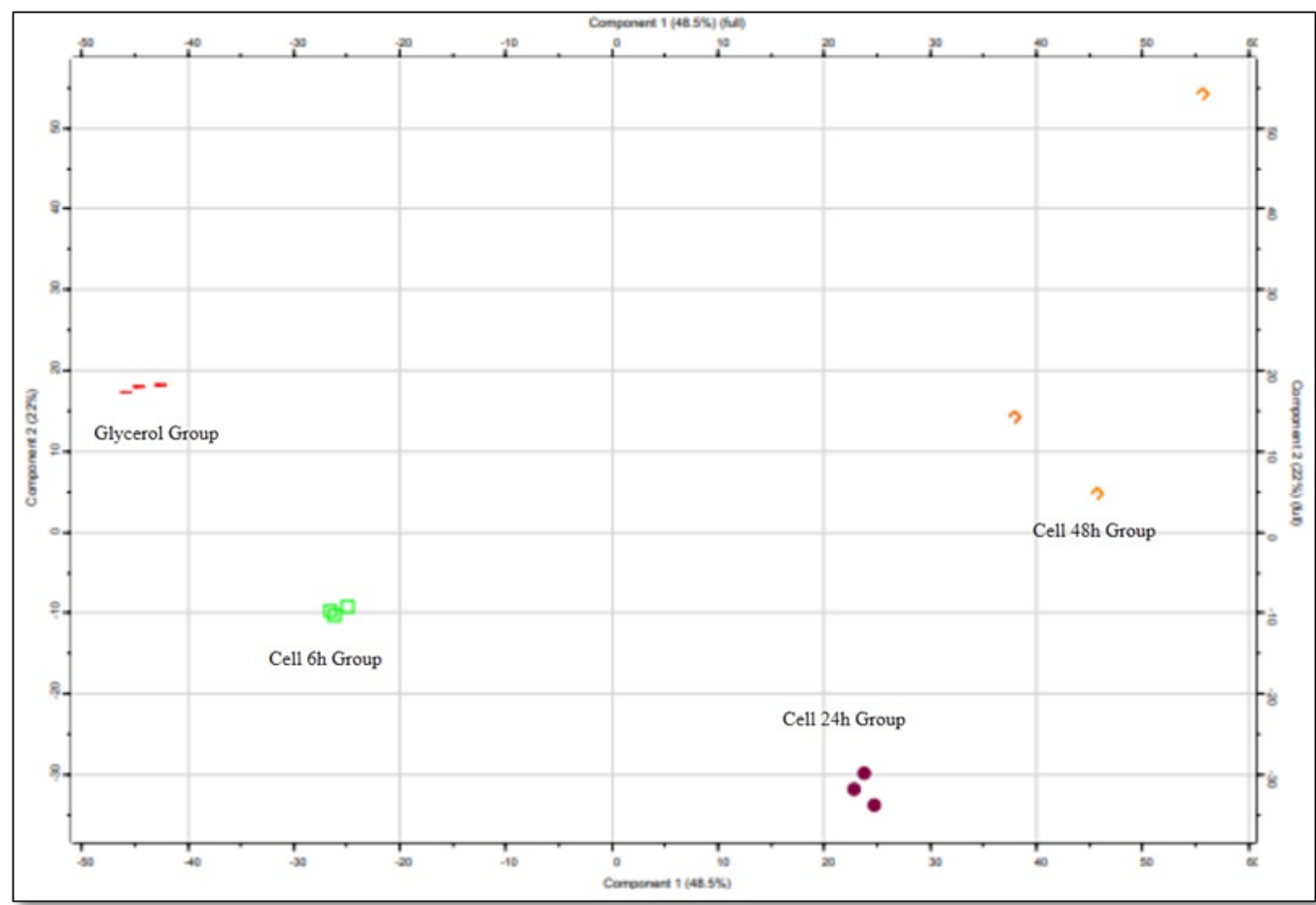

Additional file 3. Principal Component Analysis (PCA) for the four group of samples analyzed. 
ANEXO DE PUBLICAÇÕES 
Anexo de publicações

\section{Anexo de publicações}

1) Karoline MV Nogueira, Renato Graciano de Paula, Amanda Cristina Campos Antoniêto, Thaila F Reis, Cláudia Batista Carraro, Alinne Costa Silva, Fausto Almeida, Carem Gledes Vargas Rechia, Gustavo H Goldman, Roberto N Silva (2018). Characterization of a novel sugar transporter involved in sugarcane bagasse degradation in Trichoderma reesei. Biotechnology for biofuels $11(1), 84$.

2) Renato Graciano de Paula, Amanda Cristina Campos Antoniêto, Liliane Fraga Costa Ribeiro, Cláudia Batista Carraro, Karoline Maria Vieira Nogueira, Douglas Christian Borges Lopes, Alinne Costa Silva, Mariana Taíse Zerbini, Wellington Ramos Pedersoli, Mariana do Nascimento Costa, Roberto Nascimento Silva (2018). New Genomic Approaches to Enhance Biomass Degradation by the Industrial Fungus Trichoderma reesei. International Journal of Genomics, vol. 2018.

3) Amanda Cristina Campos Antoniêto, Wellington Ramos Pedersoli, Lílian dos Santos Castro, Rodrigo da Silva Santos, Aline Helena da Silva Cruz, Karoline Maria Vieira Nogueira, Rafael Silva-Rocha, Antonio Rossi, Roberto Nascimento Silva (2017). Deletion of $\mathrm{pH}$ regulator pac-3 affects cellulase and xylanase activity during sugarcane bagasse degradation by Neurospora crassa. PloS one 12 (1), e0169796.

4) Amanda Cristina Campos Antonieto, Karoline Maria Vieira Nogueira, Renato Graciano de Paula, Maria-Eugenia Guazzaroni, Luísa Czamanski Nora, Fausto Bruno dos Reis Almeida, Thiago Aparecido da Silva Gustavo Henrique Goldman, Roberto Nascimento Silva and Rafael Silva-Rocha. A novel Cys2His2 zinc-finger homolog of AZF1 modulates holocellulase expression in Trichoderma reesei. Submitted to Nature Communications. 